ENVIRONMENTAL RESTORATION PROGRAM

\title{
Waste Area Grouping 2 Phase I Task Data Report: Human Health Risk Assessment
}

ORNL/ER-368

\section{RECEIVED AUG 20 Tि96 OSTI}

This document has been approved by the ORNL Technical Information Office for release to the public. Date: $7-1-96$

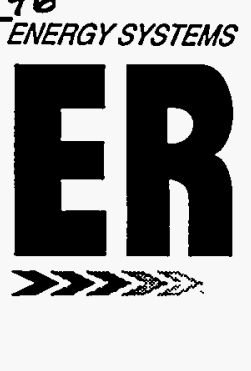


This report has been reproduced directly from the best available copy.

Available to DOE and DOE contractors from the Office of Scientific and Technical Information, P.O. Box 62, Oak Ridge, TN 37831; prices available from 423-576-8401 (fax 423-576-2865).

Available to the public from the National Technical Information Service, U.S. Department of Commerce, 5285 Port Royal Rd., Springfield, VA 22161. 
Energy Systems Environmental Restoration Program

Waste Area Grouping 2 Phase I

Task Data Report: Human Health

Risk Assessment

S. T. Purucker

D. M. Douthat

Date Issued-June 1996

\author{
Prepared by \\ Risk Analysis Section \\ Health Sciences Research Division \\ Oak Ridge National Laboratory \\ Oak Ridge, Tennessee 37831
}

Prepared for the

U.S. Department of Energy

Office of Environmental Management under budget and reporting code EW 20

Environmental Management Activities at the OAK RIDGE NATIONAL LABORATORY

Oak Ridge, Tennessee 37831 managed by

LOCKHEED MARTIN ENERGY SYSTEMS, INC.

for the

U.S. DEPARTMENT OF ENERGY

under contract DE-AC05-84OR21400 


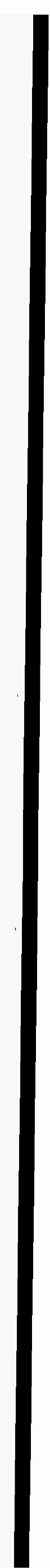




\section{ACKNOWLEDGMENTS}

Special thanks to Leslie Bloom and Yeeming Leong for risk database and mapping support, Anthony Armstrong, Roger Clapp, Martin Clauberg, Elizabeth Etnier, Craig Rightmire, and Mark Tardiff for their advice and constructive comments in the technical review of this document, and Beth Ladd for her assistance in the preparation of this document. 


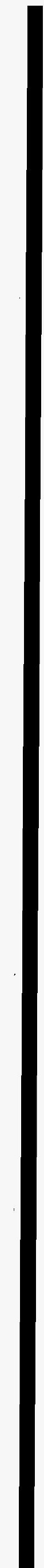




\section{DISCLAIMER}

Portions of this document may be illegible in electronic image products. Images are produced from the best available original document. 


\section{DISCLAIMER}

This report was prepared as an account of work sponsored by an agency of the United States Government. Neither the United States Government nor any agency thereof, nor any of their employees, makes any warranty, express or implied, or assumes any legal liability or responsibility for the accuracy, completeness, or usefulness of any information, apparatus, product, or process disclosed, or represents that its use would not infringe privately owned rights. Reference herein to any specific commercial product, process, or service by trade name, trademark, manufacturer, or otherwise does not necessarily constitute or imply its endorsement, recommendation, or favoring by the United States Government or any agency thereof. The views and opinions of authors expressed herein do not necessarily state or reflect those of the United States Government or any agency thereof. 


\section{PREFACE}

This Waste Area Grouping 2 Phase I Task Data Report: Human Health Risk Assessment report (ORNL/ER-368) was prepared in accordance with requirements of the Comprehensive Environmental Response, Compensation, and Liability Act and using guidelines presented in the United States Environmental Protection Agency's Risk Assessment Guidance for Superfund (EPA 1989). This work was performed under Work Breakdown Structure 1.4.12.6.1.02.40.08.03 (Activity Data Sheet 3326). This report is one of five reports issued in 1996 that provide follow-up information to the Phase I Remedial Investigation (RI) Report for Waste Area Grouping (WAG) 2 at Oak Ridge National Laboratory (ORNL). The five reports address areas of concern that could cause potential human health risk and ecological risk within WAG 2 at ORNL. The purpose of this report is to present a summary of the human health risk assessment results based on the data collected for the WAG 2 Phase I RI. Estimates of risk are provided based on measured concentrations in the surface water, floodplain soil, and sediment of White Oak Creek, Melton Branch, and their tributaries. 


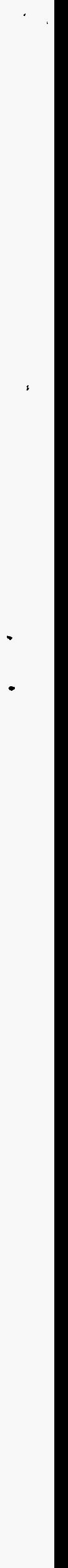




\section{CONTENTS}

ACKNOWLEDGMENTS $\ldots \ldots \ldots \ldots \ldots \ldots \ldots \ldots \ldots \ldots \ldots \ldots \ldots \ldots \ldots \ldots \ldots \ldots$

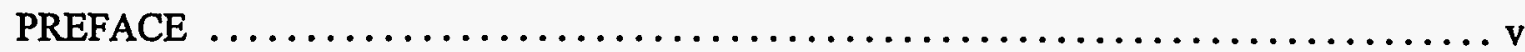

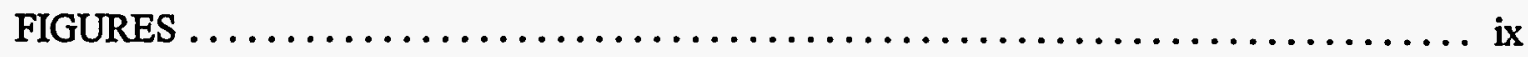

TABLES $\ldots \ldots \ldots \ldots \ldots \ldots \ldots \ldots \ldots \ldots \ldots \ldots \ldots \ldots \ldots \ldots \ldots \ldots \ldots \ldots \ldots \ldots \ldots \ldots \ldots$

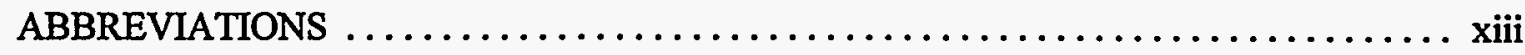

EXECUTTVE SUMMARY $\ldots \ldots \ldots \ldots \ldots \ldots \ldots \ldots \ldots \ldots \ldots \ldots \ldots \ldots \ldots \ldots \ldots \ldots \ldots$

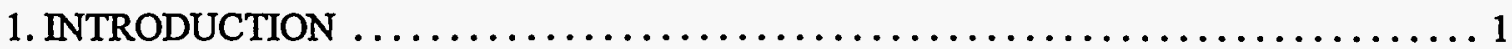

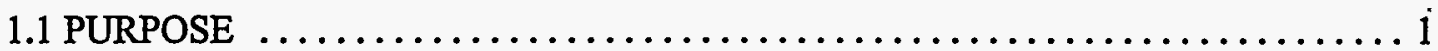

1.2 BACKGROUND $\ldots \ldots \ldots \ldots \ldots \ldots \ldots \ldots \ldots \ldots \ldots \ldots \ldots \ldots \ldots \ldots \ldots \ldots \ldots \ldots \ldots \ldots \ldots$

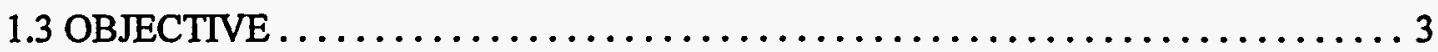

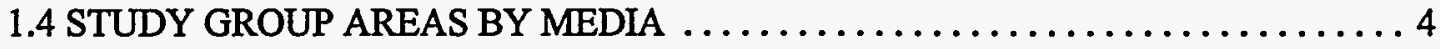

1.5 RISK EXPOSURE SCENARIOS $\ldots \ldots \ldots \ldots \ldots \ldots \ldots \ldots \ldots \ldots \ldots \ldots \ldots \ldots \ldots \ldots \ldots \ldots \ldots \ldots \ldots$

2. IDENTIFICATION OF CHEMICALS OF POTENTIAL CONCERN $\ldots \ldots \ldots \ldots \ldots \ldots \ldots 7$

2.1 GENERAL DATA COLLECTION CONSIDERATIONS $\ldots \ldots \ldots \ldots \ldots \ldots \ldots \ldots 7$

2.2 GENERAL DATA EVALUATION CONSIDERATIONS $\ldots \ldots \ldots \ldots \ldots \ldots \ldots \ldots 7$

2.3 DATA EVALUATION/PREPARATION $\ldots \ldots \ldots \ldots \ldots \ldots \ldots \ldots \ldots \ldots \ldots \ldots$

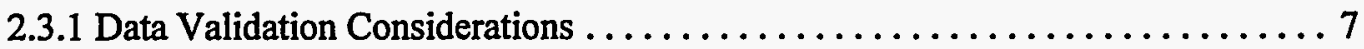

2.3.2 Determination of Chemicals of Potential Concern $\ldots \ldots \ldots \ldots \ldots \ldots \ldots$

2.3.3 Comparison with Background Data ...................... 11

2.3.4 Summary of Essential Nutrients and Residential Preliminary

Remediation Goal Screening $\ldots \ldots \ldots \ldots \ldots \ldots \ldots \ldots \ldots \ldots \ldots \ldots \ldots \ldots$

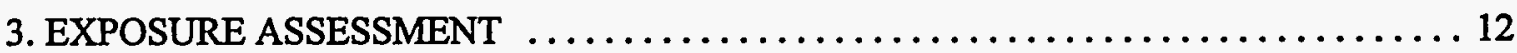

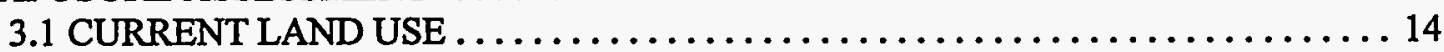

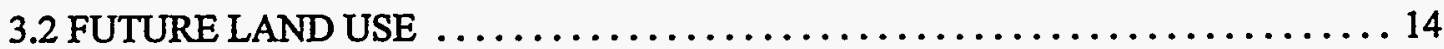

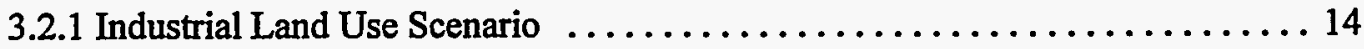

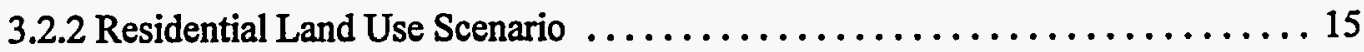

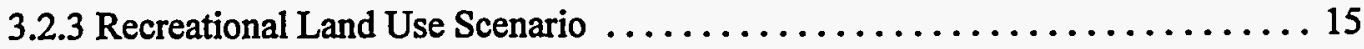

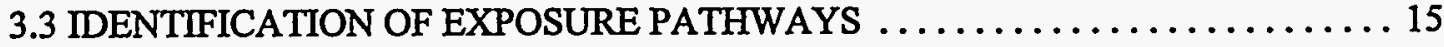

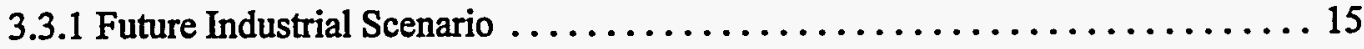

3.3.2 Future Residential Scenario . . . . . . . . . . . . . . . . . . . 16

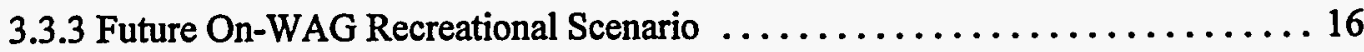

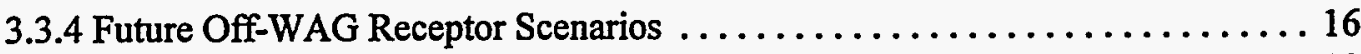

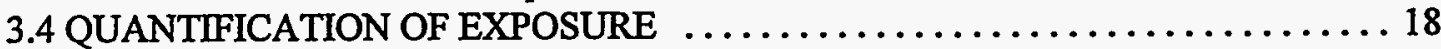

3.4.1 CDI Calculations for the Industrial Land Use Scenario . . . . . . . . . . 18

3.4.2 Chronic Daily Intake Calculations for the Residential Land Use Scenario . . . . 18

3.4.3 Chronic Daily Intake Calculations for the Recreational Land Use Scenario . . . 38

3.4.4 Derivation of Exposure Concentration $\ldots \ldots \ldots \ldots \ldots \ldots \ldots \ldots \ldots \ldots$ 


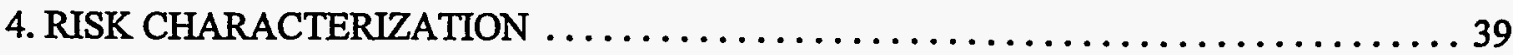

4.1 EVALUATION OF CARCINOGENS AND NONCARCINOGENS $\ldots \ldots \ldots \ldots \ldots \ldots .39$

4.2 RISK SUMMARY BY MEDIA $\ldots \ldots \ldots \ldots \ldots \ldots \ldots \ldots \ldots \ldots \ldots \ldots \ldots, 41$

4.2.1 Sediment/Floodplain Soil $\ldots \ldots \ldots \ldots \ldots \ldots \ldots \ldots \ldots \ldots \ldots \ldots, 41$

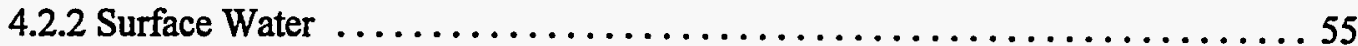

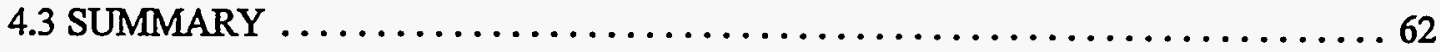

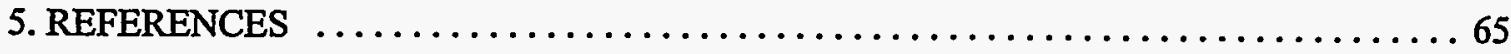

APPENDIX A CARCINOGENIC RISK TABLES FOR THE SEDIMENT IN FLOODPLAIN SOIL DATA USED IN THE WAG 2

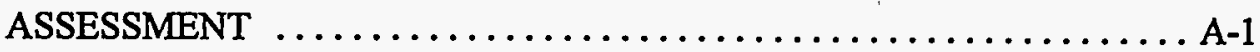

APPENDIX B NONCARCINOGENIC HAZARD QUOTIENT TABLES FOR THE SEDIMENT IN FLOODPLAIN SOIL DATA USED IN THE WAG 2 ASSESSMENT $\ldots \ldots \ldots \ldots \ldots \ldots \ldots \ldots \ldots \ldots$ B -1

APPENDIX C CARCINOGENIC RISK TABLES FOR THE TRIBUTARIES DATA USED IN THE WAG 2 ASSESSMENT $\ldots \ldots \ldots \ldots \ldots \ldots \ldots . . \ldots \ldots$

APPENDIX D NONCARCINOGENIC HAZARD QUOTIENT TABLES FOR THE TRIBUTARIES DATA USED IN THE WAG 2 ASSESSMENT $\ldots \ldots \ldots \ldots \ldots \ldots \ldots \ldots \ldots \ldots$ D- 1

APPENDIX E CARCINOGENIC RISK TABLES FOR THE SEEPS TASK DATA USED IN THE WAG 2 ASSESSMENT $\ldots \ldots \ldots \ldots \ldots \ldots \ldots$ E- 1

APPENDIX F NONCARCINOGENIC HAZARD TABLES FOR THE SEEPS TASK DATA USED IN THE WAG 2 ASSESSMENT $\ldots \ldots \ldots \ldots \ldots \ldots$ F-1

APPENDIX G SURFACE WATER RISK RESULT COMPARISON FOR ${ }^{90} \mathrm{Sr}$ DATA WITH CHAIN-OF-CUSTODY PROBLEMS ......... G-1 


\section{FIGURES}

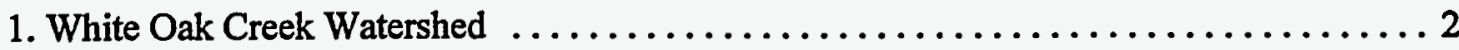

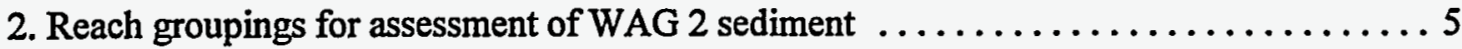

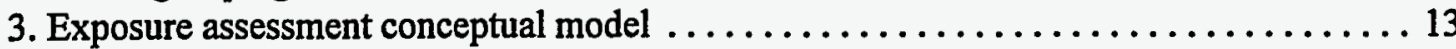

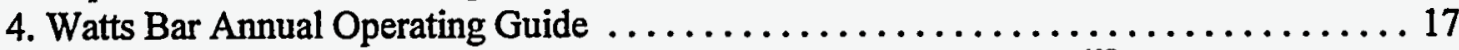

5. Floodplain soil and sediment industrial carcinogenic risk ranges for ${ }^{137} \mathrm{Cs} \ldots \ldots \ldots \ldots 47$

6. Floodplain soil and sediment industrial carcinogenic risk ranges for ${ }^{60} \mathrm{Co} \ldots \ldots \ldots \ldots 48$

7. Floodplain soil and sediment industrial carcinogenic risk ranges for No-Gamma . . . . 49

8. Incremental cancer risk from dredging scenario-Clinch River $\ldots \ldots \ldots \ldots \ldots \ldots 56$

9. Surface water total carcinogenic risk ranges: residential scenario $\ldots \ldots \ldots \ldots \ldots \ldots 58$

10. Surface water carcinogenic risk ranges for ${ }^{90} \mathrm{Sr}$ : residential scenario $\ldots \ldots \ldots \ldots \ldots \ldots$

11. Surface water carcinogenic risk ranges for tritium: residential scenario $\ldots \ldots \ldots \ldots \ldots 60$

12. Surface water total carcinogenic risk ranges: recreational (no fish) scenario $\ldots \ldots \ldots \ldots 61$

13. Surface water noncarcinogenic hazard indexes: residential scenario . . . . . . . . . 63

14. Surface water noncarcinogenic hazard indexes: recreational (no fish) scenario . . . . 64 



\section{TABLES}

1. COPCs for floodplain soil and sediment $\ldots \ldots \ldots \ldots \ldots \ldots \ldots \ldots \ldots \ldots \ldots \ldots \ldots, \ldots \ldots \ldots, 10$

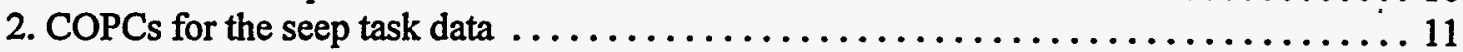

3. On-site industrial exposure scenario (incidental ingestion of soil or sediment pathway) . . 19

4. On-site industrial exposure scenario (dermal contact with soil or sediment pathway) $\ldots .20$

5. On-site industrial exposure scenario (inhalation of soil or sediment pathway) $\ldots \ldots \ldots 21$

6. On-site industrial exposure scenario (external exposure pathway) $\ldots \ldots \ldots \ldots \ldots \ldots 22$

7. On-site residential exposure scenario (ingestion of soil or sediment pathway) $\ldots \ldots \ldots 23$

8. On-site residential exposure scenario (dermal contact with soil or sediment) $\ldots \ldots \ldots 24$

9. On-site residential exposure scenario (inhalation of soil or sediment) $\ldots \ldots \ldots \ldots \ldots 25$

10. On-site residential exposure scenario (external exposure to soil) $\ldots \ldots \ldots \ldots \ldots \ldots 26$

11. On-site residential exposure scenario (ingestion of homegrown produce pathway) $\ldots \ldots 27$

12. On-site residential exposure scenario (ingestion of surface water or groundwater pathway) $\ldots \ldots \ldots \ldots \ldots \ldots \ldots \ldots \ldots \ldots \ldots \ldots \ldots \ldots \ldots \ldots \ldots \ldots \ldots \ldots \ldots \ldots, 28$

13. On-site residential exposure scenario (dermal contact with surface water

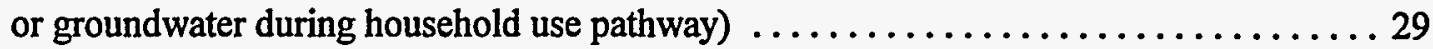

14. On-site residential exposure scenario (inhalation of surface water

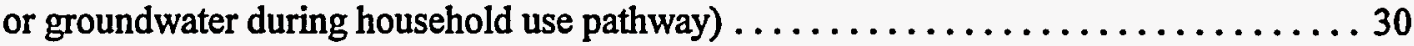

15. On-site future recreational exposure scenario (ingestion of soil) $\ldots \ldots \ldots \ldots \ldots \ldots \ldots, \ldots \ldots \ldots$

16. On-site future recreational exposure scenario (dermal contact with soil) $\ldots \ldots \ldots \ldots \ldots 32$

17. On-site future recreational exposure scenario (inhalation of wind generated dust) $\ldots \ldots 33$

18. On-site future recreational exposure scenario (external exposure to soil) $\ldots \ldots \ldots \ldots 34$

19. On-site future recreational exposure scenario (ingestion of surface water

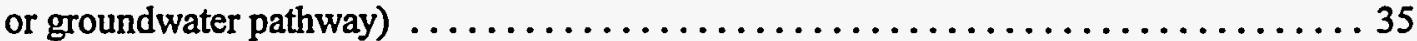

20. On-site future recreational exposure scenario (dermal contact with surface

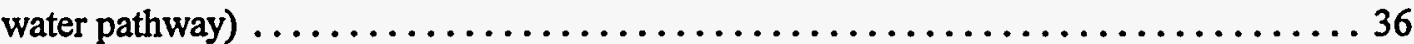

22. Summary of carcinogenic risk for WAG 2 sediment data based on residential

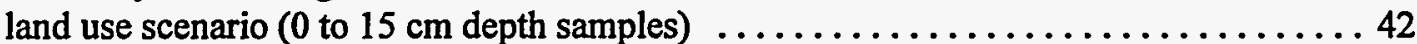

23. Summary of carcinogenic risk for WAG 2 sediment data based on recreational

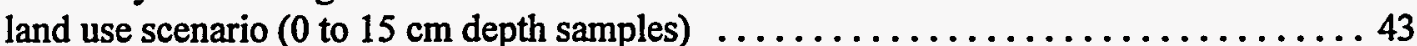

24. Summary of carcinogenic risk for WAG 2 sediment data based on industrial land use scenario $(0$ to $15 \mathrm{~cm}$ depth samples) $\ldots \ldots \ldots \ldots \ldots \ldots \ldots \ldots \ldots . \ldots \ldots 44$

25. Summary table of total carcinogenic risk for WAG 2 sediment data $\ldots \ldots \ldots \ldots \ldots 46$

26. Summary of hazard quotients for noncarcinogenic effects for WAG 2 sediment data based on residential land use scenario ( 0 to $15 \mathrm{~cm}$ depth samples) $\ldots \ldots \ldots \ldots \ldots \ldots . \ldots 50$

27. Summary of hazard quotients for noncarcinogenic effects for WAG 2 sediment data based on recreational land use scenario ( 0 to $15 \mathrm{~cm}$ depth samples) $\ldots \ldots \ldots \ldots . \ldots 51$

28. Summary of hazard quotients for noncarcinogenic effects for WAG 2 sediment data based on industrial land use scenario ( 0 to $15 \mathrm{~cm}$ depth samples) $\ldots \ldots \ldots \ldots \ldots \ldots . \ldots 2$

29. Summary table of hazard indices for noncarcinogenic effects

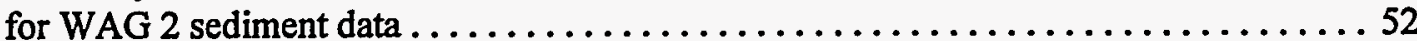

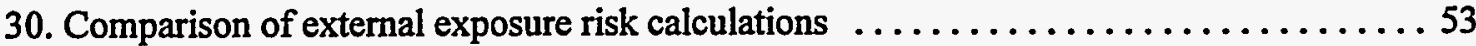




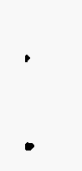




\begin{tabular}{ll} 
& \multicolumn{1}{c}{ ABBREVIATIONS } \\
CERCLA & Comprehensive Environmental Response, Compensation, and Liability Act \\
COCs & contaminants of concern \\
COPCs & chemicals of potential concern \\
DOE & United States Department of Energy \\
EPA & United States Environmental Protection Agency \\
ESP & East Seep monitoring station (at WAG 7) \\
FFA & Federal Facility Agreement \\
FS & Feasibility Study \\
HEAST & Health Effects Assessment Summary Tables \\
HRT & Homogeneous Reactor Test (tributary site draining WAG 9) \\
IRIS & Integrated Risk Information System \\
LMES & Lockheed Martin Energy Systems, Inc. \\
MS1 & Monitoring Station 1 \\
ORNL & Oak Ridge National Laboratory \\
ORO & Oak Ridge Operations \\
PRG & preliminary remediation goal \\
RAGS & Risk Assessment Guidance for Superfund \\
RI & Remedial Investigation \\
RME & reasonable maximum exposure \\
S75 & Trench 7 (in WAG 7) \\
SARA & Superfund Amendments and Reauthorization Act \\
SAS & Statistical Analysis System \\
TDEC & Tennessee Department of Environment and Conservation \\
TVA & Tennessee Valley Authority \\
WAG & Waste Area Grouping \\
\end{tabular}




\section{EXECUTIVE SUMMARY}

This report is one of five reports issued in 1996 that provide follow-up information to the Phase I Remedial Investigation (RI) Report for Waste Area Grouping (WAG) 2 at Oak Ridge National Laboratory (ORNL). The five reports address areas of concern that could cause potential human health risk and ecological risk within WAG 2 at ORNL. The purpose of this report is to present a summary of the human health risk assessment results based on the data collected for the WAG 2 Phase I RI. Estimates of risk are provided based on measured concentrations in the surface water, floodplain soil, and sediment of White Oak Creek, Melton Branch, and their tributaries.

The human health risk assessment methodology used in this risk assessment is based on Risk Assessment Guidance for Superfund (RAGS). First, the data for the different media are evaluated to determine usability for risk assessment. Second, through the process of selecting chemicals of potential concern (COPCs), contaminants to be considered in the risk assessment are identified for each medium, and the representative concentrations for these contaminants are determined. Third, an assessment of exposure potential is performed, and exposure pathways are identified. Subsequently, exposure is estimated quantitatively, and the toxicity of each of the COPCs is determined. The results of these analyses are combined and summarized in a risk characterization.

The floodplain soil and sediment cores are apportioned into six areas. The Intermediate Holding Pond and Middle White Oak Creek areas are located on White Oak Creek upstream of the Melton Branch-White Oak Creek confluence. Lower White Oak Creek is located downstream of the confluence and Upper, Middle, and Lower Melton Branch Creek areas are located on Melton Branch upstream of the Melton Branch-White Oak Creek confluence. Analytical core data collected at these locations are used to assess risk from the recreational, industrial, and residential scenarios. In addition, data from an Ultrasonic Ranging and Data Systems walkover of WAG 2 are used to calculate the risk from external exposure for each area.

For the analysis of the residential land use scenario for floodplain soil and sediment, the carcinogenic risk at all of the reaches is above the target risk range since all risk values are greater than 1.0E-04. The risk values for subsurface and surface data for the residential land use scenario are within an order of magnitude of each other. Floodplain soils and sediment at all reaches present high human health risks to receptors under the residential scenario (risk $\geq 1.0 \mathrm{E}-4$ ), the surface sediments in reach IHP present the greatest human health risk for future residents, with a risk value of $7.8 \mathrm{E}-1$. The primary contaminants for exposure to WAG 2 floodplain soils and sediment are ${ }^{60} \mathrm{Co}$ and ${ }^{137} \mathrm{Cs}$, via the external exposure to radionuclides pathway.

The recreational risk values for all of the reaches vary from 2.8E-3 to 1.1E-5. The risk values for the subsurface sediment of reach MWOC (the lower portion of White Oak Creek above the confluence of White Oak Creek and Melton Branch) and the subsurface and surface sediment of reach MMBC (Melton Branch in the vicinity of WAG 5) are 1.6E-5, 1.1E-5, and 6.4E-5, respectively, which fall in the target risk range of $1 \mathrm{E}-06$ to $1 \mathrm{E}-04$. However, the carcinogenic risk values for all other reaches are greater than $1 \mathrm{E}-04$ and therefore represent high risk to the recreational user. The surface sediments in reach IHP (which includes the intermediate holding pond area) present the greatest human health risk to recreators, with a carcinogenic risk value of $2.8 \mathrm{E}-3$. 
The industrial carcinogenic risk values for the reaches in WAG 2 vary from $1.9 \mathrm{E}-3$ to $3.2 \mathrm{E}-1$ for the industrial land use scenario. Because these values are greater than $1 \mathrm{E}-04$, they represent high risk for the future industrial worker due to exposure to WAG 2 contaminants. As with the other land use scenarios, the surface sediments in reach IHP (the intermediate holding pond area) present the greatest human health risk to industrial workers, with a carcinogenic risk value of $3.2 \mathrm{E}-1$.

Mercury, manganese, and chromium were identified a the primary contaminants of concern (COCs) for the residential land use scenario, and all of the defined reaches exceeded unity for the hazard index. The hazard quotients and total hazard indices for all of the reaches are less than 1.0 for the recreational and industrial scenarios. No COCs were identified for this scenario. Therefore, noncarcinogenic human health effects to the future recreational and industrial user are of no concern.

Surface water sampling locations from the 1992 seep task, the 1993-1994 seep task, the tributary assessment task, and the WAG $5 \mathrm{RI}$ are used to assess risk for the recreational and residential scenarios at each measured surface water location in the watershed.

Due to the large number of sites analyzed (more than 170), the full results for the recreational and residential land use scenarios for surface water are presented with risk range maps in the risk characterization section. The most prevalent risk-driving contaminants in surface water are ${ }^{90} \mathrm{Sr}$ and ${ }^{3} \mathrm{H}$. Almost all of the total residential risk results exceed the target risk range and about $20 \%$ of the results exceed a residential risk of 1.0E-2. A total of 120 of the 169 areas analyzed for ${ }^{90} \mathrm{Sr}$ exceed the target risk range, and about $10 \%$ of the sites exceed a risk of $1.0 \mathrm{E}-2$. Risk results exceeding $1.0 \mathrm{E}-2$ for ${ }^{90} \mathrm{Sr}$ are concentrated along Melton Branch and the tributary draining WAG 4. Results for tritium are similar, with more than half of the areas exceeding the target risk range and about $20 \%$ exceeding a risk of 1E-2. In addition to Melton Branch and the tributary draining WAG 4, some areas in WAG 6 exceed a risk of 1E-2. The recreational results (without the fish ingestion pathway) show significantly less risk than the residential pathway with about $15 \%$ of the results exceeding the target risk range and no results above $1.0 \mathrm{E}-2$.

Noncarcinogenic risk results show more than half of the risk results exceeding unity for the residential scenario and that no concern is warranted for any of the sites sampled for noncarcinogenic contaminants under the recreational scenario (without the fish ingestion pathway). 


\section{INTRODUCTION}

\subsection{PURPOSE}

This report is one of five reports issued in 1996 that provide follow-up information to the Phase I Remedial Investigation (RI) Report for Waste Area Grouping (WAG) 2 at Oak Ridge National Laboratory (ORNL). The five reports address areas of concern that could cause potential human health risk and ecological risk within WAG 2 at ORNL. A sixth report on groundwater was part of project activities conducted in FY 1995. The five reports that complete activities conducted as part of Phase I of the RI for WAG 2 are:

1. Waste Area Grouping 2, Phase I Task Data Report: Seep Data Assessment

2. Waste Area Grouping 2, Phase I Task Data Report: Tributaries Data Assessment

3. Waste Area Grouping 2, Phase I Task Data Report: Ecological Risk Assessment

4. Waste Area Grouping 2, Phase I Task Data Report: Human Health Risk Assessment

5. Waste Area Grouping 2, Phase I Task Data Report: Sediment Transport Modeling

The report entitled Remedial Investigation Plan for Waste Area Grouping 2 at Oak Ridge National Laboratory (ORNL 1990) was issued in December 1990. The WAG 2 RI Plan was structured with a short-term component to be conducted while upgradient WAGs are investigated and remediated and a long-term component that will complete the RI process for WAG 2 following remediation of upgradient WAGs. RI activities for the short-term component were initiated with the approval of the United States Environmental Protection Agency (EPA) (Region IV) and the Tennessee Department of Environment and Conservation (TDEC).

The purpose of this report is to present a summary of the human health risk assessment results based on the data collected for the WAG 2 Phase I RI. Estimates of risk are provided based on measured concentrations in the surface water, floodplain soil, and sediment of White Oak Creek, Melton Branch, and their tributaries. Estimates for groundwater risk from wells in WAG 2 are documented in the annual ERMA reports (DOE 1994b, 1995b).

\subsection{BACKGROUND}

WAG 2 consists of White Oak Creek and its tributaries downstream of the ORNL Main Plant area, Melton Branch and its tributaries, White Oak Lake, the White Oak Creek Embayment, the associated flood plains, and the subsurface environment (Fig. 1). The White Oak Creek system drains the White Oak Creek watershed, an area of approximately $16.8 \mathrm{~km}^{2}$ that includes ORNL and associated WAGs. The White Oak Creek system has been exposed to contaminants released from ORNL and associated operations since 1943 and continues to receive contaminants from adjacent WAGs. 


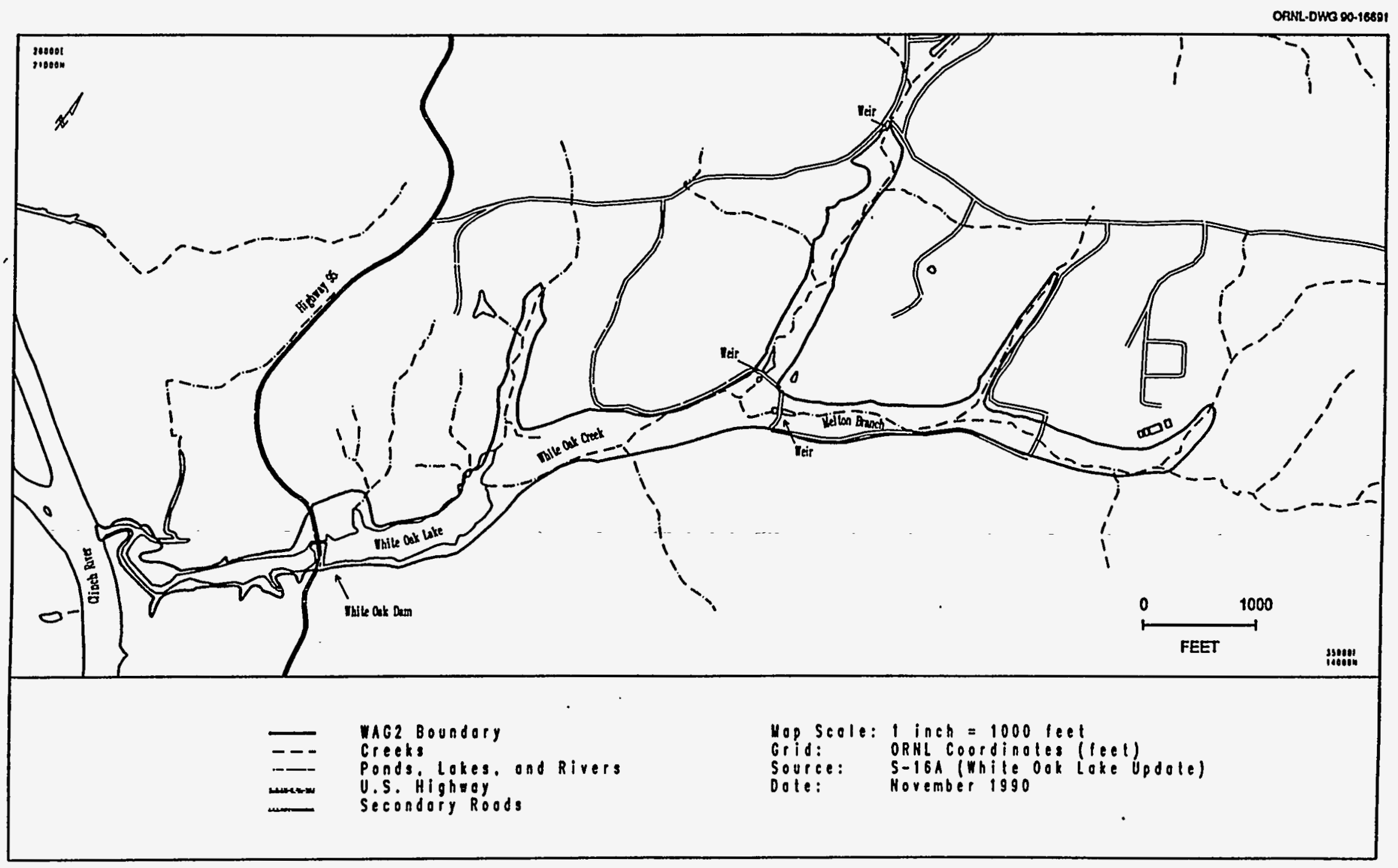

$N$

Fig. 1. White Oak Creek Watershed. 
The WAG 2 RI Plan developed in 1990 was not a prototypical RI plan. It was recognized that full implementation of an RI was inappropriate while contaminants continue to enter the system. A phased effort was adopted in response to the need to take initial steps to protect the public and the environment and characterize and assess risks associated with WAG 2 and the limitations imposed by changing contaminant input. Three phases were initially identified: Phase I was the initial scoping activity to determine the need for early action; Phase $I$ included interim activities during remediation of upgradient WAGs to evaluate potential changes in the contamination status of WAG 2 that would necessitate re-evaluation of the need for early action; and Phase III would be completion of the Comprehensive Environmental Response, Compensation, and Liability Act (CERCLA) process following remediation of the upgradient WAGs. Field activities were initiated in FY 1992 consistent with the RI Plan (ORNL 1990), and a report summarizing Phase I results to date was published in 1993 (DOE 1995a).

On June 20 and 21, 1994, a Data Quality Objectives Workshop was held with representatives of the United States Department of Energy (DOE), EPA, and TDEC. Decisions were made defining the nature and boundaries of the problems for the WAG 2 RI, decision criteria, and inputs to be used for characterizing the site for decision-making purposes. During the workshop, the regulators made recommendations that would alter the initial WAG 2 RI plan. Consequently, the Federal Facility Agreement (FFA) managers from EPA, TDEC, and DOE directed that FY 1995 WAG 2 RI activities would concentrate on meeting FFA requirements.

The FFA managers also directed that the WAG 2 RI be changed to a two-phase field program by eliminating Phase II activities and transferring needed elements into the newly-formed ORNL Environmental Restoration Surface Water Program. A separate FY 1995 WAG 2 RI Work Plan was developed (DOE 1994a) to replace previously identified planning and tasking documents. Emphasis was to be on analysis of existing data, data interpretation, and reporting of results. This document is a report on the results of the human health risk assessment for the environmental data collected in the other tasks. These results will also be used in the White Oak Creek Watershed RI/Feasibility Study (FS).

\subsection{OBJECTIVE}

The objectives of the WAG 2 human health risk assessment are to document the potential health hazards (i.e., risks) that may result from contaminants on or released from the site and provide information necessary for reaching informed remedial decisions. As part of the DOE-Oak Ridge Operations (ORO), ORNL and its associated waste/contamination sites fall under the auspices of the CERCLA, also known as Superfund, as amended by the Superfund Amendments and Reauthorization Act (SARA). The results of the risk assessment will (1) document and evaluate risks to human health, (2) help determine the need for remedial action, (3) determine chemical concentrations protective of current and future human receptors, and (4) help select and compare various remedial alternatives (LMES 1995b).

The human health risk assessment methodology used in this risk assessment is based on Risk Assessment Guidance for Superfund (RAGS) (EPA 1989). First, the data for the different media are evaluated to determine usability for risk assessment. Second, through the process of selecting COPCs, contaminants to be considered in the risk assessment are identified for each medium, and the representative concentrations for these contaminants are determined. Third, an assessment of exposure potential is performed, and exposure pathways are identified. Subsequently, exposure is estimated 
quantitatively, and the toxicity of each of the COPCs is determined. The results of the exposure and toxicity assessments are combined and summarized in the risk characterization section.

\subsection{STUDY GROUP AREAS BY MEDIA}

The floodplain soil and sediment cores are apportioned into six areas as described by Ford et al. (1996) and shown in Fig. 2: the Intermediate Holding Pond and Middle White Oak Creek areas are located on White Oak Creek upstream of the Melton Branch-White Oak Creek confluence. Lower White Oak Creek is located downstream of the confluence and Upper, Middle, and Lower Melton Branch Creek areas are located on Melton Branch upstream of the Melton Branch-White Oak Creek confluence. Analytical core data collected at these locations are used to assess risk from the recreational, industrial, and residential scenarios. In addition, data from an Ultrasonic Ranging and Data Systems walkover of WAG 2 are used to calculate the risk from external exposure for each area.

Surface water sampling locations from the 1992 seep task (DOE 1995a), the 1993-1994 seep task (Hicks 1996), the tributary assessment task (Borders et al. 1996), and the WAG 5 RI (Bechtel 1995) are used to assess risk for the recreational and residential scenarios at each measured surface water location in the watershed.

\subsection{RISK EXPOSURE SCENARIOS}

Industrial, recreational, and residential future land use exposure scenarios are used to evaluate risk for the WAG 2 assessment. These scenarios reflect the primary scenarios that are present at Lockheed Martin Energy Systems, Inc. (LMES) sites (LMES 1996b) and reflect the consensus among the decision-makers about what land use scenarios should be evaluated in a baseline risk assessment. A reasonable maximum exposure (RME) estimate of the risk to hypothetical future human receptors for each scenario is calculated. As an operating assumption, current contaminant concentrations are used for the calculation of future risk. The use of current concentrations generally defines the maximum exposure to WAG 2 contaminants under these land use scenarios since it is expected that the majority of risk-driving radionuclides will decay to lower concentrations over time and releases to the WAG 2 environment will be abated as upgradient sources are remediated.

The future industrial scenario is evaluated using industrial values presented by LMES (1996a). The exposure pathways evaluated for the future industrial exposure scenario to sediment and floodplain soil are incidental ingestion, inhalation of dust/particulates, dermal contact, and external exposure to radiation. It is assumed that future industrial receptors will obtain drinking water from off-site sources, so an industrial scenario is not calculated for surface water.

The pathways evaluated for exposure to the WAG 2 sediment for the industrial scenario were also selected for the future recreational receptor. In addition, surface water from the WAG 2 seeps were investigated for the recreational scenario. Exposure pathways evaluated for future recreational land use for surface water include incidental ingestion, dermal contact, and ingestion of contaminated fish. Due to the inability of some areas of the watershed to support subsistence fishing, the recreational results for each surface water location are presented with and without the fish ingestion pathway.

The future on-WAG residential scenario is also evaluated. This scenario is judged to be a conservative scenario because WAG 2 is within DOE boundaries; it is unlikely in the near or even foreseeable future that DOE will release the land for residential development. Analytes with risks 


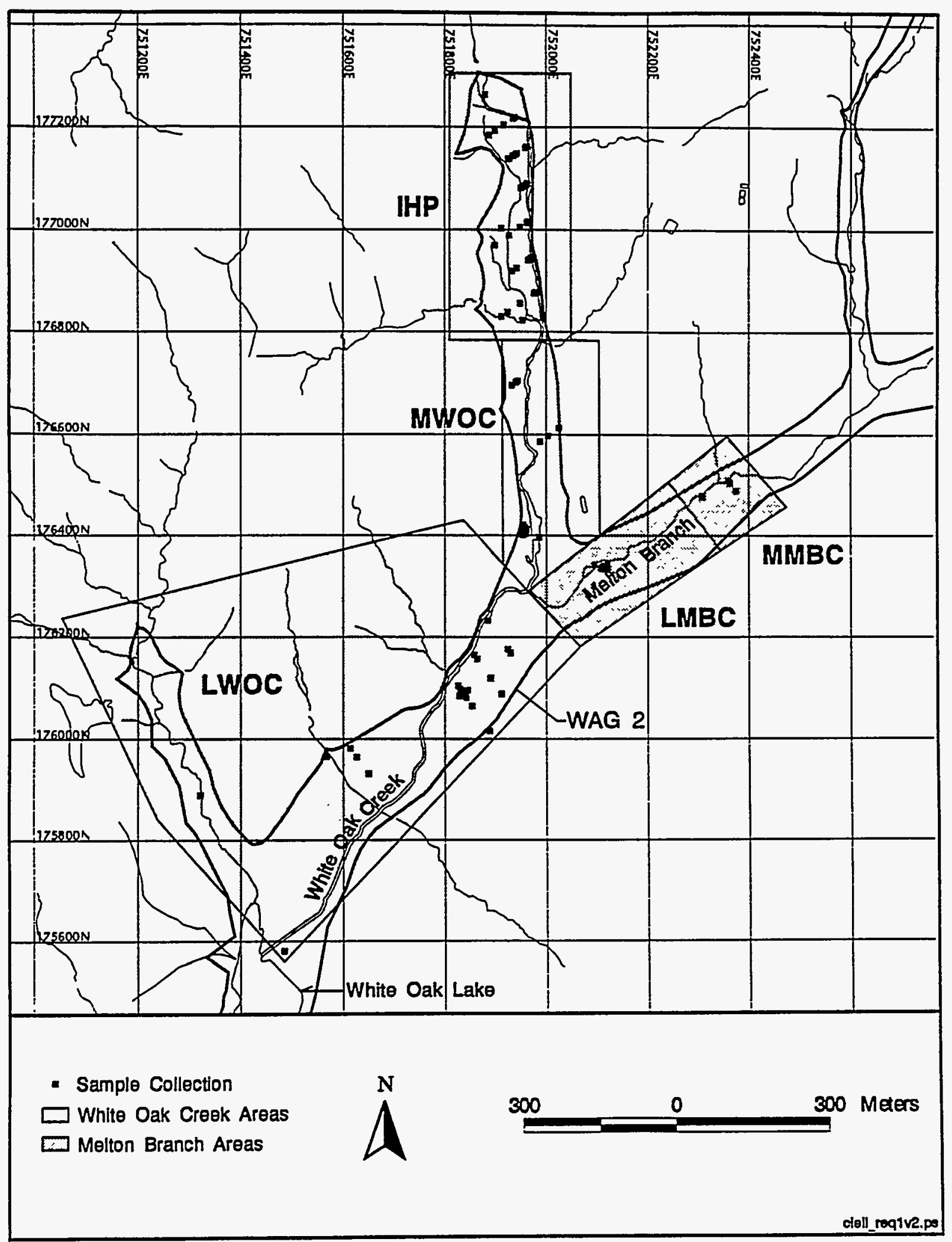

Fig. 2. Reach groupings for assessment of WAG 2 sediment. 
below the EPA target risk range levels for the conservative residential evaluation should not require further action in terms of remediation. Exposure is calculated for a lifetime, which includes exposures as both child and adult. Exposure pathways evaluated for the hypothetical future on-WAG residential scenario for floodplain soil and sediment are ingestion of floodplain soil and sediment, ingestion of home-grown produce, inhalation of contaminants, dermal contact, and external exposure to radiation. The residential exposure pathways evaluated for surface water include ingestion of surface water, dermal contact with surface water during household use, and inhalation of volatiles and radionuclides in surface water during household use.

The following sections describe the methodology used in evaluating the WAG 2 analytical data, physical characteristics, potential pathways, and potential receptors for use in quantifying the potential risk to human health from exposure to WAG 2 chemicals of potential concern (COPCs). Organization of the WAG 2 risk assessment is as follows:

- Chapter 1. Introduction. A general overview of the report is provided.

- Chapter 2. Identification of Chemicals of Potential Concern. A discussion of data evaluation and analysis and the selection of COPCs is presented.

- Chapter 3. Exposure Assessment. Exposure scenarios and exposure pathways are defined. Equations for exposure calculations and values for exposure parameters are provided and discussed.

- Chapter 4. Risk Characterization. Information from the exposure and toxicity assessments is used to calculate carcinogenic and noncarcinogenic risk for WAG 2 exposure pathways.

- Chapter 5. References. References used in the preparation of the WAG 2 Risk assessment are given.

- Appendix A. Carcinogenic Risk Tables for the Sediment in Floodplain Soil Data Used in the WAG 2 Assessment

- Appendix B. Noncarcinogenic Hazard Quotient Tables for the Sediment in Floodplain Soil Data Used in the WAG 2 Assessment

- Appendix C. Carcinogenic Risk Tables for the Tributaries Data Used in the WAG 2 Assessment

- Appendix D. Noncarcinogenic Hazard Quotient Tables for the Tributaries Data Used in the WAG 2 Assessment

- Appendix E. Carcinogenic Risk Tables for the Seep Task Data Used in the WAG 2 Assessment

- Appendix F. Noncarcinogenic Hazard Quotient Tables for the Seep Task Data Used in the WAG 2 Assessment 


\section{IDENTIFICATION OF CHEMICALS OF POTENTIAL CONCERN}

The following discussion addresses the analytical data evaluation steps necessary to (1) identify a set of chemicals that are likely to be site-related and (2) report analyte concentrations of acceptable quality for use in a quantitative risk assessment.

\subsection{GENERAL DATA COLLECTION CONSIDERATIONS}

The data presented in this assessment are from recent sampling periods (DOE 1995a, Hicks 1996, Ford et al. 1996, Borders et al. 1996, Bechtel 1995). Summary statistics and the methods used for collection are described in these constituent reports. Background data sets used for sediment screening were supplied by Bechtel. Concentrations of analytes detected in each of the WAG 2 media were compared with background data to ensure that only site-related contamination is investigated in the risk assessment to the extent possible. Those analytes that did not exceed background concentrations were eliminated from further consideration.

\subsection{GENERAL DATA EVALUATION CONSIDERATIONS}

For evaluating the sediment data, WAG 2 was divided into six reaches that are different due to their physical settings and geographical location. The analytical data were evaluated separately for each reach. The surface water data were categorized and analyzed separately based on their two constituent reports: tributaries (Borders et al 1996) and seeps (Hicks 1996). Total carcinogenic risk values and noncarcinogenic hazard quotients for the WAG 2 surface water COPCs are calculated individually for both tributaries and seeps. Other seep data from the first phase of the WAG 2 RI (DOE 1995a) and the WAG 5 RI (Bechtel 1995) were added to maximize the coverage and confidence provided by the surface water risks results and to address chain-of-custody problems present in the Phase $I^{90} \mathrm{Sr}$ results. The chain-of-custody issues are addressed in Hicks (1996); this report examines the effect of excluding the ${ }^{90} \mathrm{Sr}$ results with chain-of-custody problems by calculating and presenting the ${ }^{90} \mathrm{Sr}$ risks with and without the suspect data.

\subsection{DATA EVALUATION/PREPARATION}

The data included in this risk assessment are the result of inorganic, organic, and radionuclide analyses of samples from various sampling locations within WAG 2 . Fully validated data, grouped by medium, were received in electronic format from the WAG 2 principal investigators (Diana Hicks/ Dennis Borders- Surface Water, Clell Ford- Sediment/Floodplain Soil) and from Bechtel National, Inc. The ASCI text electronic files were read into a Statistical Analysis System (SAS; SAS Institute Inc.) data base, and an independent review and a quality check of the data were conducted. The data evaluation was performed in accordance with RAGS (EPA 1989). This process assisted in selecting the COPCs which are being evaluated quantitatively in this WAG 2 human health risk assessment.

\subsubsection{Data Validation Considerations}

The data validation method for each medium is described in the respective constituent reports (Ford et al. 1996, Hicks 1996, Bechtel 1995, DOE 1995a, Borders et al 1996). The evaluation/validation process performed included comparison of selected samples with associated 
blanks using two criteria: (1) if the concentration of the analyte in the sample was at least five times greater than the maximum concentration detected in the associated blank, then the analyte concentration was not changed from the reported value and (2) if the concentration of the analyte in the sample was greater than the concentration found in the blank, but less than five times the concentration in the blank, then the analyte concentration was changed to reflect the concentration reported in the blank, and a nondetect qualifier (U) was also added to the data set for these analytes. For common laboratory contaminants such as acetone, 2-butanone, methylene chloride, and phthalate esters, if the concentration of the analyte in the sample was at least 10 times greater than the associated maximum concentration detected in the blank, then the analyte concentration was not changed from the reported value.

The standard methods of data evaluation described in RAGS (EPA 1989) were employed. Specifically, data qualifiers were evaluated where (1) J (although indicative of an estimated value) was treated as a detected analyte and was included in the risk assessment data set; (2) $U$ was treated as a nondetected analyte, and the reported detection limit was used as the concentration value; and (3) UJ was treated as data flagged with a $U$ qualifier. When an analyte was not detected (U or UJ) in any of the media samples, a separate data set for the medium (i.e., a nondetected analytes data set) was created.

For those analytes with all nondetected values, no distribution test was performed and those analytes are not part of the quantitative analysis for that site. For the radionuclide analyses, some closely related isotopes were grouped, and a total concentration value was reported for each group. In these cases, the most conservative toxicity value for the isotopes (i.e., the toxicity value that would result in the highest risk) was employed. Isotope groups in question were: (1) ${ }^{233} \mathrm{U}$ and ${ }^{234} \mathrm{U},(2){ }^{89} \mathrm{Sr}$ and ${ }^{90} \mathrm{Sr}$, and $(3)^{239} \mathrm{Pu}$ and ${ }^{240} \mathrm{Pu}$. This association of isotopes was necessary since several samples were analyzed and results were reported in isotope groups only.

\subsubsection{Determination of Chemicals of Potential Concern}

COPCs are the contaminants that are determined to be site-related and whose data are of sufficient quality to carry forward into the quantitative risk assessment (EPA 1989). In this section, the method for determining COPCs is developed. The determination of representative concentrations for each analyte is the first step in this process. A minimum of one detected hit signified a detected analyte. Frequency distributions were fitted to different statistical distributions of detected concentrations by comparison to normal and lognormal distributions. The distribution resulting in a fit with the highest confidence value was chosen. The minimum, maximum, and mean concentrations were determined for each fitted distribution. The upper 95th percentile confidence limit on the mean was calculated according to the appropriate distribution. For lognormal distributions, all calculated values were transformed back into normal space. Finally, the smaller of the maximum detected concentration or the upper 95th percentile confidence limit was chosen as the representative concentration. This calculated concentration is compared to a number of criteria to determine whether the analyte should be carried further in the risk assessment as a COPC. A more detailed discussion of determining the exposure concentration is given in Sect. 3.4.4.

The number of COPCs that can be quantitatively evaluated is limited by the availability of chemical-specific, EPA-approved toxicity information (i.e., slope factors, reference doses, and reference concentrations) (EPA 1993, 1994). The most current EPA-approved toxicity information was obtained from the electronic data bases of the Integrated Risk Information System (IRIS) and the Health Effects Assessment Summary Tables (HEAST) as summarized in BEIAS (1995). The analytes that could not be evaluated quantitatively in the WAG 2 risk assessment due to a lack of toxicity 
information are not considered further in this risk assessment. The remaining COPCs with EPA-approved toxicity information are evaluated quantitatively in this assessment.

\subsubsection{Floodplain soil and sediments}

The summary statistics for the floodplain soil and sediment data sets were carried out for each reach within WAG 2 and are presented by Ford et al. (1996). The floodplain soil and sediment data are categorized by reach, and radionuclide data are further characterized by surface and subsurface regions. Surface data are collected from 0 to $15 \mathrm{~cm}$ below the ground surface, and subsurface data are collected at greater than $15 \mathrm{~cm}$ below the ground. Since metal and organic results were not segregated according to depth, all of these results are used as surface data.

A large number of tables is usually associated with the development of COPCs in a baseline human health risk assessment. However, due to space considerations, all of these tables are not published in this document. Tables with the following information are available upon request either electronically or as hard copy from the Lockheed Martin Energy Research Corporation (LMER) Risk Analysis Section of the Health Sciences Research Division at ORNL:

1. the analytes detected in each WAG 2 reach;

2. the number of detected concentrations per number of observations (i.e., frequency of detection);

3. the distribution type (i.e., normal, lognormal, or no distribution test);

4. the range for nondetects (i.e., the detection limits);

5. the range of detected values (minimum and maximum);

6. the upper 95th percentile confidence limit on the mean;

7. the representative concentration (smaller of maximum detected concentration and the upper 95th percentile confidence limit on the mean);

8. the background concentration for the analyte, determined by the following formula: two times the mean of the background sediment samples for each analyte detected in the WAG 2 data;

9. the contaminants screened out by background (i.e., when the maximum detected value is less than background value);

10. the residential soil preliminary remediation goal (PRG), which is the minimum PRG value of the following residential exposure pathways considered in the WAG 2 risk assessment: ingestion, inhalation, dermal, external exposure pathways or the total pathway risk; and

11. an indication of whether the representative concentration is below the PRG value and is therefore eliminated from further consideration as a COPC.

The PRG value in the table is compared to the representative concentration to help determine the COPC. The analytes considered as COPCs for the WAG 2 floodplain soil and sediment data are those remaining after the background and residential PRG comparison. Carcinogenic risk values and noncarcinogenic hazard quotients based on exposure to COPCs for the WAG 2 sediment in the 
floodplain soils were calculated and are included in Appendixes A and B of this report. The results of this assessment are discussed in the risk characterization portion of this report (Sect. 4). A list of the COPCs for floodplain soil and sediment are presented in Table 1.

Table 1. COPCs for floodplain soil and sediment

\begin{tabular}{llll}
\hline${ }^{60} \mathrm{Co}$ & Aroclor 1260 & ${ }^{228} \mathrm{Th}$ & Antimony \\
${ }^{137} \mathrm{Cs}$ & Benzo[a]pyrene & ${ }^{230} \mathrm{Th}$ & Barium \\
Chromium VI & Dibenz[a,h]anthracene & ${ }^{89190} \mathrm{Sr}$ & Aroclor 1254 \\
Manganese & ${ }^{241} \mathrm{Am}$ & ${ }^{233234} \mathrm{U}$ & ${ }^{239240} \mathrm{Pu}$ \\
Mercury & ${ }^{244} \mathrm{Cm}$ & ${ }^{235} \mathrm{U}$ & Benzo[a]anthracene \\
Nickel & ${ }^{238} \mathrm{Pu}$ & ${ }^{238} \mathrm{U}$ & \\
\hline
\end{tabular}

\subsubsection{Surface water}

. The surface water data provided for consideration of the WAG 2 risk assessment were used to calculate carcinogenic risk and noncarcinogenic human health effects due to exposure to WAG 2 contaminants. The surface water data analyzed include data from the selected locations for the tributaries assessment task (Borders et al. 1996) and data from the seeps task identified from the compilation of two phases of the WAG 2 RI and the WAG 5 RI surface water data sets. Tables used in developing COPCs are available electronically or as hard copy from the LMER Risk Analysis Section of the Health Sciences Research Division at ORNL. These are the same types of tables discussed in the previous section for floodplain soil and sediment with the exception of items 8 and 9 , the comparison to background tables.

Tributary assessment task. The tributary assessment task collected numerous samples from a limited number of contaminants at eight locations within the watershed. COPCs identified from the more limited tributaries data include barium, boron, ${ }^{137} \mathrm{Cs},{ }^{60} \mathrm{Co}$, manganese, mercury, strontium (metal), ${ }^{90} \mathrm{Sr}$, tritium, and zinc. The total carcinogenic risk for these COPCs in the WAG 2 tributaries was calculated for the exposure scenarios described in Sect. 3, and the results are provided in Appendix $C$. The total hazard index results, which determine noncarcinogenic human health effects based on exposure to contaminants in the WAG 2 tributaries, are provided in Appendix D.

The table in Appendix $C$ provides the total carcinogenic risk to future WAG 2 residents based on exposure to the carcinogenic $\mathrm{COPCs}{ }^{137} \mathrm{Cs},{ }^{60} \mathrm{Co},{ }^{90} \mathrm{Sr}$, and tritium. The risk values shown in the table are the sum of all the individual exposure pathways (ingestion, inhalation, and dermal contact with surface water) for each contaminant at each sample identification number. The table also provides the sample identification number, the date and time the sample was collected, and the discharge flow.

The table in Appendix $\mathrm{D}$ provides the totalnoncarcinogenic hazard index based on residential exposure to the noncarcinogenic COPCs barium, boron, manganese, mercury, strontium, and zinc. The hazard index values shown in the table represent the sum of the hazard quotients for the ingestion, inhalation, and dermal contact with surface water pathways. As is the case with the carcinogenic risk tables in Appendix C, the table also provides the sample identification number, date and time the sample was collected, and the discharge flow. 
Seeps task data. The seeps task data is a compilation of the three grab sample data sets discussed earlier (DOE 1995a, Hicks 1996, Bechtel 1995). These data include a number of main stem and tributary grab samples in addition to the seeps that were sampled. The COPCs identified from this compiled data set are listed in Table 2.

Table 2. COPCs for the seep task data

\begin{tabular}{llll}
\hline 1,1-Dichloroethene & Vinyl Chloride & ${ }^{226} \mathrm{Ra}$ & ${ }^{212} \mathrm{~Pb}$ \\
1,1-Dichloroethane & ${ }^{14} \mathrm{C}$ & ${ }^{228} \mathrm{Ra}$ & ${ }^{228} \mathrm{Th}$ \\
cis-1,2-Dichloroethene & ${ }^{90} \mathrm{Sr}$ & ${ }^{235} \mathrm{U}$ & ${ }^{230} \mathrm{Th}$ \\
Chloroform & ${ }^{99} \mathrm{Tc}$ & ${ }^{238} \mathrm{U}$ & Molybdenum \\
Tetrachloroethene & ${ }^{3} \mathrm{H}$ & Arsenic & ${ }^{241} \mathrm{Am}$ \\
${ }^{239240} \mathrm{Pu}$ & ${ }^{45} \mathrm{Ca}$ & ${ }^{232} \mathrm{Th}$ & Methylene Chloride \\
1,1,2-Trichloroethane & ${ }^{232} \mathrm{U}$ & ${ }^{60} \mathrm{Co}$ & $1,2-$ Dichloroethane \\
${ }^{243244} \mathrm{Cm}$ & ${ }^{40} \mathrm{~K}$ & Alpha-BHC & Beta-BHC \\
1,2-Dichloropropane & ${ }^{233234} \mathrm{U}$ & ${ }^{137} \mathrm{Cs}$ & ${ }^{238} \mathrm{Pu}$ \\
1,4-Dichlorobenzene & Beryllium & Trichloroethene & Carbon Tetrachloride \\
Dibromochloromethane & $1,2-D i c h l o r o e t h e n e$ & Nickel & Selenium \\
Fluoride & Antimony & Carbon Disulfide & Vanadium \\
Bis(2-ethylhexyl)pthalate & Nitrate & Benzene & Mercury \\
Cadmium & Boron & Barium & Manganese \\
\hline
\end{tabular}

A large number of contaminants have been identified as COPCs for this data set since there is currently not a sufficient background data set for all of the surface water samples. The total carcinogenic risk and noncarcinogenic hazard index results for the seep COPCs listed in Table 2 are provided in Appendixes $\mathrm{E}$ and $\mathrm{F}$. The carcinogenic risk and noncarcinogenic hazard index values shown are the sum of all individual exposure pathways for identified receptors potentially exposed to the WAG 2 seeps. Potential receptors to contaminants in the WAG 2 seeps include future residents and recreational users. The exposure pathways and land use scenarios evaluated for this assessment are discussed in further detail in the exposure assessment portion of this report (Sect. 3).

\subsubsection{Comparison with Background Data}

Only site-related contaminants should be considered in a risk assessment (EPA 1989). Therefore, a background comparison is conducted where possible to distinguish site-related contaminants from naturally occurring inorganic analytes or contaminants from general anthropogenic sources not related to the site. This step is performed to ensure that risk management decisions are based on the excess risk posed by site-related contaminants rather than natural risk levels from background constituents. It should be noted, however, that the background levels are compared to, but not subtracted from, the site contaminant levels. The background data set used for the screening of analytes in floodplain soil and sediment in this assessment were provided by Bechtel National, Inc (1995). Background screening of seeps and tributaries was not conducted. Data do exist from upstream samples collected for White 
Oak Creek and Melton Branch, but these data are only representative for a small portion of the sites analyzed for surface water. This is due to the fact that the majority of the seeps and tributaries would be best characterized by background groundwater data (from these regions) that are currently unavailable rather than the mainstem headwater background samples. Therefore, the surface water samples have not been screened for background.

Detected analytes were compared to background data to identify COPCs. According to EPA Region IV Supplemental Guidance (1991a), if the maximum detected concentration (i.e., frequency of detection is 21 ) of the contaminant at the site is greater than twice the background concentration, the detected analyte is assumed to be related to the site activities and is therefore a COPC. Otherwise, the analyte is not considered a COPC and is eliminated from further analysis.

\subsubsection{Summary of Essential Nutrients and Residential Preliminary Remediation Goal Screening}

Essential nutrients (including calcium, copper, iron, magnesium, phosphorus, potassium, and sodium) (Dunne 1990) are considered to have little or no adverse effects on human health. In addition, these nutrients are not expected to have been used in any specific WAG 2 operation. Essential nutrients have been included in the summary statistics for the purpose of reporting all the available information but are not considered to be COPCs.

If an analyte is not an essential nutrient or has not been eliminated from consideration as a COPC based on the background screen, the representative concentration is then compared to the residential soil or water PRG value. If the representative concentration is less than the PRG value, then it is also eliminated from consideration as a COPC.

\section{EXPOSURE ASSESSMENT}

The selection of exposure scenarios involves evaluating land use considerations and potential exposure pathway considerations. Exposure scenarios are defined by the completed or potential exposure pathways that are likely to exist for a known or potential receptor population. The potential receptors are identified based on current and future land use considerations.

A decision on the specific land use and its exposure pathways will ultimately be reached in a consensus agreement between involved stakeholders. This represents a major goal of the CERCLA process, and the purpose of this assessment is to inform all stakeholders of the risks involved for specific land uses and exposure pathways that may be considered as target land uses for cleanup purposes. The Site Management Plan and the Common Ground process are the two primary mechanisms for making these determinations.

The conceptual model for the residential, industrial, and recreational land use scenarios that are evaluated in this report for WAG 2 floodplain soil and sediment is presented in Fig. 3. This model illustrates the results of the exposure pathway evaluation. These scenarios and exposure pathways were selected as potential pathways of concern at WAG 2 based on agreements with stakeholders (LMES 1996b) about the scenarios and pathways to be evaluated for human health risk assessments at DOE-ORR sites and on the nature of the contaminated site (floodplain soil and sediment). Sources of contamination may be considered to be primary or secondary in nature. The main plant area and source areas within the watershed are considered to be the primary sources of contamination. Secondary sources of contamination are the contaminated media that have been identified at the 
Conceptual Model for Receptors on WAG 2

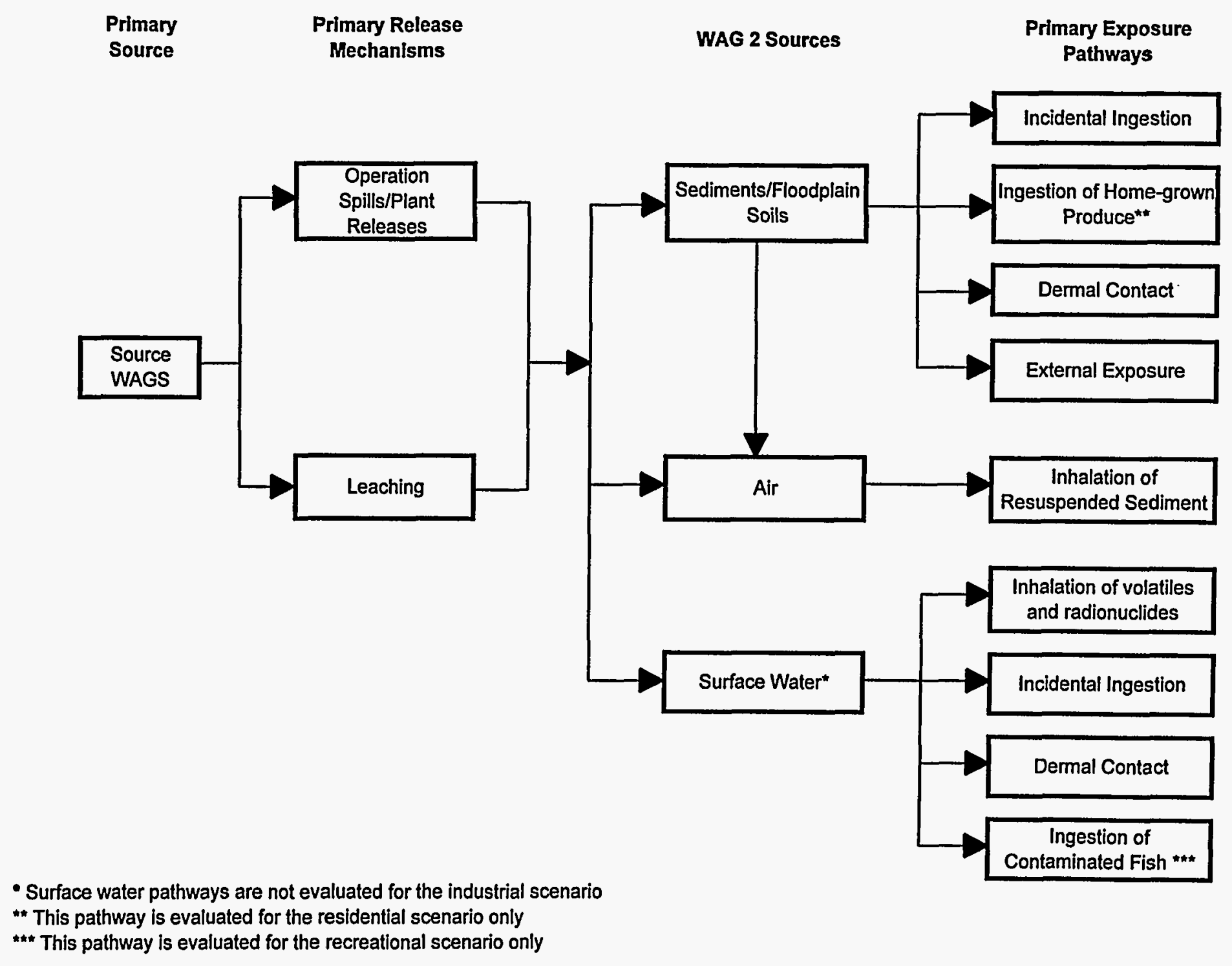

Fig. 3. Exposure assessment conceptual model. 
WAG. For this assessment, the sediment and the floodplain soils are considered as secondary sources in the conceptual model; these sediments can be resuspended and deposited in other areas. Therefore, the air pathway is also considered as a potential secondary source of contamination. The evaluation of release mechanisms identifies potentially contaminated environmental media based on the physical and chemical properties of the contaminants and the characteristics of the medium where they are found. For this assessment, leaching and historical plant releases/operation spills are the primary release mechanisms, resulting in the contamination of the WAG 2 sediment. The primary exposure pathways of concern chosen for the assessment (Fig. 1) are described in Sect. 3.3.

\subsection{CURRENT LAND USE}

Since WAG 2 is located within the confines of ORNL, public access is currently denied. No actively used office or laboratory buildings are located within the vicinity of WAG 2 . For these reasons, current land use is designated as "restricted industrial," and no current on-WAG exposure scenarios are evaluated. The land uses that are evaluated are based on current concentrations and potential future land uses that are described in the next section.

\subsection{FUTURE LAND USE}

If institutional controls were removed from WAG 2, it is possible that receptor populations could be adversely affected by existing site contamination. Because the future land use for WAG 2 has not yet been determined, the risks associated with various land use scenarios have been evaluated. Three future land use scenarios are considered in this report: industrial, residential, and recreational. The purpose of evaluating future land use scenarios as part of the risk assessment is to establish whether remedial action is necessary for alternate land uses by determining if the cumulative risk or hazard index from the source areas could exceed levels of concern. The WAG 2 future land use scenario is based on the assumption that industrial workers, residents, or recreational users of WAG 2 could be exposed. Current contaminant concentrations are used for the on-site assessment of future exposure. Radioactive decay of contaminants is incorporated in the slope factor used to calculate risk but not in the derivation of the exposure concentration. This represents a likely maximum exposure to WAG 2 contaminants and will serve to define the potential human health risks that would exist if residential occupation were to begin within a short time frame. This is considered to be the RME for this assessment.

\subsubsection{Industrial Land Use Scenario}

Under this scenario, industrial workers are expected to be routinely exposed to contaminated media within a commercial area or industrial site. The future industrial scenario is evaluated using industrial default occupational values provided in EPA guidance (EPA 1991b, 1991c). Since there is a potential for the use of heavy equipment and related traffic in and around the contaminated floodplain soils and sediment in an unrestricted industrial scenario, soils and sediment could be disturbed, thereby producing particulate emissions which could then be inhaled by the industrial worker. It should be noted that the assumptions and default parameters for the industrial land use scenario do not reflect the use of protective clothing or other safety precautions. 


\subsubsection{Residential Land Use Scenario}

Under residential land use, future residents are expected to be in frequent, repeated contact with contaminated media. The assumptions in this scenario account for daily exposure over the long term and generally result in the highest potential exposures and risk. In an industrial area where redevelopment for homes is not feasible now or in the foreseeable future, future land use planning scenarios would be more accurately reflected as industrial rather than residential. However, to provide a conservative assessment of risk, a residential land use scenario is assumed as one of the potential receptors for this assessment. Consequently, appropriate default parameters and equations for residential land use were evaluated. An off-WAG residential land use scenario was not investigated for this report. It would provide human health risk results for contamination which could potentially migrate from the WAG 2 area. However, the off-WAG residential scenario is addressed in the sediment transport modeling task report (Clapp 1996).

Under the residential land use scenario, residents are expected to be continuously exposed to contaminated media. Exposure is higher than that under the industrial scenarios because exposure is more frequent and lasts for a longer duration of time. Exposure is calculated for a lifetime, which includes exposures for the receptor as both child and adult.

\subsubsection{Recreational Land Use Scenario}

This scenario addresses exposure to people who spend a limited amount of time at or near WAG 2 while engaging in outdoor activities such as fishing, hunting, and hiking. The recreational land use scenario is also referred to as the "trespasser" or "site visitor" scenario.

\subsection{IDENTIFICATION OF EXPOSURE PATHWAYS}

The exposure pathways evaluated in this assessment are discussed in this section. Each exposure pathway describes a single mechanism by which an individual or a population may be exposed to chemicals originating from the site. Exposure pathways of potential concern are identified by evaluating all components (i.e., source and mechanism of chemical release, transport medium, exposure point, potential human receptors, and routes of exposure) necessary to complete the potential exposure pathway. For an exposure pathway to be considered complete, each component must be identified and must be linked to each of the other components. Routes of exposure (i.e., ingestion, inhalation, dermal absorption, and external exposure to radiation) and potential receptors are important in identifying the validity of an exposure pathway. The descriptions of exposure pathways are presented for each on-WAG future land use exposure.

\subsubsection{Future Industrial Scenario}

\subsubsection{Sediment/floodplain soils}

Sediments and floodplain soils are considered the primary source of exposure to potential industrial receptors. The exposure pathways evaluated for floodplain soils and sediment include (1) incidental ingestion, (2) dermal contact, (3) inhalation of wind-generated dust particulates, and

(4) external exposure to radionuclides in the soil. The results for each of these pathways are given in Appendixes A and B and are discussed in Sect. 4. 


\subsubsection{Surface water}

No surface water pathways are evaluated for the industrial receptor since it is assumed that future industrial workers will continue to receive their drinking water from off-site sources.

\subsubsection{Future Residential Scenario}

\subsubsection{Sediment/floodplain soils}

Sediment/floodplain soils are considered a source of exposure to potential on-WAG residential receptors. The exposure routes/pathways evaluated for soils and sediments include (1) incidental ingestion, (2) dermal contact, (3) inhalation of on-site wind-generated dust particulates, (4) external exposure to radionuclides in the soil, and (5) ingestion of home-grown produce cultivated in contaminated floodplain soil and sediment. The results of the risk evaluation for exposure to the WAG 2 sediment are included in Appendixes A and B and are discussed in more detail in Sect. 4.

\subsubsection{Surface water}

Surface water is another source of exposure to potential on-WAG residential receptors. The exposure routes/pathways evaluated for this scenario include (1) incidental ingestion of surface water, (2) dermal contact with surface water during household use, and (3) inhalation of volatiles and radionuclides in surface water during household use. Carcinogenic and noncarcinogenic risks for the residential land use scenario were calculated separately for the following surface water data sets: tributaries and seeps. The results of the risk evaluation for exposure to WAG 2 surface water are shown in Appendixes $\mathrm{E}$ and $\mathrm{F}$.

\subsubsection{Future On-WAG Recreational Scenario}

\subsubsection{Sediment/floodplain soils}

Floodplain soils and sediments would be a source of exposure to potential on-WAG recreational receptors. The exposure pathways evaluated for sediment include (1) incidental ingestion, (2) dermal contact, (3) inhalation of on-site wind-generated dust particulates, and (4) external exposure to radionuclides in the soil.

\subsubsection{Surface water}

Surface water is another source of exposure to potential WAG 2 recreational receptors. The exposure routes/pathways evaluated for the recreational land use scenario include (1) incidental ingestion of WAG 2 surface water, (2) dermal contact with surface water, and (3) ingestion of contaminated fish. The results for each pathway are shown in Appendix $\mathrm{E}$ and $\mathrm{F}$ and described in Sect. 4. Recreational results are characterized in Sect. 4 with and without the fish ingestion pathway since a number of the sampled sites do not have sufficient flow to support fish populations.

\subsubsection{Future Off-WAG Receptor Scenarios}

Future off-WAG receptor risks are calculated based on the results of sediment transport modeling to off-site areas as a result of a major storm event (Clapp et al. 1996). The primary areas of interest include the lower Watts Bar reservoir and the Clinch River from the outfall of White Oak Creek to its confluence with the Tennessee River. The exposure scenarios and pathways to be examined are the 
same as those that were conducted for the Clinch River RI. The Clinch River RI risk assessment (DOE 1995) calculates the risk from exposure to sediment for two different exposure situations. The first scenario, the near-shore sediment exposures, has a high likelihood (receptors are currently exposed) but consists of relatively low exposure durations. These exposures to near-shore sediments result from recreational exposures occurring in the winter during water level draw-down periods as part of the Tennessee Valley Authority's (TVA's) management strategy. The second scenario, exposure to dredged sediments, represents the high exposure durations, but relatively low likelihood, of the sediments being dredged and then used for farmland. Dredging of sediments is controlled by the Corps of Engineers and TVA and will not be permitted without consideration of health hazards; however, dredging activities are considered to address the possibility that uncontrolled disposal of dredge spoils might occur.

\subsubsection{Shoreline scenario}

The shoreline scenario considers recreational activities such as sunbathing, strolling, searching for artifacts, and wading in the fall and winter when the water level of the reservoir is at its lowest. For the modeled releases of ${ }^{137} \mathrm{Cs}$ to the Clinch River and Watts Bar, the near-shore sediment exposure scenario will calculate the risk from five pathways: external exposure, inadvertent ingestion of sediment, inhalation of resuspended sediment, and dermal contact with floodplain soil and sediment. The exposure durations are intended to be representative of recreational use of the exposed shoreline during the months (up to five) of the year when heavier watershed runoff is expected. The management of the water levels serves multiple purposes including navigation, flood control, recreational activities, consistent hydroelectric production, insect control, and erosion control. Figure 4 represents TVA's annual operating plan for Watts Bar.

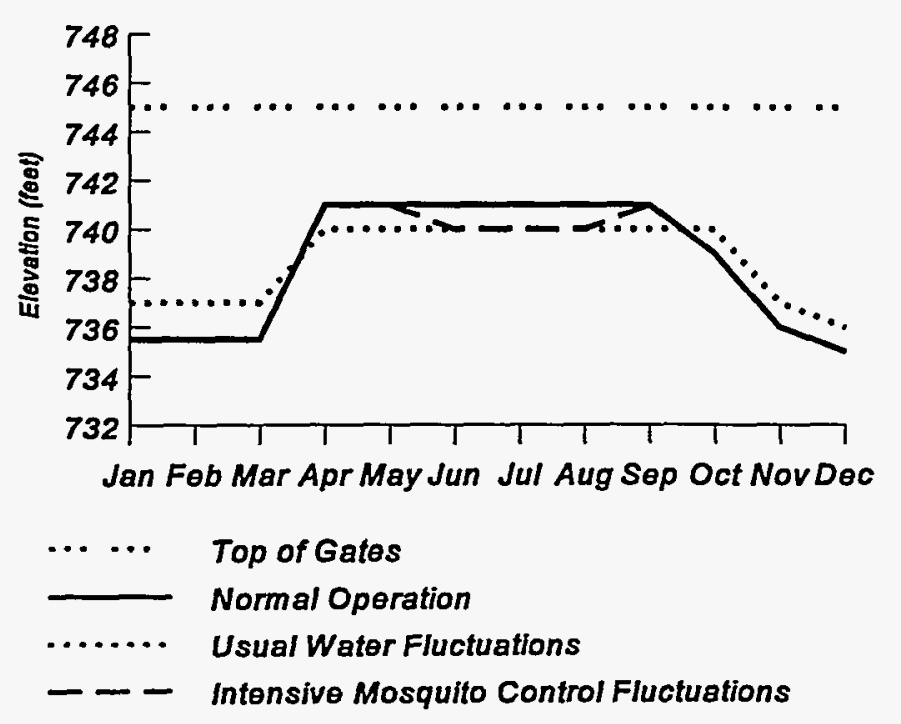

Fig. 4. Watts Bar Annual Operating Guide.

\subsubsection{Dredging scenario}

A dredging scenario is considered to address the possibility that dredging may occur in the future. The scenario assumes that deep water sediment is removed from the reservoir and used as agricultural soils for growing crops and raising livestock. The sediment is assumed to be thick enough that plowing would not significantly dilute the sediment concentrations by mixing with underlying soil. The 
dredged sediment exposure scenario calculates the risk from eight pathways based on the modeled

${ }^{137} \mathrm{Cs}$ concentrations in Clapp et al. (1996): external exposure; inadvertent ingestion of sediment; inhalation of resuspended sediment; dermal contact with sediment; dermal absorption of sediment; and the ingestion of produce, meat, and milk as part of the agricultural scenario. The exposure parameters used for this scenario are those used for the Clinch River RI risk assessment (DOE 1995).

\subsection{QUANTIFICATION OF EXPOSURE}

The quantification of exposure for industrial, residential, and recreational land use are discussed in this section. Exposure is quantified by determining the exposure concentrations and calculating the chemical intakes for the various exposure pathways identified for WAG 2. The chronic daily intake is the amount of a contaminant an individual takes into his or her body per day via ingestion, inhalation, dermal contact, or external exposure to radiation. The first consideration in deriving the chronic daily intake is the methodology employed in developing an exposure concentration, which is the amount of each contaminant in the various media to which receptors are exposed. To calculate the chronic daily intake, the exposure concentration is evaluated in the context of the scenario, exposure pathway, and contaminant-specific exposure variables, such as duration of exposure and intake rate. The representative concentrations of the COPCs are the concentrations used to estimate the RME exposure concentrations for the different pathways. Once the chronic daily intakes for the different potential pathways are determined, risk can be calculated.

Tables 3 to 21 list the equations used to calculate the chronic daily intakes and the exposure variables associated with each exposure pathway considered for the different land use scenarios. The tables provide the chronic daily intake calculations for exposure to contaminants in the WAG 2 sediment in the floodplain soils and surface water contaminants in the WAG 2 tributaries and seeps.

\subsubsection{Calculations for the Industrial Land Use Scenario}

The exposure assumptions associated with all exposure routes included in the industrial land use scenario are listed in Tables 3 to 6. The media concentrations of the COPCs identified in Sect. 2.3 were used in calculating the chronic daily intakes. The smallest of the maximum detected concentration versus the upper 95th confidence limit concentration was assumed to represent the analyte concentration. Conservative chronic daily intake calculations were based on the assumption that an adult spends 8 hours/day, 5 days/week, and 50 weeks/year for 25 years at the facility. Parameters are industrial default occupational values provided as EPA guidance (EPA 1991b, 1991c). It is important to note that the assumptions and default parameters for the industrial land use scenario are reasonable maximum values and do not reflect the use of protective clothing or other safety precautions. The assessment evaluates risk to the general plant employee only and does not evaluate risk to remediation workers.

\subsubsection{Chronic Daily Intake Calculations for the Residential Land Use Scenario}

The exposure assumptions and parameters associated with all exposure routes included in the future residential land use scenario are provided in Tables 7 to 14. For the hypothetical future residential land use scenario, the residential defaults as provided by EPA guidance are used to calculate the chronic daily intakes for a person exposed for 6 years as a child and 24 years as an adult (EPA 1991b, 1991c). The exposure frequency to all media contaminants was assumed to be 350 days/year for an exposure duration of 30 years. 
Table 3. On-site industrial exposure scenario (incidental ingestion of soil or sediment pathway)

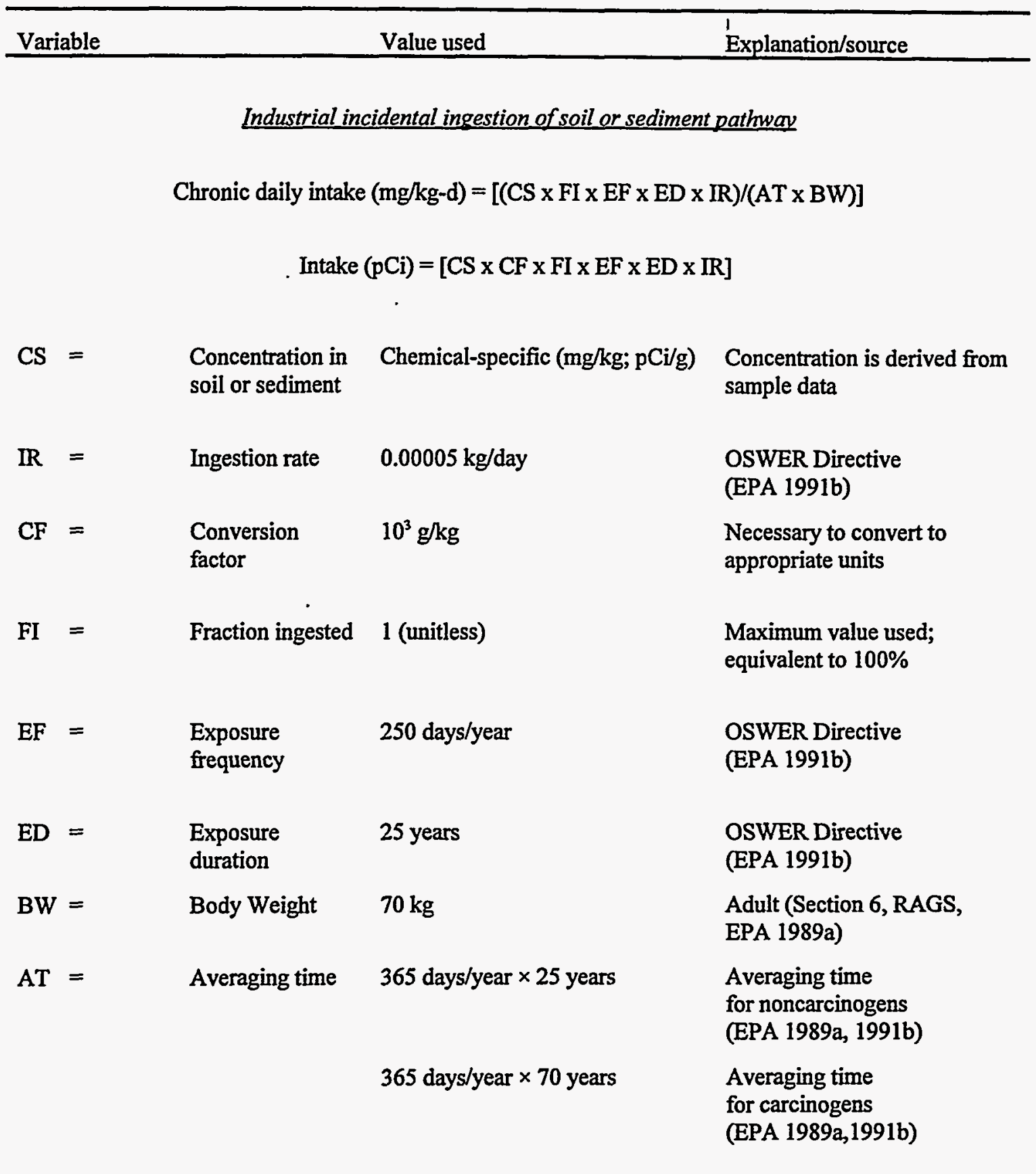


Table 4. On-site industrial exposure scenario (dermal contact with soil or sediment pathway)

\begin{tabular}{|c|c|c|c|}
\hline \multicolumn{2}{|c|}{ Variable } & Value used & \multirow[t]{2}{*}{ Explanation/source } \\
\hline \multicolumn{3}{|c|}{ Industrial dermal contact with soil or sediment pathway } & \\
\hline \multicolumn{4}{|c|}{ Chronic daily intake $(\mathrm{mg} / \mathrm{kg}-\mathrm{d})=[(\mathrm{CS} \times \mathrm{CF} \times \mathrm{AF} \times \mathrm{ABS} \times \mathrm{EF} \times \mathrm{ED} \times \mathrm{SA}) /(\mathrm{AT} \times \mathrm{BW})]$} \\
\hline $\mathrm{CS}=$ & $\begin{array}{l}\text { Concentration in } \\
\text { soil or sediment }\end{array}$ & Chemical-specific (mg/kg) & $\begin{array}{l}\text { Concentration is derived from } \\
\text { sample data }\end{array}$ \\
\hline $\mathrm{CF}=$ & $\begin{array}{l}\text { Conversion } \\
\text { factors }\end{array}$ & $\left(10^{-6} \mathrm{~kg} / \mathrm{mg}\right) \times\left(10^{4} \mathrm{~cm}^{2} / \mathrm{m}^{2}\right)$ & $\begin{array}{l}\text { Necessary to convert } \\
\text { to appropriate units }\end{array}$ \\
\hline $\mathrm{SA}=$ & $\begin{array}{l}\text { Available surface } \\
\text { area }\end{array}$ & $0.316 \mathrm{~m}^{2} /$ day & $\begin{array}{l}\text { 50th Percentile surface area } \\
\text { for head, hands, forearms, for } \\
\text { a male adult (Dermal } \\
\text { Exposure Assessment, } \\
\text { EPA 1992a) }\end{array}$ \\
\hline $\mathrm{AF}=$ & Adherence factor & $1.0 \mathrm{mg} / \mathrm{cm}^{2}$ & $\begin{array}{l}\text { Adherence factor for soil } \\
\text { (EPA Region IV New Interim } \\
\text { Guidance, 2/11/92) }\end{array}$ \\
\hline $\mathrm{ABS}=$ & Absorption factor & $\begin{array}{l}0.001 \text { (unitless) } \\
0.01 \text { (unitless) }\end{array}$ & $\begin{array}{l}\text { Equivalent to } 0.1 \% \\
\text { for inorganics and } 1.0 \% \text { for } \\
\text { organics (EPA Region IV New } \\
\text { Interim Guidance, } 2 / 11 / 92 \text { ) }\end{array}$ \\
\hline $\mathrm{EF}=$ & $\begin{array}{l}\text { Exposure } \\
\text { frequency }\end{array}$ & 250 days/year & $\begin{array}{l}\text { OSWER Directive } \\
\text { (EPA 1991b) }\end{array}$ \\
\hline $\mathrm{ED}=$ & $\begin{array}{l}\text { Exposure } \\
\text { duration }\end{array}$ & 25 years & $\begin{array}{l}\text { OSWER Directive } \\
\text { (EPA 1991b) }\end{array}$ \\
\hline $\mathrm{BW}=$ & Body Weight & $70 \mathrm{~kg}$ & $\begin{array}{l}\text { Adult (Section 6, RAGS, } \\
\text { EPA 1989a) }\end{array}$ \\
\hline \multirow[t]{2}{*}{$\mathrm{AT}=$} & Averaging time & 365 days/year $\times 25$ years & $\begin{array}{l}\text { Averaging time } \\
\text { for noncarcinogens } \\
\text { (EPA 1989a, 1991b) }\end{array}$ \\
\hline & & 365 days/year $\times 70$ years & $\begin{array}{l}\text { Averaging time } \\
\text { for carcinogens } \\
\text { (EPA 1989a, 1991b) }\end{array}$ \\
\hline
\end{tabular}


Table 5. On-site industrial exposure scenario (inhalation of soil or sediment pathway)

\begin{tabular}{|c|c|c|c|c|}
\hline \multicolumn{2}{|c|}{ Variable } & \multicolumn{2}{|r|}{ Value used } & \multirow[t]{2}{*}{ Explanation/source } \\
\hline \multicolumn{4}{|c|}{ Industrial inhalation of soil or sediment pathway } & \\
\hline \multicolumn{5}{|c|}{ Chronic daily intake $(\mathrm{mg} / \mathrm{kg}-\mathrm{d})=\left[\left(\mathrm{CS} \times \mathrm{EF} \times \mathrm{ED} \times \mathrm{R} \times\left(\mathrm{VF}^{-1}+\mathrm{PEF}^{-1}\right)\right) /(\mathrm{AT} \times \mathrm{BW})\right]$} \\
\hline \multicolumn{5}{|c|}{ Intake $(\mathrm{pCi})=\left[\mathrm{CS} \times \mathrm{ED} \times \mathrm{CF} \times \mathrm{EF} \times \mathrm{IR} \times\left(\mathrm{VF}^{-1}+\mathrm{PEF}^{-1}\right)\right]$} \\
\hline $\operatorname{CS}$ & $=$ & $\begin{array}{l}\text { Concentration in } \\
\text { soil or sediment }\end{array}$ & Chemical-specific (mg/kg; pCi/g) & $\begin{array}{l}\text { Concentration is derived from } \\
\text { sample data }\end{array}$ \\
\hline IR & $=$ & Inhalation rate & $20 \mathrm{~m}^{3} /$ day & $\begin{array}{l}\text { OSWER Directive } \\
\text { (EPA 1991b) }\end{array}$ \\
\hline VF & $=$ & $\begin{array}{l}\text { Volatilization } \\
\text { Factor }\end{array}$ & Chemical-specific $\left(\mathrm{m}^{3} / \mathrm{kg}\right)$ & $\begin{array}{l}\text { EPA letter from E.W. Akin to } \\
\text { C.W. McGinn, } 2 / 2 / 93\end{array}$ \\
\hline PEF & $=$ & $\begin{array}{l}\text { Particulate } \\
\text { emission } \\
\text { factor }\end{array}$ & $4.63 \times 10^{9}\left(\mathrm{~m}^{3} / \mathrm{kg}\right)$ & $\begin{array}{l}\text { EPA letter from E.W. Akin to } \\
\text { C.W. McGinn, } 2 / 2 / 93\end{array}$ \\
\hline $\mathrm{CF}$ & $=$ & $\begin{array}{l}\text { Conversion } \\
\text { factor }\end{array}$ & $10^{3} \mathrm{~g} / \mathrm{kg}$ & $\begin{array}{l}\text { Necessary to convert to } \\
\text { appropriate units }\end{array}$ \\
\hline EF & $=$ & $\begin{array}{l}\text { Exposure } \\
\text { frequency }\end{array}$ & 250 days/year & $\begin{array}{l}\text { OSWER Directive } \\
\text { (EPA 1991b) }\end{array}$ \\
\hline ED & $=$ & $\begin{array}{l}\text { Exposure } \\
\text { duration }\end{array}$ & 25 years & $\begin{array}{l}\text { OSWER Directive } \\
\text { (EPA 1991b) }\end{array}$ \\
\hline BW & $=$ & Body Weight & $70 \mathrm{~kg}$ & $\begin{array}{l}\text { Adult (Section 6, RAGS, } \\
\text { EPA 1989a) }\end{array}$ \\
\hline \multirow[t]{2}{*}{$\mathrm{AT}=$} & $=$ & Averaging time & 365 days/year $\times 25$ years & $\begin{array}{l}\text { Averaging time } \\
\text { for noncarcinogens } \\
\text { (EPA 1989a, 1991b) }\end{array}$ \\
\hline & & & 365 days/year $\times 70$ years & $\begin{array}{l}\text { Averaging time } \\
\text { for carcinogens } \\
\text { (EPA 1989a, 1991b) }\end{array}$ \\
\hline
\end{tabular}


Table 6. On-site industrial exposure scenario (external exposure pathway)

\begin{tabular}{|c|c|c|c|}
\hline \multicolumn{2}{|l|}{ Variable } & Value used & Explanation/source \\
\hline \multicolumn{4}{|c|}{ Industrial external exposure pathway } \\
\hline \multicolumn{4}{|c|}{ Dose $(\mathrm{pCi}$-year $/ \mathrm{g})=[\mathrm{CS} \times(1-\mathrm{Se}) \times \mathrm{Te} \times \mathrm{ED} \times \mathrm{EF} \times \mathrm{CF}]$} \\
\hline \multicolumn{2}{|c|}{$\begin{array}{l}\text { CS }=\text { Concentration in } \\
\text { soil or sediment }\end{array}$} & Chemical-specific (pCi/g) & $\begin{array}{l}\text { Concentration is derived from } \\
\text { sample data }\end{array}$ \\
\hline \multicolumn{2}{|c|}{$\mathrm{ED}=$ Exposure duration } & 25 years & $\begin{array}{l}\text { OSWER Directive } \\
\text { (EPA 1991b) }\end{array}$ \\
\hline \multicolumn{2}{|c|}{$\mathrm{EF}=$ Exposure frequency } & 250 days/year & $\begin{array}{l}\text { OSWER Directive } \\
\text { (EPA 1991b) }\end{array}$ \\
\hline \multicolumn{2}{|c|}{$\mathrm{CF}=$ Conversion factor } & 1 year $/ 365$ days & $\begin{array}{l}\text { Necessary to convert to } \\
\text { appropriate units }\end{array}$ \\
\hline $\mathrm{Se}=$ & $\begin{array}{l}\text { Gamma shielding } \\
\text { factor (unitless) }\end{array}$ & 0.2 & $\begin{array}{l}\text { RAGS Part B, EPA 1991a; } \\
\text { Sect. 4.1.2 (default value) }\end{array}$ \\
\hline $\mathrm{Te}=$ & $\begin{array}{l}\text { Gamma exposure } \\
\text { time factor } \\
\text { (unitless) }\end{array}$ & 0.33 & $\begin{array}{l}\text { EPA memo from E.W. Akin to } \\
\text { C.W. McGinn, } 2 / 2 / 93 \\
\text { (based on } 8 \text { hours } / 24 \text { hours) }\end{array}$ \\
\hline
\end{tabular}


Table 7. On-site residential exposure scenario (ingestion of soil or sediment pathway)

\begin{tabular}{|c|c|c|c|c|}
\hline \multicolumn{2}{|c|}{ Variable } & \multicolumn{2}{|r|}{ Value used } & \multirow[t]{2}{*}{ Explanation/source } \\
\hline \multicolumn{4}{|c|}{ Residential ingestion of soil or sediment pathway } & \\
\hline \multicolumn{5}{|c|}{ Chronic daily intake $(\mathrm{mg} / \mathrm{kg}-\mathrm{d})=[(\mathrm{CS} \times \mathrm{FI} \times \mathrm{EF}) / \mathrm{AT}] \times\left[\left(\mathrm{ED}_{\mathrm{c}} \times \mathrm{IR}_{\mathrm{q}} / \mathrm{BW}_{\mathrm{c}}\right)+\left(\mathrm{ED}_{\mathrm{a}} \times \mathrm{IR}_{\mathrm{q}} / \mathrm{BW}\right)\right]$} \\
\hline \multicolumn{5}{|c|}{ Intake $(\mathrm{pCi})=\left[\mathrm{CS} \times \mathrm{CF} \times \mathrm{EF} \times \mathrm{FI} \times\left[\left(\mathrm{ED}_{\mathrm{c}} \times \mathrm{IR}_{\mathrm{\tau}}\right)+\left(\mathrm{ED}_{\mathrm{a}} \times \mathrm{IR}_{\mathrm{J}}\right)\right]\right.$} \\
\hline $\mathrm{CS}$ & $=$ & $\begin{array}{l}\text { Concentration in } \\
\text { soil or sediment }\end{array}$ & Chemical-specific (mg/kg; pCi/g) & $\begin{array}{l}\text { Concentration is derived from } \\
\text { sample data }\end{array}$ \\
\hline $\mathbb{I R}_{\mathrm{c}}$ & $=$ & Ingestion rate & $0.0002 \mathrm{~kg} /$ day & Child rate (EPA 1989a) \\
\hline $\mathbb{R}_{\mathbf{2}}$ & & & $0.0001 \mathrm{~kg} /$ day & Adult rate (EPA 1989a) \\
\hline $\mathrm{CF}$ & $=$ & $\begin{array}{l}\text { Conversion } \\
\text { factor }\end{array}$ & $10^{3} \mathrm{~g} / \mathrm{kg}$ & $\begin{array}{l}\text { Necessary to convert to } \\
\text { appropriate units }\end{array}$ \\
\hline FI & $=$ & Fraction ingested & 1 (unitless) & Maximum value \\
\hline $\mathrm{EF}$ & $=$ & $\begin{array}{l}\text { Exposure } \\
\text { frequency }\end{array}$ & 350 days/year & $\begin{array}{l}\text { OSWER Directive } \\
\text { (EPA 1991b) }\end{array}$ \\
\hline \multicolumn{2}{|c|}{$\mathrm{ED}_{\mathrm{c}}=$} & $\begin{array}{l}\text { Exposure } \\
\text { duration }\end{array}$ & 6 years & $\begin{array}{l}\text { Child and adults exposure for } \\
\text { 30-years (EPA 1991b) }\end{array}$ \\
\hline \multicolumn{3}{|l|}{$\mathrm{ED}_{\mathbf{z}}$} & \multicolumn{2}{|l|}{24 years } \\
\hline \multicolumn{2}{|c|}{$\mathrm{BW}_{\mathrm{c}}=$} & Body Weight & $15 \mathrm{~kg}$ & $\begin{array}{l}\text { Child (OSWER Directive, } \\
\text { EPA 1991b) }\end{array}$ \\
\hline \multicolumn{2}{|l|}{$\mathrm{BW}_{2}$} & & $70 \mathrm{~kg}$ & $\begin{array}{l}\text { Adult (Section 6, RAGS, } \\
\text { EPA 1989a) }\end{array}$ \\
\hline \multirow[t]{2}{*}{$\mathrm{AT}$} & $=$ & Averaging time & 365 days/year $\times 30$ years & $\begin{array}{l}\text { Averaging time } \\
\text { for noncarcinogens } \\
\text { (EPA 1989a, 1991b) }\end{array}$ \\
\hline & & & 365 days/year $\times 70$ years & $\begin{array}{l}\text { Averaging time } \\
\text { for carcinogens } \\
\text { (EPA 1989a, 1991b) }\end{array}$ \\
\hline
\end{tabular}


Table 8. On-site residential exposure scenario (dermal contact with soil or sediment)

\begin{tabular}{|c|c|c|c|}
\hline Variable & & Value used & Explanation/source \\
\hline \multicolumn{4}{|c|}{ Residential dermal contact with soil or sediment scenario } \\
\hline \multicolumn{4}{|c|}{$\begin{array}{l}\text { Chronic daily intake } \\
(\mathrm{mg} / \mathrm{kg}-\mathrm{d})=[(\mathrm{CS} \times \mathrm{CF} \times \mathrm{AF} \times \mathrm{ABS} \times \mathrm{EF}) / \mathrm{AT}] \times\left[\left(\mathrm{SA}_{\mathrm{c}} \times \mathrm{ED}_{\mathrm{c}} / \mathrm{BW}_{\mathrm{c}}\right)+\left(\mathrm{SA}_{\mathrm{a}} \times \mathrm{ED}_{\mathrm{a}} / \mathrm{BW}_{\mathrm{a}}\right)\right]\end{array}$} \\
\hline $\mathrm{CS}=$ & $\begin{array}{l}\text { Concentration in } \\
\text { soil or sediment }\end{array}$ & Chemical-specific (mg/kg) & $\begin{array}{l}\text { Concentration is obtained from } \\
\text { sample data }\end{array}$ \\
\hline $\mathrm{CF}=$ & Conversion factors & $\left(10^{-6} \mathrm{~kg} / \mathrm{mg}\right) \times\left(10^{4} \mathrm{~cm}^{2} / \mathrm{m}^{2}\right)$ & $\begin{array}{l}\text { Necessary to convert to } \\
\text { appropriate units }\end{array}$ \\
\hline $\mathrm{SA}_{c}=$ & $\begin{array}{l}\text { Available surface } \\
\text { area }\end{array}$ & $0.182 \mathrm{~m}^{2} /$ day & $\begin{array}{l}\text { Average surface area for head, } \\
\text { hands, forearms, and lower legs; } \\
\text { for a child }\end{array}$ \\
\hline $\mathbf{S A}_{\mathbf{1}}$ & & $0.53 \mathrm{~m}^{2} /$ day & $\begin{array}{l}\text { and for an adult, respectively } \\
\text { (Dermal Exposure Assessment, } \\
\text { EPA 1992a) }\end{array}$ \\
\hline $\mathrm{AF}=$ & Adherence factor & $1.0 \mathrm{mg} / \mathrm{cm}^{2}$ & $\begin{array}{l}\text { Adherence factor for soil (EPA } \\
\text { Region IV New Interim } \\
\text { Guidance, 2/11/92) }\end{array}$ \\
\hline $\mathrm{ABS}=$ & Absorption factor & $\begin{array}{l}0.001 \text { (unitless) } \\
0.01 \text { (unitless) }\end{array}$ & $\begin{array}{l}\text { Equivalent to } 0.1 \% \text { for inorganics } \\
\text { and } 1.0 \% \text { for organics (EPA } \\
\text { Region IV New Interim } \\
\text { Guidance, } 2 / 11 / 92 \text { ) }\end{array}$ \\
\hline $\mathrm{EF}=$ & $\begin{array}{l}\text { Exposure } \\
\text { frequency }\end{array}$ & 350 days/year & $\begin{array}{l}\text { OSWER Directive } \\
\text { (EPA 1991b) }\end{array}$ \\
\hline $\mathrm{ED}_{\mathrm{c}}=$ & Exposure duration & 6 years & $\begin{array}{l}\text { Two-part (child and adult) } \\
\text { residential exposure } \\
\text { for a } 30 \text {-year duration }\end{array}$ \\
\hline $\mathrm{ED}_{\mathbf{a}}$ & & 24 years & $\begin{array}{l}\text { OSWER Directive } \\
\text { (EPA 1991b) }\end{array}$ \\
\hline $\mathrm{BW}_{\mathrm{c}}=$ & Body weight & $15 \mathrm{~kg}$ & $\begin{array}{l}\text { Child (OSWER Directive, EPA } \\
\text { 1991b) }\end{array}$ \\
\hline $\mathrm{BW}$ & & $70 \mathrm{~kg}$ & $\begin{array}{l}\text { Adult (Section 6, RAGS, } \\
\text { EPA 1989a) }\end{array}$ \\
\hline \multirow[t]{2}{*}{$\mathrm{AT}=$} & Averaging time & 365 days/year $\times 30$ years & $\begin{array}{l}\text { Averaging time } \\
\text { for noncarcinogens } \\
\text { (EPA 1989a; EPA 1991b) }\end{array}$ \\
\hline & & 365 days/year $\times 70$ years & $\begin{array}{l}\text { Averaging time } \\
\text { for carcinogens } \\
\text { (EPA 1989a; EPA 1991b) }\end{array}$ \\
\hline
\end{tabular}


Table 9. On-site residential exposure scenario (inhalation of soil or sediment)

\begin{tabular}{|c|c|c|c|}
\hline Variable & & Value used & Explanation/source \\
\hline \multicolumn{4}{|c|}{ Residential inhalation of soil or sediment scenario } \\
\hline \multicolumn{4}{|c|}{ Chronic daily intake $(\mathrm{mg} / \mathrm{kg}-\mathrm{d})=[(\mathrm{CS} \times \mathrm{IR} \times \mathrm{EF}) / \mathrm{AT}] \times[1 / \mathrm{VF}+1 / \mathrm{PEF}] \times\left[\left(\mathrm{ED}_{c} / \mathrm{BW}_{\mathrm{c}}\right)+\left(\mathrm{ED}_{\mathbf{z}} / \mathrm{BW}_{2}\right)\right]$} \\
\hline \multicolumn{4}{|c|}{ Intake $(\mathrm{pCi})=[\mathrm{CS} \times \mathrm{CF} \times \mathrm{IR} \times \mathrm{EF} \times(1 / \mathrm{VF}+1 / \mathrm{PEF})] \times\left[\mathrm{ED}_{\mathrm{c}}+\mathrm{ED}_{2}\right]$} \\
\hline $\mathrm{CS}=$ & $\begin{array}{l}\text { Concentration in } \\
\text { soil or sediment }\end{array}$ & Chemical-specific (mg/kg; pCi/g) & $\begin{array}{l}\text { Concentration is derived from } \\
\text { sample data }\end{array}$ \\
\hline $\mathrm{IR}=$ & Inhalation rate & $20 \mathrm{~m}^{3} /$ day & $\begin{array}{l}\text { OSWER Directive } \\
\text { (EPA 1991b) }\end{array}$ \\
\hline $\mathrm{CF}=$ & $\begin{array}{l}\text { Conversion } \\
\text { factor }\end{array}$ & $10^{3} \mathrm{~g} / \mathrm{kg}$ & $\begin{array}{l}\text { Necessary to convert to } \\
\text { appropriate units }\end{array}$ \\
\hline $\mathrm{PEF}=$ & $\begin{array}{l}\text { Particulate } \\
\text { emission } \\
\text { factor }\end{array}$ & $4.28 \times 10^{9} \mathrm{~m}^{3} / \mathrm{kg}$ & RAGS Part B (EPA 1991a) \\
\hline $\mathrm{VF}=$ & $\begin{array}{l}\text { Volatilization } \\
\text { factor }\end{array}$ & Chemical specific $\left(\mathrm{m}^{3} / \mathrm{kg}\right)$ & RAGS Part B (EPA 1991a) \\
\hline $\mathrm{EF}=$ & $\begin{array}{l}\text { Exposure } \\
\text { frequency }\end{array}$ & 350 day/year & $\begin{array}{l}\text { OSWER Directive } \\
\text { (EPA 1991b) }\end{array}$ \\
\hline $\mathrm{ED}_{\mathbf{c}}=$ & $\begin{array}{l}\text { Exposure } \\
\text { duration }\end{array}$ & 6 years & $\begin{array}{l}\text { Two-part (child and adult) } \\
\text { residential exposure for a }\end{array}$ \\
\hline $\mathrm{ED}_{\mathbf{2}}$ & & 24 years & $\begin{array}{l}\text { 30-year duration (OSWER } \\
\text { Directive, EPA 1991b) }\end{array}$ \\
\hline $\mathrm{BW}_{\mathrm{c}}=$ & Body weight & $15 \mathrm{~kg}$ & Child (EPA 1991b) \\
\hline $\mathrm{BW}_{\mathrm{a}}$ & & $70 \mathrm{~kg}$ & Adult (EPA 1989a) \\
\hline \multirow[t]{2}{*}{$\mathrm{AT}=$} & Averaging time & 365 days/year $\times 30$ years & $\begin{array}{l}\text { Averaging time } \\
\text { for noncarcinogens } \\
\text { (EPA 1989a, 1991b) }\end{array}$ \\
\hline & & 365 days/year $\times 70$ years & $\begin{array}{l}\text { Averaging time } \\
\text { for carcinogens } \\
\text { (EPA 1989a, 1991b) }\end{array}$ \\
\hline
\end{tabular}


Table 10. On-site residential exposure scenario (external exposure to soil)

\begin{tabular}{|c|c|c|c|}
\hline Variable & & Value used & Explanation/source \\
\hline \multicolumn{4}{|c|}{ Residential external exposure to soil scenario } \\
\hline \multicolumn{4}{|c|}{ Dose $(\mathrm{pCi}-\mathrm{year} / \mathrm{g})=\left[\mathrm{CS} \times(1-\mathrm{Se}) \times \mathrm{Te} \times \mathrm{EF} \times \mathrm{CF} \times\left(\mathrm{ED}_{\mathrm{c}}+\mathrm{ED}_{2}\right)\right]$} \\
\hline $\mathrm{CS}=$ & $\begin{array}{l}\text { Concentration } \\
\text { soil or sediment }\end{array}$ & Chemical-specific (pCi/g) & $\begin{array}{l}\text { Concentration is obtained } \\
\text { from sample data }\end{array}$ \\
\hline $\mathrm{EF}=$ & $\begin{array}{l}\text { Exposure } \\
\text { frequency }\end{array}$ & 350 days/year & $\begin{array}{l}\text { OSWER Directive } \\
\text { (EPA 1991b) }\end{array}$ \\
\hline $\mathrm{CF}=$ & $\begin{array}{l}\text { Conversion } \\
\text { factor }\end{array}$ & $(1 / 365)$ year/days & $\begin{array}{l}\text { Necessary to convert to } \\
\text { appropriate units }\end{array}$ \\
\hline $\mathrm{ED}_{\mathrm{c}}=$ & $\begin{array}{l}\text { Exposure } \\
\text { duration }\end{array}$ & 6 years & $\begin{array}{l}\text { Two-parts (child and adult) } \\
\text { residential exposure } \\
\text { for a 30-year duration }\end{array}$ \\
\hline $\mathrm{ED}_{\mathbf{a}}$ & & 24 years & $\begin{array}{l}\text { (OSWER Directive, } \\
\text { EPA 1991b) }\end{array}$ \\
\hline $\mathrm{Se}=$ & $\begin{array}{l}\text { Gamma shielding } \\
\text { factor (unitless) }\end{array}$ & 0.2 & $\begin{array}{l}\text { RAGS Part B, EPA 1991a; } \\
\text { Sect. 4.1.2 (default value) }\end{array}$ \\
\hline $\mathrm{Te}=$ & $\begin{array}{l}\text { Gamma exposure } \\
\text { time factor } \\
\text { (unitless) }\end{array}$ & 1.0 & $\begin{array}{l}\text { RAGS Part B, EPA 1991a; } \\
\text { Sect. 4.1.2 (default value, } \\
\text { based on } 24 \text { hours/24hours) }\end{array}$ \\
\hline
\end{tabular}


Table 11. On-site residential exposure scenario

(ingestion of homegrown produce pathway)

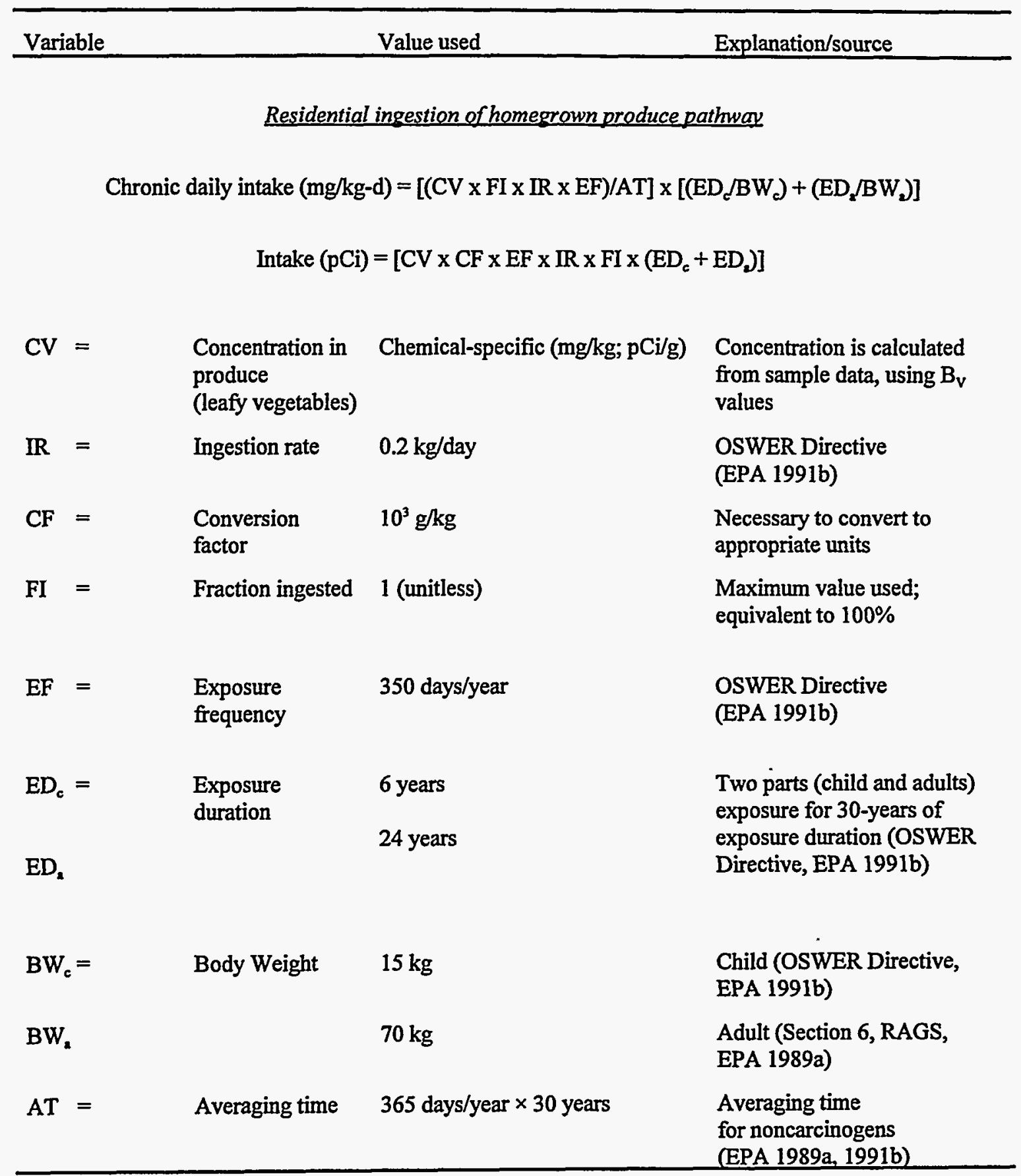


Table 12. On-site residential exposure scenario (ingestion of surface water or groundwater pathway)

\begin{tabular}{|c|c|c|c|}
\hline Variable & & Value used & Explanation/source \\
\hline \multicolumn{4}{|c|}{ Ingestion of surface water or groundwater pathway } \\
\hline \multicolumn{4}{|c|}{ Chronic daily intake $(\mathrm{mg} / \mathrm{kg}-\mathrm{d})=[\mathrm{CW} \times \mathrm{IR} \times \mathrm{EF} \times \mathrm{ED} /(\mathrm{AT} \times \mathrm{BW})]$} \\
\hline \multicolumn{4}{|c|}{ Intake $(\mathrm{pCi})=\mathrm{CW} \times \mathrm{IR} \times \mathrm{EF} \times \mathrm{ED}$} \\
\hline$C W=$ & $\begin{array}{l}\text { Concentration in } \\
\text { water }\end{array}$ & $\begin{array}{l}\text { Chemical-specific (mg/L; } \\
\mathrm{pCi} / \mathrm{L})\end{array}$ & $\begin{array}{l}\text { Concentration is obtained } \\
\text { from sample data }\end{array}$ \\
\hline $\mathrm{IR}=$ & Ingestion rate & 2 L/day & $\begin{array}{l}\text { EPA 1989a; } \\
\text { OSWER Directive } \\
\text { (EPA 1991b) }\end{array}$ \\
\hline $\mathrm{EF}=$ & $\begin{array}{l}\text { Exposure } \\
\text { frequency }\end{array}$ & 350 days/year & $\begin{array}{l}\text { OSWER Directive } \\
\text { (EPA 1991b) }\end{array}$ \\
\hline $\mathrm{ED}_{\mathrm{c}}=$ & $\begin{array}{l}\text { Exposure } \\
\text { duration }\end{array}$ & 30 years & $\begin{array}{l}\text { Residential exposure for a 30- } \\
\text { year duration (OSWER } \\
\text { Directive, EPA 1991b) }\end{array}$ \\
\hline $\mathrm{BW}=$ & Body weight & $70 \mathrm{~kg}$ & $\begin{array}{l}\text { Adult (Section 6, RAGS, } \\
\text { EPA 1989a) }\end{array}$ \\
\hline \multirow[t]{2}{*}{$\mathrm{AT}=$} & Averaging time & 365 days/year $\times \mathrm{ED}$ & $\begin{array}{l}\text { Averaging time } \\
\text { for noncarcinogens } \\
\text { (EPA 1989a, 1991b) }\end{array}$ \\
\hline & & 365 days/year $\times 70$ years & $\begin{array}{l}\text { Averaging time } \\
\text { for carcinogens } \\
\text { (EPA 1989a, 1991b) }\end{array}$ \\
\hline
\end{tabular}


Table 13. On-site residential exposure scenario

(dermal contact with surface water or groundwater during household use pathway)

\begin{tabular}{|c|c|c|c|}
\hline \multicolumn{2}{|l|}{ Variable } & Value used & Explanation/source \\
\hline \multicolumn{4}{|c|}{ Dermal contact with surface water or groundwater during household use pathway } \\
\hline \multicolumn{4}{|c|}{ Chronic daily intake $(\mathrm{mg} / \mathrm{kg}-\mathrm{d})=[\mathrm{CW} \times \mathrm{CF} \times \mathrm{PC} \times \mathrm{ET} \times \mathrm{SA} \times \mathrm{ED} \times \mathrm{EF} /(\mathrm{AT} \times \mathrm{BW})]$} \\
\hline$C W=$ & $\begin{array}{l}\text { Concentration in } \\
\text { water }\end{array}$ & Chemical-specific (mg/L) & $\begin{array}{l}\text { Concentration is obtained } \\
\text { from sample data }\end{array}$ \\
\hline$C F=$ & $\begin{array}{l}\text { Conversion } \\
\text { factors }\end{array}$ & $\mathrm{m} / 100 \mathrm{~cm} \times 1000 \mathrm{~L} / \mathrm{m}^{3}$ & $\begin{array}{l}\text { Necessary to convert } \\
\text { to appropriate units }\end{array}$ \\
\hline $\mathrm{SA}=$ & $\begin{array}{l}\text { Available surface } \\
\text { area }\end{array}$ & $1.94 \mathrm{~m}^{2}$ & $\begin{array}{l}\text { Average total body } \\
\text { surface area for an adult } \\
\text { (Dermal Exposure } \\
\text { Assessment, EPA 1992a) }\end{array}$ \\
\hline $\mathrm{PC}=$ & $\begin{array}{l}\text { Permeability } \\
\text { constant }\end{array}$ & $\begin{array}{l}\text { Chemical-specific } \\
\text { (cm/hour) }\end{array}$ & $\begin{array}{l}\text { Dermal Exposure Assessment } \\
\text { (EPA 1992a) }\end{array}$ \\
\hline $\mathrm{ET}=$ & Exposure time & 0.25 hours/day & $\begin{array}{l}\text { Showering } 15 \text { minutes/day, } \\
\text { Dermal Exposure Assessment } \\
\text { (EPA 1992a) }\end{array}$ \\
\hline $\mathrm{EF}=$ & $\begin{array}{l}\text { Exposure } \\
\text { frequency }\end{array}$ & 350 days/year & $\begin{array}{l}\text { OSWER Directive } \\
\text { (EPA 1991b) }\end{array}$ \\
\hline $\mathrm{ED}=$ & $\begin{array}{l}\text { Exposure } \\
\text { duration }\end{array}$ & 30 years & $\begin{array}{l}\text { Residential exposure } \\
\text { for 30-year duration (OSWER } \\
\text { Directive, EPA 1991b) }\end{array}$ \\
\hline $\mathrm{BW}=$ & Body weight & $70 \mathrm{~kg}$ & $\begin{array}{l}\text { Adult (Section 6, RAGS, } \\
\text { EPA 1989a) }\end{array}$ \\
\hline \multirow[t]{2}{*}{$A T=$} & Averaging time & 365 days/year $\times \mathrm{ED}$ & $\begin{array}{l}\text { Averaging time } \\
\text { for noncarcinogens } \\
\text { (EPA 1989a, 1991b) }\end{array}$ \\
\hline & & 365 days/year $\times 70$ years & $\begin{array}{l}\text { Averaging time } \\
\text { for carcinogens } \\
\text { (EPA 1989a, 1991b) }\end{array}$ \\
\hline
\end{tabular}


Table 14. On-site residential exposure scenario

(inhalation of surface water or groundwater during household use pathway)

\begin{tabular}{|c|c|c|c|c|}
\hline \multicolumn{2}{|c|}{ Variable } & & Value used & Explanation/source \\
\hline \multicolumn{5}{|c|}{ Inhalation of surface water or groundwater during household use pathway } \\
\hline \multicolumn{5}{|c|}{ Chronic daily intake $(\mathrm{mg} / \mathrm{kg}-\mathrm{d})=[(\mathrm{CW} \times \mathrm{IR} \times \mathrm{K} \times \mathrm{EF} \times \mathrm{ED}) /(\mathrm{AT} / \mathrm{BW}))]$} \\
\hline \multicolumn{5}{|c|}{ Intake $(\mathrm{pCi})=\mathrm{CW} \times \mathrm{IR} \times \mathrm{K} \times \mathrm{EF} \times \mathrm{ED}$} \\
\hline $\mathrm{CW}=$ & & $\begin{array}{l}\text { Concentration in } \\
\text { water }\end{array}$ & $\begin{array}{l}\text { Chemical-specific (mg/L; } \\
\text { pCi/L) }\end{array}$ & $\begin{array}{l}\text { Concentration is obtained } \\
\text { from sample data }\end{array}$ \\
\hline $\mathrm{IR}=$ & & Inhalation rate & $20 \mathrm{~m}^{3} /$ day & $\begin{array}{l}\text { Region IV Supplemental } \\
\text { Guidance to RAGS } \\
\text { (EPA 1995) }\end{array}$ \\
\hline $\mathrm{K}=$ & & $\begin{array}{l}\text { Volatilization } \\
\text { factor }\end{array}$ & $0.0005 \times 1000 \mathrm{~L} / \mathrm{m}^{3}$ & (EPA 1989a) \\
\hline $\mathrm{EF}=$ & $=$ & $\begin{array}{l}\text { Exposure } \\
\text { frequency }\end{array}$ & 350 days/year & $\begin{array}{l}\text { OSWER Directive } \\
\text { (EPA 1991b) }\end{array}$ \\
\hline $\mathrm{ED}=$ & & $\begin{array}{l}\text { Exposure } \\
\text { duration }\end{array}$ & 30 years & $\begin{array}{l}\text { Residential exposure for a 30- } \\
\text { year duration (OSWER } \\
\text { Directive, EPA 1991b) }\end{array}$ \\
\hline $\mathrm{BW}_{\mathrm{c}}=$ & & Body weight & $70 \mathrm{~kg}$ & $\begin{array}{l}\text { Adult (Section 6, RAGS, } \\
\text { EPA 1989a) }\end{array}$ \\
\hline \multirow[t]{2}{*}{$\mathrm{AT}=$} & & Averaging time & 365 days/year $\times \mathrm{ED}$ & $\begin{array}{l}\text { Averaging time } \\
\text { for noncarcinogens } \\
\text { (EPA 1989a, 1991b) }\end{array}$ \\
\hline & & & 365 days $/$ year $\times 70$ years & $\begin{array}{l}\text { Averaging time } \\
\text { for carcinogens } \\
\text { (EPA 1989a, 1991b) }\end{array}$ \\
\hline
\end{tabular}


Table 15. On-site future recreational exposure scenario (ingestion of soil)

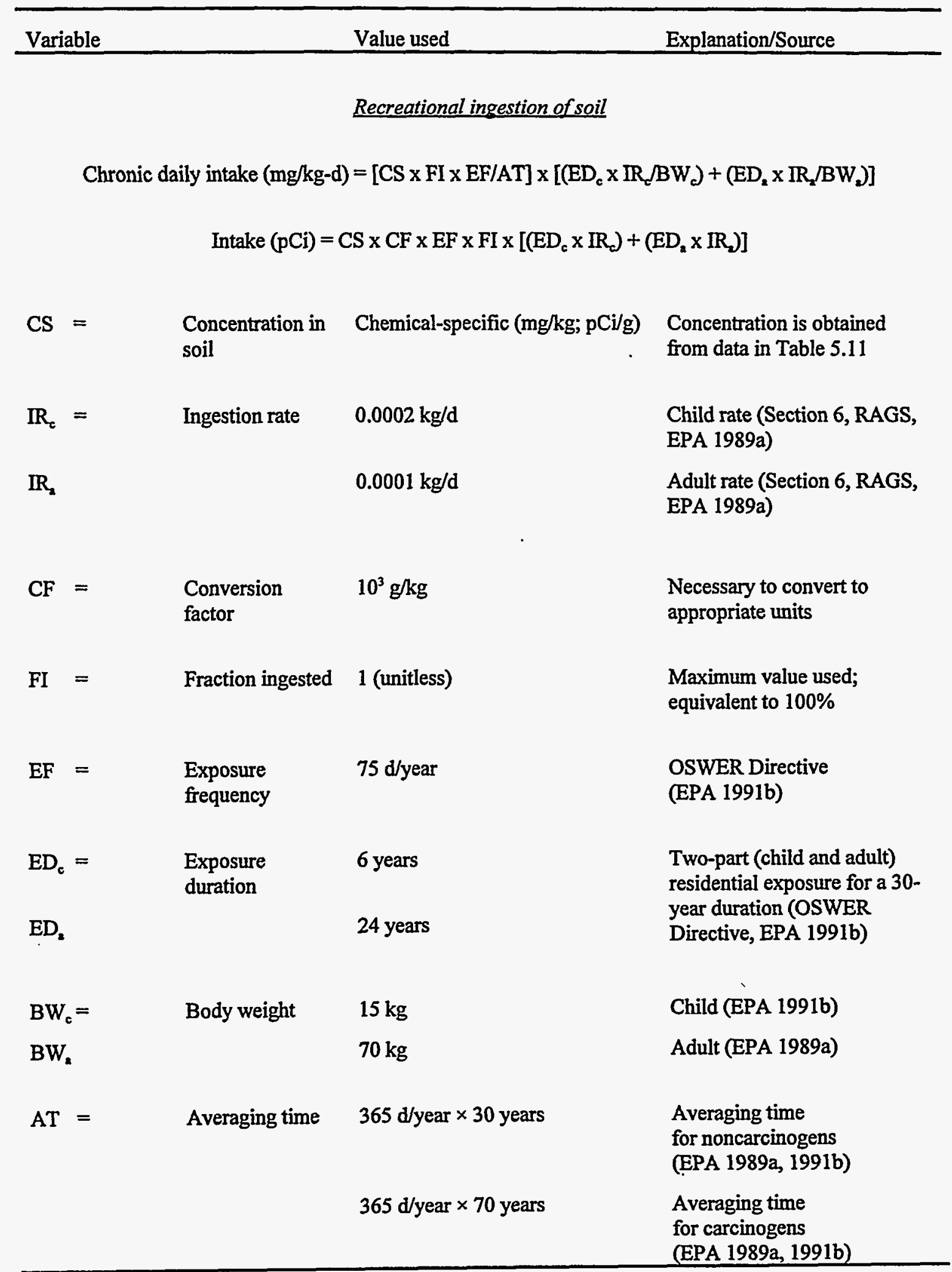


Table 16. On-site future recreational exposure scenario (dermal contact with soil)

\begin{tabular}{|c|c|c|c|}
\hline Variable & & Value used & Explanation/Source \\
\hline \multicolumn{4}{|c|}{ Recreational dermal contact with soil } \\
\hline & \multicolumn{3}{|c|}{$\begin{array}{c}\text { Chronic daily intake }(\mathrm{mg} / \mathrm{kg}-\mathrm{d})=[(\mathrm{CS} \times \mathrm{CF} \times \mathrm{AF} \times \mathrm{ABS} \times \mathrm{EF}) / \mathrm{AT}] \mathrm{x} \\
{\left[\left(\mathrm{SA}_{\mathrm{c}} \times \mathrm{ED}_{\mathrm{e}} / \mathrm{BW}_{\mathrm{c}}\right)+\left(\mathrm{Sa}_{\mathbf{2}} \times \mathrm{ED}_{\mathrm{a}} / \mathrm{BW}_{2}\right)\right]}\end{array}$} \\
\hline $\mathrm{CS}=$ & $\begin{array}{l}\text { Concentration in } \\
\text { soil }\end{array}$ & Chemical-specific (mg/kg) & $\begin{array}{l}\text { Concentration is obtained } \\
\text { from data in Table } 5.11\end{array}$ \\
\hline $\mathrm{CF}=$ & $\begin{array}{l}\text { Conversion } \\
\text { factors }\end{array}$ & $10^{-6} \mathrm{~kg} / \mathrm{mg}$ and $10^{4} \mathrm{~cm}^{2} / \mathrm{m}^{2}$ & $\begin{array}{l}\text { Necessary to convert } \\
\text { to appropriate units }\end{array}$ \\
\hline $\mathrm{SA}_{c}=$ & $\begin{array}{l}\text { Available surface } \\
\text { area }\end{array}$ & $0.182 \mathrm{~m}^{2} / \mathrm{d}$ & $\begin{array}{l}\text { 50th Percentile surface area } \\
\text { for head, hands, forearms, and } \\
\text { lower legs; for a child }\end{array}$ \\
\hline $\mathrm{SA}_{\mathbf{a}}$ & & $0.53 \mathrm{~m}^{2} / \mathrm{d}$ & $\begin{array}{l}\text { and for an adult, respectively } \\
\text { (Dermal Exposure } \\
\text { Assessment, EPA 1992a) }\end{array}$ \\
\hline $\mathrm{AF}=$ & Adherence factor & $1.0 \mathrm{mg} / \mathrm{cm}^{2}$ & $\begin{array}{l}\text { Adherence factor for soil } \\
\text { (EPA Region IV New Interim } \\
\text { Guidance, 2/11/92) }\end{array}$ \\
\hline $\mathrm{ABS}=$ & Absorption factor & $\begin{array}{l}0.001 \text { (unitless) } \\
0.01 \text { (unitless) }\end{array}$ & $\begin{array}{l}\text { Equivalent to } 0.1 \% \\
\text { for inorganics and } 1.0 \% \text { for } \\
\text { organics (EPA Region IV New } \\
\text { Interim Guidance, } 2 / 11 / 92 \text { ) }\end{array}$ \\
\hline $\mathrm{EF}=$ & $\begin{array}{l}\text { Exposure } \\
\text { frequency }\end{array}$ & $75 \mathrm{~d} /$ year & $\begin{array}{l}\text { QSWER Directive } \\
\text { (EPA 1991b) }\end{array}$ \\
\hline $\mathrm{ED}_{\mathrm{c}}=$ & $\begin{array}{l}\text { Exposure } \\
\text { duration }\end{array}$ & 6 years & $\begin{array}{l}\text { Two-part (child and adult) } \\
\text { residential exposure } \\
\text { for a 30-year duration }\end{array}$ \\
\hline $\mathrm{ED}_{3}$ & & 24 years & $\begin{array}{l}\text { (OSWER Directive, } \\
\text { EPA 1991b) }\end{array}$ \\
\hline $\mathrm{BW}_{\mathrm{c}}=$ & Body weight & $15 \mathrm{~kg}$ & $\begin{array}{l}\text { Child (OSWER Directive, } \\
\text { EPA 1991b) }\end{array}$ \\
\hline $\mathrm{BW}_{\mathrm{a}}$ & & $70 \mathrm{~kg}$ & Adult (EPA 1989a) \\
\hline \multirow[t]{2}{*}{$\mathrm{AT}=$} & Averaging time & $365 \mathrm{~d} /$ year $\times 30$ years & $\begin{array}{l}\text { Averaging time } \\
\text { for noncarcinogens } \\
\text { (EPA 1989a, 1991b) }\end{array}$ \\
\hline & & $365 \mathrm{~d} /$ year $\times 70$ years & $\begin{array}{l}\text { Averaging time } \\
\text { for carcinogens } \\
\text { (EPA 1989a, 1991b) } \\
\end{array}$ \\
\hline
\end{tabular}


Table 17. On-site future recreational exposure scenario (inhalation of wind generated dust)

\begin{tabular}{|c|c|c|c|c|}
\hline \multicolumn{2}{|c|}{ Variable } & \multicolumn{2}{|r|}{ Value used } & \multirow[t]{2}{*}{ Explanation/Source } \\
\hline \multicolumn{4}{|c|}{ Recreational inhalation of wind generated dust } & \\
\hline \multicolumn{5}{|c|}{$\begin{array}{c}\text { Chronic daily intake }(\mathrm{mg} / \mathrm{kg}-\mathrm{d})=[\mathrm{CS} \times \mathrm{IR} \times(1 / \mathrm{PEF}+1 / \mathrm{VF}) \times \mathrm{EF} / \mathrm{AT}] \mathrm{x} \\
{\left[\left(\mathrm{ED}_{\mathrm{f}} / \mathrm{BW}_{\mathrm{c}}\right)+\left(\mathrm{ED} \mathrm{D}_{\mathrm{f}} / \mathrm{BW}\right)\right]}\end{array}$} \\
\hline \multicolumn{5}{|c|}{ Intake $(\mathrm{pCi})=\mathrm{CS} \times \mathrm{CF} \times \mathrm{IR} \times(1 / \mathrm{PEF}+1 / \mathrm{VF}) \times \mathrm{EF} \times\left(\mathrm{ED}_{\mathrm{c}}+\mathrm{ED}_{2}\right)$} \\
\hline CS & $=$ & $\begin{array}{l}\text { Concentration in } \\
\text { soil }\end{array}$ & Chemical-specific (mg/kg; pCi/g) & $\begin{array}{l}\text { Concentration is obtained from } \\
\text { data in Table } 5.11\end{array}$ \\
\hline IR & $=$ & Inhalation rate & $20 \mathrm{~m}^{3} / \mathrm{d}$ & $\begin{array}{l}\text { OSWER Directive } \\
\text { (EPA 1991b) }\end{array}$ \\
\hline $\mathrm{CF}$ & $=$ & Conversion factor & $10^{3} \mathrm{~g} / \mathrm{kg}$ & $\begin{array}{l}\text { Necessary to convert to } \\
\text { appropriate units }\end{array}$ \\
\hline $\mathrm{PEF}=$ & & $\begin{array}{l}\text { Particulate } \\
\text { emission } \\
\text { factor }\end{array}$ & $4.28 \mathrm{E}+09 \mathrm{~m}^{3} / \mathrm{kg}$ & RAGS Part B (EPA 1991a) \\
\hline $\mathrm{VF}$ & $=$ & $\begin{array}{l}\text { Volatilization } \\
\text { factor }\end{array}$ & Chemical-specific $\left(\mathrm{m}^{3} / \mathrm{kg}\right)$ & RAGS Part B (EPA 1991a) \\
\hline & $=$ & $\begin{array}{l}\text { Exposure } \\
\text { frequency }\end{array}$ & $75 \mathrm{~d} /$ year & $\begin{array}{l}\text { OSWER Directive } \\
\text { (EPA 1991b) }\end{array}$ \\
\hline $\mathrm{ED}_{\mathrm{c}}=$ & & Exposure duration & 6 years & $\begin{array}{l}\text { Two-part (child and adult) } \\
\text { residential exposure for a } 30 \text {-year }\end{array}$ \\
\hline ED, & & & 24 years & $\begin{array}{l}\text { duration (OSWER Directive, } \\
\text { EPA 1991b) }\end{array}$ \\
\hline $\mathrm{BW}_{\mathrm{c}}=$ & & Body weight & $15 \mathrm{~kg}$ & $\begin{array}{l}\text { Child (OSWER Directive, EPA } \\
\text { 1991b) }\end{array}$ \\
\hline BW, & & & $70 \mathrm{~kg}$ & $\begin{array}{l}\text { Adult (Section 6, RAGS, } \\
\text { EPA 1989a) }\end{array}$ \\
\hline \multirow[t]{2}{*}{ AT } & $=$ & Averaging time & $365 \mathrm{~d} /$ year $\times 30$ years & $\begin{array}{l}\text { Averaging time } \\
\text { for noncarcinogens } \\
\text { (EPA 1989a, 1991b) }\end{array}$ \\
\hline & & & $365 \mathrm{~d} /$ year $\times 70$ years & $\begin{array}{l}\text { Averaging time } \\
\text { for carcinogens } \\
\text { (EPA 1989a; EPA 1991b) }\end{array}$ \\
\hline
\end{tabular}


Table 18. On-site future recreational exposure scenario (external exposure to soil)

\begin{tabular}{|c|c|c|c|c|}
\hline \multicolumn{2}{|c|}{ Variable } & \multicolumn{2}{|r|}{ Value used } & Explanation/Source \\
\hline & & \multicolumn{3}{|c|}{ Recreational external exposure to soil } \\
\hline \multicolumn{5}{|c|}{ Dose $\left(\mathrm{pCi}\right.$-year/g) $=\mathrm{CS} \times(1-\mathrm{Se}) \times \mathrm{Te} \times\left(\mathrm{ED}_{\mathrm{c}}+\mathrm{ED}_{2}\right) \times \mathrm{EF} \times \mathrm{CF}$} \\
\hline CS & $=$ & $\begin{array}{l}\text { Concentration in } \\
\text { soil }\end{array}$ & Chemical-specific (pCi/g) & $\begin{array}{l}\text { Concentration is obtained } \\
\text { from data in Table } 5.11\end{array}$ \\
\hline $\mathrm{ED}_{\mathrm{c}}=$ & & $\begin{array}{l}\text { Exposure } \\
\text { duration }\end{array}$ & 6 years & $\begin{array}{l}\text { Two-part (child and adult) } \\
\text { residential exposure }\end{array}$ \\
\hline $\mathrm{ED}_{\mathbf{z}}$ & & & 24 years & $\begin{array}{l}\text { (OSWER Directive, } \\
\text { EPA 1991b) }\end{array}$ \\
\hline $\mathrm{EF}$ & $=$ & $\begin{array}{l}\text { Exposure } \\
\text { frequency }\end{array}$ & $75 \mathrm{~d} /$ year & $\begin{array}{l}5 \mathrm{~d} / \text { week, } 15 \text { weeks/year } \\
\text { (EPA 1992a) }\end{array}$ \\
\hline $\mathrm{CF}$ & $=$ & $\begin{array}{l}\text { Conversion } \\
\text { factor }\end{array}$ & (1/365) year/d & $\begin{array}{l}\text { Necessary to convert to } \\
\text { appropriate units }\end{array}$ \\
\hline $\mathrm{Se}$ & $=$ & $\begin{array}{l}\text { Gamma shielding } \\
\text { factor (unitless) }\end{array}$ & 0.2 & $\begin{array}{l}\text { RAGS Part B, EPA 1991a; } \\
\text { Sect. 4.1.2 (default value) }\end{array}$ \\
\hline $\mathrm{Te}$ & $=$ & $\begin{array}{l}\text { Gamma exposure } \\
\text { time factor } \\
\text { (unitless) }\end{array}$ & 1.0 & $\begin{array}{l}\text { RAGS Part B, EPA 1991a; } \\
\text { Sect. 4.1.2 (default value, } \\
\text { 24h/24h) }\end{array}$ \\
\hline
\end{tabular}


Table 19. On-site future recreational exposure scenario (ingestion of surface water or groundwater pathway)

\begin{tabular}{|c|c|c|c|}
\hline Variable & & Value used & Explanation/source \\
\hline \multicolumn{4}{|c|}{ Ingestion of surface water or groundwater pathway } \\
\hline \multicolumn{4}{|c|}{ Chronic daily intake $(\mathrm{mg} / \mathrm{kg}-\mathrm{d})=[\mathrm{CW} \times \mathrm{IR} \times \mathrm{EF} \times \mathrm{ET} \times \mathrm{ED}) /(\mathrm{AT} \times \mathrm{BW})]$} \\
\hline \multicolumn{4}{|c|}{ Intake $(p C i)=C W \times I R \times E F \times E T \times E D$} \\
\hline $\mathrm{CW}=$ & $\begin{array}{l}\text { Concentration in } \\
\text { water }\end{array}$ & $\begin{array}{l}\text { Chemical-specific (mg/L; } \\
\mathrm{pCi} / \mathrm{L})\end{array}$ & $\begin{array}{l}\text { Concentration is obtained } \\
\text { from sample data }\end{array}$ \\
\hline $\mathrm{IR}=$ & Ingestion rate & $0.05 \mathrm{~L} /$ hour & $\begin{array}{l}\text { Region IV Supplemental } \\
\text { Guidance to RAGS } \\
\text { (EPA 1995) }\end{array}$ \\
\hline $\mathrm{EF}=$ & $\begin{array}{l}\text { Exposure } \\
\text { frequency }\end{array}$ & 45 days/year & $\begin{array}{l}\text { OSWER Directive } \\
\text { (EPA 1991b) }\end{array}$ \\
\hline $\mathrm{ED}=$ & $\begin{array}{l}\text { Exposure } \\
\text { duration }\end{array}$ & 30 years & $\begin{array}{l}\text { Residential exposure for a } \\
\text { 30-year duration (OSWER } \\
\text { Directive, EPA 1991b) }\end{array}$ \\
\hline $\mathrm{ET}=$ & Exposure time & 1 hour/day & \\
\hline $\mathbf{B W}=$ & Body weight & $70 \mathrm{~kg}$ & $\begin{array}{l}\text { Adult (Section 6, RAGS, } \\
\text { EPA 1989a) }\end{array}$ \\
\hline \multirow[t]{2}{*}{$\mathrm{AT}=$} & Averaging time & 365 days/year $\times \mathrm{ED}$ & $\begin{array}{l}\text { Averaging time } \\
\text { for noncarcinogens } \\
\text { (EPA 1989a, 1991b) }\end{array}$ \\
\hline & & 365 days/year $\times 70$ years & $\begin{array}{l}\text { Averaging time } \\
\text { for carcinogens } \\
\text { (EPA 1989a, 1991b) }\end{array}$ \\
\hline
\end{tabular}


Table 20. On-site future recreational exposure scenario (dermal contact with surface water pathway)

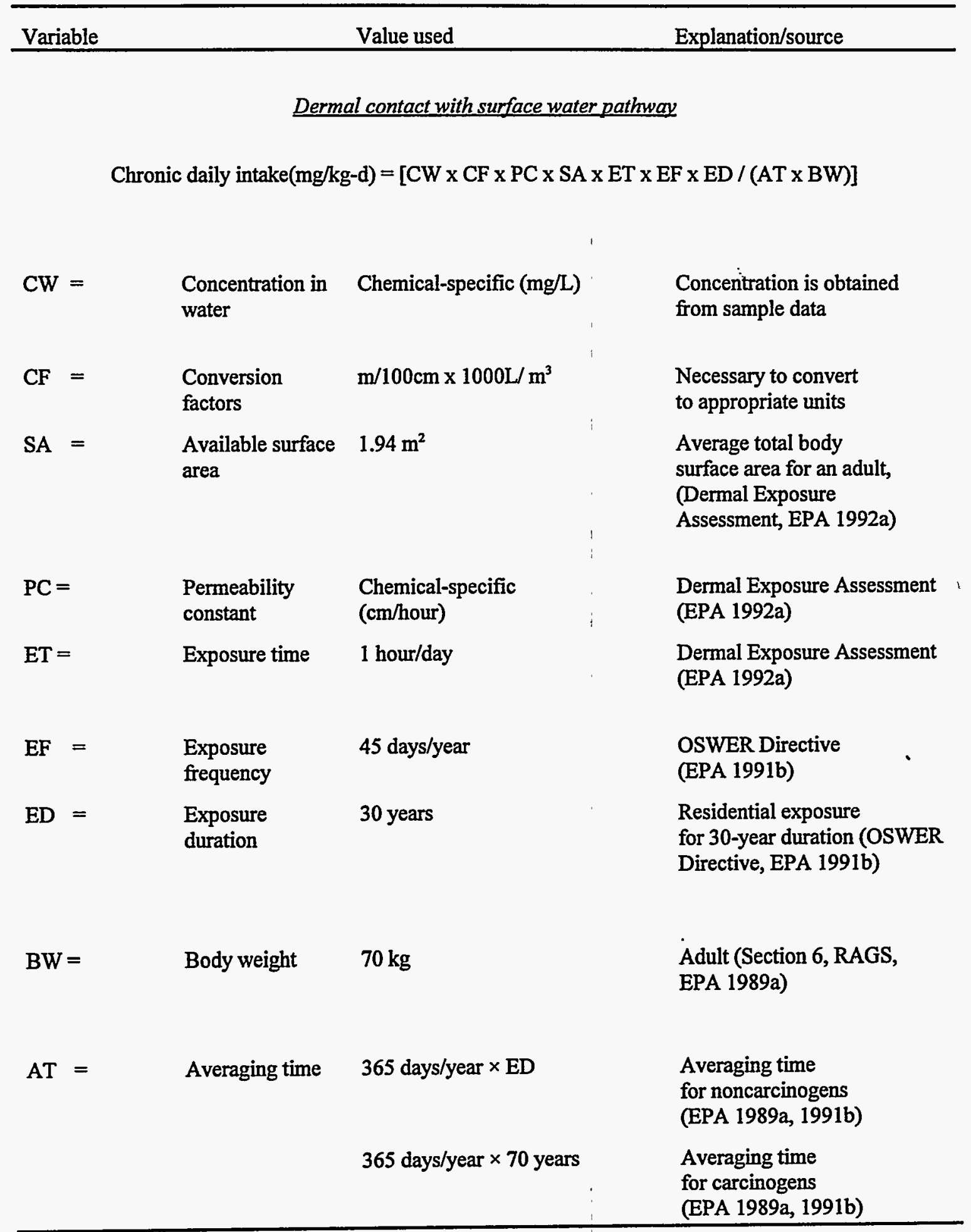


Table 21. On-site future recreational exposure scenario (ingestion of fish pathway)

\begin{tabular}{|c|c|c|c|c|}
\hline \multicolumn{2}{|c|}{ Variable } & - & Value used & Explanation/source \\
\hline \multicolumn{5}{|c|}{ Ingestion of fish pathway } \\
\hline \multicolumn{5}{|c|}{ Chronic daily intake $(\mathrm{mg} / \mathrm{kg}-\mathrm{d})=[\mathrm{CW} \times \mathrm{BF} \times \mathrm{FI} \times \operatorname{IR} \times \mathrm{EF} \times \mathrm{ED} /(\mathrm{AT} \times \mathrm{BW})]$} \\
\hline \multicolumn{5}{|c|}{ Intake $(\mathrm{pCi})=\mathrm{CW} \times \mathrm{BF} \times \mathrm{FI} \times \mathrm{IR} \times \mathrm{EF} \times \mathrm{ED}$} \\
\hline$C W=$ & & $\begin{array}{l}\text { Concentration in } \\
\text { water }\end{array}$ & $\begin{array}{l}\text { Chemical-specific (mg/L or } \\
\text { pCi/L) }\end{array}$ & $\begin{array}{l}\text { Concentration is derived from } \\
\text { sąmple data }\end{array}$ \\
\hline $\mathrm{BF}=$ & $=$ & $\begin{array}{l}\text { Bioaccumulation } \\
\text { factor }\end{array}$ & Chemical-specific $(\mathrm{L} / \mathrm{kg})$ & Factor obtained from literature \\
\hline $\mathbf{I R}=$ & $=$ & Ingestion rate & $0.054 \mathrm{~kg} / \mathrm{day}$ & $\begin{array}{l}\text { OSWER Directive } \\
\text { (EPA 1991b, 1995a) }\end{array}$ \\
\hline $\mathrm{EF}=$ & $=$ & $\begin{array}{l}\text { Exposure } \\
\text { frequency }\end{array}$ & 48 days/year & RAGS (EPA 1989a) \\
\hline $\mathrm{ED}=$ & $=$ & $\begin{array}{l}\text { Exposure } \\
\text { duration }\end{array}$ & 30 years & $\begin{array}{l}\text { Residential exposure for a 30- } \\
\text { year duration (OSWER } \\
\text { Directive, EPA 1991b) }\end{array}$ \\
\hline $\mathrm{FI}=$ & & Fraction Ingested & 1 unitless & \\
\hline $\mathrm{BW}=$ & & Body weight & $70 \mathrm{~kg}$ & Adult (EPA 1991b) \\
\hline \multirow[t]{2}{*}{$\mathrm{AT}=$} & $=$ & Averaging time & 365 days/year $\times \mathrm{ED}$ & $\begin{array}{l}\text { Averaging time } \\
\text { for noncarcinogens } \\
\text { (EPA 1989a, 1991b) }\end{array}$ \\
\hline & & & 365 days/year $\times 70$ years & $\begin{array}{l}\text { Averaging time } \\
\text { for carcinogens } \\
\text { (EPA 1989a, 1991b) }\end{array}$ \\
\hline
\end{tabular}




\subsubsection{Chronic daily intake calculations for the ingestion of produce}

Another route of exposure includes residential ingestion of produce grown in contaminated dry sediment at WAG 2 . Table 11 presents the chronic daily intake equations and corresponding parameters used for the ingestion of produce. In this subsection, the concentrations of contaminants used in the chronic daily intake calculations were derived using bioconcentration factors. To calculate the chronic daily intake for ingestion of produce, an estimate of the contaminant concentrations in produce was determined for each of the identified reaches.

The plant concentration due to root uptake, $C_{p}$ is estimated by

$$
C_{r}=B_{v} C_{s}
$$

where $\boldsymbol{B}_{v}$ is the soil-to-plant transfer coefficient which is dimensionless, and $\mathbf{C}_{\mathbf{s}}$ is the concentration in the floodplain soil and sediment in $\mathrm{mg} / \mathrm{kg}$ or $\mathrm{pCi} / \mathrm{g}$.

\subsubsection{Chronic Daily Intake Calculations for the Recreational Land Use Scenario}

The exposure assumptions associated with all exposure routes included in the recreational land use scenario are listed in Tables 15 to 21 . For the hypothetical future recreational land use scenario, the defaults as provided by EPA guidance are used to calculate the chronic daily intakes for a person exposed for 6 years as a child and 24 years as an adult. The exposure frequency to soil contaminants in the WAG 2 sediment was assumed to be 8 days/year for an exposure duration of 30 years. Parameters are recreational default values provided by EPA (EPA 1991.b, 1991c) and LMES (1996a) guidance. Parameters for the fish ingestion scenario also reflect EPA guidance.

\subsubsection{Derivation of Exposure Concentration}

The location and number of media samples can affect the contaminants identified and the calculated exposure concentration. Higher densities of collected samples generally lead to more certain results for the exposure concentration. The exposure concentration recommended by EPA for calculating the RME is the minimum of the maximum of the range and the upper 95th confidence limit of the mean.

\subsubsection{Exposure concentration for analytical surface water and floodplain soil/sediment}

The first step in determining the exposure concentration is to determine the frequency of detection for each analyte. Half of the detection limit is used as a proxy value for all nondetected values. For analytes that have at least one detected value, a statistical test (Shapiro-Wilks test) is performed to determine if a normal or lognormal distribution best fits the concentration distribution. If the distribution is lognormal, then nondetects are reassigned a value between $\mathbf{0}$ and the detection limit based on the Lifereg SAS procedure which attempts to extrapolate the lower tail of the lognormal distribution. Based on the results of the Shapiro-Wilks test, the analyte's mean concentration and the upper 95 th confidence limit on the mean concentration are calculated appropriately (i.e., based on a normal or lognormal distribution). The maximum detected concentration is then compared against the upper 95th confidence limit; the smaller of these two measures is used as the analyte's exposure concentration. This method can moderately overestimate the exposure concentration. In addition, 
when the resulting individual contaminant risks are summed, the compounding conservatism will result in an overestimate of the upper 95th confidence limit of the summed risk.

\subsubsection{Exposure concentration for Ultrasonic Ranging and Data Systems walkover data}

The Ultrasonic Ranging and Data Systems data set was segregated according to the six reaches identified for the RI. Given the large number of data points available for each reach and all values being detected, the upper 95th confidence limit on the mean was used in developing the exposure concentration. The results of the walkover are given in microRoentgen per hour. Roentgen are converted to risk through the use of an exposure conversion factor of 0.877 Roentgen/Rad (Cember 1987) and an electron dose conversion factor of $0.8 \mathrm{Rad} / \mathrm{Rem}$ (Jacobs et al. 1986). The dose in millirem is converted to risk through the ICRP 60 conversion factor of $7.3 \times 10^{-7} / \mathrm{mrem}$ (ICRP 1991). Exposure factors for each land use scenario are those given for the external exposure pathway in the previous section.

\subsubsection{Exposure concentration for HEDOSE modeled dose rates}

The HEDOSE model was developed for the analysis of the WAG 2 sediment conducted by Ford et al. (1996). It incorporates the effects of shielding by calculating a series of plane sources at various depths based on the ${ }^{137} \mathrm{Cs}$ and ${ }^{60} \mathrm{Co}$ concentrations that are present in each layer. The effects of the shielding provided by the depth above the layer and the density of the soil are then accounted for and the contribution from each layer is summed. Dose to critical organs is then calculated based on tabulated values in Eckermann and Ryman (1993) for ${ }^{137} \mathrm{Cs},{ }^{137} \mathrm{Ba}$ (the decay product of ${ }^{137} \mathrm{Cs}$ ), and for ${ }^{60} \mathrm{Co}$. The Eckermann and Ryman dose coefficients incorporate the effects of the angular distribution and energy of the gamma-emitters in the soil and the transport and energy deposition into the body and provide a calculation of an organ or tissue dose for ${ }^{137} \mathrm{Cs},{ }^{137} \mathrm{Ba}$, and ${ }^{60} \mathrm{Co}$. The resulting total body dose is converted to a risk using the ICRP 60 conversion factor presented in the previous section.

\section{RISK CHARACTERIZATION}

The purpose of the risk characterization is to integrate and summarize the risk information generated for each of the land use scenarios. This represents the final step in the human health risk assessment process. Potential carcinogenic effects are characterized by estimating the probability that an individual will develop cancer over a lifetime from projected intakes (and exposures) and chemical-specific dose-response data (i.e., slope factors). Potential noncarcinogenic (systemic) effects are characterized by comparing projected intakes of contaminants to toxicity values (i.e., reference doses). The numerical risk or hazard quotient estimates presented in this section must be interpreted in the context of the uncertainties and assumptions associated with the risk assessment process and the data upon which the risk estimates are based.

\subsection{EVALUATION OF CARCINOGENS AND NONCARCINOGENS}

Carcinogenic risk and noncarcinogenic hazard potential for carcinogens and noncarcinogens, respectively, are calculated for the WAG 2 sediment COPCs. These risks and hazard potential are based upon EPA-approved or -suggested slope factors, reference concentrations, and reference doses. The slope factor is based on an estimate of the incremental lifetime cancer risk which equates to 
incidence per unit of exposure, and the reference dose is a level of exposure (threshold) below which no noncarcinogenic adverse health effects are expected to occur.

Cancer risk is an estimate of the incremental probability of developing excess cancer over a lifetime (EPA 1989), above and beyond the normal (unavoidable) incidence observed in the general population. The risk estimates for carcinogens are calculated by multiplying the EPA-approved slope factors for inorganics, organics, and radionuclides by an estimate of the actual exposure to these contaminants (i.e., chronic daily intake and/or dose) via the different pathways of ingestion, inhalation, dermal contact, or external exposure. The risk equation (intake $\times$ slope factor $=$ risk) is based on the assumption that there is a linear relationship between dose and response (cancer incidence) (EPA 1989). The assumption that dose-response is linear is reliable only for predicting risk at low exposure levels; therefore, the application of the previous equation is limited to risks below 1E-02. At high exposure levels ( $21 \mathrm{E}-02$ ), which is frequently the case for WAG 2 due to the high level of activity associated with radionuclides in various media, the one-hit equation [risk=1 - exponential(chronic daily intake $\times$ slope factor)] was applied to estimate risk (EPA 1989).

For this assessment, the one-hit risk equation was applied for ${ }^{90} \mathrm{Sr},{ }^{3} \mathrm{H},{ }^{137} \mathrm{Cs}$, and ${ }^{60} \mathrm{Co}$ at locations where the contaminant risk exceeded 1.0E-2. No other contaminants exceeded 1.0E-4 risk. Because some risks were calculated using the one-hit equation and others with the linear equation, the sum of the risk numbers mentioned in the text for individual analytes or exposure routes may not equal the total scenario risk referenced. This may also occur as a result of rounding associated with the estimation of cancer risks that are typically reported to one significant figure.

The hazard quotient estimates for noncarcinogens are calculated by determining the ratio of the chronic daily intake for ingestion, inhalation, and dermal contact of a contaminant to the contaminant-specific reference toxicity value (reference dose, reference concentration). The hazard quotient is based on the assumption that below a given level of chronic exposure (i.e., the reference dose) populations are unlikely to experience adverse health effects.

To estimate the potential risk to human health from all contaminants in a particular pathway, the risks are summed and the hazard quotient are summed for all contaminants in that pathway [i.e., a cumulative risk (total pathway risk) or a cumulative hazard index (total of pathway hazard quotient) is determined from exposure to all contaminants (EPA 1989)]. In addition, an overall cumulative risk due to the site contaminants can be determined by summing the risks or hazard quotients from all analytes from all of the pathways associated with a specific land use. Summations are conducted separately for chemicals (either carcinogens, noncarcinogens, or radionuclides.)

The constituents detected in the WAG 2 media and listed as COPCs were evaluated within the context of EPA-approved guidelines (EPA 1989) which describe three regions of interest for carcinogenic risk (risk $<1.0 \mathrm{E}-06$, no concern; risk between 1.0E-06 and 1.0E-04, target risk range; and risk $\geq 1.0 \mathrm{E}-04$, concern) and two areas of interest in terms of noncarcinogenic/systemic toxicity (hazard index $<1.0$, target range, and hazard index $\geq 1.0$, concern). These boundaries allow an optional screening analysis to be performed to prioritize the large number of detected chemicals. The COCs that contribute to risks that exceed the target risk range in the risk assessment in each reach within WAG 2 were identified based on the total pathway risk or hazard index in an effort to limit the number of chemicals to be considered. That is, if the total pathway risk or hazard index exceeds the target range (total pathway risk $\geq 1 \mathrm{E}-04$ or total pathway hazard quotient $\geq 1.0$ ), then all COPCs with individual risks $\geq 1 \mathrm{E}-06$ or a hazard quotient $\geq 0.1$ are considered COCs. 


\subsection{RISK SUMMARY BY MEDIA}

The risk characterization for the assessment includes potential risks determined as a result of exposure to floodplain soils and sediments and WAG 2 surface water. The risk estimates associated with exposure to the floodplain soil, sediment, and surface water are presented by toxic effect (carcinogenic or noncarcinogenic) and by land use (residential, recreational, and industrial).

\subsubsection{Sediment/Floodplain Soil}

\subsubsection{On-site sediment/floodplain soil risk}

The floodplain soil and sediment data used to conduct this assessment are divided into the following six areas or reaches: (1) IHP, which includes the intermediate holding pond area; (2) LWOC, which includes White Oak Lake; (3) MWOC, the lower portion of White Oak Creek above the confluence of White Oak Creek and Melton Branch; (4) LMBC, the lower portion of Melton Branch above the confluence; (5) MMBC, Melton Branch in the vicinity of WAG 5, and (6) UMBC, the upper portion of Melton Branch. In addition, the data collected for each reach was divided into the 2 categories: surface and subsurface. Surface floodplain soil and sediment includes all data collected from a depth of 0 to $15 \mathrm{~cm}$ below the ground surface. Subsurface floodplain soil and sediment includes the remaining data collected from a depth of $15 \mathrm{~cm}$ and greater below the surface soil.

Residential scenario-carcinogenic results. The carcinogenic risks to a future on-WAG resident were determined for exposure to contaminated floodplain soils and sediment via (1) incidental ingestion of sediment, (2) dermal contact with the sediment, (3) inhalation of wind-generated dust and particulates, (4) external exposure to radionuclides, and (5) ingestion of produce. Table 22 provides a summary of the risk estimates for the exposure of a future resident to the WAG 2 carcinogenic COCs in the sediment and the floodplain soil for the surface data $(0$ to $15 \mathrm{~cm}$ below the ground surface). The tables include the individual risk estimates for each exposure pathway and the total risk from all the exposure pathways (sum of the individual exposure pathways). In addition, the contaminant, along with the risk estimate and exposure pathway, which has the greatest contribution to the overall carcinogenic risk, is also included in the summary table.

Total risk to the hypothetical resident is due almost exclusively from external exposure to radionuclides. The contaminants detected in the reaches in WAG 2 which drive the risk values for external exposure are ${ }^{137} \mathrm{Cs}$ and ${ }^{60} \mathrm{Co} .{ }^{137} \mathrm{Cs}$ is the major contaminant for the IHP, LWOC, LMBC, and MWOC reaches, while ${ }^{60} \mathrm{Co}$ is the primary contaminant for the $\mathrm{MMBC}$ and $\mathrm{UMBC}$ areas. ${ }^{137} \mathrm{Cs}$ has a half-life of 30.2 years, and ${ }^{60} \mathrm{Co}$ has a half-life of 5.3 years; therefore, future risk can be expected to decrease as a function of the half-life. At a risk of 1.0E-2, it takes more than six half-lives for the contaminant risk to decay to the target risk of below $1.0 \mathrm{E}-4$; for ${ }^{137} \mathrm{Cs}$ this would be more than 180 years, while for ${ }^{60} \mathrm{Co}$ it would be about 40 years. 
Table 22. Summary of carcinogenic risk for WAG 2 sediment data based on residential land use scenario ( 0 to $15 \mathrm{~cm}$ depth samples)

\begin{tabular}{|c|c|c|c|c|c|c|c|}
\hline Reach & $\begin{array}{c}\text { Ingestion } \\
\text { of } \\
\text { sediment }\end{array}$ & $\begin{array}{l}\text { Ingestion } \\
\text { of produce }\end{array}$ & $\begin{array}{c}\text { Dermal } \\
\text { exposure }\end{array}$ & Inhalation & $\begin{array}{l}\text { External } \\
\text { exposure }\end{array}$ & Total risk & Summary \\
\hline IHP & $3.4 \mathrm{E}-4$ & $6.2 \mathrm{E}-2$ & $1.1 \mathrm{E}-5$ & $3.5 \mathrm{E}-7$ & 2.7E-1 & $3.2 \mathrm{E}-1$ & $\begin{array}{l}{ }^{137} \mathrm{Cs:} \\
2.7 \mathrm{E}-1 \text { for } \\
\text { external } \\
\text { exposure }\end{array}$ \\
\hline LWOC & $8.3 \mathrm{E}-5$ & $1.5 \mathrm{E}-2$ & $4.2 \mathrm{E}-6$ & $2.4 \mathrm{E}-7$ & $5.8 \mathrm{E}-2$ & $7.2 \mathrm{E}-2$ & $\begin{array}{l}{ }^{137} \mathrm{Cs}: \\
5.2 \mathrm{E}-2 \text { for } \\
\text { external } \\
\text { exposure }\end{array}$ \\
\hline LMBC & $3.2 \mathrm{E}-5$ & $6.4 \mathrm{E}-3$ & - & 1.1E-7 & $3.6 \mathrm{E}-2$ & $4.2 \mathrm{E}-2$ & $\begin{array}{l}{ }^{137} \mathrm{Cs}: \\
3.2 \mathrm{E}-2 \text { for } \\
\text { external } \\
\text { exposure }\end{array}$ \\
\hline MWOC & $4.8 \mathrm{E}-5$ & $7.3 \mathrm{E}-3$ & $1.6 \mathrm{E}-5$ & $8.6 \mathrm{E}-8$ & $2.9 \mathrm{E}-2$ & $3.6 \mathrm{E}-2$ & $\begin{array}{l}{ }^{137} \mathrm{Cs}: \\
2.7 \mathrm{E}-2 \text { for } \\
\text { external } \\
\text { exposure }\end{array}$ \\
\hline MMBC & $1.7 \mathrm{E}-3$ & $4.0 \mathrm{E}-1$ & - & $1.6 \mathrm{E}-7$ & $5.5 \mathrm{E}-3$ & $4.1 \mathrm{E}-1$ & $\begin{array}{l}{ }^{90} \mathrm{Sr}: \\
4.0 \mathrm{E}-1 \text { for } \\
\text { produce }\end{array}$ \\
\hline UMBC & $4.6 \mathrm{E}-6$ & 8.7E-4 & & $1.9 \mathrm{E}-7$ & $4.3 \mathrm{E}-2$ & $4.3 \mathrm{E}-2$ & $\begin{array}{l}{ }^{60} \mathrm{Co:} \\
4.3 \mathrm{E}-2 \text { for } \\
\text { external } \\
\text { exposure }\end{array}$ \\
\hline
\end{tabular}

For the surface sediment data, the risk due to external exposure for the major contaminant of concern $\left({ }^{137} \mathrm{Cs}\right.$ or $\left.{ }^{60} \mathrm{Co}\right)$ at the reaches in WAG 2 varies from $2.7 \mathrm{E}-1$ to $4.7 \mathrm{E}-3$, while the total risk from all exposure pathways and COCs varies from $3.2 \mathrm{E}-1$ to $3.6 \mathrm{E}-2$ for these same reaches. The only exception is in reach $\mathrm{MMBC}$ where the risk is due mainly to ${ }^{90} \mathrm{Sr}$ and the ingestion of produce pathway. Therefore, the carcinogenic risks associated with the exposure pathways besides the external exposure pathway have virtually little contribution to the total risk at the reaches defined for WAG 2 other than MMBC. Although it does not drive the carcinogenic risk for the surface sediment of reach MMBC, the external exposure to radionuclides pathway represents risks that exceed the target risk range, with a risk value of $5.5 \mathrm{E}-3$.

Although it generally presents less risk than the external exposure pathway, the ingestion of produce pathway represents risks in exceedance of the target range to a future resident at all of the reaches. The risk values for ingestion of produce at the other reaches vary from $4.0 \mathrm{E}-1(\mathrm{MMBC})$ to 8.7E-4 (UMBC). These values represent risk values above the target risk range for future residents because they are greater than $1.0 \mathrm{E}-04$.

Recreational scenario-carcinogenic results. The carcinogenic risks to a future recreational user were determined for exposure to contaminated sediment in floodplain soil and sediments via 
(1) incidental ingestion, (2) dermal contact, (3) inhalation, and (4) external exposure to radionuclides. Table 23 provides a summary of the risk estimates for the exposure of a recreational user to the WAG 2 carcinogenic COPCs in the floodplain soils and sediments.

Table 23. Summary of carcinogenic risk for WAG 2 sediment data based on recreational land use scenario ( 0 to $15 \mathrm{~cm}$ depth samples)

\begin{tabular}{|c|c|c|c|c|c|c|}
\hline Reach & $\begin{array}{l}\text { Ingestion } \\
\text { of } \\
\text { sediment }\end{array}$ & $\begin{array}{c}\text { Dermal } \\
\text { exposure }\end{array}$ & $\begin{array}{c}\text { Inhalation of } \\
\text { sediment }\end{array}$ & $\begin{array}{l}\text { External } \\
\text { exposure }\end{array}$ & Total risk & Summary \\
\hline IHP & 3.1E-6 & $2.3 E-6$ & 3.1E-9 & $2.8 \mathrm{E}-3$ & $2.8 \mathrm{E}-3$ & $\begin{array}{l}{ }^{137} \mathrm{Cs}: \\
2.8 \mathrm{E}-3 \text { for } \\
\text { external } \\
\text { exposure }\end{array}$ \\
\hline LWOC & 7.4E-7 & $8.9 \mathrm{E}-7$ & $2.2 \mathrm{E}-9$ & $5.4 \mathrm{E}-4$ & $5.4 \mathrm{E}-4$ & $\begin{array}{l}{ }^{137} \mathrm{Cs:} \\
4.7 \mathrm{E}-4 \text { for } \\
\text { external } \\
\text { exposure }\end{array}$ \\
\hline LMBC & $2.8 \mathrm{E}-7$ & - & $9.4 \mathrm{E}-10$ & $3.3 \mathrm{E}-4$ & $3.3 \mathrm{E}-4$ & $\begin{array}{l}{ }^{137} \mathrm{Cs}: \\
2.9 \mathrm{E}-4 \text { for } \\
\text { external } \\
\text { exposure }\end{array}$ \\
\hline MWOC & 4.3E-7 & $3.3 \mathrm{E}-6$ & 7.7E-10 & $2.6 \mathrm{E}-4$ & $2.6 \mathrm{E}-4$ & $\begin{array}{l}{ }^{137} \mathrm{Cs}: \\
2.5 \mathrm{E}-4 \text { for } \\
\text { external } \\
\text { exposure }\end{array}$ \\
\hline MMBC & $1.5 \mathrm{E}-05$ & - & $1.4 \mathrm{E}-9$ & $4.9 \mathrm{E}-5$ & $6.4 \mathrm{E}-5$ & $\begin{array}{l}{ }^{60} \mathrm{Co}: \\
4.9 \mathrm{E}-5 \text { for } \\
\text { external } \\
\text { exposure }\end{array}$ \\
\hline UMBC & 4.1E-8 & & 1.7E-9 & $3.9 E-4$ & $3.9 \mathrm{E}-4$ & $\begin{array}{l}{ }^{60} \mathrm{Co}: \\
3.9 \mathrm{E}-4 \text { for } \\
\text { external } \\
\text { exposure }\end{array}$ \\
\hline
\end{tabular}

The table includes the individual risk estimates for each exposure pathway and the total risk from all the exposure pathways (sum of the individual exposure pathways). In addition, the contaminant, along with the risk estimate and exposure pathway, which contributes the most to the overall carcinogenic risk, is also included. As in the case of the residential land use scenario, total risk to the trespasser is due almost exclusively from external exposure to radionuclides. The contaminants that drive the risk values for external exposure are ${ }^{137} \mathrm{Cs}$ and ${ }^{60} \mathrm{Co} .{ }^{137} \mathrm{Cs}$ is the major contaminant for the IHP, LWOC, LMBC, and MWOC reaches, while ${ }^{60} \mathrm{Co}$ is the primary contaminant for the $\mathrm{MMBC}$ and UMBC areas. For surface floodplain soil and sediment data, the risk due to external exposure for the major contaminant of concern (either ${ }^{137} \mathrm{Cs}$ or ${ }^{60} \mathrm{Co}$ ) at the reaches in WAG 2 varies from $2.8 \mathrm{E}-3$ to 4.9E-5, while the total risk from all exposure pathways varies from $2.8 \mathrm{E}-3$ to $6.4 \mathrm{E}-5$ for these same reaches. Therefore, the carcinogenic risks associated with the exposure pathways besides the external exposure pathway have little contribution to the total risk at a reach within WAG 2. 
Most of the carcinogenic risk values for the ingestion pathway and all of the risk values for the inhalation of wind-generated sediment for recreational land use are less than 1.0E-6 and are therefore of no concern. In addition, dermal contact with sediments in the floodplain soils also does not present a concern since the risk values for this pathway are all less than 1.0E-6.

Industrial scenario-carcinogenic results. The carcinogenic risks to a future industrial worker were determined for exposure to contaminated floodplain soils and sediment via (1) incidental ingestion, (2) dermal contact, (3) inhalation of wind-generated particulates, and (4) external exposure to radionuclides. Table 24 provides a summary of the risk estimates for the exposure of an industrial worker to the WAG 2 carcinogenic COPCs in the surface floodplain soils and sediments. The table includes the individual risk estimates for each exposure pathway and the total risk from all the exposure pathways. The contaminant, along with the risk estimate and exposure pathway (for this contaminant), which has the greatest contribution to the overall carcinogenic risk, is also included in the summary tables. As in the case of the other land use scenarios, total risk to the industrial worker is due almost exclusively to the external exposure to radionuclides pathway. The contaminants that drive the risk values for external exposure are ${ }^{137} \mathrm{Cs}$ and ${ }^{60} \mathrm{Co} .{ }^{137} \mathrm{Cs}$ is the major contaminant for the IHP, LWOC, LMBC, and MWOC reaches, while ${ }^{60} \mathrm{Co}$ is the primary contaminant for the MMBC and UMBC areas.

Table 24. Summary of carcinogenic risk for WAG 2 sediment data based on industrial land use scenario ( 0 to $15 \mathrm{~cm}$ depth samples)

\begin{tabular}{|c|c|c|c|c|c|c|}
\hline Reach & $\begin{array}{c}\text { Ingestion of } \\
\text { sediment }\end{array}$ & $\begin{array}{c}\text { Dermal } \\
\text { exposure }\end{array}$ & $\begin{array}{c}\begin{array}{c}\text { Inhalation of } \\
\text { sediment }\end{array} \\
\end{array}$ & $\begin{array}{l}\text { External } \\
\text { exposure }\end{array}$ & Total risk & Summary \\
\hline IHP & $8.4 \mathrm{E}-5$ & $3.8 \mathrm{E}-6$ & 2.1E-7 & $6.1 \mathrm{E}-2$ & $6.1 \mathrm{E}-2$ & $\begin{array}{l}{ }^{137} \mathrm{Cs}: \\
6.0 \mathrm{E}-1 \text { for } \\
\text { external } \\
\text { exposure }\end{array}$ \\
\hline LWOC & $2.0 \mathrm{E}-5$ & $1.5 \mathrm{E}-6$ & $1.4 \mathrm{E}-7$ & $1.2 \mathrm{E}-2$ & $1.2 \mathrm{E}-02$ & $\begin{array}{l}{ }^{137} \mathrm{Cs}: \\
1.0 \mathrm{E}-2 \text { for } \\
\text { external } \\
\text { exposure }\end{array}$ \\
\hline LMBC & $7.9 \mathrm{E}-6$ & - & $6.3 \mathrm{E}-8$ & 7.3E-3 & 7.3E-3 & $\begin{array}{l}{ }^{137} \mathrm{Cs}: \\
6.5 \mathrm{E}-3 \text { for } \\
\text { external } \\
\text { exposure }\end{array}$ \\
\hline MWOC & $9.7 \mathrm{E}-6$ & $5.5 \mathrm{E}-6$ & $5.1 E-8$ & $5.8 \mathrm{E}-3$ & $5.8 \mathrm{E}-3$ & $\begin{array}{l}{ }^{137} \mathrm{Cs}: \\
5.5 \mathrm{E}-3 \text { for } \\
\text { external } \\
\text { exposure }\end{array}$ \\
\hline
\end{tabular}


Table 24. (continued)

\begin{tabular}{lcccccc}
\hline Reach & $\begin{array}{c}\text { Ingestion of } \\
\text { sediment }\end{array}$ & $\begin{array}{c}\text { Dermal } \\
\text { exposure }\end{array}$ & $\begin{array}{c}\text { Inhalation of } \\
\text { sediment }\end{array}$ & $\begin{array}{c}\text { External } \\
\text { exposure }\end{array}$ & Total risk & Summary \\
\hline MMBC & $4.1 \mathrm{E}-4$ & & $9.4 \mathrm{E}-8$ & $1.1 \mathrm{E}-3$ & $1.5 \mathrm{E}-3$ & $\begin{array}{l}{ }^{60} \mathrm{Co:} \\
9.3 \mathrm{E}-4 \text { for } \\
\end{array}$ \\
& & & & & $\begin{array}{l}\text { external } \\
\text { exposure }\end{array}$ \\
& & & & & $8.6 \mathrm{E}-3$ & $\begin{array}{l}{ }^{60} \mathrm{Co:} \\
8.6 \mathrm{E}-3 \text { for } \\
\text { external } \\
\text { exposure }\end{array}$ \\
\hline
\end{tabular}

The carcinogenic risk results range from $6.1 \mathrm{E}-2$ to $1.5 \mathrm{E}-3$ with all of the reaches exceeding the target risk range. The carcinogenic risks associated with the exposure pathways besides the external exposure pathway have virtually no contribution to the total risk at a reach within WAG 2 . The ingestion pathway at MMBC does exceed the target risk range while the majority of the other pathways, with the exception of inhalation, fall within the target risk range.

Summary-carcinogenic results. Table 25 provides a summary of the total carcinogenic risk (sum of all exposure pathways) associated with each land use scenario for all of the reaches in WAG 2. The table includes risk values for subsurface and surface data. For the residential land use scenario, the carcinogenic risk at all of the reaches is above the target risk range because all risk values are greater than 1.0E-04. The risk values for subsurface and surface data for the residential land use scenario are within an order of magnitude of each other so the difference is not too significant. Floodplain soils and sediment at all reaches present high human health risks to receptors under the residential scenario (risk $\geq 1.0 \mathrm{E}-4$ ); the surface sediments in reach IHP present the greatest human health risk for future residents, with a risk value of $7.8 \mathrm{E}-1$.

The recreational risk values for all of the reaches vary from $2.8 \mathrm{E}-3$ to $1.1 \mathrm{E}-5$. The risk values for the subsurface sediment of the MWOC reach and the subsurface and surface sediment of reach $\mathrm{MMBC}$ are 1.6E-5, 1.1E-5, and 6.4E-5, respectively, which fall in the target risk range of $1 \mathrm{E}-06$ to 1E-04. However, the carcinogenic risk values for all other reaches are greater than $1 \mathrm{E}-04$ and therefore represent high risk to the recreational user. The surface sediments in reach IHP present the greatest human health risk to recreators, with a carcinogenic risk value of $2.8 \mathrm{E}-3$

The industrial carcinogenic risk values for the reaches in WAG 2 vary from $1.9 \mathrm{E}-3$ to $3.2 \mathrm{E}-1$ for the industrial land use scenario. Because these values are greater than $1 \mathrm{E}-04$, they represent high risk for the future industrial worker due to exposure to WAG 2 contaminants. As with the other land use scenarios, the surface sediments in reach IHP present the greatest human health risk to industrial workers, with a carcinogenic risk value of 3.2E-1. Appendix A provides a full summary of the carcinogenic risk results by land use and defined reach. 
Table 25. Summary table of total carcinogenic risk for WAG 2 sediment data

\begin{tabular}{lcccccc}
\hline \multirow{2}{*}{ Reach } & \multicolumn{2}{c}{ Industrial Land Use } & \multicolumn{2}{c}{ Recreational Land Use } & \multicolumn{2}{c}{ Residential Land Use } \\
\cline { 2 - 7 } & Subsurface $^{1}$ & Surface $^{2}$ & Subsurface & Surface & Subsurface & Surface \\
\hline IHP & $4.0 \mathrm{E}-2$ & $6.1 \mathrm{E}-2$ & $1.8 \mathrm{E}-3$ & $2.8 \mathrm{E}-3$ & $2.1 \mathrm{E}-1$ & $3.2 \mathrm{E}-1$ \\
LWOC & $1.3 \mathrm{E}-2$ & $1.2 \mathrm{E}-2$ & $5.8 \mathrm{E}-4$ & $5.4 \mathrm{E}-4$ & $7.2 \mathrm{E}-2$ & $7.2 \mathrm{E}-2$ \\
LMBC & $2.4 \mathrm{E}-3$ & $7.3 \mathrm{E}-3$ & $1.1 \mathrm{E}-4$ & $3.3 \mathrm{E}-4$ & $1.3 \mathrm{E}-2$ & $4.2 \mathrm{E}-2$ \\
MWOC & $3.5 \mathrm{E}-4$ & $5.8 \mathrm{E}-3$ & $1.6 \mathrm{E}-5$ & $2.6 \mathrm{E}-4$ & $1.9 \mathrm{E}-3$ & $3.6 \mathrm{E}-2$ \\
MMBC & $2.9 \mathrm{E}-4$ & $1.5 \mathrm{E}-3$ & $1.1 \mathrm{E}-5$ & $6.4 \mathrm{E}-5$ & $3.1 \mathrm{E}-1$ & $4.1 \mathrm{E}-1$ \\
UMBC & $1.3 \mathrm{E}-2$ & $8.6 \mathrm{E}-3$ & $5.7 \mathrm{E}-4$ & $3.9 \mathrm{E}-4$ & $6.3 \mathrm{E}-2$ & $4.3 \mathrm{E}-2$ \\
\hline
\end{tabular}

Figures 5,6 , and 7 present risk range maps of the industrial scenario for ${ }^{137} \mathrm{Cs},{ }^{60} \mathrm{Co}$, and the total risk of all other contaminants except for ${ }^{137} \mathrm{Cs}$ and ${ }^{60} \mathrm{Co}$ (termed No-Gamma since ${ }^{60} \mathrm{Co}$ and the decay product of ${ }^{137} \mathrm{Cs}$ are gamma emitters). An overlay on the maps show each of the six defined reaches used for calculating the risk and within each box sample by sample risk range estimates are presented. The sample by sample results are size- and color-coded according to the magnitude of the risk. Figure 5 clearly shows the extent of ${ }^{137} \mathrm{Cs}$ contamination in the areas defined along White Oak Creek, while Fig. 6 shows some ${ }^{60} \mathrm{Co}$ contamination along Melton Branch. Figure 7 shows that little contamination is present other than ${ }^{137} \mathrm{Cs}$ and ${ }^{60} \mathrm{Co}$ for the industrial scenario as none of the points register risks above the target risk range after these two analytes are subtracted.

Residential scenario-noncarcinogenic results. The noncarcinogenic human health effects to a future on-WAG resident were determined for exposure to the WAG 2 floodplain soils and sediments via the following exposure pathways: (1) ingestion by a child, (2) ingestion by an adult, (3) ingestion of produce, (4) dermal contact, and (5) inhalation of wind-generated dust particulates. Table 26 provides a summary of the hazard quotients for exposure of a future resident to WAG 2 sediment noncarcinogenic COPCs for surface data $(0$ to $15 \mathrm{~cm}$ below the ground surface). Since cores for metals and organics were not split by depth as they were for radionuclides, all of the analytical data are considered to be representative of the surface layer. In addition, the contaminant, along with the hazard quotient and exposure pathway, which has the greatest contribution to the total hazard index for a reach, is provided in the tables.

Data results provided in Table 26 reveal that mercury, chromium, and manganese detected in the floodplain soils represent the major COCs for noncarcinogenic human health effects to future residents residing on WAG 2. The total hazard indices for both the child and adult in all defined reaches are greater than unity (1.0) and therefore represent a pathway 'of concern. The ingestion of produce pathway is primarily responsible for the hazard indices being high for these reaches. 


\section{Sediment Carcinogenic Risk Ranges for Cs-137: Industrial Scenario}

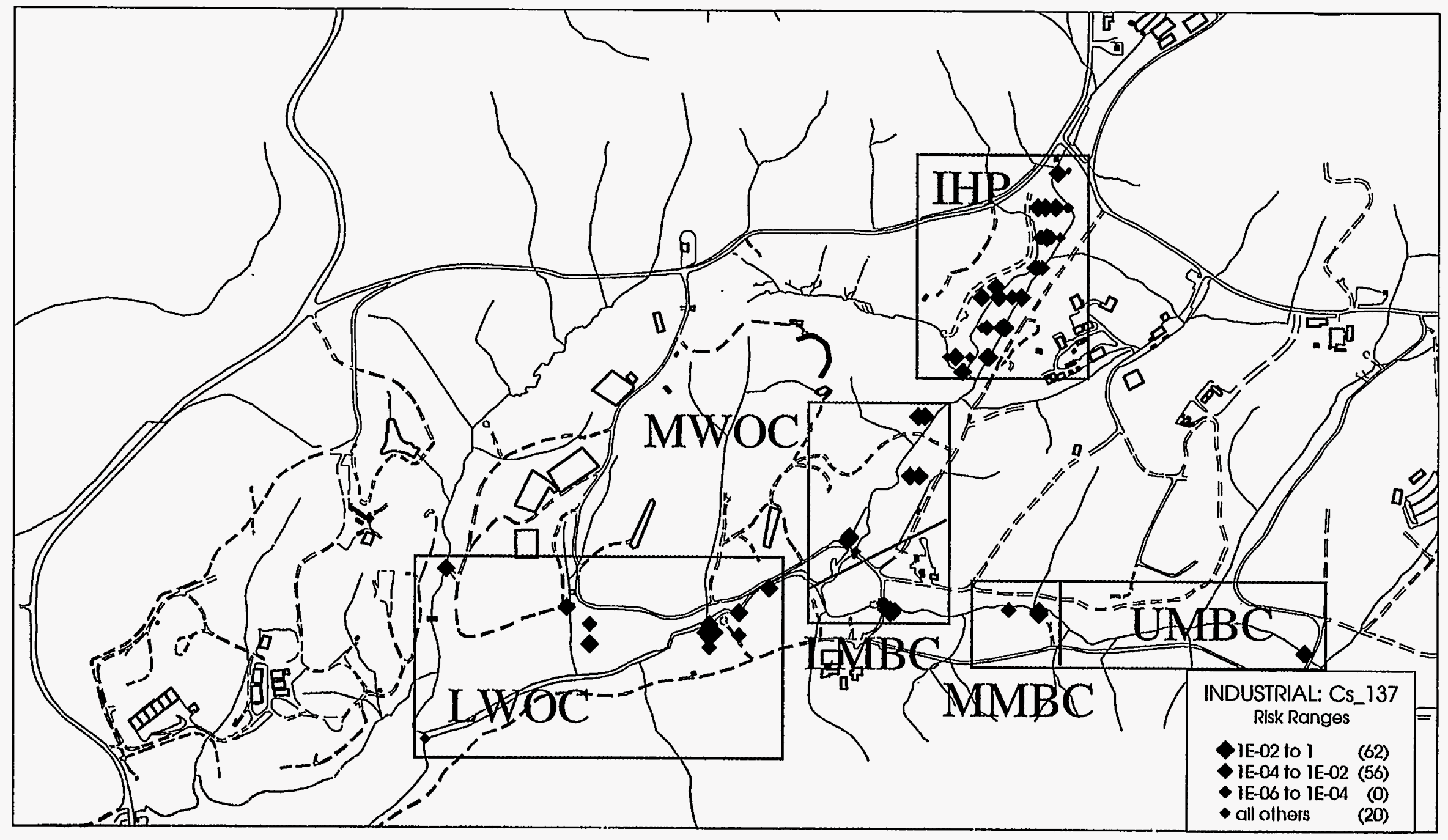

Fig. 5. Floodplain soil and sediment industrial carcinogenic risk ranges for ${ }^{137} \mathrm{Cs}$. 
Sediment Carcinogenic Risk Ranges for Co-60: Industrial Scenario

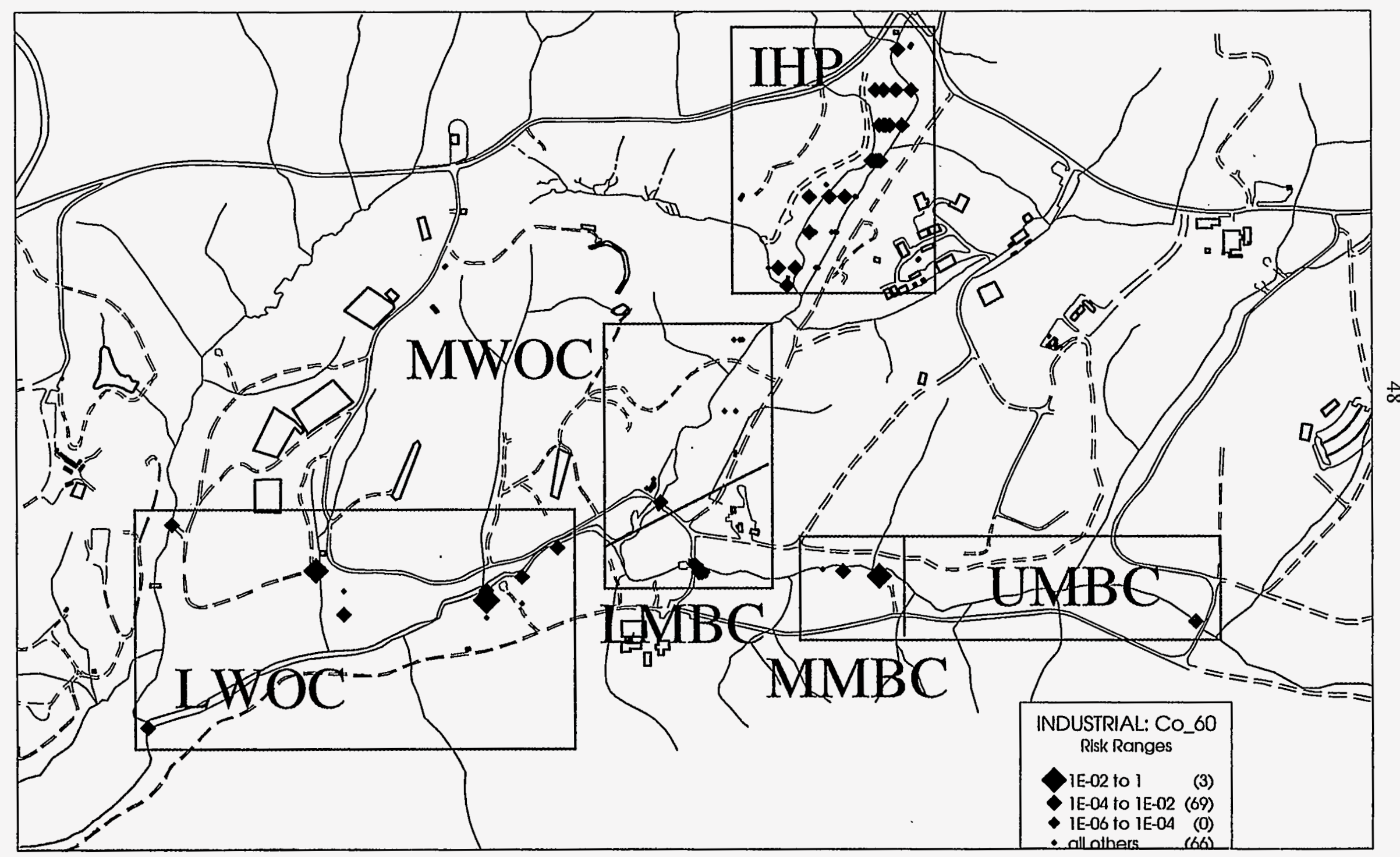

Fig. 6. Floodplain soil and sediment industrial carcinogenic risk Innges for ${ }^{60} \mathrm{Co}$. 


\section{Sediment Carcinogenic Risk Ranges for No Gamma: Industrial Scenario}

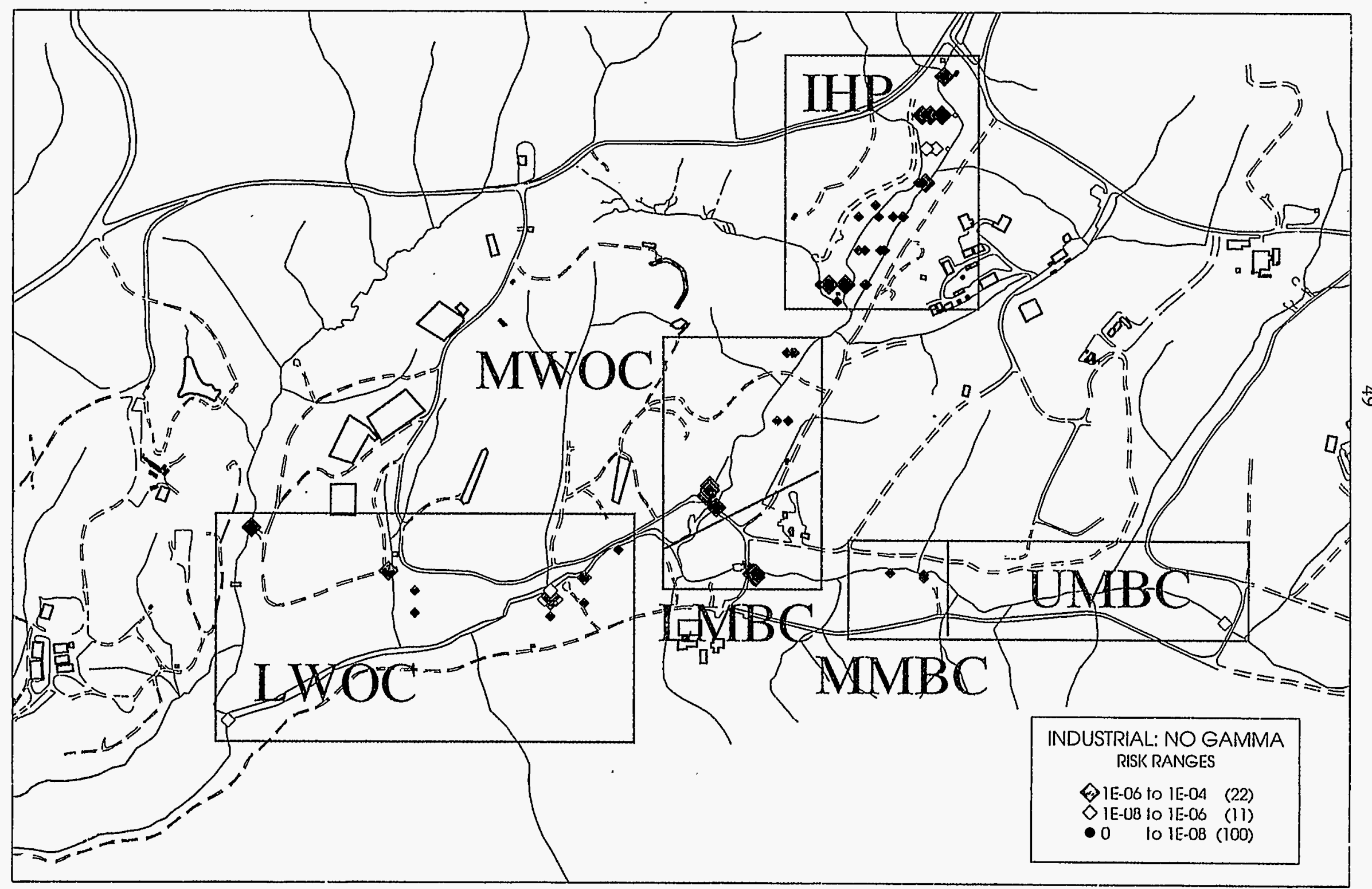

Fig. 7. Floodplain soil and sediment industrial carcinogenic risk ranges for No-Gnmmn. 
Table 26. Summary of hazard quotients for noncarcinogenic effects for WAG 2 sediment data based on residential land use scenario ( 0 to $15 \mathrm{~cm}$ depth samples)

\begin{tabular}{|c|c|c|c|c|c|c|c|c|}
\hline Reach & $\begin{array}{c}\text { Ingestio } \\
\text { n of } \\
\text { sedimen } \\
\text { t-adult }\end{array}$ & $\begin{array}{l}\text { Ingestion } \\
\text { of } \\
\text { sediment- } \\
\text { child }\end{array}$ & $\begin{array}{l}\text { Ingestion } \\
\text { of } \\
\text { produce }\end{array}$ & $\begin{array}{c}\text { Dermal } \\
\text { exposure }\end{array}$ & $\begin{array}{c}\text { Inhalation } \\
\text { of } \\
\text { sediment }\end{array}$ & $\begin{array}{c}\text { Total } \\
\text { hazard } \\
\text { indexं- } \\
\text { adult }\end{array}$ & $\begin{array}{c}\text { Total } \\
\text { hazard } \\
\text { index- } \\
\text { child }\end{array}$ & Summary \\
\hline IHP & 2.5E-1 & $2.3 \mathrm{E}+0$ & $9.0 \mathrm{E}+1$ & $3.9 \mathrm{E}-1$ & $6.0 \mathrm{E}-3$ & $9.1 \mathrm{E}+1$ & $9.3 E+1$ & $\begin{array}{l}\text { Mercury: } \\
7.0 \mathrm{E}+1 \text { for } \\
\text { ingestion of } \\
\text { produce }\end{array}$ \\
\hline LWOC & $3.8 \mathrm{E}-2$ & $3.6 \mathrm{E}-1$ & 1.1E+1 & 7.4E-2 & 2.3E-6 & $1.1 \mathrm{E}+1$ & $1.2 \mathrm{E}+1$ & $\begin{array}{l}\text { Mercury: } \\
6.3 E+0 \text { for } \\
\text { ingestion of } \\
\text { produce }\end{array}$ \\
\hline LMBC & $2.5 \mathrm{E}-2$ & $2.4 \mathrm{E}-1$ & $5.3 \mathrm{E}+0$ & $6.7 \mathrm{E}-2$ & 一 & $5.4 \mathrm{E}+0$ & $5.6 \mathrm{E}+0$ & $\begin{array}{l}\text { Chromium } \\
\text { VI: } 5.3 \mathrm{E}+0 \\
\text { for ingestion } \\
\text { of produce }\end{array}$ \\
\hline MWOC & $.3 .1 \mathrm{E}-2$ & $2.9 \mathrm{E}-1$ & $1.1 \mathrm{E}+1$ & 4.7E-2 & $3.0 \mathrm{E}-6$ & 1.1E+1 & $1.1 \mathrm{E}+1$ & $\begin{array}{l}\text { Mercury: } \\
8.3 \mathrm{E}+0 \text { for } \\
\text { ingestion of } \\
\text { produce }\end{array}$ \\
\hline $\mathrm{MMBC}$ & $1.3 \mathrm{E}-1$ & $1.2 E+0$ & $3.2 E+1$ & $2.4 \mathrm{E}-1$ & $3.7 \mathrm{E}-2$ & $3.2 \mathrm{E}+1$ & $3.3 \mathrm{E}+1$ & $\begin{array}{l}\text { Manganese: } \\
2.1 \mathrm{E}+1 \text { for } \\
\text { ingestion of } \\
\text { produce }\end{array}$ \\
\hline UMBC & $1.5 \mathrm{E}-1$ & $1.4 \mathrm{E}+0$ & $3.5 E+1$ & $2.4 \mathrm{E}-1$ & $3.8 \mathrm{E}-2$ & $3.5 \mathrm{E}+1$ & $3.7 \mathrm{E}+1$ & $\begin{array}{l}\text { Manganese: } \\
2.1 \mathrm{E}+1 \text { for } \\
\text { ingestion of } \\
\text { produce }\end{array}$ \\
\hline
\end{tabular}

The pathway that has the greatest contribution to the hazard indices being greater than 1.0 for all of the reaches is ingestion of produce. In addition, ingestion of sediment by the child receptor produced hazard quotients greater than 1.0 for the IHP, MMBC, and UMBC reaches. Because the hazard quotient for this pathway is greater than 1.0 in these reaches, it is also a pathway of concern for the child receptor in the residential land use scenario.

Mercury is the major COC for the results from the IHP, LWOC, and MWOC reaches (all along White Oak Creek). Chromium VI is the major contaminant responsible for the hazard index being greater than 1.0 for the $L M B C$ reach, whereas manganese is the COC for the data in the MMBC and UMBC reaches. It should be noted that conservatism in the default uptake factors often makes the results from the produce pathway more conservative than the other pathways analyzed.

Recreational scenario-noncarcinogenic results. The noncarcinogenic human health effects to a future on-WAG recreational user were determined for exposure to the WAG 2 floodplain soils and sediments via the following exposure pathways: (1) ingestion by a child, (2) ingestion by an adult, (3) dermal contact, and (4) inhalation of wind-generated dust and particulates. Table 27 provides a summary of the hazard quotients for exposure of a future recreational user to WAG 2 noncarcinogenic COCs. In addition, Table 27 lists the hazard quotients for the exposure pathways and total hazard 
indices for surface sediment data from each reach. The contaminant, along with the hazard quotient and exposure pathway, which has the greatest contribution to the total hazard index for a reach, is also identified in the table.

Table 27. Summary of hazard quotients for noncarcinogenic effects for WAG 2 sediment data based on recreational land use scenario (0 to $15 \mathrm{~cm}$ depth samples)

\begin{tabular}{|c|c|c|c|c|c|c|c|}
\hline Reach & $\begin{array}{l}\text { Ingestion } \\
\text { of } \\
\text { sediment- } \\
\text { adult }\end{array}$ & $\begin{array}{l}\text { Ingestion } \\
\text { of } \\
\text { sediment- } \\
\text { child }\end{array}$ & $\begin{array}{l}\text { Dermal } \\
\text { exposure }\end{array}$ & $\begin{array}{l}\text { Inhalation } \\
\text { of wind- } \\
\text { generated } \\
\text { sediment }\end{array}$ & $\begin{array}{c}\text { Total } \\
\text { hazard } \\
\text { index- } \\
\text { adult }\end{array}$ & $\begin{array}{l}\text { Total } \\
\text { hazard } \\
\text { index- } \\
\text { child }\end{array}$ & Summary \\
\hline IHP & $2.2 \mathrm{E}-3$ & 2.1E-2 & $8.4 \mathrm{E}-2$ & 5.4E-5 & $8.6 \mathrm{E}-2$ & $1.0 \mathrm{E}-1$ & $\begin{array}{l}\text { Aroclor } 1254: \\
4.5 \mathrm{E}-2 \text { for } \\
\text { dermal contact }\end{array}$ \\
\hline LWOC & $3.4 \mathrm{E}-4$ & $3.2 \mathrm{E}-3$ & $1.6 \mathrm{E}-2$ & 2.1E-8 & $1.6 \mathrm{E}-2$ & $1.9 \mathrm{E}-2$ & $\begin{array}{l}\text { Chromium VI: } \\
1.4 \mathrm{E}-2 \text { for } \\
\text { dermal contact }\end{array}$ \\
\hline LMBC & $2.3 \mathrm{E}-4$ & $2.1 E-3$ & $1.4 \mathrm{E}-2$ & - & $1.5 \mathrm{E}-2$ & $1.7 \mathrm{E}-2$ & $\begin{array}{l}\text { Chromium VI: } \\
1.4 \mathrm{E}-2 \text { for } \\
\text { dermal contact }\end{array}$ \\
\hline MWOC & $2.8 \mathrm{E}-4$ & $2.6 \mathrm{E}-3$ & $1.0 \mathrm{E}-2$ & 2.7E-8 & $1.0 \mathrm{E}-2$ & $1.3 \mathrm{E}-2$ & $\begin{array}{l}\text { Chromium VI: } \\
7.0 \mathrm{E}-3 \text { for } \\
\text { dermal contact }\end{array}$ \\
\hline $\mathrm{MMBC}$ & $1.2 \mathrm{E}-3$ & $1.1 \mathrm{E}-2$ & 5.1E-2 & $3.3 E-4$ & $5.2 \mathrm{E}-2$ & $6.2 \mathrm{E}-2$ & $\begin{array}{l}\text { Manganese: } \\
2.3 E-2 \text { for } \\
\text { dermal contact }\end{array}$ \\
\hline UMBC & $1.3 \mathrm{E}-3$ & $1.2 \mathrm{E}-2$ & $5.2 \mathrm{E}-2$ & $3.4 \mathrm{E}-4$ & $5.4 \mathrm{E}-2$ & $6.5 \mathrm{E}-2$ & $\begin{array}{l}\text { Chromium VI: } \\
2.6 \mathrm{E}-2 \text { for } \\
\text { dermal contact }\end{array}$ \\
\hline
\end{tabular}

The hazard quotients and total hazard indices for all of the reaches are less than 1.0. No COCs were identified for this scenario. Therefore, noncarcinogenic human health effects to the future recreational user are of no concern.

Industrial scenario-noncarcinogenic results. The noncarcinogenic human health effects to a future industrial worker were determined for exposure to the WAG 2 floodplain soils and sediments via the following exposure pathways: (1) ingestion, (2) dermal contact, and (3) inhalation of wind-generated dust and particulates. Table 28 provides a summary of the hazard quotients for exposure of a future recreational user to WAG 2 sediment noncarcinogenic COCs. In addition, Table 28 lists the hazard quotients and total hazard indices for data from each reach and the contaminant, along with the hazard quotient and exposure pathway, which has the greatest contribution to the total hazard.

The hazard quotients and total hazard indices for all of the reaches are less than 1.0. No COCs were identified for this scenario. Therefore, noncarcinogenic human health effects to the future industrial user are of no concern. 
Table 28. Summary of hazard quotients for noncarcinogenic effects for WAG 2 sediment data based on industrial land use scenario ( 0 to $15 \mathrm{~cm}$ depth samples)

\begin{tabular}{lccccl}
\hline Reach & $\begin{array}{c}\text { Ingestion of } \\
\text { sediment }\end{array}$ & $\begin{array}{c}\text { Dermal } \\
\text { exposure }\end{array}$ & $\begin{array}{c}\text { Inhalation of } \\
\text { wind- } \\
\text { generated } \\
\text { sediment }\end{array}$ & $\begin{array}{c}\text { Total hazard } \\
\text { index }\end{array}$ & \multicolumn{1}{c}{ Summary } \\
\hline IHP & $8.9 \mathrm{E}-2$ & $1.7 \mathrm{E}-1$ & $4.3 \mathrm{E}-3$ & $2.6 \mathrm{E}-1$ & $\begin{array}{l}\text { Aroclor 1254: } \\
9.0 \mathrm{E}-2 \text { for dermal contact }\end{array}$ \\
LWOC & $1.4 \mathrm{E}-2$ & $3.2 \mathrm{E}-2$ & $1.7 \mathrm{E}-6$ & $4.5 \mathrm{E}-2$ & $\begin{array}{l}\text { Chromium VI: } \\
2.7 \mathrm{E}-2 \text { for dermal contact }\end{array}$ \\
LMBC & $9.1 \mathrm{E}-3$ & $2.9 \mathrm{E}-2$ & - & $3.8 \mathrm{E}-2$ & $\begin{array}{l}\text { Chromium VI: } \\
2.9 \mathrm{E}-2 \text { for dermal contact }\end{array}$ \\
MWOC & $1.1 \mathrm{E}-2$ & $2.0 \mathrm{E}-2$ & $2.2 \mathrm{E}-6$ & $3.1 \mathrm{E}-2$ & $\begin{array}{l}\text { Chromium VI: } \\
1.4 \mathrm{E}-2 \text { for dermal contact }\end{array}$ \\
MMBC & $4.6 \mathrm{E}-2$ & $1.0 \mathrm{E}-1$ & $2.6 \mathrm{E}-2$ & $1.7 \mathrm{E}-1$ & $\begin{array}{l}\text { Manganese: } \\
4.5 \mathrm{E}-2 \text { for dermal contact }\end{array}$ \\
UMBC & $5.2 \mathrm{E}-2$ & $1.0 \mathrm{E}-1$ & $2.7 \mathrm{E}-2$ & $1.8 \mathrm{E}-1$ & $\begin{array}{l}\text { Chromium VI: } \\
5.2 \mathrm{E}-2 \text { for dermal contact }\end{array}$ \\
\hline
\end{tabular}

Table 29 provides a summary of the hazard indices for residential, recreational, and industrial land use scenarios based on the WAG 2 characterization data. Mercury, manganese, and chromium were identified a the primary COCs for the residential land use scenario, and all of the defined reaches exceeded unity for the hazard index. The hazard quotients and total hazard indices for all of the reaches are less than 1.0 for the recreational and industrial scenarios. No COCs were identified for this scenario. Therefore, noncarcinogenic human health effects to the future recreational and industrial user are of no concern. Appendix B provides a full summary of the noncarcinogenic results by land use and by reach.

Table 29. Summary table of hazard indices for noncarcinogenic effects for WAG 2 sediment data

\begin{tabular}{lclc}
\hline Reach & Residential & Recreational & Industrial \\
\hline IHP & $9.1 \mathrm{E}+1$ (adult) & $8.6 \mathrm{E}-2$ (adult) & $2.6 \mathrm{E}-1$ \\
& $9.3 \mathrm{E}+1$ (child) & $1.0 \mathrm{E}-1$ (child) & \\
LWOC & $1.1 \mathrm{E}+1$ (adult) & $1.6 \mathrm{E}-2$ (adult) & $4.5 \mathrm{E}-2$ \\
& $1.2 \mathrm{E}+1$ (child) & $1.9 \mathrm{E}-2$ (child) & \\
LMBC & $5.4 \mathrm{E}+0$ (adult) & $1.5 \mathrm{E}-2$ (adult) & $3.8 \mathrm{E}-2$ \\
& $5.6 \mathrm{E}+0$ (child) & $1.7 \mathrm{E}-2$ (child) & \\
MWOC & $1.1 \mathrm{E}+1$ (adult) & $1.0 \mathrm{E}-2$ (adult) & $3.1 \mathrm{E}-2$ \\
& $1.1 \mathrm{E}+1$ (child) & $1.3 \mathrm{E}-2$ (child) & \\
MMBC & $3.2 \mathrm{E}+1$ (adult) & $5.2 \mathrm{E}-2$ (adult) & $1.7 \mathrm{E}-1$ \\
& $3.3 \mathrm{E}+1$ (child) & $6.2 \mathrm{E}-2$ (child) & \\
UMBC & $3.5 \mathrm{E}+1$ (adult) & $5.4 \mathrm{E}-2$ (adult) & $1.8 \mathrm{E}-1$ \\
& $3.7 \mathrm{E}+1$ (child) & $6.5 \mathrm{E}-2$ (child) & \\
\hline
\end{tabular}




\subsubsection{External exposure calculations with alternative methods}

In addition to the concentration-based risk results presented in the previous sections, risk results based on the Ultrasonic Ranging and Data System walkover data and the HEDOSE model output were generated. Table 30 provides a summary comparison for the three methods for the residential scenario.

Table 30. Comparison of external exposure risk calculations

\begin{tabular}{llllll}
\hline Reach & USRADS & $\begin{array}{l}\text { HEDOSE- } \\
{ }^{60} \mathrm{Co}\end{array}$ & $\begin{array}{l}\text { HEDOSE- } \\
{ }_{137} \mathrm{Cs}\end{array}$ & $\begin{array}{l}\text { Conc. Based } \\
{ }^{60} \mathrm{Co}\end{array}$ & $\begin{array}{l}\text { Conc. Based } \\
{ }^{137} \mathrm{Cs}\end{array}$ \\
\hline IHP & $4.8 \mathrm{E}-1$ & $2.7 \mathrm{E}-6$ & $2.6 \mathrm{E}-3$ & $3.1 \mathrm{E}-3$ & $2.7 \mathrm{E}-1$ \\
MWOC & $1.3 \mathrm{E}-1$ & $5.8 \mathrm{E}-7$ & $1.1 \mathrm{E}-4$ & $1.3 \mathrm{E}-4$ & $2.7 \mathrm{E}-2$ \\
LWOC & $1.8 \mathrm{E}-1$ & $3.5 \mathrm{E}-6$ & $2.2 \mathrm{E}-3$ & $6.9 \mathrm{E}-3$ & $5.2 \mathrm{E}-2$ \\
UMBC & $8.2 \mathrm{E}-3$ & $2.6 \mathrm{E}-5$ & $1.0 \mathrm{E}-7$ & $6.2 \mathrm{E}-2$ & - \\
MMBC & $6.7 \mathrm{E}-3$ & $1.4 \mathrm{E}-4$ & $9.9 \mathrm{E}-7$ & $4.7 \mathrm{E}-3$ & $7.5 \mathrm{E}-4$ \\
LMBC & $3.7 \mathrm{E}-2$ & $2.8 \mathrm{E}-6$ & $3.5 \mathrm{E}-5$ & $4.1 \mathrm{E}-3$ & $3.2 \mathrm{E}-2$ \\
\hline
\end{tabular}

The concentration-based results are those presented earlier for the upper $15 \mathrm{~cm}$ of sediment in each of the reaches. These results are considered the least indicative of the actual risk that would be experienced for the residential scenario. This is due to three primary factors: a bias in the location of the samples, the fact that the calculation of the concentration term does not account for the shielding provided by depth, and the inability of this method to account for shine. The results of all six areas for ${ }^{60} \mathrm{Co}$ and ${ }^{137} \mathrm{Cs}$ exceed the target risk range except for ${ }^{137} \mathrm{Cs}$ in $\mathrm{UMBC}$ (where ${ }^{137} \mathrm{Cs}$ was not detected).

The results given from the HEDOSE code correct one of the problems with the concentration-based method by accounting for the importance of depth. This is accomplished by calculating the effective dose rate by summing a series of plane sources at a number of different depths; this effective dose rate is then converted to a risk result. However, this method still suffers from the bias present in the location of the soil samples, in particular the high proportion of samples collected in the weir pools of LMBC and MWOC. The sampling of IHP, MMBC, and LWOC can be considered more representative of the potential exposures but still lack a random design, and UMBC has only three samples upon which to base an exposure estimate. The results show that IHP, MWOC, and LWOC, basically the entire White Oak Creek main tributary south of WAG 1, exceed the target risk range for ${ }^{137} \mathrm{Cs}$. The middle of the Melton Branch reach, $\mathrm{MMBC}$, exceeds the target risk range for ${ }^{60} \mathrm{Co}$.

The Ultrasonic Ranging and Data System walkover data are the most reliable of the three data sets for calculating the actual exposures at the sites. These data are well representative in terms of the number and location of the samples with more than 300,000 measurements, and they implicitly incorporate the effects of depth and shine. However, there is concern about overcounting due to scattering (DOE 1995b), possibly up to 4 to 5 times the actual dose rate. It is also not possible to individually discriminate the gamma energies due to ${ }^{60} \mathrm{Co}$ and ${ }^{137} \mathrm{Cs}$, so the total risk from gamma is given in the table. The results show that all areas exceed the target risk range with IHP having the highest risk at $4.8 \mathrm{E}-1$. The external exposure pathway is still a problem even if the overcounting factor of 4 to 5 due to scattering is incorporated. 


\subsubsection{Off-site sediment transport risk}

The off-site sediment transport risks presented in this assessment build on those results reported by $D O E$ (1996) by considering possible future distributions of ${ }^{137} \mathrm{Cs}$ and associated levels of risk for the river/lake sediments. The risks are calculated from the simulated sediments distributions resulting from the 100-year flood, as described by Clapp et al. (1996). The assessment addresses the incremental change in risk to human health due to floods. To calculate the incremental risk, the incremental change in ${ }^{137} \mathrm{Cs}$ concentration first is determined by subtracting concentrations for the 100 -year flood from the baseline scenario at selected locations and times. The incremental change in concentration is used directly to generate the incremental risk caused solely by the ${ }^{137} \mathrm{Cs}$ releases due to floods. It is important to note that the actual risks due to exposures to Clinch River sediments would be the sum of the baseline and incremental flood risks if a flood event similar to what is modeled were to occur.

Risk results based on modeled future concentrations of ${ }^{137} \mathrm{Cs}$ were generated for 17 different locations in the Clinch River and 13 locations in Lower Watts Bar. Three different scenarios were used: a baseline case with no flood, a localized flood in the White Oak Creek watershed, and a regional flood that increased flows in the White Oak Creek watershed and in the larger Clinch/Lower Watts Bar watershed. In the output for the off-site transport model, the results were generated at points along the river. The results consisted of sediment thickness and ${ }^{137} \mathrm{Cs}$ concentrations of deposited sediment layers. This detailed distribution of ${ }^{137} \mathrm{Cs}$ allowed the dose to be more accurately determined for the shoreline exposure scenario. The concentration term for the dredging scenario was assumed to be uniformly mixed and was based on the average concentration in the top $30 \mathrm{~cm}$ of the modeled core. Modeled concentrations were available for a 10-year period following the flood event. The modeled concentrations are considered to be representative of both the near-shore sediments and the sediments in the deep water. The increase from the risk calculated for the baseline case with no flood and the risks calculated for the two flood scenarios represents the increased off-site carcinogenic risk from ${ }^{137} \mathrm{Cs}$ contaminated WAG 2 floodplain soil and sediments alone.

The dredging scenario assumed that uniform mixing of the deposited sediments results in a homogeneous concentration of ${ }^{137} \mathrm{Cs}$ in the agricultural soil. Therefore, dose conversion factors for an infinite, uniformly contaminated source was used to determine the dose. For the near-shore scenario, the actual depth distribution of ${ }^{137} \mathrm{Cs}$ was considered for the determination of the external exposure dose based on the shielding properties of the shoreline sediment. The contact pathways and the fish ingestion pathway used the concentrations in the upper layer of the sediment.

The sediment concentrations are developed based on the release of ${ }^{137} \mathrm{Cs}$ associated with a 100 -year flood in the WOC watershed. Three scenarios are calculated: a baseline (no major flood) case, a localized flood in the White Oak Creek watershed, and a regional flood. The floods cause a 3-Ci discharge at White Oak Dam, but off-site conditions lead to substantially different releases from WOC Embayment. For the localized flood, the effect of the Sediment Retention Structure is not considered; therefore, erosion in the embayment mobilizes $2 \mathrm{Ci}$, and the total release is estimated to be $5 \mathrm{Ci}$. In contrast, backwater conditions for the regional flood causes deposition in the embayment and a release of only $2.5 \mathrm{Ci}$. The two flood scenarios yield ${ }^{137} \mathrm{Cs}$ releases that vary by a factor of 2 due largely to off-site conditions during the WOC flood.

A significant portion of the exposure calculated in the following scenarios is a result of historical contamination of the Clinch River by WAG 2 sediment releases. Therefore, the incremental risk from WAG 2 sediments originating after a flood event is calculated for the two flood scenarios by using the difference between the flood event concentrations and the baseline scenario. 
None of the modeled locations indicate risk above the EPA's target risk range of 1E-4 to 1E-6 for the shoreline scenario for the 5-Ci flood or the 2.5-Ci flood.

The risk results for the dredging scenario using both historical and flood generated concentrations were generated for each modeled location. The incremental risks for the local and regional flood events are based on the difference in the concentrations between the flood events and the baseline scenario. The risk results are the 30-year risk from residential/agricultural exposures if the dredged sediments were removed at the time the concentration was modeled.

Figure 8 shows the incremental 30-year risks for six specified locations that show the model behavior over the 10-year period for the local watershed flood for both the local flood (5-Ci release) and the regional flood (2.5-Ci release).

For the local flood, Clinch River Mile 20.7, which is at the confluence of WOC and the Clinch River, shows the risks approaching $1 \mathrm{E}-3$ in the period immediately following the flooding. The risk values for 6 months are the highest calculated incremental risk for any of the areas and flood events examined for this report. The calculated risk reaches the maximum value immediately after the 100-year flood that "occurred" in March, and the risk stays elevated through the summer until seasonal winter floods sweep the contaminated sediments downstream. The risk results for the 5-Ci release for river reach between CRM 20.7 and CRM 11.8 tends to go below the $1 \mathrm{E}-6$ level at some point, indicating that the sediments in that region get scoured sometime during the 10 years. For CRM 4.2 to CRM 0, the water elevation is maintained year-round by Watts Bar Dam. Because the water is deeper, sediments tend to persist (i.e., they are not scoured); nevertheless, the risk levels are all below the target level. CRM0.0 is the last measured location before the Clinch River flows into the Tennessee River.

\subsubsection{Surface Water}

The data collected from the WAG 2 surface water are divided into the following two categories (with separate carcinogenic and noncarcinogenic risk values calculated for each): tributaries and seeps. A future residential land use scenario was the only scenario evaluated for the tributaries data. However, in addition to a future residential land use scenario, a future recreational user was considered as a potential receptor to contamination in the WAG 2 seeps.

\subsubsection{Tributaries}

The tables in Appendix $\mathrm{C}$ give the total carcinogenic risk by sample based on exposure to ${ }^{137} \mathrm{Cs}$, ${ }^{60} \mathrm{Co}$, ${ }^{90} \mathrm{Sr}$, and tritium. Appendix D provides the total noncarcinogenic hazard index by sample based on exposure to barium, boron, manganese, mercury, strontium, and zinc. The hazard index values represent the sum of the hazard quotients for the ingestion, inhalation, and dermal contact with surface water pathways.

Data locations analyzed and discussed here include the East Seep monitoring station at WAG 7 (ESP), the Homogeneous Reactor Test tributary site draining WAG 9 (HRT), Monitoring Station 1 (MS1) and T2A on the WAG 4 tributary, and a ${ }^{60} \mathrm{Co}$ seep from Trench 7 in WAG 7 (S75). For the ESP data set, the contaminants that have a total risk value greater than $1.0 \mathrm{E}-04$, due to residential exposure to surface water include ${ }^{60} \mathrm{Co},{ }^{90} \mathrm{Sr}$, and tritium. However, few samples exceeded $1.0 \mathrm{E}-4$ for these contaminants. For ${ }^{60} \mathrm{Co}$, two samples exceed a risk value of $1.0 \mathrm{E}-04$, while only one sample exceeded the target risk range for tritium, and five samples exceeded the range for ${ }^{90} \mathrm{Sr}$. The application of the residential scenario based on the representative exposure concentration (the upper 


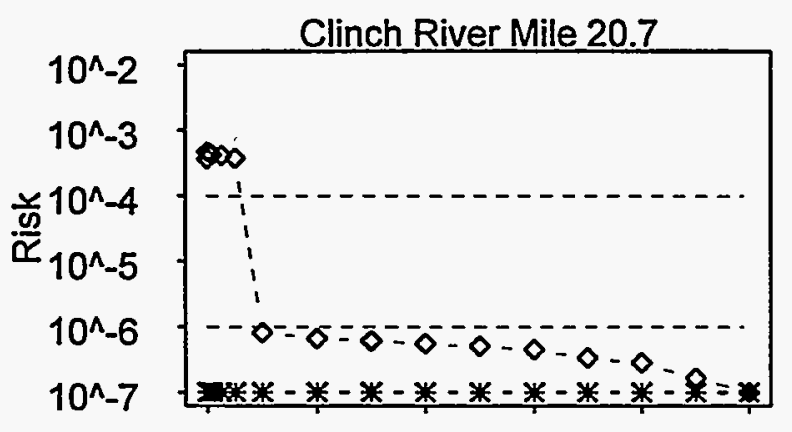

$\begin{array}{llllll}0 & 2 & 4 & 6 & 8 & 10\end{array}$

Years

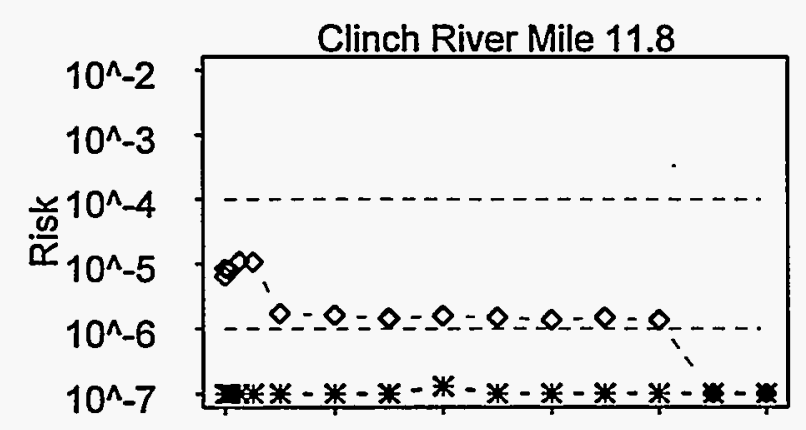

$\begin{array}{llllll}0 & 2 & 4 & 6 & 8 & 10\end{array}$

Years

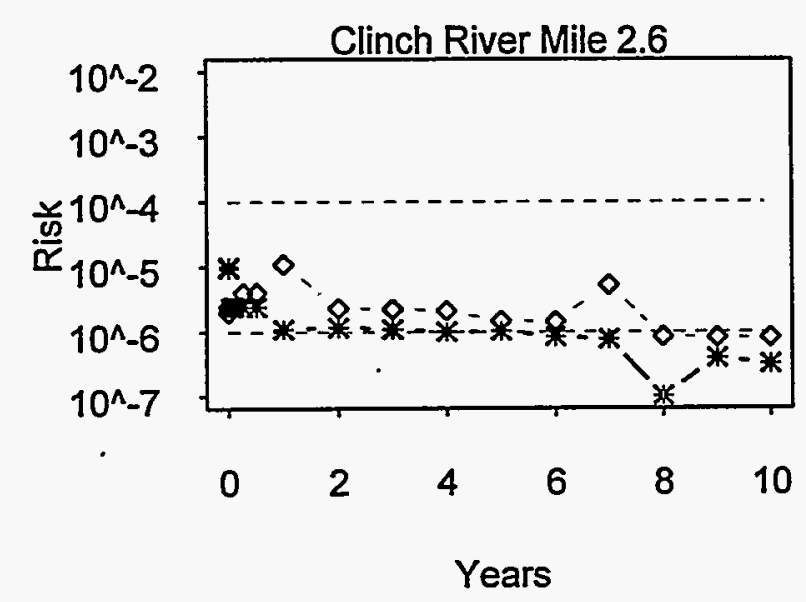

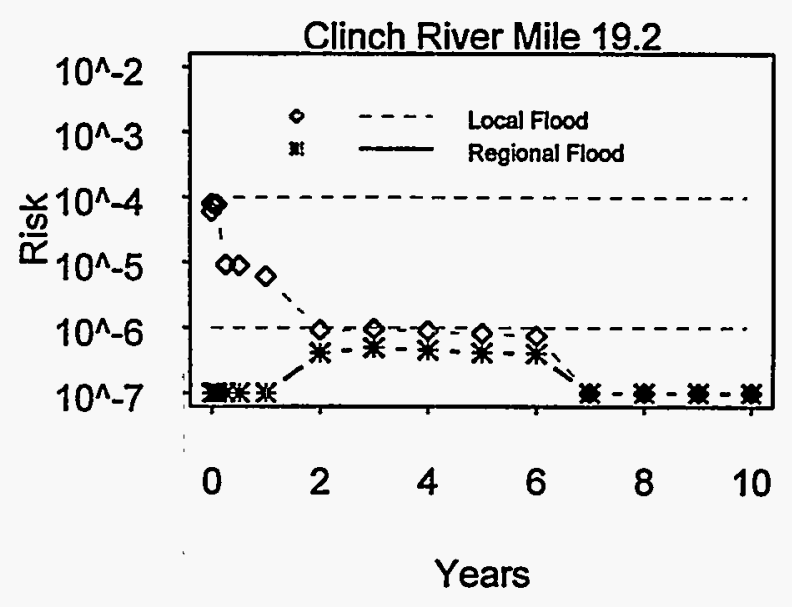
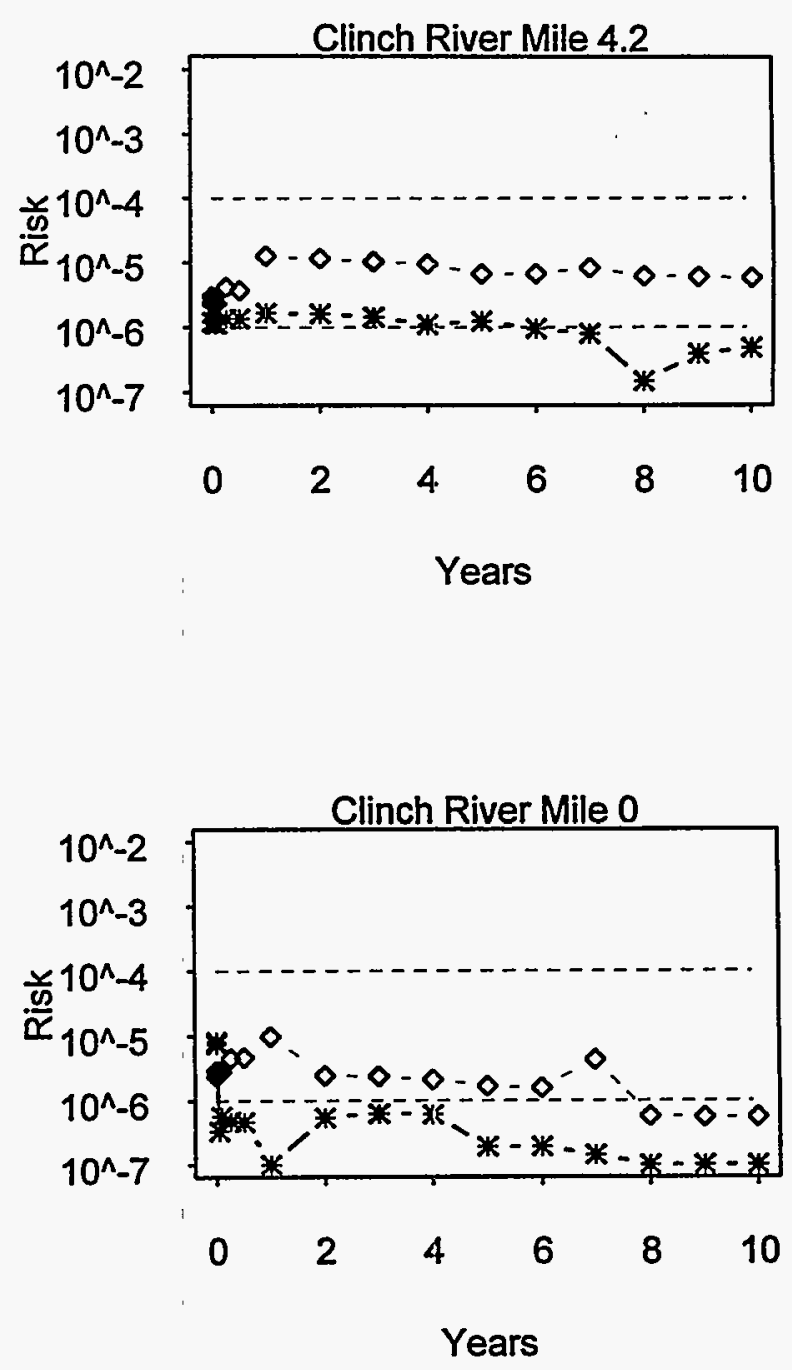

Fig. 8. Incremental cancer risk from dredging scenario-Clinch River 
95th confidence limit on the mean for all the samples) for ESP does not exceed the target risk range for these carcinogenic contaminants.

For the HRT data set, ${ }^{90} \mathrm{Sr}$ is the only $\mathrm{COC}$ which represents high risk, with risk values exceeding 1.0E-04. However, ${ }^{90} \mathrm{Sr}$ exceeding a total risk of $1.0 \mathrm{E}-4$ occurs in every sample of the HRT data set. For the MS1 data set, ${ }^{90} \mathrm{Sr}$ and tritium are the $\mathrm{COCs}$ with risk values exceeding $1.0 \mathrm{E}-04$. This also occurs for every sample reported for the MS1 data. ${ }^{60} \mathrm{Co}$ is the only $\mathrm{COC}$ with risk values exceeding $1 \mathrm{E}-4$ for the S75 data set, with five samples exceeding 1.0E-4. For the T2A data set, ${ }^{90} \mathrm{Sr}$ and tritium are the high priority $\mathrm{COCs}$ with risk values exceeding $1.0 \mathrm{E}-4$. Risk values for ${ }^{90} \mathrm{Sr}$ and tritium exceed $1.0 \mathrm{E}-4$ for every sample reported in the T2A data. As expected, the ${ }^{60} \mathrm{Co}$ seep (S75) showed risks from ${ }^{60} \mathrm{Co}$ greater than the target risk range. Four of the six results analyzed were greater than $1.0 \mathrm{E}-4 .{ }^{137} \mathrm{Cs}$ did not exceed the target risk range at any time or location.

The noncarcinogenic human health effects to a future on-WAG resident were determined for exposure to the surface water via the following exposure pathways: (1) ingestion, (2) dermal contact, and (3) inhalation of volatiles. However, no contaminants exceed a total hazard index value of 1.0 for any of the samples for the tributary assessment task. Therefore, noncarcinogenic human health effects due to exposure to contaminants in the surface water are not a concern for the metals analyzed (boron, mercury, zinc, barium, strontium, and manganese) at these sites.

\subsubsection{Seep task data}

Calculations were performed at all sampling locations for the recreational and residential water use scenarios. The carcinogenic risks and noncarcinogenic health effects were determined for exposure to contaminated surface water based on the accumulated surface water data set via the following exposure pathways for future residents: (1) ingestion, (2) dermal contact, and (3) inhalation of volatiles and radionuclides during household use. The exposure pathways evaluated for future on-WAG recreational users include: (1) incidental ingestion of surface water, (2) dermal contact with surface water, and (3) ingestion of contaminated fish. The carcinogenic and noncarcinogenic risk results for the entire WAG 2 seeps data set are provided by sampling location in Appendixes $E$ and F of this report for the recreational and residential scenarios. Appendix G demonstrates the impact of the inclusion and exclusion of the ${ }^{90} \mathrm{Sr}$ data that were identified as having chain-of-custody problems in Hicks (1996). Overall, exclusion of this data has little impact on the overall pattern of observed ${ }^{90} \mathrm{Sr}$ contamination and total risk.

Due to the large number of sites analyzed (more than170), the full results for the recreational and residential land use scenarios can be found in the appendixes. Maps of the surface water risk ranges are used to present the results. The most prevalent risk-driving contaminants in surface water are ${ }^{90} \mathrm{Sr}$ and ${ }^{3} \mathrm{H}$, so maps for these contaminants alone are presented along with the total risk figures. Carcinogenic risk results are presented in Figs. 9 to 12. Figure 9 shows the total results for the White

Oak Creek watershed with almost all results exceeding the target risk range and about $20 \%$ of the results exceeding a residential risk of $1.0 \mathrm{E}-2$. Figure 10 shows the ${ }^{90} \mathrm{Sr}$ results for the same locations. One hundred twenty of the 169 areas analyzed for ${ }^{90} \mathrm{Sr}$ exceed the target risk range, and about $10 \%$ of the sites exceed a risk of $1 \mathrm{E}-2$. Risk results exceeding $1.0 \mathrm{E}-2$ for ${ }^{90} \mathrm{Sr}$ are concentrated along Melton Branch and the tributary draining WAG 4. Results for tritium (Fig. 11) are similar, with more than half of the areas exceeding the target risk range and about $20 \%$ exceeding a risk of $1.0 \mathrm{E}-2$. In addition to Melton Branch and the tributary draining WAG 4, some areas in WAG 6 exceed a risk of 1.0E-2. 


\section{Surface Water Total Carcinogenic Risk Ranges: Residential Scenario}

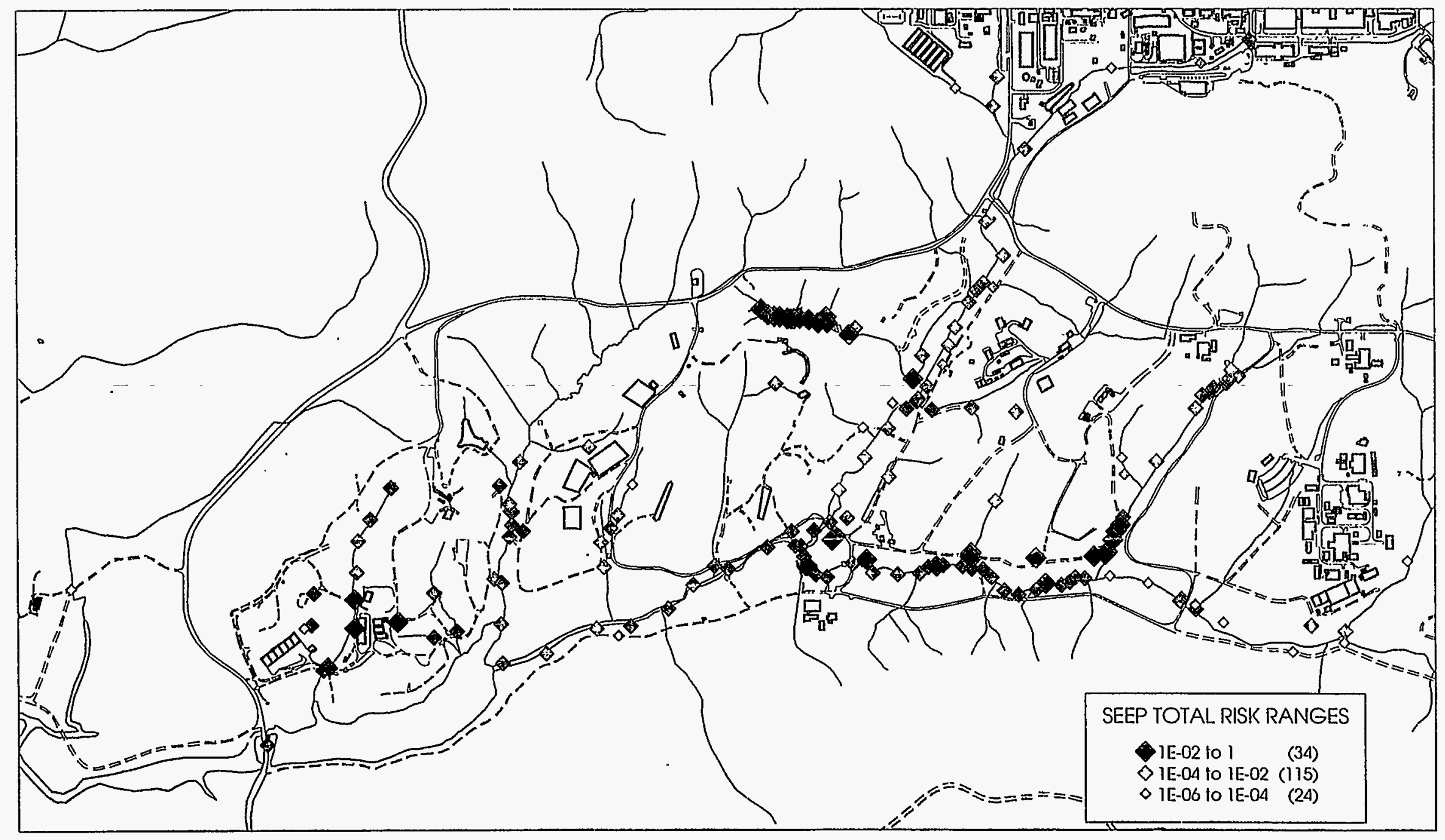




\section{Surface Water Carcinogenic Risk Ranges for Sr-90: Residential Scenario}

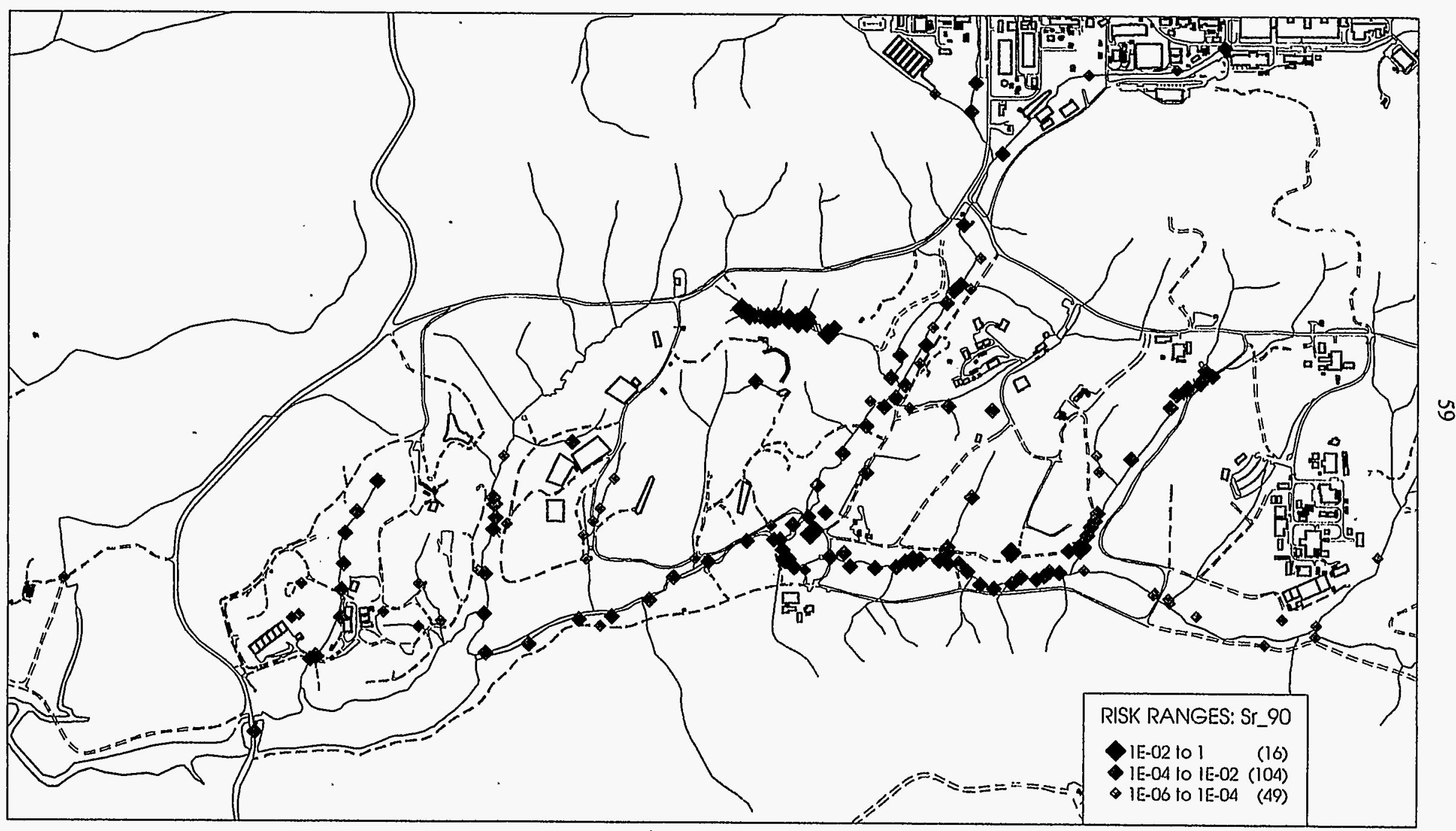

Fig. 10. Surface water carcinogenic risk ranges for ${ }^{90}$ Sr: residential scenario. 


\section{Surface Water Carcinogenic Risk Ranges for Tritium: Residential Scenario}

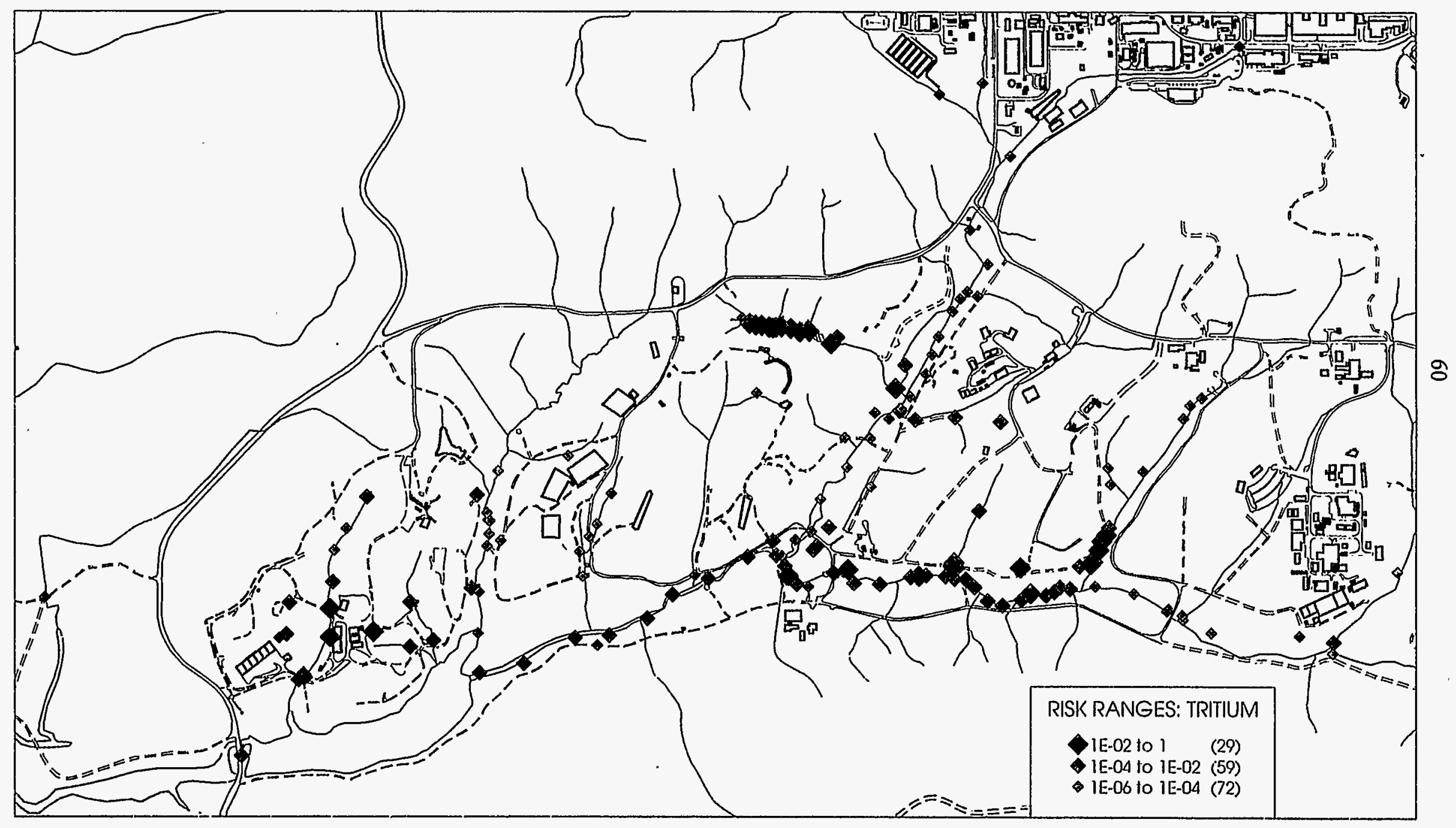

Fig. 11. Surface water carcinogenic risk ranges for tritium: residential scenario. 


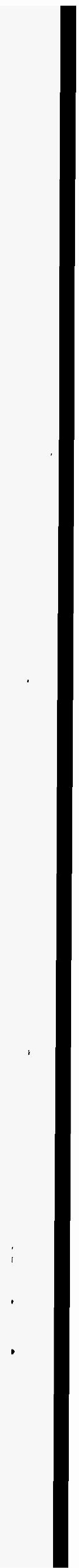




\section{Surface Water Total Carcinogenic Risk Ranges: Recreational (No Fish) Scenario}

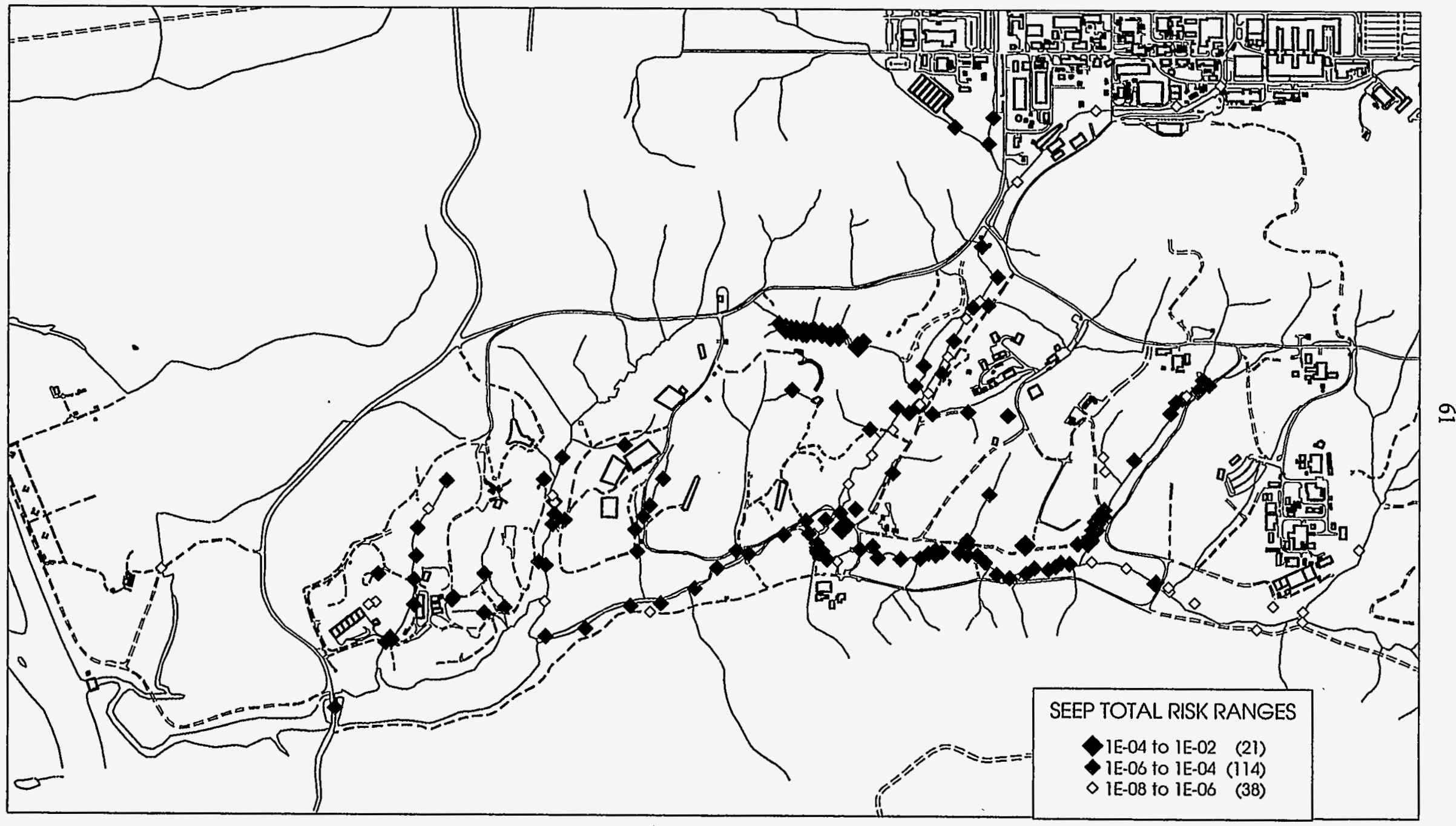

Fig. 12. Surface water total carcinogenic risk ranges: recreational (no fish) scenario. 
The recreational results (without the fish ingestion pathway) are presented in Fig. 12. These results show significantly less risk than the residential pathway with about $15 \%$ of the results exceeding the target risk range and no results above 1.0E-2.

Noncarcinogenic risk results are presented in Figs. 13 and 14. Figure 13 shows that more than half of the risk results exceed unity for the residential scenario, and Fig. 14 shows that no concern is warranted for any of the sites sampled for noncarcinogenic contaminants under the recreational scenario (without the fish ingestion pathway).

\subsection{SUMMARY}

For the analysis of the residential land use scenario for floodplain soil and sediment, the carcinogenic risk at all of the reaches is above the target risk range since all risk values are greater than 1.0E-04. The risk values for subsurface and surface data for the residential land use scenario are within an order of magnitude of each other. Floodplain soils and sediment at all reaches present high human health risks to receptors under the residential scenario (risk $\geq 1.0 \mathrm{E}-4$ ), the surface sediments in reach IHP present the greatest human health risk for future residents, with a risk value of 7.8E-1. The primary contaminants for exposure to WAG 2 floodplain soils and sediment are ${ }^{60} \mathrm{Co}$ and ${ }^{137} \mathrm{Cs}$, via the external exposure to radionuclides pathway.

The recreational risk values for all of the reaches vary from 2.8E-3 to 1.1E-5. The risk values for the subsurface sediment of reach MWOC (the lower portion of White Oak Creek above the confluence of White Oak Creek and Melton Branch) and the subsurface and surface sediment of reach MMBC (Melton Branch in the vicinity of WAG 5) are 1.6E-5, 1.1E-5, and 6.4E-5, respectively, which fall in the target risk range of 1E-06 to 1E-04. However, the carcinogenic risk values for all other reaches are greater than 1E-04 and therefore represent high risk to the recreational user. The surface sediments in reach IFP (which includes the intermediate holding pond area) present the greatest human health risk to recreators, with a carcinogenic risk value of $2.8 \mathrm{E}-3$.

The industrial carcinogenic risk values for the reaches in WAG 2 vary from $1.9 \mathrm{E}-3$ to $3.2 \mathrm{E}-1$ for the industrial land use scenario. Because these values are greater than $1 \mathrm{E}-04$, they represent high risk for the future industrial worker due to exposure to WAG 2 contaminants. As with the other land use scenarios, the surface sediments in reach IHP (the intermediate holding pond area) present the greatest human health risk to industrial workers, with a carcinogenic risk value of 3.2E-1.

Mercury, manganese, and chromium were identified a the primary contaminants of concern (COCs) for the residential land use scenario, and all of the defined reaches exceeded unity for the hazard index. The hazard quotients and total hazard indices for all of the reaches are less than 1.0 for the recreational and industrial scenarios. No COCs were identified for this scenario. Therefore, noncarcinogenic human health effects to the future recreational and industrial user are of no concern.

Surface water sampling locations from the 1992 seep task, the 1993-1994 seep task, the tributary assessment task, and the WAG $5 \mathrm{RI}$ are used to assess risk for the recreational and residential scenarios at each measured surface water location in the watershed.

Due to the large number of sites analyzed (more than 170), the full results for the recreational and residential land use scenarios for surface water are presented with risk range maps in the risk characterization section. The most prevalent risk-driving contaminants in surface water are ${ }^{90} \mathrm{Sr}$ and ${ }^{3} \mathrm{H}$. Almost all of the total residential risk results exceed the target risk range and about $20 \%$ of the 
63

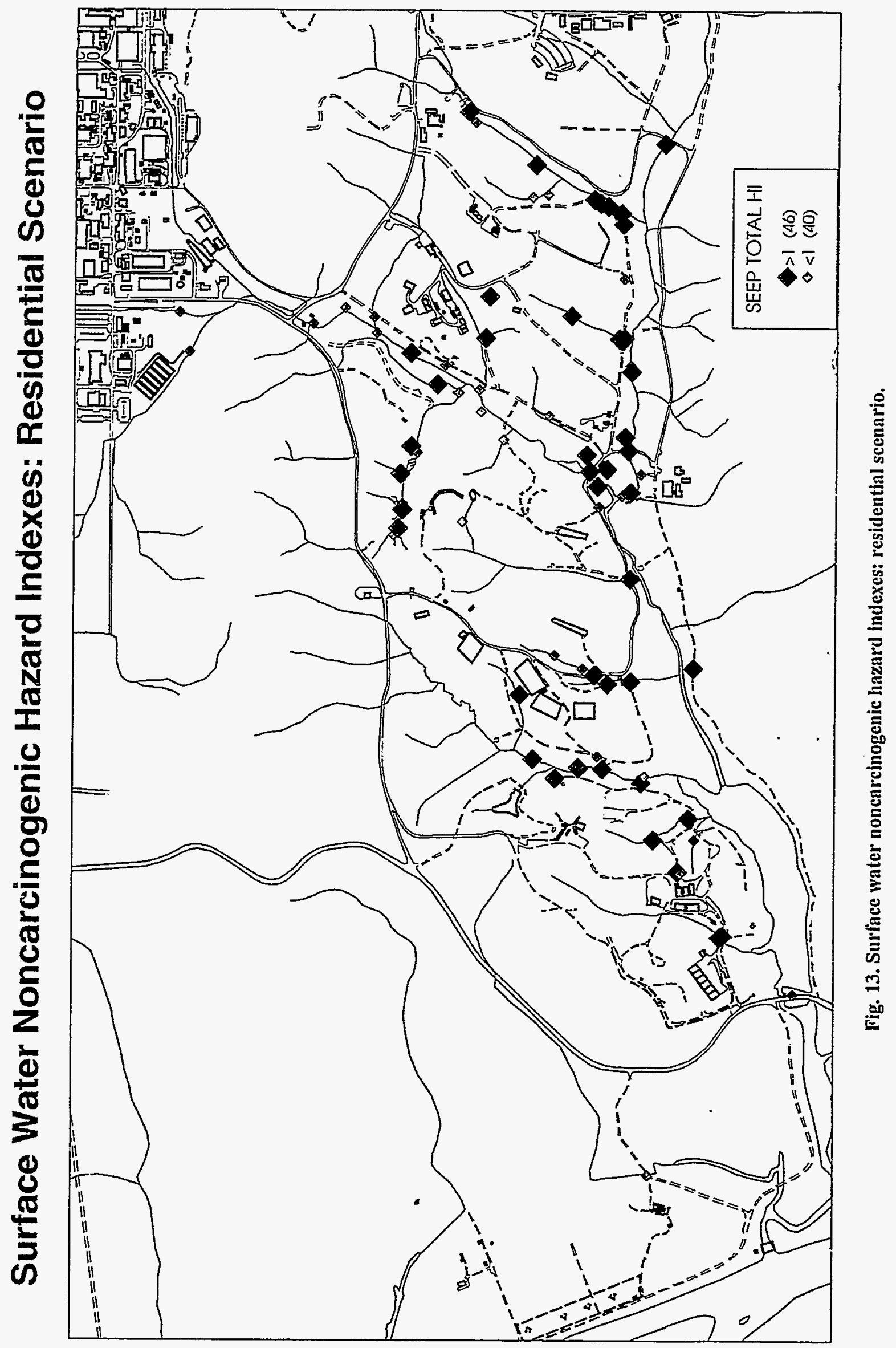




\section{Surface Water Noncarcinogenic Hazard Indexes: Recreational (No Fish) Scenario}

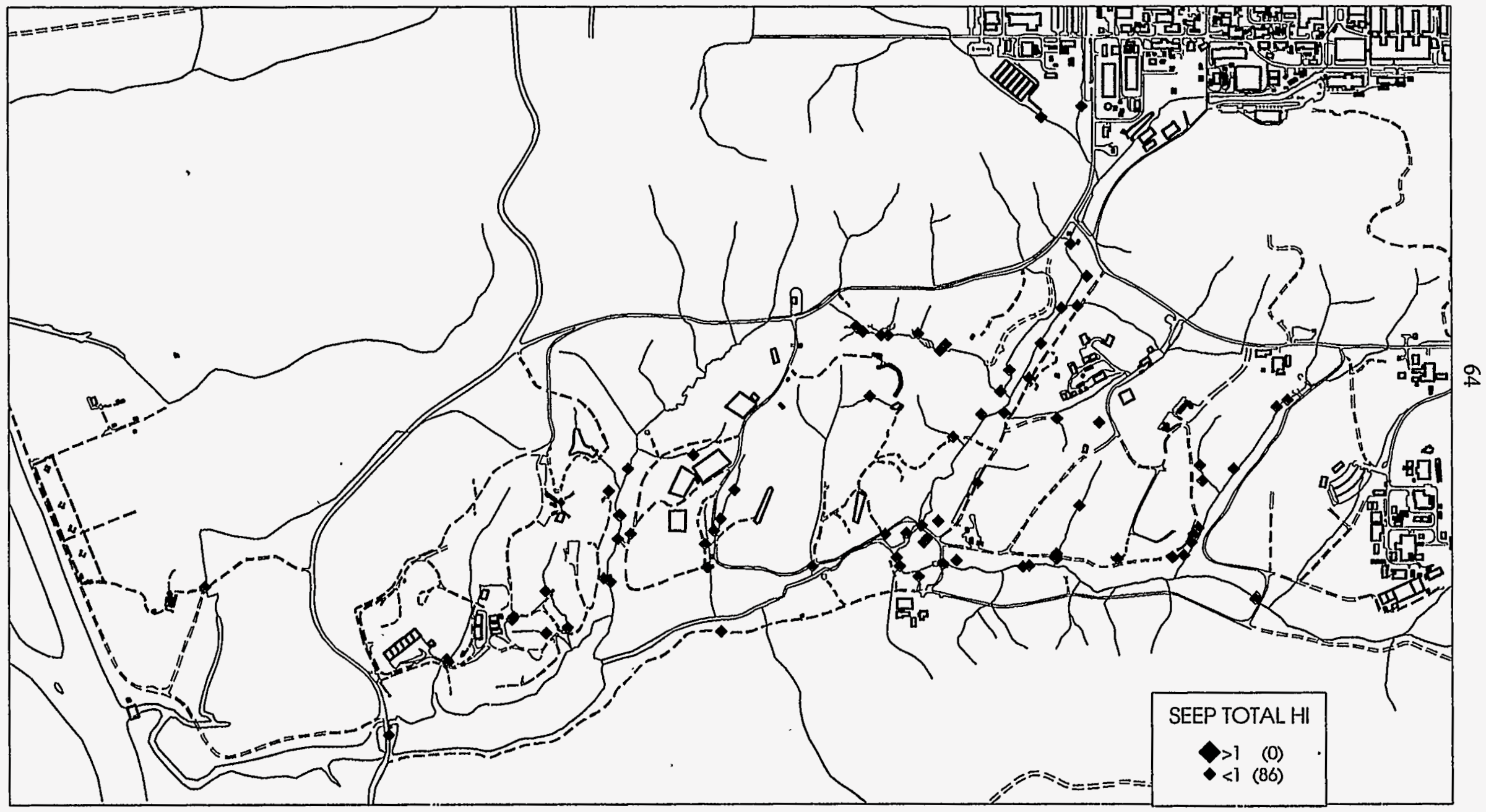

Fig. 14. Surface water noncarcinogenic hazard indexes: recrentional (no fish) scenario. 
results exceed a residential risk of $1.0 \mathrm{E}-2$. A total of 120 of the 169 areas analyzed for ${ }^{90} \mathrm{Sr}$ exceed the target risk range, and about $10 \%$ of the sites exceed a risk of $1.0 \mathrm{E}-2$. Risk results exceeding $1.0 \mathrm{E}-2$ for ${ }^{90} \mathrm{Sr}$ are concentrated along Melton Branch and the tributary draining WAG 4. Results for tritium are similar, with more than half of the areas exceeding the target risk range and about $20 \%$ exceeding a risk of 1E-2. In addition to Melton Branch and the tributary draining WAG 4, some areas in WAG 6 exceed a risk of $1 \mathrm{E}-2$. The recreational results (without the fish ingestion pathway) show significantly less risk than the residential pathway with about $15 \%$ of the results exceeding the target risk range and no results above $1.0 \mathrm{E}-2$.

Noncarcinogenic risk results show more than half of the risk results exceeding unity for the residential scenario and that no concern is warranted for any of the sites sampled for noncarcinogenic contaminants under the recreational scenario (without the fish ingestion pathway).

\section{REFERENCES}

Bechtel National Inc. 1995. Remedial Investigation of Waste Area Grouping 5 at Oak Ridge National Laboratory Oak Ridge, Tennessee. DOE/OR/01-1326\&D1.

BEIAS (Biomedical and Environmental Information Analysis Section). 1995. Toxicity Values for Use in Hazardous Waste Risk Assessment and Remediation. ES/ER/TM-76/R1, Health Sciences Research Division, Oak Ridge National Laboratory, Oak Ridge, Tennessee.

Borders, D. M., D. J. Pridmore, J. J. Beauchamp, D. E. McConnell, S. T. Purucker, and T. M. Scanlon. 1996. Waste Area Grouping Phase I Remedial Investigation Report: Tributary Data Assessment. ORNL/ER-362.

Cember, H. 1989. Introduction to Health Physics. Oxford: Pergamon Press.

Clapp, R. B., Y. S. Bao, T. D. Moore, A. L. Brenkert, S. T. Purucker, D. K. Reece, and B. B. Burgoa. 1996. Waste Area Grouping 2, Phase I Remedial Investigation: Sediment and Cesium-137 Transport Modeling Report. Oak Ridge National Laboratory, Oak Ridge, Tennessee.

DOE (Department of Energy). 1994a. FY 1995 Remedial Investigation Work Plan for Waste Area Grouping 2 at the Oak Ridge National Laboratory, Oak Ridge, Tennessee. DOE/ORNL/011292\&D1, Oak Ridge National Laboratory, Oak Ridge, Tennessee.

DOE. 1994b. Third Annual Environmental Restoration Monitoring and Assessment Report for FY 1994 of Oak Ridge National Laboratory, Oak Ridge, Tennessee. DOE/OR-1070\&D1, Oak Ridge National Laboratory, Oak Ridge, Tennessee.

DOE. 1995. Remedial Investigation/Feasibility Study for the Clinch River/Poplar Creek Operable Unit. DOE/OR/01-1393V1\&D1.

DOE. 1995a. Phase I Remedial Investigation Report of Waste Area Grouping 2 at Oak Ridge National Laboratory, Oak Ridge, Tennessee. DOE/OR/01-1413\&D1. Oak Ridge National Laboratory, Oak Ridge, Tennessee. 
DOE. 1995b. Fourth Annual Environmental Restoration Monitoring and Assessment Report (FY 1995), Oak Ridge, Tennessee. DOE/OR/01-1413\&D1, Oak Ridge National Laboratory, Oak Ridge, Tennessee.

Eckermann, K. F. and J. C. Ryman. 1993. External Exposure to Radionuclides in Air, Water, and Soil. Federal Guidance Report No. 12. Office of Radiation and Indoor Air. U.S. Environmental Protection Agency. Washington, D.C.

EPA (Environmental Protection Agency). 1989. Risk Assessment Guidance for Superfund: Volume I- Human Health Evaluation Manual (Part A), EPA/540/1-89/002, Office of Emergency and Remedial Response, Washington, D.C.

EPA (Environmental Protection Agency). 1991a. Risk Assessment Guidance for Superfund. Volume 1, Human Health Evaluation Manual (Part B, Development of Risk-based Preliminary Remediation Goals), OSWER Directive 9285.7-01B, Office of Emergency and Remedial Response, Washington, D.C.

EPA. 1991b. Standard Default Factors, OSWER Directive 9285.6-03, Office of Emergency and Remedial Response, Washington, D.C.

EPA. 1991c. Appendix D of RAGS, Vol. 1, Human Health ("Correction to RAGS-Part B, Sections 3.3.1 and 3.3.2").

EPA. 1994. Guidance for the Data Quality Objectives Process. EPA QA/G-4, Office of Emergency and Remedial Response.

EPA. 1993. Guidance on Conducting Non-Time Critical Removal Actions Under CERCLA. EPA/540-R-93-057, Office of Emergency and Remedial Response, Washington, D.C.

Ford, C. J., J. E. Nyquist, S. T. Purucker, and R. F. Winterfield. 1996. Characterization and Inventory of Contaminants in WAG 2 Floodplain Soils of White Oak Creek. ORNL/TM-13208.

Hicks, D. S. 1996. Waste Area Grouping 2, Remedial Investigation Phase I Seep Task Data Report: Contaminant Source Area Assessment. ORNL/ER-363. Oak Ridge National Laboratory, Oak Ridge, Tennessee.

ICRP (International Commission on Radiological Protection) 1991. 1990 Recommendations of the International Commission on Radiological Protection. Oxford: Pergamon Press; Annals of the ICRP 15(3).

Jacob, P., H. G. Paretzke, H. Rosenbaum, and M. Zankl. 1986. Effective Dose Equivalents for Photon Exposures from Plane Sources on the Ground. Radiation Protection and Dosimetry. 14, 299.

LMES (Lockheed Martin Energy Systems, Inc.). 1996a. Preliminary Remediation Goals for Use at the U.S. Department of Energy Oak Ridge Operations Office. ES/ER/TM-106, Risk Analysis Section, Health Sciences Research Division, Oak Ridge National Laboratory, Oak Ridge, Tennessee.

LMES (Lockheed Martin Energy Systems). 1996b. Role of Risk Assessment at DOE-ORO. $\mathrm{ES} / \mathrm{ER} / \mathrm{TM}-180$. 
ORNL (Oak Ridge National Laboratory). 1990. Remedial Investigation Plan for Waste Area Grouping 2. ORNL/ER-14\&D1, Oak Ridge National Laboratory, Oak Ridge, Tennessee. 


\begin{abstract}
APPENDIX A
CARCINOGENIC RISK TABLES FOR THE SEDIMENT IN FLOODPLAIN SOIL DATA USED IN THE WAG 2 ASSESSMENT
\end{abstract}


$\mid$ 


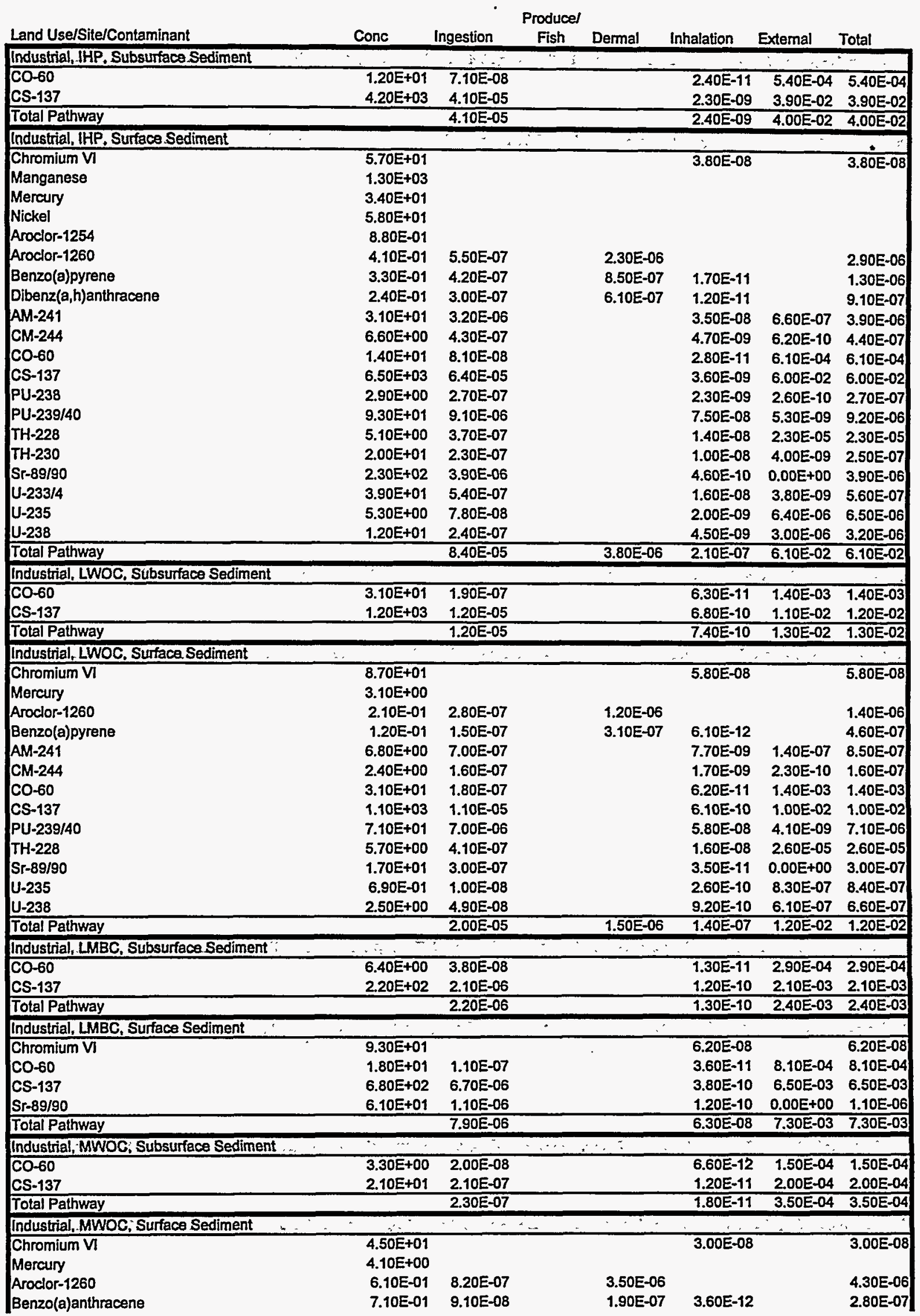




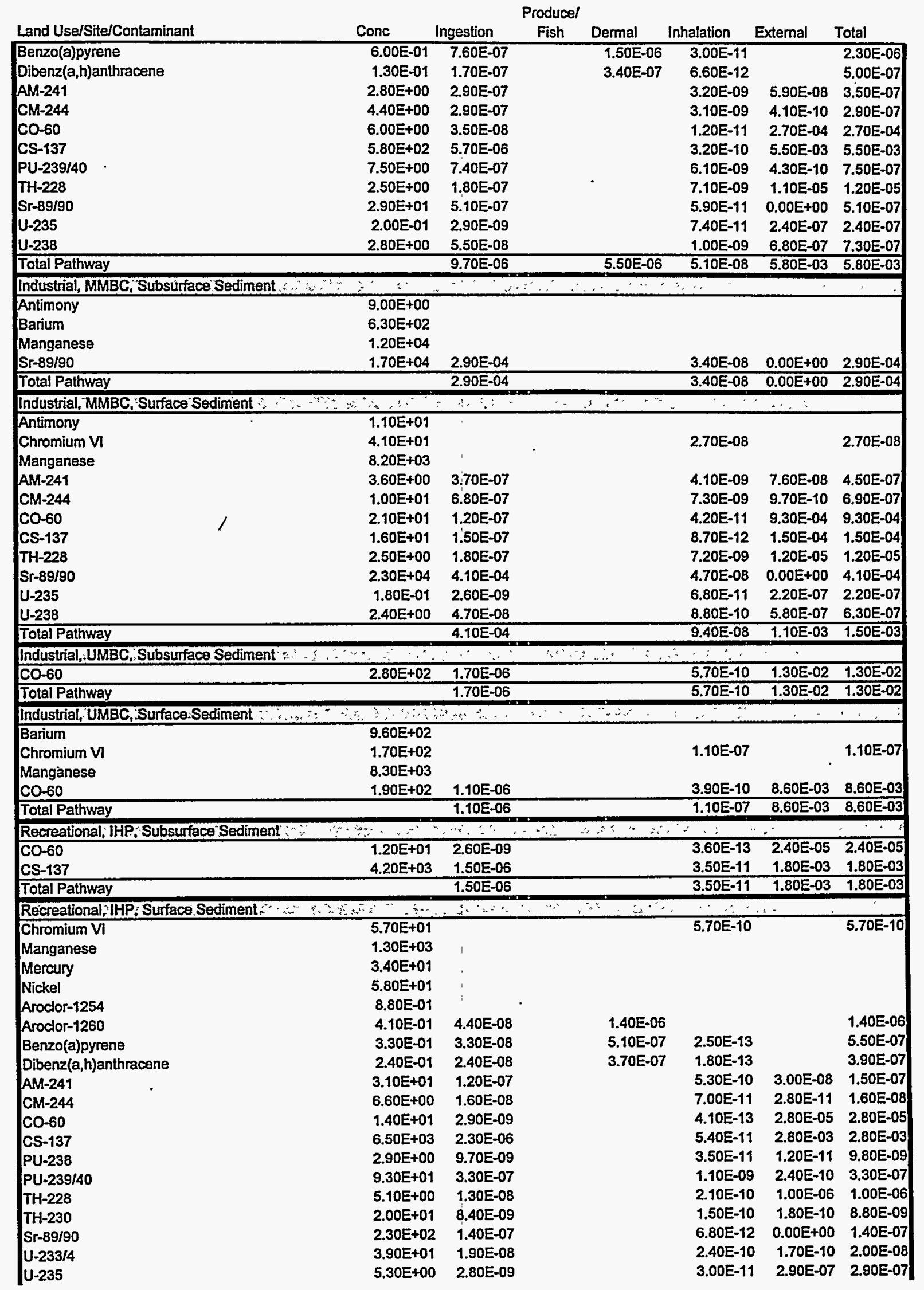




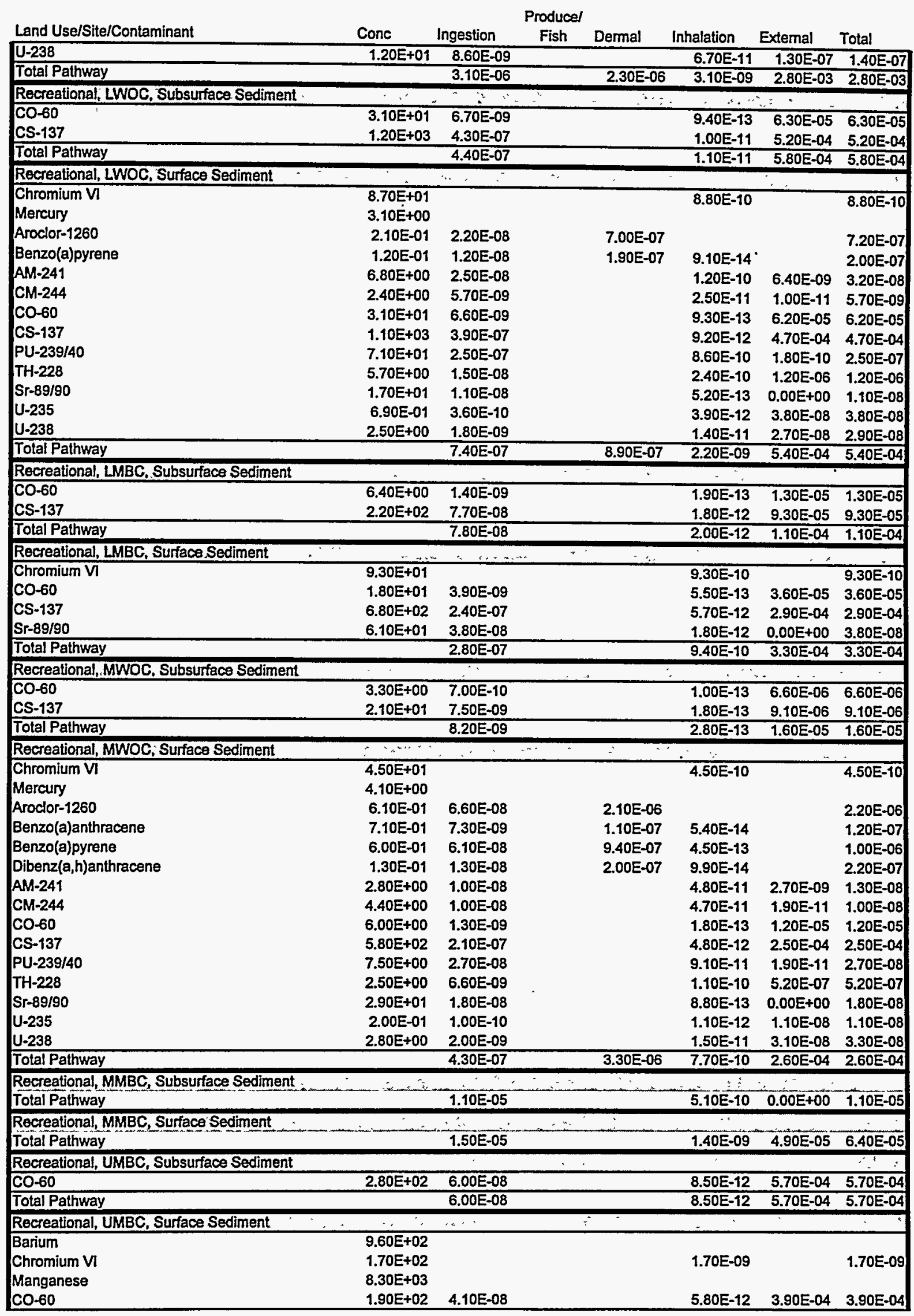




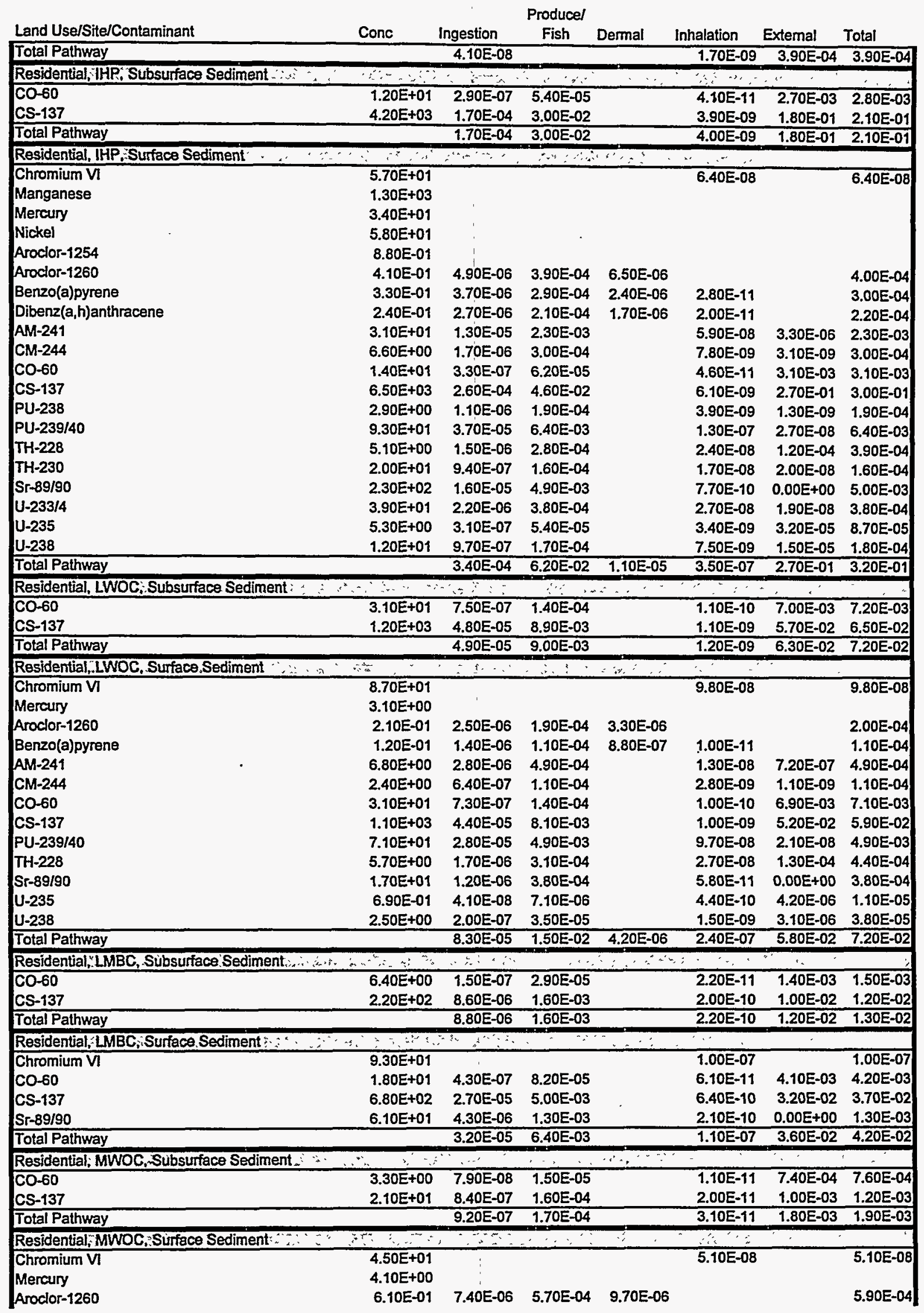




\begin{tabular}{|c|c|c|c|c|c|c|c|}
\hline \multirow[b]{2}{*}{ Land Use/Site/Contaminant } & \multirow[b]{2}{*}{ Conc } & \multirow[b]{2}{*}{ Ingestion } & \multirow{2}{*}{$\begin{array}{l}\text { Producel } \\
\text { Fish }\end{array}$} & & \multirow[b]{2}{*}{ Total } \\
\hline & & & & Dermal & Inhalation & Extemal & \\
\hline Benzo(a)anthracene & $7.10 E-01$ & $8.20 \mathrm{E}-07$ & $6.50 E-05$ & 5.20 E-07 & $6.10 E-12$ & & $6.60 \mathrm{E}-05$ \\
\hline Benzo(a)pyrene & $6.00 E-01$ & $6.80 E-06$ & $5.40 E-04$ & $4.40 E-06$ & 5.10E-11 & & $5.50 \mathrm{E}-04$ \\
\hline Dibenz(a,h)anthracene & 1.30E-01 & $1.50 \mathrm{E}-06$ & $1.20 E-04$ & $9.50 E-07$ & 1.10E-11 & & $1.20 E-04$ \\
\hline AM-241 & $2.80 E+00$ & $1.20 \mathrm{E}-06$ & $2.00 E-04$ & & 5.30E-09 & $3.00 E-07$ & 2.00E-04 \\
\hline CM-244 & $4.40 E+00$ & $1.20 E-06$ & $2.00 E-04$ & & 5.20E-09 & 2.10E-09 & $2.00 E-04$ \\
\hline$C O-60$ & $6.00 E+00$ & $1.40 E-07$ & 2.70E-05 & & $2.00 E-11$ & $1.30 E-03$ & $1.40 E-03$ \\
\hline CS-137 & $5.80 E+02$ & 2.30E-05 & 4.20E-03 & & $5.40 E-10$ & $2.70 E-02$ & $3.20 E-02$ \\
\hline PU-239/40 & $7.50 E+00$ & $3.00 \mathrm{E}-06$ & 5.20E-04 & & $1.00 E-08$ & 2.20E-09 & $5.20 E-04$ \\
\hline TH-228 & $2.50 E+00$ & $7.40 E-07$ & $1.40 E-04$ & & $1.20 \mathrm{E}-08$ & $5.80 E-05$ & 2.00E-04 \\
\hline $\mathrm{Sr}-89 / 90$ & $2.90 E+01$ & 2.00E-06 & 6.30E-04 & & $9.80 E-11$ & $0.00 E+00$ & $6.40 E-04$ \\
\hline U-235 & 2.00E-01 & $1.20 E-08$ & $2.00 E-06$ & & $1.20 \mathrm{E}-10$ & $1.20 E-06$ & $3.20 E-06$ \\
\hline U-238 & $2.80 E+00$ & 2.20E-07 & $3.90 E-05$ & & $1.70 \mathrm{E}-09$ & $3.40 E-06$ & $4.20 E-05$ \\
\hline Total Pathway & & $4.80 \mathrm{E}-05$ & $7.30 \mathrm{E}-03$ & 1.60E-05 & $8.60 \mathrm{E}-08$ & $2.90 \mathrm{E}-02$ & $3.60 \mathrm{E}-02$ \\
\hline Residential, MMBC. Subsurface Sediment & & & & & & $\therefore$ & \\
\hline Sr-89/90 & $1.70 E+04$ & $1.20 E-03$ & $3.10 \mathrm{E}-01$ & & $5.70 E-08$ & $0.00 E+00$ & $3.10 \mathrm{E}-01$ \\
\hline Total Pathway & & $1.20 E-03$ & $3.10 E-01$ & & $5.70 \mathrm{E}-08$ & $0.00 E+00$ & $3.10 E-01$ \\
\hline \multicolumn{8}{|l|}{ Residential, MMBC, Surface Sediment } \\
\hline Antimony & $1.10 E+01$ & & & & & & \\
\hline Chromium VI & 4.10E+01 & & & & 4.60E-0B & & 4.60E-08 \\
\hline Manganese & 8.20E+03 & & & & & & \\
\hline AM-241 & $3.60 \mathrm{E}+00$ & $1.50 E-06$ & $2.60 E-04$ & & $6.80 \mathrm{E}-09$ & $3.80 E-07$ & 2.60E-04 \\
\hline CM-244 & $1.00 E+01$ & 2.70E-06 & $4.70 E-04$ & & $1.20 E-08$ & 4.90E-09 & $4.80 E-04$ \\
\hline Co-60 & $2.10 E+01$ & 5.00E-07 & $9.40 \mathrm{E}-05$ & & $7.00 E-11$ & 4.70E-03 & $4.80 E-03$ \\
\hline CS-137 & $1.60 \mathrm{E}+01$ & $6.20 E-07$ & $1.10 E-04$ & & $1.50 \mathrm{E}-11$ & $7.50 E-04$ & $8.60 E-04$ \\
\hline TH-228 & $2.50 E+00$ & $7.40 E-07$ & 1.40E-04 & & $1.20 E-08$ & $5.80 E-05$ & $2.00 E-04$ \\
\hline Sr-89/90 & $2.30 E+04$ & $1.60 \mathrm{E}-03$ & $4.00 E-01$ & & 7.90E-08 & $0.00 E+00$ & $4.00 E-01$ \\
\hline U.235 & $1.80 E-01$ & 1.10E-08 & $1.90 \mathrm{E}-06$ & & 1.10E-10 & $1.10 E-06$ & $3.00 \mathrm{E}-06$ \\
\hline U-238 & $2.40 E+00$ & $1.90 E-07$ & 3.30E-05 & & $1.50 \mathrm{E}-09$ & 2.90E-06 & $3.60 E-05$ \\
\hline Total Pathway & & 1.70E-03 & $4.00 \mathrm{E}-01$ & & $1.60 E-07$ & $5.50 \mathrm{E}-03$ & $4.10 \mathrm{E}-01$ \\
\hline \multicolumn{8}{|l|}{ Residential, UMBC, Subsurface Sediment } \\
\hline $\mathrm{CO}-60$ & $2.80 E+02$ & 6.70E-06 & $1.30 \mathrm{E}-03$ & & $9.50 E-10$ & $6.20 E-02$ & $6.30 \mathrm{E}-02$ \\
\hline Total Pathway & & $6.70 E-06$ & $1.30 E-03$ & & $9.50 \mathrm{E}-10$ & $6.20 \mathrm{E}-02$ & $6.30 \mathrm{E}-02$ \\
\hline \multicolumn{8}{|l|}{ Residential, UMBC, Surface Sediment } \\
\hline Barium & $9.60 \mathrm{E}+02$ & & & & & & \\
\hline Chromium V & $1.70 E+02$ & & & & $1.90 E-07$ & & $1.90 E-07$ \\
\hline Manganese & $8.30 E+03$ & & & & & & \\
\hline co-60 & $1.90 E+02$ & $4.60 E-06$ & $8.70 E-04$ & & $6.50 \mathrm{E}-10$ & $4.30 \mathrm{E}-02$ & 4.30E-02 \\
\hline Total Pathway & & $4.60 E-06$ & $8.70 E-04$ & & $1.90 \mathrm{E}-07$ & $4.30 \mathrm{E}-02$ & 4.30E-02 \\
\hline
\end{tabular}




\section{APPENDIX B}

NONCARCINOGENIC HAZARD QUOTIENT TABLES FOR THE SEDIMENT IN FLOODPLAIN SOIL DATA USED

IN THE WAG 2 ASSESSMENT 



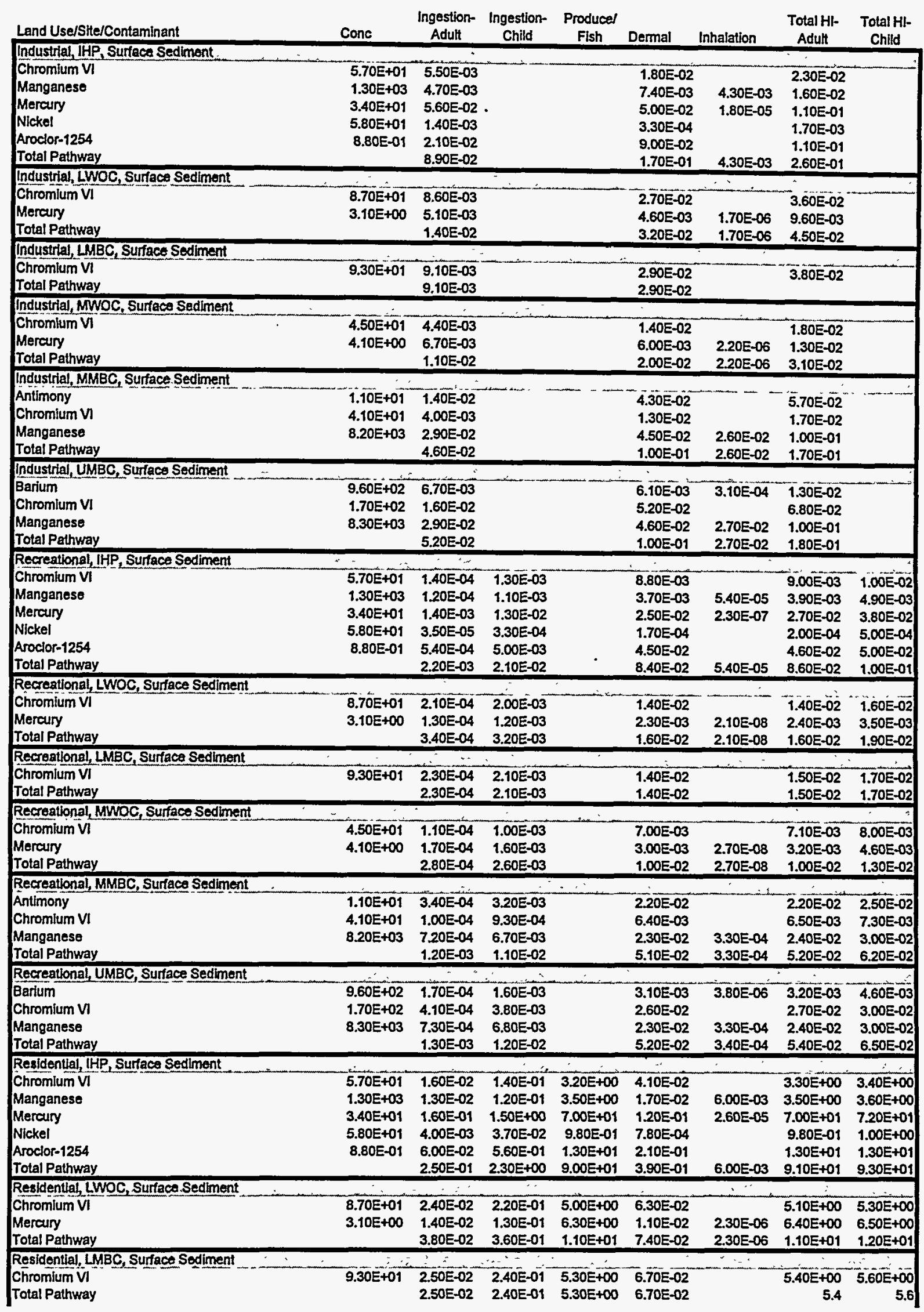




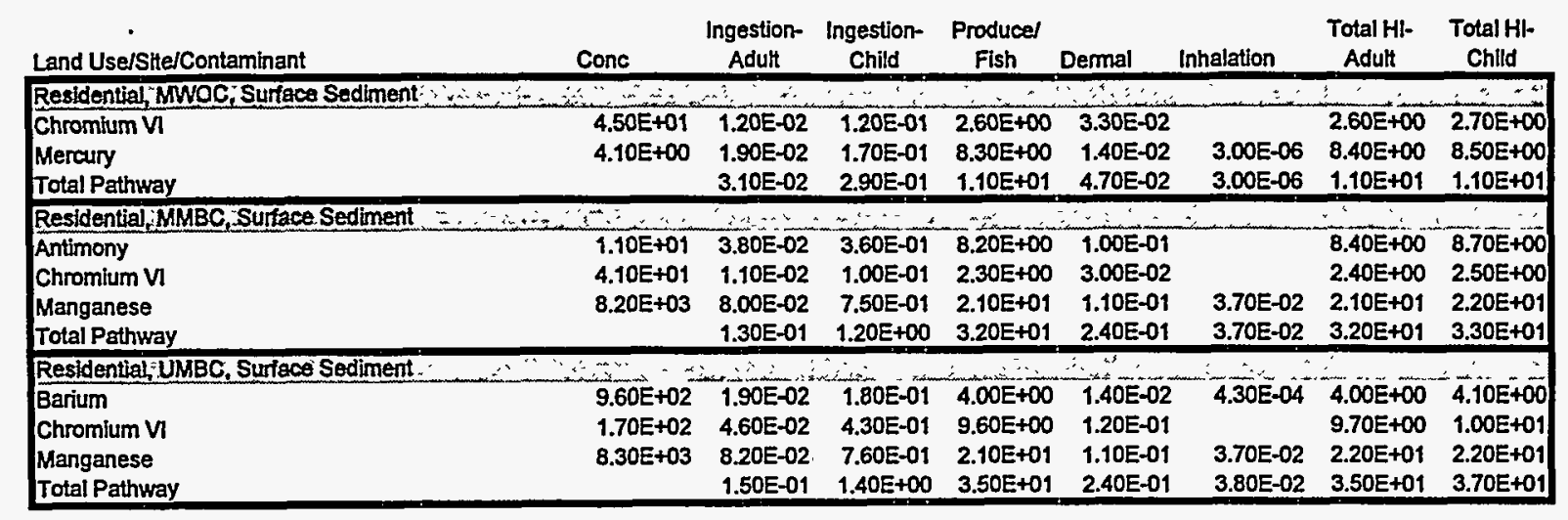




\section{APPENDIX C}

CARCINOGENIC RISK TABLES FOR THE TRIBUTARIES DATA USED IN THE WAG 2 ASSESSMENT 



\begin{tabular}{|c|c|c|c|c|c|c|c|c|}
\hline Site & Sample 10's & $\begin{array}{c}\text { Date Sample } \\
\text { Collected }\end{array}$ & $\begin{array}{c}\text { Time Sample } \\
\text { Collected }\end{array}$ & $\begin{array}{c}\text { Discharge Flow } \\
\text { (iltera/sec) }\end{array}$ & $\begin{array}{c}\text { Cestum-137 } \\
\text { Rlsk }\end{array}$ & $\begin{array}{c}\text { Cobalt }-60 \\
\text { RIsk }\end{array}$ & $\begin{array}{c}\text { Strontsum-39/so } \\
\text { Rlsk }\end{array}$ & Tritum Risk \\
\hline ESP & ESOSC02A & 11-Jan-94 & $19: 00$ & 3.2426 & 9.60E-06 & 2.50E-05 & $7.50 \mathrm{E}-05$ & 2.70E-05 \\
\hline ESP & ESPBA94 & 2B-feb-94 & $14: 50$ & 1.7813 & $2.00 E-06$ & 3.70E-05 & $5.20 E-05$ & 2.20E-05 \\
\hline ESP & ESPBB94 & 21-Mar-94 & $10: 45$ & 1.7813 & $5.30 E-06$ & $6.30 E-05$ & 4.90E-05 & $3.00 E-05$ \\
\hline ESP & ESPBC94 & 20-Apr-94 & $9: 30$ & 2.1552 & & 5.30E-05 & 2.50E-05 & $2.00 E-05$ \\
\hline ESP & ESPBD94 & 27-Apr-94 & $8: 30$ & 1.4302 & $6.10 E-06$ & 7.10E-05 & $9.30 E-05$ & $3.10 E-05$ \\
\hline ESP & ESPBE94 & 5-Jut-94 & $10: 45$ & 0.286 & & 1.10E-04 & $7.30 E-05$ & $5.20 E-05$ \\
\hline ESP & ESPGSO1 & 21-Feb-93 & $13: 00$ & 13.9618 & & $2.20 E-05$ & & $1.30 E-05$ \\
\hline ESP & ESPGS10 & 18-May-93 & $12: 00$ & 0.5579 & & 1.20E-04 & $2.10 E-05$ & 4.30E-04 \\
\hline ESP & ESPSAOIA & 18-May-93 & $23: 55$ & 2.5658 & & 5.00E-05 & 4.10E-05 & $2.50 E-0.5$ \\
\hline ESP & ESPSA02A & 19-May-93 & $0: 10$ & 4.9617 & 1.00E-05 & $3.30 E-05$ & $5.10 E-05$ & $2.00 E-05$ \\
\hline ESP & ESPSAO2B & 19-Мау-93 & $0: 10$ & 4.9617 & & $3.50 E-05$ & $2.30 E-05$ & $2.00 E-05$ \\
\hline ESP & ESPSA03A & 19-May-93 & 0.40 & 7.5671 . & & $3.40 E-05$ & $3.70 E-05$ & $1.60 E-05$ \\
\hline ESP & ESPSAO4A & 19-Мay-93 & $0: 55$ & 12.5571 & & $1.90 E-05$ & $1.30 \mathrm{E}-0.05$ & $1.20 E-05$ \\
\hline ESP & ESPSAOSA & 19-Мау-93 & $1: 10$ & 13.7409 & & 2.80E-05 & 2.90E-05 & 1.10E-05 \\
\hline ESP & ESPSAOGA & 19-4ay-93 & $1: 25$ & 12.5571 & & $3.00 E-05$ & $1.50 E-05$ & 1.10E-05 \\
\hline ESP & ESPSA07A & 19-Мау-93 & $1: 40$ & 9.8752 & $5.00 E-06$ & 3.00E-05 & 2.30E-05 & $1.20 E-05$ \\
\hline ESP & ESPSA07B & 19-May-93 & $1: 40$ & 9.8752 & & 3.20E-05 & $1.90 E-05$ & $1.20 E-05$ \\
\hline ESP & ESPSAOBA & 19-Мау-93 & $1: 55$ & 7.5671 & & $3.70 E-05$ & 1.70E-05 & $1.30 E-05$ \\
\hline ESP & ESPSA09A & 19-Мау-93 & $2: 10$ & 6.3692 & & & & \\
\hline ESP & ESPSAOSB & 19-May-93 & $2: 10$ & 6.3692 & & & & \\
\hline ESP & ESPSA1OA & 19-Мау-93 & $2: 40$ & 4.9617 & $3.80 \mathrm{E}-06$ & $3.30 E-0.5$ & $5.30 E-05$ & 1.70E-05 \\
\hline ESP & ESPSA11A & 19-Мау-93 & $9: 45$ & 3.0076 & & 5.50E-05 & $3.90 E-0.5$ & $2.30 E-05$ \\
\hline ESP & ESPSA12A & 19-Мay-93 & $15: 45$ & 1.7813 & & $5.40 E-05$ & 3.00E-05 & $2.60 E-05$ \\
\hline ESP & ESPSA13A & 19-Мау-93 & $19: 45$ & 1.4302 & & & & \\
\hline ESP & ESPSA13B & 19-May-93 & $19: 45$ & 1,4302 & & & & \\
\hline ESP & ESPSA14A & $20-M a y-93$ & $3: 45$ & 17.9152 & & 6.10E-05 & 5.60E-0.5 & $3.00 E-05$ \\
\hline ESP & ESPSA15A & 19-May-93 & $0: 25$ & 5.6385 & & $3.30 E-05$ & 2.20E-05 & 1.70E-05 \\
\hline ESP & ESPSA16A & 19-Мау-93 & $2: 25$ & 5.6385 & & 3.30E-05 & $1.80 E-05$ & $1.70 E-05$ \\
\hline ESP & ESPSB01A & $7-J a n-94$ & $12: 15$ & 4.7776 & & 2.20E-05 & 6.30E-05 & 2.20E-05 \\
\hline ESP & ESPSB02A & 7-Jan-94 & $14: 30$ & 7.0857 & & $3.10 E-05$ & 2.80E-05 & 2.00E-05 \\
\hline ESP & ESPSB03A & 7-Jan-94 & $16: 45$ & 4.4434 & & 2.30E-05 & $4.00 E-05$ & $1.90 E-05$ \\
\hline ESP & ESPSBOAA & 7-Jan-94 & $19: 00$ & 4.1234 & & $3.40 E-0.5$ & 5.10E-05 & $1.90 E-05$ \\
\hline ESP & ESPSB05A & 8-Jan-94 & $0: 00$ & 3.8175 & & 3.10E-05 & $1.50 \mathrm{E}-04$ & $9.10 E-05$ \\
\hline ESP & ESPSCO4A & 12-Jan-94 & $14: 30$ & 16.6267 & & $1.80 E-05$ & $4.00 E-05$ & $1.70 E-05$ \\
\hline ESP & ESPSCOIA & $11-\operatorname{Jan}-94$ & $18: 00$ & 2.039 & & $1.90 E-05$ & $3.90 E-05$ & 2.30E-05 \\
\hline ESP & ESPSCO3A & 11-Jan-94 & 20.30 & 5.8651 & & 2.10E-05 & $5.80 E-05$ & $2.00 E-05$ \\
\hline ESP & ESPSD01A & 25-Jan-94 & $14: 15$ & 2.7244 & & 3.10E-05 & $6.50 E-05$ & $1.80 E-0.5$ \\
\hline ESP & ESPSD02A & 25-Jan-94 & $15: 15$ & 7.9721 & $1.00 E-05$ & $1.90 E-05$ & $5.90 \mathrm{E}-05$ & $1.40 E-05$ \\
\hline ESP & ESPSD03A & 25-Jan-94 & $16: 45$ & 13.9618 & & $220 E-05$ & 4.00E-05 & $1.20 E-05$ \\
\hline ESP & ESPSDO4A & 25-Jan-94 & $17: 15$ & 16.6267 & $3.20 E-06$ & $2.60 E-05$ & $3.40 E-05$ & $1.20 \mathrm{E}-0.05$ \\
\hline ESP & ESPSD05A & 25-Jan-94 & $17: 45$ & 18.0597 & & 2.40E-05 & 1.60E-05 & $1.00 E-05$ \\
\hline ESP & ESPSDO6A & 25-Jan-94 & $18: 45$ & 16.6267 & & 2.10E-05 & 2.20E-05 & $9.70 E-06$ \\
\hline ESP & ESPSD07A & 25-Jan-94 & $20: 15$ & 12.1351 & & 2.00E-05 & 6.80E-05 & 2.00E-05 \\
\hline ESP & ESPSDOBA & 25-Jan-94 & $22: 45$ & 9.4164 & & $2.00 E-05$ & 5.00E-05 & 1.00E-05 \\
\hline ESP & ESPSDOSA & 26-Jan-94 & $7: 45$ & 5.1259 & & $2.20 E-05$ & $5.40 E-05$ & 1.20E-05 \\
\hline ESP & ESPSD10A & 26-Jan-94 & $13: 45$ & 4.4434 & & $1.90 E-05$ & $5.505-05$ & $1.40 E-05$ \\
\hline ESP & ESPSD11A & 25-Jan-94 & $16: 15$ & 8.918 & & $2.00 E-05$ & $1.30 E-05$ & $1.40 E-05$ \\
\hline ESP & ESPSD118 & 25-Jan-94 & $16: 15$ & 8.918 & & 2.70E-05 & $2.90 E-05$ & $2.00 E-05$ \\
\hline ESP & ESPSD14A & $31-J a n-94$ & 9.45 & 1.1441 & & 2.70E-05 & $7.10 E-05$ & 1.90E-05 \\
\hline ESP & ESPSD15A & 28-Jan-94 & $2: 00$ & 21.1352 & & $1.80 E-05$ & 4.60E-05 & $7.60=-06$ \\
\hline ESP & ESPSD16A & 28-Jan-94 & $4: 00$ & 20.3479 & & $1.10 E-05$ & $2.00 E-05$ & 7.40E-06 \\
\hline ESP & ESPSE01A & 1-Mar-94 & $12: 00$ & 3.254 & & $3.70 \mathrm{E}-05$ & $6.80 E-05$ & 1.70E-05 \\
\hline ESP & ESPSE0Ia & 1-Mar-94 & $12: 00$ & 3.254 & & $3.00 E-05$ & $6.80 E-05$ & $1.70 E-05$ \\
\hline ESP & ESPSE02A & 1-Mar-94 & $13: 00$ & 8.0032 & & & $4.10 E-05$ & $1.30 E-05$ \\
\hline ESP & ESPSE03A & 1-Mar-94 & $15: 00$ & 13.149 & & $2.30 E-0.5$ & - 1.60E-05 & $9.90 E-06$ \\
\hline ESP & ESPSEO3a & 1-Mar-94 & $15: 00$ & 13.149 & & $2.00 E-05$ & $1.60 E-05$ & 9.90E-06 \\
\hline ESP & ESPSE04A & $1+$ Mar-94 & $16: 00$ & 16.3067 & & $1.50 \mathrm{E}-05$ & 7.80E-05 & $9.20 E-06$ \\
\hline ESP & ESPSE05A & 1-Mar-94 & $17: 00$ & 18.4165 & & 2.10E-05 & 7.80E-05 & $8.00 E-06$ \\
\hline ESP & ESPSEOGA & 1-Mar-94 & $19: 00$ & 14.3667 & & $2.10 E-05$ & $4.10 E-05$ & $8.20 E-06$ \\
\hline ESP & ESPSE06a & 1-Mar-94 & 19:00 & 14.3667 & & $1.50 E-05$ & 4.10E-0.5 & 8.20E-06 \\
\hline ESP & ESPSE07A & 2-Mar-94 & 0.00 & 11.9935 & & $1.80 E-05$ & 4.50E-05 & $9.30 \mathrm{E}-06$ \\
\hline ESP & ESPSEORA & 2-Mar-94 & $3: 30$ & 10.9032 & & $1.40 E-05$ & $3.30 E-05$ & $8.60 E-06$ \\
\hline ESP & ESPSEOBC & $2+$ Mar-94 & $3: 30$ & 10.9032 & & $4.20 E-05$ & & 9.50E-06 \\
\hline ESP & ESPSEOOA & $2-\mathrm{Mar}-94$ & $7: 30$ & 12.5571 & & & $4.10 E-05$ & $7.50 \mathrm{E}-06$ \\
\hline ESP & ESPSEOSC & 2-Mar-94 & $7: 30$ & 12.5571 & & & $6.90 E-05$ & $8.40 E-06$ \\
\hline ESP & ESPSEIOA & 2-Mar-94 & $8: 30$ & 17.0005 & & & $4.60 E-05$ & $5.70 E-06$ \\
\hline ESP & ESPSE11A & 2-Mar-94 & 9:30 & 33.3213 & & & 4.60E-05 & $5.20 E-06$ \\
\hline ESP & ESPSE11B & 2-Mar-94 & $9: 30$ & 33.3213 & & & $8.20 E-05$ & $5.80 E-06$ \\
\hline ESP & ESPSE12A & 2-Mar-94 & $10: 00$ & 42.1855 & & $9.10 E-06$ & $5.20 E-05$ & $5.00 E-06$ \\
\hline ESP & ESPSE13A & 2-Mar-94 & $10: 30$ & 40.9932 & & & 6.00E-05 & $4.80 \mathrm{E}-06$ \\
\hline ESP & ESPSE14A & $2-$ Mar-94 & $11: 30$ & 30.3166 & & & & 8.30E-06 \\
\hline ESP & ESPSE14B & $2-\operatorname{Mar}-94$ & $11: 30$ & 30.3166 & & & 7.80E-05 & $4.30 E-06$ \\
\hline ESP & ESPSE15A & $2+M a r-94$ & $12: 30$ & 25.6749 & & & $6.40 E-05$ & 4.90E-06 \\
\hline ESP & ESPSE16A & 2+Mar-94 & $13: 30$ & 23.1233 & & & 6.40E-0.5 & $4.60 E-06$ \\
\hline ESP & ESPSE17A & $2+$ Mar-94 & $17: 00$ & 16.3067 & & & $5.50 E-05$ & $7.50 \mathrm{E}-06$ \\
\hline ESP & ESPSE18A & 2+Mar-94 & $21: 30$ & 13.7409 & & & $6.00 E-05$ & $5.60 E-06$ \\
\hline ESP & ESPSE19A & $3-\mathrm{Mar}-94$ & $3: 30$ & 9.8752 & & & 4.60E-05 & 7.10 E-06 \\
\hline ESP & ESPSE20A & 3-Mar-94 & $11: 30$ & 6.7487 & & & $3.70 E-05$ & $8.80 E-06$ \\
\hline ESP & ESPSE21A & 3-Mar-94 & $23: 30$ & 4.6388 & & $1.40 E-05$ & 2.20E-03 & $1.20 E-05$ \\
\hline ESP & ESPSE22A & 5-Mar-94 & $11: 30$ & 3.0076 & & & $6.50 E-03$ & $1.50 \mathrm{E}-0.5$ \\
\hline
\end{tabular}




\begin{tabular}{|c|c|c|c|c|c|c|c|c|}
\hline Site & Sample ID's & $\begin{array}{c}\text { Date Sample } \\
\text { Collected }\end{array}$ & $\begin{array}{c}\text { Time Sample } \\
\text { Collected }\end{array}$ & $\begin{array}{c}\text { Discharge Flow } \\
\text { (litera/sec) }\end{array}$ & $\begin{array}{c}\text { Ceslum-137 } \\
\text { Risk }\end{array}$ & $\begin{array}{l}\text { Cobalt }-60 \\
\text { Risk }\end{array}$ & $\begin{array}{c}\text { Strontuum-89/90 } \\
\text { RJsk }\end{array}$ & Tritium Risk \\
\hline ESP & ESPSF01A & 13-Jul-94 & $21: 25$ & 0.9997 & & & $3.80 E-05$ & $4.80 \mathrm{E}-05$ \\
\hline ESP & ESPSGOI-MS & 5-Aug-94 & $4: 15$ & 2.7244 & & & $3.00 E-02$ & 4.40E-05 \\
\hline ESP & ESPSG01A & 5-Aug-94 & $4: 15$ & 2.7244 & • & 5.10E-05 & & $4.40 E-05$ \\
\hline ESP & ESPSG01A-D & 5-Aug-94 & $4: 15$ & 2.7244 & & $5.00 E-05$ & & $4.40 E-05$ \\
\hline ESP & ESPSG02A & 5-Aug-94 & $4: 30$ & 7.519 & & $1.70 E-05$ & $1.30 E-05$ & $2.00 E-05$ \\
\hline ESP & ESPSGO3A & 5-Aug-94 & $4: 45$ & 7.0857 & & 2.10E-05 & & $1.70 E-05$ \\
\hline ESP & ESPSGO4A & 5-Aug-94 & $5: 00$ & 7.9721 & 2.80E-06 & 2.30E-05 & & $1.90 E-05$ \\
\hline ESP & ESPSG05A & 5-Aug-94 & $5: 30$ & 5.4884 & & $2.50 E-05$ & & $1.90 E-05$ \\
\hline ESP & ESPSGO6A & 5-Aug-94 & $5: 45$ & 4.1234 & & $3.00 E-05$ & $8.80 E-03$ & 2.10E-05 \\
\hline ESP & ESPSG07A & 5-Aug-94 & $6: 00$ & 3.523 & & $3.20 E-05$ & & 2.20E-05 \\
\hline ESP & ESPSGOSA & 5-Aug-94 & $7: 30$ & $\mathbf{3 . 5 2 3}$ & & & & $3.10 E-05$ \\
\hline ESP & ESPSGO9A & 5-Aug-94 & $9: 00$ & 1.2999 & & & & $3.40 E-05$ \\
\hline ESP & ESPSG1OA & 5-Aug-94 & $14: 00$ & 0.7448 & & & & $3.80 E-05$ \\
\hline ESP & ESPSG11A & 6-Aug-94 & $16: 00$ & 0.2237 & & 7.10E-05 & & $4.80 E-05$ \\
\hline HRT & ESPSGO3C & 5-Aug-94 & $4: 45$ & 7.0857 & & $2.10 \mathrm{E}-05$ & 4.20E-05 & $1.70 E-05$ \\
\hline HRT & HRTBA94 & 28-Feb-94 & 15:15 & 5.9812 & & & $2.20 E-03$ & $1.50 E-06$ \\
\hline HRT & HRTBB94 & $21+$ Mar-94 & 11:15 & 3.3757 & & & $1.30 \mathrm{E}-03$ & $1.10 E-06$ \\
\hline HRT & HRTBC94 & 29-Apr-94 & $10: 00$ & 4.905 & & & $9.40 E-04$ & $1.00 E-06$ \\
\hline HRT & HRTBD94 & 27-Apr-94 & $9: 00$ & 4.2537 & 8.50E-06 & & 8.60E-04 & $1.50 E-06$ \\
\hline HRT & HRTBE94 & 5-Jun-94 & $11: 15$ & 3.1095 & & & $7.20 E-04$ & $1.20 E-06$ \\
\hline HRT & HRTGSO1 & 21-Feb-93 & $13: 15$ & 1.9597 & & & $1.00 E-03$ & $1.40 E-06$ \\
\hline HRT & HRTGS10-1 & 18-May-93 & $12: 15$ & 1.9597 & $3.90 E-06$ & & $1.20 E-03$ & 5.80E-07 \\
\hline HRT & HRTSA01A & 18-May-93 & $23: 55$ & 5.2505 & $6.70 E-06$ & & $1.10 E-03$ & \\
\hline HRT & HRTSAO2A & 19-May-93 & $0: 25$ & 9.4674 & & & $1.20 E-03$ & \\
\hline HRT & HRTSAC3A & 19-May-93 & $0: 40$ & 24.089 & & & $1.20 E-03$ & \\
\hline HRT & HRTSAO3B & $19-$ Мау-93 & $0: 40$ & 24.089 & & & $1.10 E-03$ & $5.60 E-08$ \\
\hline HRT & HRTSAOAA & 19-May-93 & $0: 55$ & 31.3871 & & & $9.90 \mathrm{E}-04$ & $3.10 E-07$ \\
\hline HRT & HRTSA05A & 19-Мay-93 & $1: 10$ & 48.144 & & & $1.00 E-03$ & 5.10E-07 \\
\hline HRT & HRTSAOSA & 19-May-93 & $1: 25$ & 46.8979 & & & $9.20 E-04$ & $9.10 E-08$ \\
\hline HRT & HRTSAOTA & 19-Мау-93 & $1: 40$ & 39.8151 & & & 9.20E-04 & $3.40 \mathrm{E}-07$ \\
\hline HRT & HRTSA09A & 19-May-93 & $2: 10$ & 24.9414 & & & $9.20 E-04$ & 2.10E-07 \\
\hline HRT & HRTSA1OB & 19-Мау-93 & $2: 25$ & 20.8492 & & & $1.10 E-03$ & \\
\hline HRT & HRTSA11A & 19-May-93 & $2: 40$ & 17.1732 & & & 1.20E-03 & \\
\hline HRT & HRTSA11B & 19-May-93 & $2: 40$ & 17.1732 & $6.40 E-07$ & & $1.10 E-03$ & 1.20E-07 \\
\hline HRT & HRTSA12A & 19-May-93 & $2: 55$ & 15.1597 & & & $1.30 E-03$ & 4.10E-06 \\
\hline HRT & HRTSA13B & 19-May-93 & $9: 15$ & 8.0514 & & & $1.60 E-03$ & $3.20 E-07$ \\
\hline HRT & HRTSA14A & 19-Мау-93 & $13: 15$ & 5.2505 & & & $1.80 E-03$ & $3.70 E-08$ \\
\hline HRT & HRTSA1GA & 20-May-93 & $1: 15$ & 3.3757 & & & $1.90 E-03$ & $1.90 \mathrm{E}-06$ \\
\hline HRT & HRTSBO1A & 7-Jan-94 & $13: 00$ & 22.4351 & & & $5.20 E-04$ & 5.90E-06 \\
\hline HRT & HRTSBO2A & $7-J a n-94$ & $15: 00$ & 32.3783 & & & $5.40 E-04$ & $6.90 E-06$ \\
\hline HRT & HRTSBO3A & 7-Jan-94 & $16: 45$ & 44.4624 & & & $4.20 E-04$ & $7.00 E-05$ \\
\hline HRT & HRTSBOAA & 7-Jan-94 & $19: 00$ & 37.6005 & & & $5.00 \mathrm{E}-04$ & $5.90 E-06$ \\
\hline HRT & HRTSCOIA & 11 -Jan-94 & $19: 15$ & 19.3312 & & & $7.40 E-04$ & $5.50 E-06$ \\
\hline HRT & HRTSCO2A & 11-Jan-94 & $19: 30$ & 21.6336 & & & 7.20E-04 & $6.00 E-06$ \\
\hline HRT & HRTSCO2B & 11-Jan-94 & $19: 30$ & 21.6336 & & & 7.00E-04 & \\
\hline HRT & HRTSCO3A & $11-J a n-94$ & $20: 30$ & 31.3871 & & & $6.20 \mathrm{E}-04$ & $2.50 E-05$ \\
\hline HRT & HRTSD02A & 25-Jan-94 & 15:10 & 40.9507 & & & $9.80 E-04$ & $8.20 E-07$ \\
\hline HRT & HRTSD03A & $25-\operatorname{Jan}-94$ & $16: 10$ & 64.5781 & & & $9.30 E-04$ & $1.00 E-06$ \\
\hline HRT & HRTSDOAA & 25-Jan-94 & $17: 10$ & 89.1032 & $3.50 E-06$ & & 8.00E-04 & $3.40 E-07$ \\
\hline HRT & HRTSD05A & 25-Jan-94 & $17: 40$ & 82.1195 & & & $7.80 E-04$ & $2.40 E-06$ \\
\hline HRT & HRTSDOSA & 25-Jan-94 & $18: 10$ & 70.6782 & & & $8.50 E-04$ & $1.10 E-06$ \\
\hline HRT & HRTSDOTA & 25-Jan-94 & $20: 10$ & 56.017 & & & $8.60 E-04$ & $6.00 E-07$ \\
\hline HRT & HRTSDOBA & 25-Jan-94 & $23: 10$ & 43.273 & & & $9.70 E-04$ & 8.70E-07 \\
\hline HRT & HRTSDO9A & $26-\sqrt{a n-94}$ & $5: 10$ & 33.3864 & & & 9.90E-04 & $1.00 E-06$ \\
\hline HRT & HRTSD10A & 26-Jar-94 & $13: 10$ & 28.5211 & & & $9.90 E-04$ & $1.00 \mathrm{E}-06$ \\
\hline HRT & HRTSDI1A & 25-Jan-94 & $15: 40$ & 56.017 & & & 8.70E-04 & 2.30E-06 \\
\hline HRT & HRTSD11B & 25-Jan-94 & $15: 40$ & 56.017 & & & 8.60E-04 & 1.00E-06 \\
\hline HRT & HRTSD15A & 31 -Jan-94 & $9: 15$ & 5.9812 & & & $1.40 E-03$ & $1.30 E-06$ \\
\hline HRT & HRTSD16A & 28-Jan-94 & $2: 00$ & 108.0096 & & & $6.60 E-04$ & $1.70 E-06$ \\
\hline HRT & HRTSD17A & 28-Jan-94 & $4: 00$ & 98.2959 & & & $6.60 E-04$ & $5.20 \mathrm{E}-06$ \\
\hline HRT & HRTSDOIA & 25-Jan-94 & $13: 40$ & 13.8995 & & & $1.00 E-03$ & 4.50E-07 \\
\hline HRT & HRTSEOIA & 1-Mar-94 & $12: 20$ & 12.1238 & & & 2.10E-03 & $1.30 E-06$ \\
\hline HRT & HRTSE02A & 1-Mar-94 & $12: 50$ & 20.0817 & & & 2.10E-03 & 8.50E-07 \\
\hline HRT & HRTSE03A & 1-Mar-94 & $13: 50$ & 44.4624 & & & $2.10 E-03$ & $1.10 \mathrm{E}-06$ \\
\hline HRT & HRTSEOAA & 1-Mar-94 & $14: 50$ & 63.1026 & & & 2.00E-03 & $1.50 \mathrm{E}-06$ \\
\hline HRT & HRTSE05A & $1-\operatorname{Mar}-94$ & $15: 50$ & 80.426 & & & $1.60 E-03$ & $1.30 E-06$ \\
\hline HRT & HRTSEOTA & 1-Mar-94 & $18: 50$ & 69.1235 & & & $1.40 E-03$ & $1.10 \mathrm{E}-06$ \\
\hline HRT & HRTSEOBA & 2-Mar-94 & $0: 20$ & 56.017 & & & $2.40 E-03$ & 9.30E-07 \\
\hline HRT & HRTSEOSA & 2-Mar-94 & $3: 20$ & 49.4099 & & & $3.20 E-03$ & $1.30 E-06$ \\
\hline HRT & HRTSE10A & 2-Mar-94 & $6: 50$ & 40.9507 & & & 3.70E-03 & 9.10E-07 \\
\hline HRT & HRTSEIIA & 2-Mar-94 & $7: 50$ & 69.1235 & & & $3.30 E-03$ & $7.005-07$ \\
\hline HRT & HRTSE12A & 2+Mar-94 & 8:50 & 106.0244 & & & 3.10E-03 & 1.70E-06 \\
\hline HRT & HRTSE13A & 2-Mar-94 & $9: 50$ & 157.1307 & & & 2.20E-03 & $9.80 E-07$ \\
\hline HRT & HRTSE13CD & 2-Mar-94 & $9: 50$ & 157.1307 & & & $2.20 E-03$ & 1.10E-06 \\
\hline HRT & HRTSE14A & 2+Mar-94 & $10: 20$ & 167.2069 & & & 2.30E-03 & $7.80 E-07$ \\
\hline HRT & HRTSE15A & 2-Mar-94 & $10: 50$ & 147.4113 & & & 2.30E-03 & $1.10 \mathrm{E}-06$ \\
\hline HRT & HRTSE15C & 2-Mar-94 & 10.50 & 147.4113 & & & 2.30E-03 & $1.10 E-06$ \\
\hline HRT & HRTSE16A & 2-Mar-94 & $11: 50$ & 124.6561 & & & $2.50 \mathrm{E}-03$ & $1.30 \mathrm{E}-06$ \\
\hline HRT & HRTSE17A & 2-Mar-94 & $12: 20$ & 114.0928 & & & 2.60E-03 & $8.70 E-07$ \\
\hline HRT & HRTSE17C & 2-Mar-94 & $12: 20$ & 114.0928 & & & 2.60E-03 & $1.10 \mathrm{E}-06$ \\
\hline
\end{tabular}




\begin{tabular}{|c|c|c|c|c|c|c|c|c|}
\hline Site & Sample ID's & $\begin{array}{c}\text { Date Sample } \\
\text { Collected }\end{array}$ & $\begin{array}{c}\text { Time Sample } \\
\text { Collected } \\
\end{array}$ & $\begin{array}{l}\text { Discharge Flow } \\
\text { (ilters/sec) }\end{array}$ & $\begin{array}{c}\text { Cesium-137 } \\
\text { Risk }\end{array}$ & $\begin{array}{l}\text { Cobalt } 60 \\
\text { Risk }\end{array}$ & $\begin{array}{c}\text { Strontium-89/90 } \\
\text { Risk }\end{array}$ & Tritum Rlsk \\
\hline HRT & HRTSE18C & 2 -Mar-94 & $13: 50$ & 92.7197 & & & $3.00 E-03$ & $1.20 E-06$ \\
\hline HRT & HRTSE19A & 2-Mar-94 & 15:50 & 80.426 & & & $3.20 E-03$ & 8.80E-07 \\
\hline HRT & HRTSE2OA & 2-Mar-94 & 21:50 & 54.6576 & & & $3.30 E-03$ & $7.80 \mathrm{E}-07$ \\
\hline HRT & HRTSE21A & 3-Mar-94 & $3: 50$ & 36.5215 & & & $2.50 E-03$ & $1.50 E-06$ \\
\hline HRT & HRTSE22A & 3-Mar-94 & 7:50 & 27.6007 & & & $2.30 E-03$ & $1.10 E-06$ \\
\hline HRT & HRTSE24A & 3-Mar-94 & 23:50 & 14.5225 & & 3.00E-05 & 2.20E-03 & $1.00 E-06$ \\
\hline HRT & HRTSE25A & 5-Mar-94 & 11:50 & 8.0514 & & 3.00E-05 & $6.50 E-03$ & $1.40 E-06$ \\
\hline HRT & HRTSEOGA & 1-Mar-94 & 17:20 & 82.1195 & & & $1.30 E-03$ & $8.80 E-07$ \\
\hline HRT & HRTSF01 & 13-Jut-94 & 21:45 & 5.9812 & & & $1.20 E-03$ & 4.80E-07 \\
\hline HRT & HRTSHO1 & 14-Aug-94 & $19: 05$ & 11.0165 & & & $3.60 E-04$ & $3.60 E-07$ \\
\hline HRT & HRTSHO2 & 14-Aug-94 & 19:35 & 135.7378 & $1.90 E-06$ & & 2.80E-04 & \\
\hline HRT & HRTSH03 & 14Aug-94 & $20: 05$ & 112.0452 & & & 4.40E-04 & $3.50 E-08$ \\
\hline HRT & HRTSHOA & 14-Aug-94 & 20:35 & 66.0734 & & & $6.80 E-04$ & \\
\hline HRT & HRTSHOAC & 14-Aug-94 & $20: 35$ & 66.0734 & & & 6.60E-04 & \\
\hline |HRT & HRTSH05 & 14-Aug-94 & 21:05 & 37.6005 & & & $7.80 E-04$ & 4.50E-07 \\
\hline HRT & HRTSHOS & 14-Aug-94 & 21:35 & 24.9414 & & & $9.40 E-04$ & $1.30 E-07$ \\
\hline HRT & HRTSHO7 & 14-Aug-94 & 22:05 & 18.5949 & $3.80 E-06$ & & $9.90 E-04$ & $3.70 E-07$ \\
\hline HRT & HRTSH08 & 15-Aug-94 & $2: 05$ & 8.0514 & & & $1.30 E-03$ & \\
\hline HRT & HRTSHOS & 15-Aug-05 & $7: 35$ & 5.2505 & & & $1.30 E-03$ & \\
\hline HRT & HRTSH10 & 15-Aug-94 & 18:35 & 4.2537 & & & $1.30 E-03$ & $1.80 E-07$ \\
\hline HRT & HRTSH12 & 15-Aug-94 & 1:05 & 8.9803 & & & $1.30 E-03$ & \\
\hline HRT & HRTSH13a & 15-Aug-94 & 4:35 & 6.3663 & $6.10 E-06$ & & & \\
\hline HRT & HRTSH13b & 15-Aug-94 & 4:35 & 6.3663 & & & & \\
\hline Msi & MS1BA94 & 28-Feb-94 & 16:00 & 0.0668 & $8.00 E-06$ & & $1.20 \mathrm{E}-02$ & $8.80 E-03$ \\
\hline MS1 & MS1BC94 & 20-Apr-94 & 13:25 & 0.589 & & & $1.10 E-02$ & $5.70 E-03$ \\
\hline MSi & MS18D94 & 27-Apr-94 & 10:15 & 0.0225 & & & $1.10 E-02$ & $6.20 E-03$ \\
\hline MS1 & MS1BD94D & 27-Apr-94 & 10:15 & 0.0225 & & & $1.10 E-02$ & 6.30E-03 \\
\hline MS1 & MS1BE94 & 20-Jun-94 & $8: 15$ & 0.0001 & & & $1.10 E-02$ & $9.60 E-03$ \\
\hline MS1 & MS1BF94 & 11-Jut-94 & 12:10 & 0.3172 & & & $1.00 E-02$ & 8.60E-03 \\
\hline MS1 & MS1BG94 & 25-Augg-94 & 10:10 & 0.4106 & & & $1.30 E-02$ & $2.60 E-02$ \\
\hline MS1 & MSIBGSAD & 25-Aug-94 & 10:00 & 0.4106 & & & $1.30 E-02$ & $2.60 E-02$ \\
\hline MS1 & MS1BH94 & 4-Sep-94 & 11:30 & 0.1133 & & & $1.40 E-02$ & 2.30E-02 \\
\hline MS1 & MS1BI940 & 20-Sep-94 & 11:00 & 0.1671 & $3.60 E-06$ & & $1.40 E-02$ & $2.40 E-02$ \\
\hline MS1 & MS1GS10-2 & 19-May-93 & 14:00 & 2.041 & & & $1.30 E-02$ & $7.00 E-03$ \\
\hline MS1 & MS1GSO1 & 21-Feb-93 & 13:45 & 2.041 & $6.10 E-06$ & & $5.90 E-03$ & B.50E-03 \\
\hline MS1 & MS1SAO1A & 19-May-93 & $0: 30$ & 2.3055 & & & 9.50E-03 & $6.00 E-03$ \\
\hline MS1 & MS1SA02A & 19-May-93 & $0: 45$ & 7.112 & & & $6.20 E-03$ & $3.90 E-03$ \\
\hline MS1 & MS1SADOBA & 19-May-93 & $1: 00$ & 8.7755 & & & $7.00 E-03$ & $4.80 E-03$ \\
\hline MS1 & MS1SA04A & 19-May-93 & 1:15 & 8.7755 & 4.30E-06 & & $7.10 E-03$ & $5.40 E-03$ \\
\hline MS1 & MS1SA04B & 19-Мау-93 & 1:15 & 8.7755 & & & $7.10 E-03$ & $5.30 E-03$ \\
\hline MS1 & MS1SA05A & 19-Мау-93 & 1:30 & 7.112 & & & 6.80E-03 & $5.50 \mathrm{E}-03$ \\
\hline MS1 & MS1SA06A & 19-May-93 & 1:45 & 5.6375 & $8.90 E-07$ & & $7.10 E-03$ & $6.00 E-03$ \\
\hline MS1 & MS1SADBA & 19-May-93 & 2:15 & 4.3479 & & & 8.00E-03 & $6.20 E-03$ \\
\hline MS1 & MS1SAOSA & 19-Мау-93 & $2: 30$ & 3.2389 & & & $8.40 E-03$ & $6.20 E-03$ \\
\hline MS1 & MS1SA09B & 19-May-93 & $2: 30$ & 3.2389 & & & $8.50 E-03$ & $6.40 E-03$ \\
\hline MS1 & MSISAI1A & 19-Маy-93 & 3:00 & 3.2389 & $4.60 E-06$ & & $9.50 E-03$ & $6.30 E-03$ \\
\hline MS1 & MS1SA12A & 19-May-93 & 3:15 & 3.2389 & & & $9.80 E-03$ & $7.20 E-03$ \\
\hline MS1 & MS1SA13A & 19-May-93 & $3: 30$ & 2.3055 & & & $1.20 E-02$ & $7.70 E-03$ \\
\hline MS1 & MSISA14A. & 19-May-93 & $4: 45$ & 2.3055 & & & 1.10E-02 & $1.00 \mathrm{E}-02$ \\
\hline MSi & MS1SA15A & 19-Мау-93 & 13:05 & 1.5423 & & & $1.00 E-02$ & $8.40 E-03$ \\
\hline MS1 & MS1SA16A & 20-May-93 & 1:05 & 0.5 & $1.40 E-06$ & & $1.30 E-02$ & $7.90 E-03$ \\
\hline MS1 & MS1SB01A & 7.Jan-94 & $13: 00$ & 10.4104 & & & $9.40 E-03$ & $1.30 E-02$ \\
\hline MS1 & MS1SB02A & 7-Jan-94 & $14: 45$ & 14.9813 & $2.80 E-06$ & & $9.20 E-03$ & $1.30 E-02$ \\
\hline MS1 & MS1SB03A & 7-Jan-94 & $17: 00$ & 17.2214 & $3.90 E-06$ & & $8.00 E-03$ & $1.30 E-02$ \\
\hline MS1 & MS1SB03C & 7-Jan-94 & 17:00 & 17.2214 & $2.20 E-06$ & & $8.10 E-03$ & $1.30 E-02$ \\
\hline MS1 & MS1SB04A & 8-Jan-94 & $0: 15$ & 8.7254 & & & $8.00 E-03$ & $1.60 E-02$ \\
\hline MS1 & MS1SC01A & 11-Jan-94 & 19:25 & 7.2018 & $2.30 E-06$ & & $1.20 E-02$ & $1.50 E-02$ \\
\hline MS1 & MS1SCO2A & 11-Jan-94 & $20: 40$ & 12.9111 & & & 1.20E-02 & $1.50 E-02$ \\
\hline MS1 & MS1SCO3A & 11 Jan-94 & $22: 25$ & 19.6343 & & & $9.20 E-03$ & $9.60 E-03$ \\
\hline MS1 & MSISCOAA & 11-Jan-94 & $22: 40$ & 23.1204 & & & $8.60 E-03$ & $8.70 E-03$ \\
\hline MS1 & MS1SCO5A & 12-Jan-94 & 15:05 & 7.2018 & & & 9.30E-03 & $1.10 E-02$ \\
\hline MS1 & MSISD01A & 25-Jan-94 & $14: 10$ & 6.7288 & & & $1.10 E-02$ & $1.40 \varepsilon-02$ \\
\hline MSt & MS1SD02A & 25-Jan-94 & 15:10 & 21.3391 & & & $8.80 E-03$ & $1.00 E-02$ \\
\hline MS1 & MS1SD03A & 25-Jan-94 & 16:10 & 32.1205 & & & $6.10 E-03$ & $5.90 E-03$ \\
\hline MS1 & MSISDO4A & 25-Jan-94 & 17:10 & 44.0404 & & & $5.50 E-03$ & $6.50 E-03$ \\
\hline MS1 & MS1SD05A & 25-Jan-94 & $17: 40$ & 41.4916 & & & 5.60E-03 & $6.90 E-03$ \\
\hline MS1 & MS1SDOSA & 25-Jan-94 & 18:10 & 35.4793 & & & $6.00 E-03$ & 7.90E-03 \\
\hline MS1 & MS1SD07A & 25-Jan-94 & $19: 10$ & 24.9811 & & & $7.00 E-03$ & $1.10 E-02$ \\
\hline MS1 & MSISDOBA & 25-Jan-94 & $21: 10$ & 15.7091 & & & 8.10E-03 & $1.30 \mathrm{E}-02$ \\
\hline MS1 & MS1SDO9A & 26-Jan-94 & 1:10 & 1.668 & & & $8.10 E-03$ & $1.10 E-02$ \\
\hline MS1 & MS1SD10A & 26-Jan-94 & 13:10 & 6.2729 & $3.20 E-06$ & & $9.60 E-03$ & 1.20E-02 \\
\hline MS1 & MS1SD11A & 25-Jan-94 & $16: 40$ & 33.2194 & & & $6.10 E-03$ & $6.10 E-03$ \\
\hline MS1 & MSISDIIB & 25-Jan-94 & $16: 40$ & 33.2194 & & & $6.00 E-03$ & $6.10 E-03$ \\
\hline MS1 & MS1SD14A & 25-Jar-94 & $20: 10$ & 18.8101 & & & $7.70 \mathrm{E}-03$ & 1.30E-02 \\
\hline MS1 & MS1SD14B & 25-Jan-94 & 20:10 & 18.8101 & & & $7.80 E-03$ & 1.30E-02 \\
\hline MS1 & MS1SD15A & 31-Jan-94 & $11: 15$ & 2.6564 & & & $1.20 E-02$ & $9.80 E-03$ \\
\hline MS1 & MS1SE01A & 1-Mar-94 & $12: 35$ & 5.0124 & & & $1.10 E-02$ & $8.70 E-03$ \\
\hline MS1 & MS1SE02A & 1-Har-94 & 13:35 & 11.0077 & & & 1.10E-02 & $9.20 E-03$ \\
\hline MSI & MS1SE03A & 1-Mar-94 & 14:35 & 24.0408 & & & $9.80 E-03$ & $6.60 E-03$ \\
\hline MS1 & MSISEOAA & 1-Mar-94 & $15: 35$ & 34.3386 & & & $7.20 E-03$ & $4.10 E-03$ \\
\hline
\end{tabular}




\begin{tabular}{|c|c|c|c|c|c|c|c|c|}
\hline Sito & Sample ID's & $\begin{array}{l}\text { Date Sample } \\
\text { Collected }\end{array}$ & $\begin{array}{l}\text { Time Sample } \\
\text { Collected }\end{array}$ & $\begin{array}{c}\text { Discharge Flow } \\
\text { (liters/sec) }\end{array}$ & $\begin{array}{l}\text { Ceslum-137 } \\
\text { Risk }\end{array}$ & $\begin{array}{l}\text { Cobalt-60 } \\
\text { Risk }\end{array}$ & $\begin{array}{c}\text { Strontium-89/90 } \\
\text { Rlsk }\end{array}$ & Tritium Risk \\
\hline MS1 & MS1SE05A & 1-Mar-94 & $16: 35$ & 32.1184 & & & 6.90E-03 & $4.80 E-03$ \\
\hline MS1 & MS1SE05C & 1-Mar-94 & $16: 35$ & 32.1184 & & & $6.90 \mathrm{E}-03$ & $4.90 E-03$ \\
\hline MS1 & MSISEO6A & 1-Mar-94 & $20: 05$ & 21.3383 & & & 7.20E-03 & $9.40 E-03$ \\
\hline MS1 & MS1SE07A & 2-Mar-94 & $1: 05$ & 18.007 & & & $7.70 E-03$ & $7.70 E-03$ \\
\hline MS1 & MS1SE08A & 2-Mar-94 & $5: 35$ & 14.2731 & & & 8.60E-03 & $7.90 E-03$ \\
\hline MS1 & MS1SEOSA & 2-Mar-94 & $8: 05$ & 28.9395 & & & $8.50 E-03$ & $6.90 E-03$ \\
\hline MS1 & MS1SE10A & 2-Mar-94 & 9:05 & 41.4894 & & & $6.40 E-03$ & $3.90 E-03$ \\
\hline MS1 & MS1SEIIA & 2-Mar-94 & $9: 35$ & 62.6531 & & & 5.60E-03 & $3.50 E-03$ \\
\hline MS1 & MS1SE12A & 2-Mar-94 & $10: 05$ & 79.4402 & & & $4.50 E-03$ & $2.70 E-03$ \\
\hline MSI & MS1SE13A & 2-Mar-94 & $11: 05$ & 52.1851 & & & 5.50E-03 & $4.60 E-03$ \\
\hline MSI & MSTSE14A & 2-Mar-94 & $12: 05$ & 44.0379 & & & 5.70E-03 & 2.60E-03 \\
\hline MS1 & MSISE14B & 2-Mar-94 & $12: 05$ & 44.0379 & & & $5.70 E-03$ & 6.10E-03 \\
\hline MS1 & MS1SE15A & 2-Mar-94 & $13: 05$ & 39.0236 & & & $6.10 E-03$ & $5.70 E-03$ \\
\hline MS1 & MS1SE16A & 2-Mar-94 & $15: 05$ & 29.979 & & & $7.00 E-03$ & 5.30E-03 \\
\hline MS1 & MS1SE16CD & 2-Mar-94 & $15: 05$ & 29.979 & & & $7.10 \mathrm{E}-03$ & 5.20E-03 \\
\hline MS1 & MS1SE17A & 2-Mar-94 & $17: 05$ & 25.9408 & & & $7.80 E-03$ & $5.10 E-03$ \\
\hline MS1 & MS1SE18A & 3-Mar-94 & $0: 05$ & 17.2222 & & & $9.00 \mathrm{E}-03$ & $5.60 E-03$ \\
\hline MS1 & MS1SE19A & 3-Mar-94 & $12: 05$ & 16.4565 & & & $1.10 E-02$ & $6.20 E-03$ \\
\hline MS1 & MSISE2OA & 4-Mar-94 & $0: 05$ & 6.2739 & & & 1.20E-02 & $6.60 \mathrm{E}-03$ \\
\hline MS1 & MS1SE21A & 5-Mar-94 & $12: 05$ & 1.8916 & & & $1.20 E-02$ & $7.10 E-03$ \\
\hline MS1 & MS1SE22A & 1-Mar-94 & $17: 05$ & 32.1184 & & & $6.50 E-03$ & 5.60E- 03 \\
\hline MS1 & MS1SF01A & 13-Jul-94 & $21: 45$ & 0.2351 & & & $1.20 E-02$ & 1.10E-02 \\
\hline MS1 & MS1SFO2A & $13-\sqrt{u l}-94$ & $22: 00$ & 0.3172 & $1.60 E-05$ & & 1.20E-02 & 1.10E-02 \\
\hline MS1 & MS1SF03A & 13-Jul-94 & $22: 15$ & 0.3172 & & & $1.20 E-02$ & 1.10E-02 \\
\hline MS1 & MSISFO4A & 13-Jul-94 & $22: 30$ & 0.4106 & & & $1.30 E-02$ & $1.20 E-02$ \\
\hline MS1 & MSISF05A & 13-Jul-94 & $22: 45$ & 0.4106 & & & 1.30E-02 & 1.30E-02 \\
\hline MS1 & MS1SFOSA & 13-Jul-94 & $23: 00$ & 0.4106 & & & $1.30 E-02$ & $1.40 E-02$ \\
\hline MS1 & MS1SF07A & 13-Jul-94 & $23: 15$ & 0.4106 & $2.10 E-06$ & & 1.40E-02 & $1.40 E-02$ \\
\hline MS1 & MS1SFOBA & 13-Jul-94 & $23: 30$ & 0.4106 & & & $1.40 E-02$ & $1.40 E-02$ \\
\hline MS1 & MS1SF09A & 14-Jul-94 & $12: 45$ & 0.1133 & & & $1.40 E-02$ & $1.40 E-02$ \\
\hline MS1 & MSISGO1A & 5-Aug-94 & $4: 10$ & 1.2659 & & & 8.80E-03 & $9.50 E-03$ \\
\hline MS1 & MS1SG02A & 5-Aug-94 & $4: 25$ & 4.2565 & & & $8.60 E-03$ & $9.60 E-03$ \\
\hline MS1 & MS1SG03A & 5-Aug-94 & $4: 55$ & 4.6275 & & & 9.90E-03 & $1.20 E-02$ \\
\hline MS1 & MS1SG04A & 5-Aug-94 & $5: 25$ & 3.5683 & & & $9.40 E-03$ & $1.20 E-02$ \\
\hline MS1 & MSISGO4C & 5-Aug-94 & 5:25 & 3.5683 & & & $9.60 E-03$ & $1.20 E-02$ \\
\hline MSi & MS1SG05A & 5-Aug-94 & $5: 55$ & 2.6564 & & & $1.00 E-02$ & $1.40 E-02$ \\
\hline MS1 & MS1SG06A & 5-Aug-94 & $6: 25$ & 2.1325 & & & $1.10 E-02$ & $1.50 \mathrm{E}-02$ \\
\hline MS1 & MS1SG07A & 5-Aug-94 & $5: 55$ & 2.6564 & & & $3.00 E-02$ & 1.50E-02 \\
\hline MS1 & MSISGOBA & 5-Aug-94 & $9: 25$ & 0.9232 & $2.80 \mathrm{E}-06$ & & 1.30E-02 & $1.80 E-02$ \\
\hline MS1 & MSISGOSA & 5-Aug-94 & $13: 55$ & 0.4106 & & & $1.30 E-02$ & $1.80 E-02$ \\
\hline MS1 & MSISG1OA & 6-Aug-94 & $16: 15$ & 0.3172 & & & 1.30E-02 & 1.60E-02 \\
\hline MS1 & MS1SI01A & $17-5 e p-94$ & $23: 45$ & 41.4916 & & & $4.00 E-03$ & $7.00 E-03$ \\
\hline 575 & MS1SI02A & 18-Sep-94 & $0: 00$ & 42.7547 & $9.90 E-06$ & & $4.00 E-03$ & $5.30 E-03$ \\
\hline$\$ 75$ & S75GS01-G & 21-Feb-93 & & & $1.70 E-06$ & $1.00 E-04$ & & \\
\hline$\$ 75$ & S75GS10-1 & $28-$ May-93 & & & 2.10E-05 & $1.10 E-03$ & & \\
\hline S75 & S75GS11-L & 19-May-93 & & & $2.10 E-05$ & $6.50 E-04$ & & \\
\hline 575 & S75GS11-1D & 19-May-93 & & & 1.90E-05 & $6.00 E-04$ & & \\
\hline$S 75$ & S75SB01-G & 7-Jan-94 & & & $\begin{array}{l}1.20 E-05 \\
3.50 E-05\end{array}$ & $\begin{array}{l}7.90 E-05 \\
6.30 E-05\end{array}$ & $\begin{array}{l}2.00 E-05 \\
6.00 E-06\end{array}$ & \\
\hline$\$ 75$ & S75SB02-G & 7-Jan-94 & & $\therefore$ & 3.50E-06 & $6.30 E-05$ & $\frac{6.00 \mathrm{E}-06}{3.80 \mathrm{E}-05}$ & \\
\hline T2A & $\begin{array}{c}\text { S75SD01-G } \\
\text { T2ABA94 }\end{array}$ & $\begin{array}{l}\text { 25-Jan-94 } \\
\text { 28-Feb-94 }\end{array}$ & $15: 30$ & 1.3764 & $1.20 \mathrm{E}-05$ & $1.60 \mathrm{E}-04$ & $\begin{array}{l}3.80 E-05 \\
8.20 E-03\end{array}$ & $6.20 \mathrm{E}-03$ \\
\hline $\begin{array}{l}T 2 A \\
T 2 A\end{array}$ & $\begin{array}{l}\text { T2ABA94 } \\
\text { T2ABC94 }\end{array}$ & $\begin{array}{l}20 \text {-reb-94 } \\
20 \text {-Apr-94 }\end{array}$ & $14: 00$ & 1.6199 & $6.80 E-06$ & & 8.50E-03 & 4.20E-03 \\
\hline $\begin{array}{l}\text { T2A } \\
\text { T2A }\end{array}$ & T2ABD94 & 27-Apr-94 & $10: 30$ & 0.9459 & $1.30 E-05$ & & $8.40 E-03$ & 4.20E-03 \\
\hline & T2ABE94 & 13-Jun-94 & $8: 30$ & 0 & 8.30E-06 & & $9.80 \mathrm{E}-03$ & 5.00E-03 \\
\hline & T2ABH94 & 2-Sep-94 & $11: 00$ & 0.5976 & & & $1.10 E-02$ & $1.30 \mathrm{E}-02$ \\
\hline & T2AGSOI & 21-Feb-93 & $13: 30$ & 0.7873 & $3.00 E-06$ & & $4.90 E-03$ & 6.10E-03 \\
\hline $\begin{array}{l}\text { T2A } \\
\text { T2A }\end{array}$ & T2AGS10 & 18-May-93 & $13: 45$ & 0.7873 & 8.10E-06 & & $1.00 \mathrm{E}-02$ & $5.60 E-03$ \\
\hline & T2AGSIOD & 18-May-93 & $13: 45$ & 0.7873 & $9.50 E-06$ & & $1.00 E-02$ & $5.50 \mathrm{E}-03$ \\
\hline & T2AGS11 & 19-May-93 & $14: 00$ & 108.4939 & $1.20 E-05$ & & $8.20 E-03$ & $5.00 E-03$ \\
\hline & T2ASB01A & 7-Jan-94 & $11: 30$ & 12.4155 & $2.10 E-06$ & & $6.50 E-03$ & $1.30 E-02$ \\
\hline $\begin{array}{l}\text { T2A } \\
\text { T2A }\end{array}$ & T2ASB02A & 7-Jan-94 & $14: 45$ & 15.508 & & & $6.70 E-03$ & $1.20 E-02$ \\
\hline $\begin{array}{l}\text { T2A } \\
\text { T2A }\end{array}$ & T2ASBO3A & $7-\operatorname{Jan}-94$ & $17: 00$ & 19.8721 & & & $6.50 E-03$ & $1.10 \mathrm{E}-02$ \\
\hline T2A & T2ASBOAA & 7-Jan-94 & $23: 15$ & 10.3255 & $4.70 E-06$ & & $6.70 E-03$ & $1.40 E-02$ \\
\hline & T2ASB05A & 8-Jan-94 & $3: 15$ & 8.4337 & & & $6.80 E-03$ & $1.40 E-02$ \\
\hline $\begin{array}{l}\text { T2A } \\
\text { T2A }\end{array}$ & T2ASCOIA & 11-Jan-94 & $18: 10$ & 3.9308 & 2.20E-06 & & $7.20 E-03$ & $1.20 E-02$ \\
\hline $\begin{array}{l}\text { T2A } \\
\text { T2A }\end{array}$ & T2ASCO2A & $11-\operatorname{Jan}-94$ & $18: 55$ & 5.7178 & & & $7.10 E-03$ & $1.10 E-02$ \\
\hline $\begin{array}{l}\text { T2A } \\
\text { T2A }\end{array}$ & T2ASco3A & $11-J a n-94$ & $21: 40$ & 17.1874 & & & $6.20 E-03$ & 1.10E-02 \\
\hline $\begin{array}{l}\text { T2A } \\
\text { T2A }\end{array}$ & T2ASCOAA & 11-Jan-94 & $21: 55$ & 18.9546 & $4.80 \mathrm{E}-06$ & & 7.30E-03 & $1.10 E-02$ \\
\hline $\begin{array}{l}\text { T2A } \\
\text { T2A }\end{array}$ & T2ASC05A & 12-Jan-94 & $15: 15$ & 11.6962 & $6.80 E-05$ & & $6.50 E-03$ & 8.70E-03 \\
\hline $\begin{array}{l}\mathrm{T} 2 \mathrm{~A} \\
\mathrm{~T} 2 \mathrm{~A}\end{array}$ & T2ASDOIA & 25-Jan-94 & $14: 05$ & 5.2364 & 9.10E-06 & & 7.70E-03 & $9.80 E-03$ \\
\hline $\begin{array}{l}\text { T2A } \\
\text { T2A }\end{array}$ & T2ASD02A & 25-Jan-94 & $15: 35$ & 23.7633 & $3.50 E-06$ & & 7.20E-03 & $9.00 \mathrm{E}-03$ \\
\hline $\begin{array}{l}\text { T2A } \\
\text { T2A }\end{array}$ & T2ASDOBA & 25-Jan-94 & $16: 35$ & 41.5624 & & & 5.40E-03 & $5.80 E-03$ \\
\hline $\begin{array}{l}\text { T2A } \\
\text { T2A }\end{array}$ & T2ASDO4A & 25-Jan-94 & $17: 35$ & 53.1396 & & & 4.90E-03 & $5.40 \mathrm{E}-03$ \\
\hline & T2ASD05A & 25-Jan-94 & 18.05 & 51.6132 & & & $4.80 E-03$ & 5.70E-03 \\
\hline $\begin{array}{l}\text { T2A } \\
\text { T2A }\end{array}$ & T2ASD06A & 25-Jan-94 & $18: 35$ & 45.7311 & $1.20 E-05$ & & $4.60 E-03$ & $5.60 E-03$ \\
\hline $\begin{array}{l}\text { T2A } \\
\text { T2A }\end{array}$ & T2ASD07A & 25-Jan-94 & $19: 35$ & 31.438 & & & $5.20 E-03$ & 7.10E-03 \\
\hline $\begin{array}{l}\text { T2A } \\
\text { T2A }\end{array}$ & T2ASDOBA & 25-Jan-94 & $22: 35$ & 14.7009 & & & 6.60E-03 & $1.00 E-02$ \\
\hline $\begin{array}{l}12 A \\
T 2 A\end{array}$ & T2ASDOSA & 26-Jan-94 & $2: 35$ & 9.6741 & & & $6.90 E-03$ & 9.90E-03 \\
\hline$\frac{T 2 A}{T 2 A}$ & T2ASD10A & 26-Jan-94 & $13: 35$ & 5.7178 & & & $7.30 \mathrm{E}-03$ & 9.50E-03 \\
\hline $\begin{array}{l}\text { T2A } \\
\text { T2A }\end{array}$ & T2ASD11A & 25-Jan-94 & $16: 05$ & 35.0658 & & & 7.10E-03 & $8.00 E-03$ \\
\hline
\end{tabular}




\begin{tabular}{|c|c|c|c|c|c|c|c|c|}
\hline Site & Sump!o ID's & $\begin{array}{l}\text { Date Sample } \\
\text { Collected }\end{array}$ & $\begin{array}{l}\text { Time Samplo } \\
\text { Collected }\end{array}$ & $\begin{array}{l}\text { Discharge Flow } \\
\text { (Itters/sec) }\end{array}$ & $\begin{array}{l}\text { Cesium-137 } \\
\text { Risk }\end{array}$ & $\begin{array}{l}\text { Cobalt } 60 \\
\text { Rlsk }\end{array}$ & $\begin{array}{l}\text { Strontium-89/90 } \\
\text { Risk }\end{array}$ & Tritum Rssk \\
\hline T2A & T2ASD11B & 25-Jan-94 & $16: 05$ & 35.0658 & & & $6.70 E-03$ & $7.80 E-03$ \\
\hline T2A & T2ASD15A & 31-Jan-94 & 11:15 & 1.6199 & & & B.50E-03 & $7.60 E-03$ \\
\hline T2A & T2ASD16A & 28-Jan-94 & $2: 00$ & 42.9303 & $5.90 E-06$ & & $5.90 E-03$ & $6.00 E-03$ \\
\hline T2A & T2ASD16C & 28-Jan-94 & 2:00 & 42.9303 & & & $5.70 E-03$ & $6.00 E-03$ \\
\hline T2A & T2ASD17A & 28-Jan-94 & 4:00 & 45.7311 & & & $5.30 E-03$ & $5.10 E-03$ \\
\hline T2A & T2ASEOIA & 1-Mar-94 & $12: 30$ & 5.7178 & & & $7.40 E-03$ & $5.40 E-03$ \\
\hline T2A & T2ASEO2A & 1+Mar-94 & 13:30 & 13.1546 & & & $6.60 E-03$ & $4.90 E-03$ \\
\hline $12 A$ & T2ASE04A & 1-Mar-94 & 15:30 & 40.2172 & & & $6.20 E-03$ & $4.60 E-03$ \\
\hline T2A & T2ASE04C & 1-Mar-94 & 15:30 & 40.2172 & & & $6.40 E-03$ & 4.60E-03 \\
\hline T2A & T2ASE05A & 1-Mar-94 & 16:00 & 42.9303 & & & $6.00 E-03$ & $3.90 E-03$ \\
\hline T2A & T2ASE06A & 1-Mar-94 & 17:30 & 40.2172 & & & $5.50 E-03$ & $4.00 E-03$ \\
\hline T2A & T2ASEOBA & 2Mar-94 & 3:30 & 20.8124 & & & $5.90 E-03$ & $5.70 E-03$ \\
\hline T2A & T2ASE08C & 2-Mar-94 & 3:30 & 20.8124 & & & $3.70 E-03$ & $5.70 E-03$ \\
\hline T2A & T2ASEO9A & 2-Mar-94 & $6: 30$ & 17.1874 & & & $7.70 E-03$ & 5.60E-03 \\
\hline T2A & T2ASE10A & 2 -Mar-94 & $8: 00$ & 29.1328 & & & $5.80 E-03$ & $5.00 E-03$ \\
\hline T2A & T2ASE11A & 2-Mar-94 & 9:00 & 48.6254 & & & $5.40 E-03$ & $4.20 E-03$ \\
\hline T2A & T2ASE12A & 2-Mar-94 & 10:00 & 92.5498 & & & $4.50 E-03$ & $3.00 E-03$ \\
\hline T2A & T2ASE13A & 2-Mar-94 & 10:30 & 107.4404 & & & $4.10 E-03$ & $2.60 E-03$ \\
\hline $\mathrm{T} 2 \mathrm{~A}$ & T2ASE14A & 2-Mar-94 & 11:00 & 100.9183 & & & 4.10E-03 & $250 E-03$ \\
\hline T2A & T2ASE14C & 2-Mar-94 & $11: 00$ & 100.9183 & & & $4.10 E-03$ & 2.60E-03 \\
\hline T2A & T2ASE15A & 2-Mar-94 & 11:30 & 71.4514 & & & $4.40 \mathrm{E}-03$ & 3.10E-03 \\
\hline T2A & T2ASE16A & 2-Mar-94 & $12: 30$ & 57.8578 & & & $4.50 E-03$ & $4.10 E-03$ \\
\hline T2A & T2ASE17A & 2+Mar-94 & 14:00 & 47.167 & & & 4.80E-03 & 4.20E-03 \\
\hline T2A & T2ASE18A & 2-Mar-94 & 17:00 & 35.3176 & & & 5.30E-03 & $3.80 E-03$ \\
\hline T2A & T2ASE19A & 3-Mar-94 & $0: 00$ & 22.758 & & & $6.10 E-03$ & $4.00 E-03$ \\
\hline T2A & T2ASE20A & 3-Mar-94 & 4:00 & 17.1874 & & & $6.60 E-03$ & $5.40 E-03$ \\
\hline T2A & T2ASE22A & 4-Mar-94 & $12: 00$ & 4.3443 & & & $7.70 E-03$ & 4.80E-03 \\
\hline T2A & T2ASE23A & 5-Mar-94 & 12:00 & 2.4837 & & & $8.60 E-03$ & 4.30E-03 \\
\hline T2A & T2ASEO7A & 1-Mar-94 & 19:00 & 30.2741 & & & $6.00 E-03$ & $5.40 E-03$ \\
\hline T2A & T2ASFO1 & 13-Jut-94 & 21:45 & 0.7618 & $1.30 E-05$ & $6.30 \mathrm{E}-06$ & $9.50 E-03$ & $6.20 \mathrm{E}-03$ \\
\hline T2A & T2ASFO2 & 13-Jul-94 & 22:00 & 0.9459 & 1.30E-05 & $5.00 E-06$ & $9.70 E-03$ & $6.40 E-03$ \\
\hline T2A & T2ASF03 & 13-Jur-94 & 22:15 & 1.1498 & $8.70 E-06$ & $4.90 E-06$ & $9.50 E-03$ & $6.40 E-03$ \\
\hline T2A & T2ASFO4 & 13-Jut-94 & 22:30 & 1.1498 & $1.20 E-05$ & $3.50 E-06$ & $9.10 E-03$ & $6.30 E-03$ \\
\hline T2A & T2ASF05 & 13-Jul-94 & 22:45 & 1.1498 & $7.50 E-06$ & $5.40 E-06$ & $9.30 E-03$ & $6.50 E-03$ \\
\hline T2A & T2ASF06 & 13-Jur-94 & 23:00 & 1.1498 & $5.90 E-06$ & $5.40 E-06$ & $9.20 E-03$ & $6.40 \mathrm{E}-03$ \\
\hline T2A & T2ASF07 & 13-Jut-94 & 23:15 & 1.1498 & $1.20 E-05$ & 5.00E-06 & $9.40 E-03$ & $6.70 E-03$ \\
\hline T2A & T2ASFOB & 13-Jul-94 & 23:30 & 1.1498 & $8.20 E-06$ & $7.40 E-07$ & $9.10 E-03$ & $6.50 E-03$ \\
\hline$T 2 A$ & T2ASFOSA & 14-Jut-94 & 7:15 & 0.9459 & $7.60 E-06$ & & $9.70 E-03$ & $7.00 E-03$ \\
\hline T2A & T2ASF10A & 14-Jut-94 & 9:00 & 1.1498 & $1.40 E-05$ & & $9.60 E-03$ & $7.00 E-03$ \\
\hline T2A & T2ASF11A & 14-Jur94 & 9:20 & 0.9459 & & & $9.70 E-03$ & $7.10 E-03$ \\
\hline I2A & T2ASF12A & 14-Jut-94 & 10:55 & 0.7618 & $1.20 E-05$ & & $9.80 E-03$ & $7.20 E-03$ \\
\hline T2A & T2ASF13A & 14-Jul-94 & 11:00 & 0.5976 & & & $9.60 E-03$ & $7.10 E=-03$ \\
\hline$T 2 A$ & T2ASF14A & 14-Juk-94 & 11:15 & 0.5976 & $1.30 E-0.5$ & & $1.00 E-02$ & $7.20 \mathrm{E}-03$ \\
\hline $\mathrm{T} 2 \mathrm{~A}$ & T2ASG01A & 5-Aug-94 & 4:20 & 2.815 & $1.10 E-05$ & & $6.80 E-03$ & $6.40 E-03$ \\
\hline I2A & T2ASG02A & 5-Aug-94 & $4: 35$ & 4.7804 & $3.20 E-06$ & & $6.70 E-03$ & $6.50 E-03$ \\
\hline T2A & T2ASG03A & 5-Aug-94 & $4: 50$ & 7.8475 & & & $6.70 E-03$ & $6.50 E-03$ \\
\hline T2A & T2ASGOAA & 5-Aug-94 & 5:05 & 9.0426 & & & $6.60 E-03$ & $6.20 E-03$ \\
\hline T2A & T2ASG05A & 5-Aug-94 & $5: 50$ & 6.7402 & & & $7.20 \mathrm{E}-03$ & $8.10 E-03$ \\
\hline T2A & T2ASGO5C & 5-Aug-94 & $5: 50$ & 6.7402 & & & $7.40 E-03$ & $8.20 \mathrm{E}-03$ \\
\hline $12 A$ & T2ASG06A & 5-Aug-94 & 6:05 & 5.7178 & & & $7.40 E-03$ & $8.40 E-03$ \\
\hline $\mathrm{T} 2 \mathrm{~A}$ & T2ASGOTA & 5-Augg-94 & 7:05 & 3.5372 & & & $8.00 E-03$ & $9.10 E-03$ \\
\hline T2A & T2ASGOBA & 5-Aug-94 & 9:35 & 2.175 & & & $9.10 E-03$ & 1.10E-02 \\
\hline T2A & T2ASGOSA & 5-Aug-94 & $14: 05$ & 2.175 & & & $9.70 E-03$ & $1.20 \mathrm{E}-02$ \\
\hline T2A & T2ASG1OA & 6-Aug-94 & $16: 30$ & 0.2266 & & & $1.00 \mathrm{E}-02$ & $1.00 \mathrm{E}-02$ \\
\hline
\end{tabular}


C-8

1

,

$i$
$i$

,

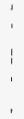

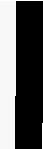

, 


\section{APPENDIX D}

NONCARCINOGENIC HAZARD QUOTIENT TABLES FOR THE TRIBUTARIES DATA USED IN THE WAG 2 ASSESSMENT 


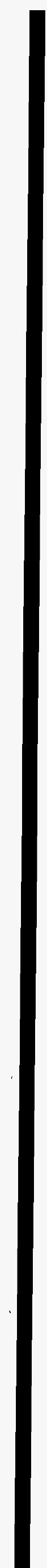




\begin{tabular}{|c|c|c|}
\hline Itte & asmple to's: & $\begin{array}{l}\text { Date semple } \\
\text { Collected }\end{array}$ \\
\hline ESP & ESPBCQ4 & 20-Apr.q4 \\
\hline $\begin{array}{l}\text { ESP } \\
\text { ESP }\end{array}$ & $\begin{array}{l}\text { ESPGSO1 } \\
\text { ESPSD01A }\end{array}$ & 21fob-93 \\
\hline $\begin{array}{l}\text { ESP } \\
\text { ESP }\end{array}$ & $\begin{array}{l}\text { ESPSDO1A } \\
\text { ESPSDO2A }\end{array}$ & $25 \sin -24$ \\
\hline $\begin{array}{l}\text { ESP } \\
\text { ESP }\end{array}$ & $\begin{array}{l}\text { ESPSDO2A } \\
\text { ESPSD03A }\end{array}$ & 25-varn-24 \\
\hline $\begin{array}{l}\text { ESP } \\
\text { ESP }\end{array}$ & $\begin{array}{l}\text { ESPSDO3A } \\
\text { ESPSDO4A }\end{array}$ & 25-Jan-24 \\
\hline ESP & ESPSDOAA & 25-Jen-94 \\
\hline ESP & ESPSDOSA & 25-van-94 \\
\hline $\begin{array}{l}\text { ESP } \\
\text { ESP }\end{array}$ & ESPSDOSA & $25-\sqrt{a}-94$ \\
\hline ESP & ESPSDO7A & 25-van-94 \\
\hline ESP & ESPSOOTALO & $25-\sqrt{2 n-94}$ \\
\hline ESP & ESPSDOSA & 25 - Jan-84 \\
\hline ESP & ESPSDOSA & 26-van-4 \\
\hline ESP & ESPSDIOA & 26-ver-94 \\
\hline ESP & ESPSDI3A & $25 \sqrt{2}$ - 44 \\
\hline ESP & ESPSD13B & 31 ven-84 \\
\hline ESP & ESPSDIAC & 31-Jan-24 \\
\hline ESP & ESPSE01A & 1-Mar-os \\
\hline ESP & ESPSE02A & 1-Mar-os \\
\hline ESP & ESPSEOSA & 1-Mer-os \\
\hline ESP & ESPSE05A & 1-Mar-o4 \\
\hline ESP & ESPSEOSA & 1-Mar-os \\
\hline ESP & ESPSEOTB & $2+$ Mar-94 \\
\hline ESP & ESPSEOTC & 2-Mer-os \\
\hline ESP & ESPSE1QA & 2-Mar-os \\
\hline ESP & ESPSE12-LO & 2 Her-ges \\
\hline ESP & ESPSE128 & 2-Mar-en \\
\hline ESP & ESPSE15B & 2-Mar-gs \\
\hline ESP & ESPSE15C & 2Mer-94 \\
\hline ESP & ESPSE17A & 2-Mar-24 \\
\hline ESP & ESPSG01A & S-Aug-os \\
\hline ESP & ESPSGOHA & 3-Auger \\
\hline ESP & ESPSG07A & 5.Aug-as \\
\hline ESP & ESPSG09A & 5-Aug-gs \\
\hline ESP & ESPSGI1A & C-Aug-as \\
\hline ESP & ESPSO12A & 5-Aug-as \\
\hline ESP & ESPSO12C & 5-mug-e4 \\
\hline GRA & 1STGSO1 & $2 i$ Feb-93 \\
\hline GRA & SNTGSO1 & 21-Feb-93 \\
\hline GRA & MVIGSOI & 21-feb-93 \\
\hline GRA & MV2GSO1 & 21-Feb-93 \\
\hline GRA & AN3GSO1 & 21-Fob-93 \\
\hline GRA & MWTGSOI & $21-\mathrm{Feb}-93$ \\
\hline GRA & MWTOSOSDG & 21-Feb-93 \\
\hline GRA & RAcoso1 & 21-Feb-93 \\
\hline GRA & RACGSOSD & 21-Feb-93 \\
\hline GRA & $\mathbf{S 7 5 6 5 0 1}$ & 23-Feb-e3 \\
\hline GRA & UMBOSO1 & $21+F 0 D-93$ \\
\hline GRA & WicGsol & 21-Feb-83 \\
\hline GRA & WETGSOI & 21-Fob-93 \\
\hline GRA & WSPGSOY & 21 Feb-93 \\
\hline GRA & WSPGSOSD & 21-Feb-93 \\
\hline GRA & WTIGSO1 & 21-Feb-93 \\
\hline HRT & HRTBCP4 & $22-1 p r-24$ \\
\hline HRT & HRTGSOI & 21-Feb-93 \\
\hline HRT & HRTSDOIA & 25-van-4 \\
\hline HRT & HRTSDO2A & 25-Jan-94 \\
\hline HRT & HRTSDO3A & 25-van-es \\
\hline HRT & HRTSDO3AtD & 25-Jen-as \\
\hline HRT & HRTSDOHA & $25-\sqrt{2 n-24}$ \\
\hline HRT & HRTSOOSA & 25-Jan-94 \\
\hline HRT & HRTSDOGA & 25-Jan-24 \\
\hline HRT & HRTSDOTA & 25-Jar-es \\
\hline HRT & HRTSDOSA & 25-Nin-A4 \\
\hline HRT & HRTSDOSA & 26-Jan-24 \\
\hline HRT & HRTSDIOA & 26-Ven-94 \\
\hline HRT & HRTSD13A & $25-\sqrt{2 n-94}$ \\
\hline HRT & HRTSDI3B & 25-Jan-84 \\
\hline HRT & HRTSD14A & 25-Jan-24 \\
\hline HRT & HRTSDIAB & 25-Jant-84 \\
\hline HRT & HRTSDISC & 3i-Jan-94 \\
\hline HRT & HRTSEO2-L & 1thersos \\
\hline HRT & HRTSE02A & 1+Mur-94 \\
\hline HRT & HRTSEO3A & Sthar-94 \\
\hline HRT & HRTSEO3LD & 1+Mar-se \\
\hline HRT & HRTSEOSA & 9-Mar-94 \\
\hline HRT & HRTSE05A & itmar-os \\
\hline HRT & HRTSEIDA & 2+Mar-94 \\
\hline HRT & HRTSE12A & 2Har-s \\
\hline HRT & HRTSEIA & 2-Mar-os \\
\hline HRT & HRTSEIQA & 2-Mar-94 \\
\hline HRT & HRTSETEC & $2+$ ar-84 \\
\hline HRT & HRTSE2OA & $2-M a r-94$ \\
\hline HRT & HRTSE22A & 3-Mar-94 \\
\hline MSI & MS1BC24 & $20-1 p x-94$ \\
\hline MSi & MSIGSO1 & 21-Feb-93 \\
\hline MS1 & MSISDOIA & 25-Jan-44 \\
\hline MS1 & MS1SDO2A & 25-Jan-24 \\
\hline MSi & MSISDO3C & 25-Janges \\
\hline MSi & MS1SD03CLD & 25 Jan-94 \\
\hline MSi & MSISDOMA & 25-van-4 \\
\hline MSi & MS1SDOSA & 25-Jan-44 \\
\hline MSi & MSISDOSA & 25-Jan-94 \\
\hline MSi & MS1SD07A & 25-Jan-94 \\
\hline MSI & MSISDOEA & 25-Jan-94 \\
\hline MSi & MSISDOSA & 26) Nan-94 \\
\hline
\end{tabular}




\begin{tabular}{|c|c|c|c|c|c|c|c|c|c|c|}
\hline stto & Sample tD's & $\begin{array}{l}\text { Date Semplo } \\
\text { Collected }\end{array}$ & $\begin{array}{c}\text { Time Semple } \\
\text { Coliected }\end{array}$ & $\begin{array}{l}\text { Discherge Flow } \\
\text { (ititerdeac) }\end{array}$ & $\begin{array}{l}\text { Boron Total } \\
\text { Herard Index }\end{array}$ & $\begin{array}{l}\text { Mercury Total } \\
\text { Hezard Index }\end{array}$ & $\begin{array}{l}\text { Zine Total } \\
\text { Huzard Index }\end{array}$ & $\begin{array}{l}\text { Bertum Total } \\
\text { Heard Index }\end{array}$ & $\begin{array}{l}\text { Strontium Total } \\
\text { Hizard Indax }\end{array}$ & $\begin{array}{l}\text { Manganese Total } \\
\text { Hazard indax }\end{array}$ \\
\hline MS1 & MSISDIOA & 26-van-94 & $13: 10$ & 6.2729 & A.20E-02 & 1 & $1.20 \mathrm{E}-03$ & $3.70 E-02$ & $5.00 E-03$ & $3.80 \mathrm{E}-03$ \\
\hline MS1 & MS1SD13A & 25Jan- 94 & $19: 40$ & 21.3391 & $1.60 E-02$ & 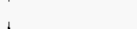 & $1.70 E-03$ & $3.20 E-02$ & $4.80 E-03$ & $1.00 E-02$ \\
\hline MSi & MS1SD13B & 25 Jan-94 & $19: 40$ & 21.3391 & $1.70 E-02$ & ; & $1.00 E-03$ & $3.30 E-02$ & $5.10 E-03$ & $1.10 E-02$ \\
\hline MSi & MSISDISC & 31-Jan-24 & 11:15 & 2.6584 & $2.30 E-02$ & 1 & $1.50 E-03$ & 4.50E-02 & C.70E-03 & $6.20 \mathrm{E}-03$ \\
\hline MS1 & MS1SE01B & 1+Mar-g4 & $12: 35$ & 5.0124 & $2.70 E-02$ & & $1.70 E-03$ & 4.80E-02 & $6.20 E-03$ & $4.00 E-02$ \\
\hline MS1 & MSISEOIB-LD & $1+$ Har-84 & $12: 35$ & 5.0124 & $200=-02$ & & $1.00 E-03$ & 4.00E-02 & 6.30E-03 & $4.00 E-02$ \\
\hline MS1 & MSISEOIC & 1-Mar-94 & $12: 35$ & 5.0124 & $2.70 \equiv-02$ & 1 & $1.80 E-03$ & 5.10E- 02 & B. BOE-03 & $4.40 E-02$ \\
\hline MS1 & MSISEO2A & 1-Mar-24 & $13: 35$ & 11.0077 & $2.80 E-02$ & & $1.00 E-03$ & $5.00 E-02$ & $6.30 E-03$ & 4.80E-02 \\
\hline MS1 & MSISE03A & 1-Mar-94 & 14:35 & 24.0408 & 2.40E-02 & & $260 E-03$ & 4.80E-02 & $5.60 E-03$ & $0.30 E-02$ \\
\hline MSI & MSISEOAA & 1+mar-as & 15:35 & 34,3386 & $1.70 E-02$ & $i$ & $1.80 E-03$ & $3.60 E-02$ & 4.50E-03 & $3.50 E-02$ \\
\hline MS1 & MSISE0\&A & $2+M a x-O 4$ & 8:05 & 28.0395 & $2.00 E-02$ & , & 1.60E-03 & $3.60 E-02$ & $5.30 E-03$ & 2.00E-03 \\
\hline MS1 & MS1SE15A & 2-Mar-os & 13:05 & 39.0238 & 1.80E-02 & & $1.20 E-03$ & $2.90 E-02$ & 4.30E-03 & $9.20 E-03$ \\
\hline MS1 & MS1SE17A & 2Har-os & 17:05 & 25.8408 & $2.00 E-02$ & & $1.80 E-03$ & $3.30 E-02$ & 4.00E-03 & 7.10E-03 \\
\hline MS1 & MS1SE19A & 3-Mar-D4 & 12:05 & 16.4585 & $2.30 E-02$ & & $1.60 E-03$ & $3.90 E-01$ & $5.60 E-03$ & $7.50 E-03$ \\
\hline MS1 & MSISGO1A & 5-Aug-as & $4: 10$ & 1.2859 & $3.60 E-02$ & & $6.70 E-03$ & 1.30E-01 & $6.80 E-03$ & $7.80 E-01$ \\
\hline MS1 & MS1SGO3A & 5-Aug-24 & $4: 55$ & 4.6275 & 4.40E-02 & $\vdots$ & $5.30 E-03$ & 7.30E-02 & 7.40E-03 & 2.30E-01 \\
\hline MS1 & MS1SG05A & 5-Aus-24 & 5:55 & 26584 & $4.50 E=-02$ & 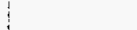 & $1.20 E-03$ & $0.00 E-02$ & $7.70 E-03$ & $9.30 \mathrm{E}-02$ \\
\hline MSi & MSISGOBA & 5-Aug-a4 & $9: 25$ & 0.9232 & $5.00 E-02$ & & 5.00E-04 & 6.60E-02 & $9.70 E-03$ & 6.10E-02 \\
\hline MSI & MSISG10A & 6-Aug-24 & 18:15 & 0.3172 & $5.40 E-02$ & $i$ & $5.00 E-04$ & 7.00E-02 & $9.60 E-03$ & $1.80 E-01$ \\
\hline MS1 & MSISGIIA & 5-Aug-gS & $4: 40$ & 4.2565 & $4.20 E-02$ & . & $2.70 E-03$ & $7.70 E-02$ & 7.50E-03 & 2.40E-01 \\
\hline MSI & MSISGIIC & 5-Aug-es & $4: 40$ & 4.2585 & $4.00 E-02$ & : & 2.60E-03 & $7.60 E-02$ & $7.30 E-03$ & 2.80E-01 \\
\hline T2A & T2ABC94A & $20-A p r-94$ & $14: 00$ & 1.6189 & & 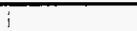 & 6.30E-04 & $3.70 E-02$ & $7.00 \mathrm{E}-03$ & 6.80E-03 \\
\hline IZA & T2ABCSAB & 20-Apr-94 & 14:00 & 1.6109 & & 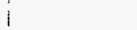 & Q.00E-04 & $3.60 E-02$ & $7.00 E-03$ & 6. $.00 E-03$ \\
\hline T2A & T2AGSOT & 21-Feb-83 & 13:30 & 0.7873 & $270 E-02$ & i & $1.30 E=-03$ & $2.80 E-02$ & 4.80E-03 & $3.80 E-02$ \\
\hline T2A & T2AGSOSD & 21-feb-93 & 13:30 & 0.7873 & & 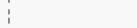 & $3.30 \mathrm{E}-0 \mathrm{~s}$ & & & \\
\hline T2A & TZASDOTA & 25-van-94 & 14:05 & 5.2384 & $3.50 E-02$ & $\vdots$ & $1.70 E-03$ & $2.90 E-02$ & 6.70E-03 & 2.60E-02 \\
\hline T2A & T2ASDOZA & 25-Jan-24 & $15: 35$ & 23.7633 & $2.40 E-02$ & : & 2.80E-03 & $3.40 E-02$ & $0.50 E-03$ & 4.40E-02 \\
\hline T2A & T2ASD03A & 25-van-get & 16:35 & 41.5624 & $1.80 E-02$ & 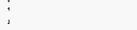 & $2.60 E-03$ & $2.00 E-02$ & $5.20 E-03$ & 4.50E.02 \\
\hline $12 A$ & TZASDOSA & 25-Van-84 & $17: 35$ & 53.1398 & 2.10E-02 & . & $2.20 E-03$ & $270 E-02$ & $5.00 E-03$ & $2.00 E-02$ \\
\hline T2A & T2ASD05A & 25Jan-04 & 18:05 & 51.6132 & $1.80 E-02$ & & $1.00 E-03$ & 2.40E-02 & $4.80 E-03$ & $1.90 E-02$ \\
\hline TZA & T2ASDOEA & 25-لven-94 & 18:35 & 45.7311 & $2.30 \mathrm{E}-02$ & & $1.00 E-03$ & 260E-02 & 4.00E-03 & 1.40E-02 \\
\hline T2A & TZASDOTA & 25-Jan-94 & 19:35 & 31.438 & $3.60 E-02$ & & $1.80 E-03$ & 2.40E-02 & $5.20 E-03$ & $8.50 E-03$ \\
\hline T2A & T2ASDOSA & 25 Jang4 & $22: 35$ & 14.7009 & $2.70 E-02$ & i & $1.30 E-03$ & $2.50 E-02$ & $5.80 E-03$ & 4.00E-03 \\
\hline T2A & T2ASDOSA & 26-Jan-94 & $2: 35$ & 9.6741 & $2.50 E-02$ & & $1.50 E-03$ & $2.60 E-02$ & $5.00 E-03$ & 3.50E-03 \\
\hline T2A & T2ASDIOA & 20-Jan-84 & 13:35 & 5.7178 & 2.60E-02 & & $1.30 E=03$ & $2.00 E-02$ & $0.20 E-03$ & 2.60E-03 \\
\hline T2A & T2ASD13A & 25-Jan-94 & 19:05 & 37.5948 & $2.40 E-02$ & & $5.00 E-03$ & $8.30 E-02$ & $1.00 E-03$ & 4.50E-01 \\
\hline T2A & T2ASD13B & 25-Jan-24 & $19: 05$ & 37.5948 & $200 E-02$ & & $5.90 E-03$ & 4.40E-02 & $5.10 E-03$ & 4.50E-01 \\
\hline T2A & T2ASDISA & $3 t$ Jan-94 & 11:15 & 1.6199 & 2.90E-02 & & $1.30 E-03$ & $2.80 \equiv-02$ & 6.00E-03 & 5.00E-03 \\
\hline T2A & T2ASE02A & 1+Mar-94 & 13:30 & 13.1546 & $2.20 E-02$ & & $1.80 E-03$ & $3.80 E-02$ & $5.80 E-03$ & 3.00E-02 \\
\hline T2A & T2ASEO3 & 1-Mar-94 & $14: 30$ & 23.76 & $2.30 E-02$ & & 1.10E-02 & $3.70 E-02$ & B. $00 E-03$ & 5.60E-02 \\
\hline T2A & T2ASE05A & $1+$ Mar-94 & 18:00 & 42.9303 & $2.00 E-02$ & & $1.70 E-03$ & $3.10 E-02$ & $5.20 E-03$ & $3.10 E-02$ \\
\hline T2A & T2ASEOTE & 1-Mar-24 & $19: 00$ & 30.2741 & $2.00 E-02$ & & $1.00 E-03$ & $2.00 E-02$ & $5.20 E-03$ & $1.70 E-02$ \\
\hline T2A & TZASEOTC & 1+Mar-s4 & 19:00 & 30.2741 & $2.40 E-02$ & & $1.40 E-03$ & 2.00E-02 & 5.30E-03 & $1.70 E-02$ \\
\hline T2A & T2ASE1OA & 2Har-s4 & $8: 00$ & 29.1328 & $220 E-02$ & & $1.70 E-03$ & $2.80 E-02$ & $5.10 E-03$ & $1.00 E-02$ \\
\hline T2A & T2ASE12A & 2-Mar-ge & $10: 00$ & 92.5488 & $1.80 E-02$ & - & 2.40E-03 & $3.10 E-02$ & $4.30 \mathrm{E}-03$ & 4.60E-02 \\
\hline T2A & T2ASE13A & 2-Har-g4 & $10: 30$ & 107.4404 & $1.90 \mathrm{E}-02$ & & 1.70E-03 & $2.50 E-02$ & $4.00 E-03$ & $2.50 E-02$ \\
\hline T2A & TZASEISA & $2+$ Mar-94 & $11: 30$ & 71.4514 & $1.70 E-02$ & & $1.50 E-03$ & 2.40E-02 & $4.10 E-03$ & $1,40 E-02$ \\
\hline T2A & T2ASE17A & 2-Mar-84 & $14: 00$ & 47.167 & 2.30E-02 & & $1.50 E-03$ & $270 E-02$ & 4.60E-03 & $2.00 E-02$ \\
\hline T2A & TRASEI\&A & 2+Mar-94 & $17: 00$ & 38.3178 & $2.00 E-02$ & & $2.00 E-03$ & $2.70 E-02$ & 4.00E-03 & $1.40 E-02$ \\
\hline T2A & T2ASE19A & 3-Mar-84 & $0: 00$ & 22.758 & $2.10 E-02$ & & $1.00 E-03$ & $3.20 E-02$ & $5.40 E-03$ & 3.20E-02 \\
\hline T2A & T2ASGOIA & 5-Aug-94 & 4:20 & 2.815 & $9.80 E-03$ & & 2.50E-03 & 2.80E-02 & $5.30 \equiv-03$ & $3.80 E-01$ \\
\hline T2A & T2ASGOKA & 5-Aug-as & 5:05 & 0.0426 & $4.10 \equiv-02$ & & $3,40 E-03$ & $5.10 E-02$ & $0.00 E-03$ & 1.80E-01 \\
\hline T2A & T2ASGOSA & 5-Augg-24 & $0: 35$ & 2.175 & $4.80 E-02$ & & 9.00E-04 & 4.50E-02 & 8.00E-03 & $3.00 E-02$ \\
\hline T2A & T2ASGOBA & 5-Augars & $14: 05$ & 2.175 & $5.40 E-02$ & & $9.90 E-04$ & $4.70 E-02$ & 9.60E-03 & 2.00E-02 \\
\hline T2A & TZASGIOA & C-Aug-s4 & $18: 30$ & 0.2288 & $5.50 E-02$ & & 4.70E-04 & 4.40E-02 & $1.00 E-02$ & 4.20E-02 \\
\hline T2A & T2ASG11A & 5-nug-g4 & $5: 20$ & 0.0428 & $3.80 E-02$ & & $2.80 E-03$ & $4.80 E-02$ & $6.80 E-03$ & 1.30E-01 \\
\hline T2A & T2ASG11C & 5-Aupges & $5: 20$ & 9.0428 & 9.80E-03 & & 6.10E-04 & 8.10E-03 & $5.40 E-03$ & $4.10 E-02$ \\
\hline
\end{tabular}




\section{APPENDIX E}

CARCINOGENIC RISK TABLES FOR THE SEEPS TASK DATA USED IN THE WAG 2 ASSESSMENT 



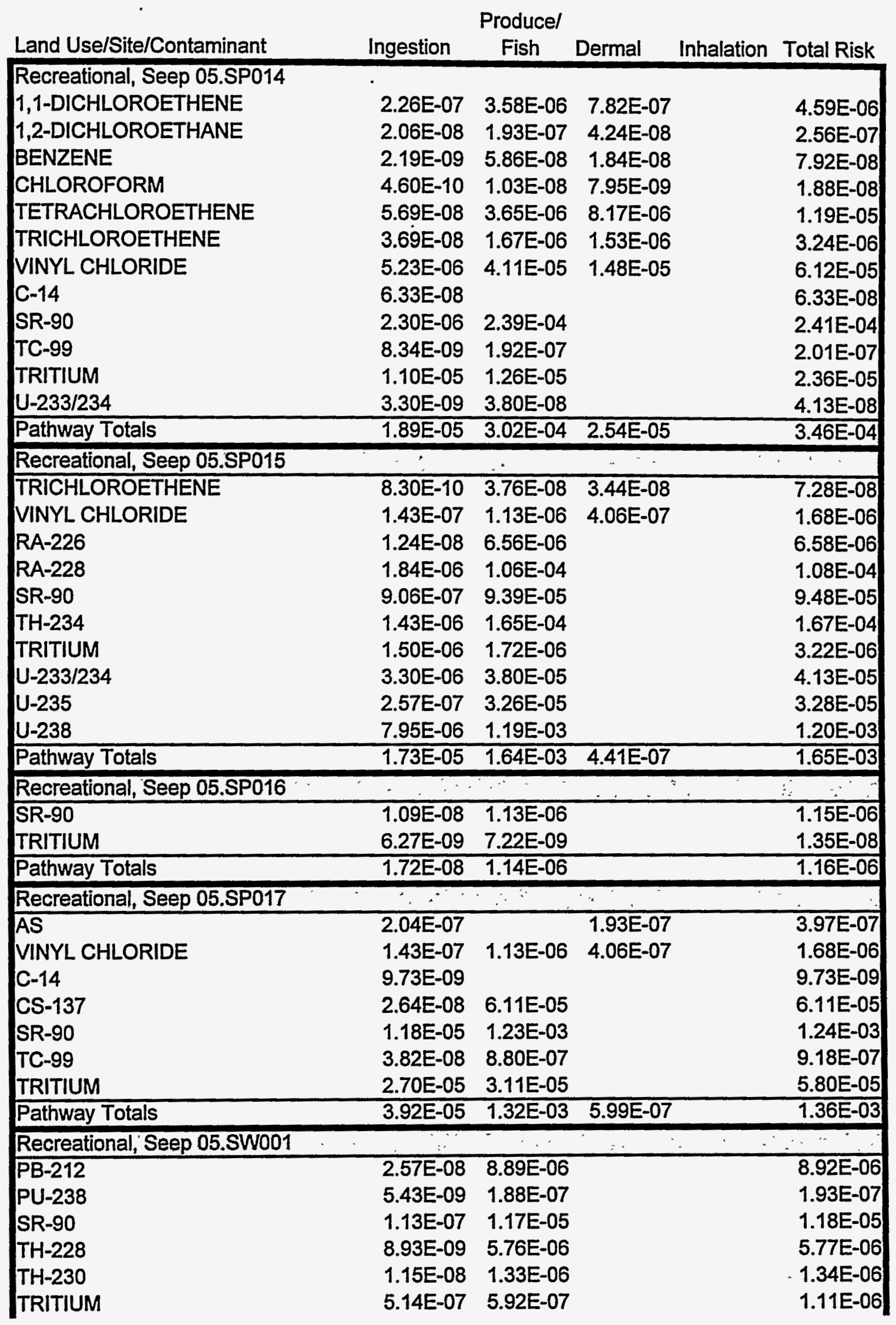




\begin{tabular}{|c|c|c|c|c|}
\hline & & Producel & & \\
\hline Land Use/Site/Contaminant & Ingestion & Fish & Inhalation & Total Risk \\
\hline $\mathrm{U}-233 / 234$ & $1.43 E-07$ & $1.64 \mathrm{E}-06$ & & 1.79E-06 \\
\hline$U-235$ & 5.39E-09 & 6.83E-07 & & 6.89E-07 \\
\hline $\mathrm{U}-235 / 236$ & 7.81E-09 & $9.00 E-08$ & & $9.78 E-08$ \\
\hline U-238 & 3.17E-07 & $4.75 \mathrm{E}-05$ & & $4.78 E-05$ \\
\hline Pathway Totals & $1.15 E-06$ & $7.83 E-05$ & & 7.95E-05 \\
\hline Recreational, Seep 05.SW002 & $\therefore \therefore \quad \therefore$ & $\because$ & & \\
\hline AS & $6.96 \mathrm{E}-08$ & & $6.59 \mathrm{E}-08$ & 1.35E-07 \\
\hline BIS(2-ETHYLHEXYL) PHTHALATE & 3.17E-09 & $1.14 E-05$ & 1.52E-07 & 1.15E-05 \\
\hline AM-241 & 2.06E-07 & $7.12 E-06$ & & 7.32E-06 \\
\hline $\mathrm{C}-14$ & $2.08 E-08$ & & & 2.08E-08 \\
\hline PU-238 & $3.80 E-07$ & 1.31E-05 & & 1.35E-05 \\
\hline PU-239/240 & 4.24E-09 & 1.47E-07 & & 1.51E-07 \\
\hline RA-226 & 4.81E-09 & $2.55 E-06$ & & 2.55E-06 \\
\hline RA-228 & $2.70 E-05$ & 1.56E-03 & & $1.58 \mathrm{E}-03$ \\
\hline SR-90 & 9.39E-06 & 9.74E-04 & & 9.83E-04 \\
\hline TC-99 & $3.58 \mathrm{E}-09$ & $8.25 E-08$ & & 8.61E-08 \\
\hline TH-228 & 1.85E-08 & 1.19E-05 & & 1.20E-05 \\
\hline TH-230 & 2.21E-08 & 2.54E-06 & & 2.57E-06 \\
\hline TRITIUM & $5.21 E-05$ & $6.00 E-05$ & & 1.12E-04 \\
\hline U-233/234 & 1.77E-08 & 2.04E-07 & & 2.21E-07 \\
\hline U-238 & 3.65E-09 & 5.46E-07 & & $5.50 \mathrm{E}-07$ \\
\hline Pathway Totals & $8.93 \mathrm{E}-05$ & 2.64E-03 & $2.17 \mathrm{E}-07$ & $2.73 \mathrm{E}-03$ \\
\hline Recreational, Seep 05.SW003 & $\because \cdots$ & $\therefore \ldots$ & $\because$ & \\
\hline RA-226 & $4.32 E-09$ & 2.29E-06 & & $2.30 \mathrm{E}-06$ \\
\hline SR-90 & 1.81E-07 & 1.87E-05 & & 1.89E-05 \\
\hline TH-228 & 8.03E-09 & 5.18E-06 & & 5.19E-06 \\
\hline TRITIUM & $1.29 E-08$ & 1.49E-08 & & $2.78 E-08$ \\
\hline Pathway Totals & $2.06 \mathrm{E}-07$ & $2.62 E-05$ & & $2.64 \mathrm{E}-05$ \\
\hline Recreational, Seep 05:SW004: & & 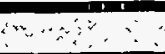 & 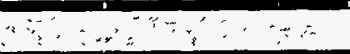 & \\
\hline AM-241 & $1.14 \mathrm{E}-07$ & $3.94 E-06$ & & $4.05 E-06$ \\
\hline $\mathrm{CA}-45$ & $1.35 E-07$ & & & 1.35E-07 \\
\hline CM-243/244 & 8.86E-09 & $3.06 E-07$ & & 3.15E-07 \\
\hline SR-90 & 5.27E-06 & 5.47E-04 & & 5.52E-04 \\
\hline TH-228 & 2.60E-08 & 1.68E-05 & & 1.68E-05 \\
\hline TH-230 & $2.26 E-08$ & 2.61E-06 & & 2.63E-06 \\
\hline TH-232 & 6.89E-09 & 7.93E-07 & & 8.00E-07 \\
\hline TRITIUM & 3.84E-09 & 4.42E-09 & & 8.25E-09 \\
\hline Pathway Totals & $5.59 \mathrm{E}-06$ & 5.71E-04 & & 5.77E-04 \\
\hline Rècreational, Seep 05:SW005 & 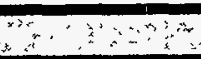 & 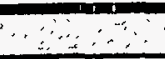 & 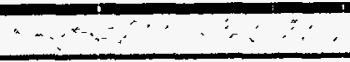 & \\
\hline BIS(2-ETHYLHEXYL) PHTHALATE & 1.90E-08 & $6.83 \mathrm{E}-05$ & $9.09 E-07$ & 6.93E-05 \\
\hline RA-228 & 8.55E-08 & 4.93E-06 & & 5.01E-06 \\
\hline SR-90 & 1.30E-07 & 1.35E-05 & & 1.36E-05 \\
\hline TH-228 & 1.61E-08 & 1.04E-05 & & 1.04E-05 \\
\hline $\mathrm{TH}-230$ & 2.09E-08 & 2.40E-06 & & 2.42E-06 \\
\hline TH-232 & 3.84E-09 & 4.43E-07 & & 4.47E-07 \\
\hline TRITIUM & $1.08 E-07$ & $1.24 E-07$ & & 2.32E-07 \\
\hline U-238 & 3.90E-09 & 5.84E-07 & & 5.88E-07 \\
\hline
\end{tabular}




\begin{tabular}{|c|c|c|c|c|c|}
\hline & & Producel & & & \\
\hline Land Use/Site/Contaminant & Ingestion & Fish & Dermal & Inhalation & Total Risk \\
\hline Pathway Totals & 3.87E-07 & 1.01E-04 & $9.09 \mathrm{E}-07$ & & $1.02 E-04$ \\
\hline \multicolumn{6}{|l|}{ Recreational, Seep 05.SW006 } \\
\hline AM-241 & 1.26E-07 & $4.36 \mathrm{E}-06$ & & & 4.49E-06 \\
\hline C-14 & 7.00E-08 & & & & 7.00E-08 \\
\hline CA-45 & 2.32E-08 & & & & $2.32 E-08$ \\
\hline CM-243/244 & 4.14E-09 & 1.43E-07 & & & 1.47E-07 \\
\hline PU-238 & 8.32E-08 & 2.88E-06 & & & 2.96E-06 \\
\hline SR-90 & 2.39E-06 & $2.48 \mathrm{E}-04$ & & & $2.50 E-04$ \\
\hline TH-228 & 1.89E-08 & 1.22E-05 & & & 1.22E-05 \\
\hline TH-230 & 8.20E-09 & $9.45 \mathrm{E}-07$ & & & 9.53E-07 \\
\hline TRITIUM & 6.36E-06 & 7.33E-06 & & & 1.37E-05 \\
\hline U-238 & 4.76E-09 & 7.13E-07 & & & 7.18E-07 \\
\hline Pathway Totals & $9.09 \mathrm{E}-06$ & $2.76 E-04$ & & & $2.85 E-04$ \\
\hline \multicolumn{6}{|l|}{ Recreational; Seep.5NNT } \\
\hline$\overline{B E}$ & $6.49 E-08$ & $7.48 \mathrm{E}-06$ & $2.52 \mathrm{E}-06$ & & $1.01 \mathrm{E}-05$ \\
\hline METHYLENE CHLORIDE & $3.68 E-09$ & 2.43E-08 & 6.76E-09 & & 3.47E-08 \\
\hline SR-90 & 6.79E-08 & 7.04E-06 & & & 7.11E-06 \\
\hline TRITIUM & 9.65E-09 & 1.11E-08 & & & 2.08E-08 \\
\hline Pathway Totals & 1.46E-07 & $1.46 \mathrm{E}-05$ & 2.53E-06 & & 1.72E-05 \\
\hline \multicolumn{6}{|l|}{ Recreational, Seep 5NST } \\
\hline$\overline{\mathrm{BE}}$ & $9.74 \mathrm{E}-08$ & $1.12 E-05$ & $3.78 E-06$ & & 1.51E-05 \\
\hline SR-90 & 2.91E-07 & $3.01 E-05$ & & & 3.04E-05 \\
\hline TRITIUM & 3.72E-07 & $4.28 \mathrm{E}-07$ & & & 8.00E-07 \\
\hline Pathway Totals & $7.60 \mathrm{E}-07$ & 4.18E-05 & 3.78E-06 & & 4.63E-05 \\
\hline \multicolumn{6}{|l|}{ Recreational, Seep 5NW-1 } \\
\hline$\overline{B E}$ & 8.11E-08 & $9.35 \mathrm{E}-06$ & 3.15E-06 & & $1.26 \mathrm{E}-05$ \\
\hline SR-90 & 6.79E-08 & 7.04E-06 & & & 7.11E-06 \\
\hline TRITIUM & $1.93 E-08$ & 2.22E-08 & & & 4.15E-08 \\
\hline Pathway Totals & $1.68 \mathrm{E}-07$ & 1.64E-05 & $3.15 \mathrm{E}-06$ & & 1.97E-05 \\
\hline \multicolumn{6}{|l|}{ Recreational, Seep 5NW-2 } \\
\hline BE. & $8.11 E-08$ & 9.35E-06 & 3.15E-06 & & $1.26 \mathrm{E}-05$ \\
\hline CS-137 & 5.39E-08 & 1.24E-04 & & & 1.24E-04 \\
\hline SR-90 & 5.28E-08 & 5.48E-06 & & & 5.53E-06 \\
\hline TH-232 & $6.44 E-08$ & 7.42E-06 & & & 7.49E-06 \\
\hline TRITIUM & $9.17 \mathrm{E}-08$ & 1.06E-07 & & & 1.97E-07 \\
\hline$U-238$ & 4.06E-09 & $6.08 \mathrm{E}-07$ & & & 6.12E-07 \\
\hline Pathway Totals & $3.48 \mathrm{E}-07$ & 1.47E-04 & $3.15 \mathrm{E}-06$ & & $1.51 \mathrm{E}-04$ \\
\hline \multicolumn{6}{|l|}{ Recreational, Seep BTT } \\
\hline$\overline{\mathrm{BE}}$ & 9.86E-08 & 1.14E-05 & 3.82E-06 & & $1.53 E-05$ \\
\hline PU-239 & 7.47E-09 & 2.58E-07 & & & 2.65E-07 \\
\hline TH-228 & 4.99E-08 & 3.22E-05 & & & 3.22E-05 \\
\hline$U-232$ & 1.69E-08 & 1.94E-07 & & & 2.11E-07 \\
\hline$U-234$ & $6.50 E-07$ & 7.49E-06 & & & 8.14E-06 \\
\hline U-235 & 2.21E-08 & 2.81E-06 & - & & 2.83E-06 \\
\hline$U-238$ & 4.69E-07 & 7.02E-05 & & & 7.07E-05 \\
\hline CS-137 & 1.29E-06 & 2.98E-03 & & & 2.98E-03 \\
\hline
\end{tabular}




\begin{tabular}{|c|c|c|c|c|}
\hline Land Use/Site/Contaminant & Ingestion & $\begin{array}{l}\text { Produce/ } \\
\text { Fish }\end{array}$ & Inhalation & Total Risk \\
\hline SR-90 & 8.92E-05 & $9.25 E-03$ & & 9.34E-03 \\
\hline TRITIUM & $1.71 E-07$ & 1.98E-07 & & 3.69E-07 \\
\hline Pathway Totals & $9.20 \mathrm{E}-05$ & $1.23 E-02$ & 3.82E-06 & $1.24 E-02$ \\
\hline \multicolumn{5}{|c|}{ Recreational, Seep EAST SEEP } \\
\hline$\overline{A S}$ & 1.96E-07 & & $1.86 \mathrm{E}-07$ & 3.82E-07 \\
\hline BE & 8.11E-08 & 9.35E-06 & 3.15E-06 & 1.26E-05 \\
\hline CO-60 & 2.30E-07 & 7.95E-05 & & 7.98E-05 \\
\hline SR-90 & $1.48 E-07$ & $1.54 E-05$ & & $1.55 \mathrm{E}-05$ \\
\hline TRITIUM & 1.45E-07 & 1.67E-07 & & 3.11E-07 \\
\hline Pathway Totals & 8.01E-07 & $1.04 \mathrm{E}-04$ & 3.33E-06 & $1.09 E-04$ \\
\hline \multicolumn{5}{|l|}{ Recreational; Seèp FG-1 } \\
\hline SR-90 & 1.54E-06 & $1.60 \mathrm{E}-04$ & & $1.62 \mathrm{E}-04$ \\
\hline Pathway Totals & $1.54 \mathrm{E}-06$ & $1.60 \mathrm{E}-04$ & & $1.62 E-04$ \\
\hline \multicolumn{5}{|c|}{ Recreational, Seep FIFTH CREEK } \\
\hline $\mathrm{CS}-137$ & 4.91E-09 & $1.13 \mathrm{E}-05$ & & 1.13E-05 \\
\hline SR-90 & 3.66E-07 & 3.79E-05 & & 3.83E-05 \\
\hline TRITIUM & $3.38 \mathrm{E}-08$ & $3.89 E-08$ & & 7.27E-08 \\
\hline Pathway Totals & 4.05E-07 & 4.93E-05 & & 4.97E-05 \\
\hline \multicolumn{5}{|c|}{ Recreational, Seep FIRST CREEK } \\
\hline $\mathrm{BE}$ & $2.11 \mathrm{E}-08$ & $2.43 E-06$ & $8.19 E-07$ & 3.27E-06 \\
\hline CHLOROFORM & $9.21 \mathrm{E}-11$ & 2.07E-09 & 1.59E-09 & $3.75 E-09$ \\
\hline SR-90 & 1.41E-06 & $1.47 E-04$ & & $1.48 E-04$ \\
\hline TRITIUM & 9.18E-09 & $1.06 E-08$ & & $1.98 \mathrm{E}-08$ \\
\hline Pathway Totals & 1.44E-06 & $1.49 E-04$ & $8.20 \mathrm{E}-07$ & 1.51E-04 \\
\hline \multicolumn{5}{|c|}{ Recreational; Seep FRENCH DR S } \\
\hline 1,1-DICHLOROETHENE & $4.53 \mathrm{E}-09$ & 7.17E-08 & $1.56 \mathrm{E}-08$ & $9.19 \mathrm{E}-08$ \\
\hline 1,2-DICHLOROETHANE & 2.06E-09 & $1.93 E-08$ & 4.24E-09 & 2.56E-08 \\
\hline CHLOROFORM & $9.21 \mathrm{E}-11$ & 2.07E-09 & 1.59E-09 & 3.75E-09 \\
\hline TETRACHLOROETHENE & 1.94E-07 & 1.25E-05 & 2.79E-05 & 4.06E-05 \\
\hline TRICHLOROETHENE & 4.15E-07 & $1.88 E-05$ & $1.72 E-05$ & 3.64E-05 \\
\hline VINYL CHLORIDE & 1.43E-07 & 1.13E-06 & 4.06E-07 & 1.68E-06 \\
\hline Pathway Totals & $7.60 \mathrm{E}-07$ & $3.25 E-05$ & $4.55 \mathrm{E}-05$ & 7.87E-05 \\
\hline \multicolumn{5}{|c|}{ Recreational, Seep FRENCHERAIN } \\
\hline SR-90 & 2.26E-08 & 2.35E-06 & & 2.37E-06 \\
\hline TRITIUM & $2.82 E-05$ & 3.24E-05 & & 6.06E-05 \\
\hline Pathway Totals & $2.82 \mathrm{E}-05$ & $3.48 \mathrm{E}-05$ & & $6.30 \mathrm{E}-05$ \\
\hline \multicolumn{5}{|c|}{ Recreational, Seep HRT-10 } \\
\hline SR-90 & $1.38 \mathrm{E}-06$ & $1.43 \mathrm{E}-04$ & & $1.45 E-04$ \\
\hline Pathway Totals & $1.38 \mathrm{E}-06$ & 1.43E-04 & & 1.45E-04 \\
\hline \multicolumn{5}{|c|}{ Recreational, Seep HRT-1A } \\
\hline SR-90 & 4.67E-06 & $4.85 E-04$ & & 4.89E-04 \\
\hline TRITIUM & 9.11E-06 & $1.05 E-05$ & & 1.96E-05 \\
\hline Pathway Totals & 1.38E-05 & $4.95 \mathrm{E}-04$ & & $5.09 \mathrm{E}-04$ \\
\hline \multicolumn{5}{|l|}{ Recreational ${ }_{i}$ Seep HRT-1B } \\
\hline SR-90 & 2.83E-06 & 2.93E-04 & & $2.96 \mathrm{E}-04$ \\
\hline TRITIUM & 7.96E-06 & 9.17E-06 & & 1.71E-05 \\
\hline
\end{tabular}




\begin{tabular}{|c|c|c|c|c|c|}
\hline Land Use/Site/Contaminant & Ingestion & $\begin{array}{c}\text { Producel } \\
\text { Fish }\end{array}$ & Dermal & Inhalation & Total Risk \\
\hline Pathway Totals & 1.08E-05 & $3.03 E-04$ & & & $3.13 E-04$ \\
\hline \multicolumn{6}{|l|}{ Recreational, Seep HRT-1C } \\
\hline SR-90 & 8.77E-06 & $9.10 E-04$ & & & $9.18 \mathrm{E}-04$ \\
\hline TRITIUM & $1.50 \mathrm{E}-05$ & $1.73 \mathrm{E}-05$ & & & $3.24 E-05$ \\
\hline Pathway Totals & $2.38 \mathrm{E}-05$ & $9.27 \mathrm{E}-04$ & & & $9.51 \mathrm{E}-04$ \\
\hline \multicolumn{6}{|l|}{ Recreational, Seep HRT-1D } \\
\hline SR-90 & $6.58 \mathrm{E}-06$ & $6.82 \mathrm{E}-04$ & & & $6.89 \mathrm{E}-04$ \\
\hline TRITIUM & 2.95E-05 & 3.39E-05 & & & 6.34E-05 \\
\hline Pathway Totals & $3.60 \mathrm{E}-05$ & $7.16 \mathrm{E}-04$ & & & $7.52 \mathrm{E}-04$ \\
\hline \multicolumn{6}{|l|}{ Recreational, Seep HRT-2 } \\
\hline SR-90 & 5.44E-06 & $5.64 \mathrm{E}-04$ & & & $5.69 \mathrm{E}-04$ \\
\hline TRITIUM & 9.03E-06 & $1.04 \mathrm{E}-05$ & & & $1.94 \mathrm{E}-05$ \\
\hline Pathway Totals & $1.45 E-05$ & $5.74 \mathrm{E}-04$ & & & 5.89E-04 \\
\hline \multicolumn{6}{|l|}{ Recreational, Seep HRT-2A } \\
\hline SR-90 & $7.45 E-06$ & $7.72 E-04$ & & & $7.80 \mathrm{E}-04$ \\
\hline TRITIUM & 7.37E-06 & $8.49 E-06$ & & & 1.59E-05 \\
\hline Pathway Totals & $1.48 \mathrm{E}-05$ & $7.81 E-04$ & & & $7.96 \mathrm{E}-04$ \\
\hline \multicolumn{6}{|l|}{ Recreational, Seep HRT-3 } \\
\hline AS & $3.11 E-08$ & & 2.95E-08 & & $6.06 E-08$ \\
\hline $\mathrm{BE}$ & 4.54E-08 & 5.23E-06 & 1.76E-06 & & $7.04 E-06$ \\
\hline SR-90 & 4.70E-06 & 4.87E-04 & & & 4.92E-04 \\
\hline TRITIUM & $6.20 E-09$ & 7.14E-09 & & & $1.33 E-08$ \\
\hline Pathway Totals & $4.78 \mathrm{E}-06$ & $4.93 E-04$ & $1.79 E-06$ & & $4.99 E-04$ \\
\hline \multicolumn{6}{|l|}{ Recreational, Seep HRT-4 } \\
\hline SR-90 & $4.75 E-06$ & $4.92 E-04$ & & & 4.97E-04 \\
\hline TRITIUM & 4.83E-09 & 5.56E-09 & & & $1.04 \mathrm{E}-08$ \\
\hline Pathway Totals & 4.75E-06 & 4.92E-04 & & & 4.97E-04 \\
\hline \multicolumn{6}{|l|}{ Recreational, Seep HRT-5 } \\
\hline SR-90 & $6.78 \mathrm{E}-06$ & $7.03 E-04$ & & & $7.10 \mathrm{E}-04$ \\
\hline Pathway Totals & $6.78 \mathrm{E}-06$ & $7.03 E-04$ & & & $7.10 \mathrm{E}-04$ \\
\hline \multicolumn{6}{|l|}{ Recreational; Seep HRT-6 } \\
\hline SR-90 & $4.52 \mathrm{E}-06$ & $4.68 \mathrm{E}-04$ & & & 4.73E-04 \\
\hline Pathway Totals & 4.52E-06 & $4.68 \mathrm{E}-04$ & & & 4.73E-04 \\
\hline \multicolumn{6}{|l|}{ Recreational, Seep HRT-7 } \\
\hline SR-90 & 2.96E-06 & 3.07E-04 & & & $3.10 \mathrm{E}-04$ \\
\hline Pathway Totals & 2.96E-06 & 3.07E-04 & & & 3.10E-04 \\
\hline \multicolumn{6}{|l|}{ Recreational, Seep HRT-8 } \\
\hline SR-90 & 1.67E-05 & $1.73 E-03$ & & & 1.75E-03 \\
\hline Pathway Totals & 1.67E-05 & $1.73 \mathrm{E}-03$ & & & $1.75 \mathrm{E}-03$ \\
\hline \multicolumn{6}{|l|}{ Recreational, Seep HRT-9 } \\
\hline SR-90 & $7.39 E-06$ & $7.66 \mathrm{E}-04$ & & & 7.73E-04 \\
\hline Pathway Totals & $7.39 \mathrm{E}-06$ & $7.66 \mathrm{E}-04$ & & & $7.73 \mathrm{E}-04$ \\
\hline \multicolumn{6}{|l|}{ Recreational, Seep MB-1 } \\
\hline & 1.02E-07 & & 9.65E-08 & & $1.98 \mathrm{E}-07$ \\
\hline $\mathrm{BE}$ & 1.88E-07 & 2.17E-05 & 7.31E-06 & & 2.92E-05 \\
\hline SR-90 & 3.53E-06 & 3.66E-04 & & & 3.70E-04 \\
\hline
\end{tabular}


Producel

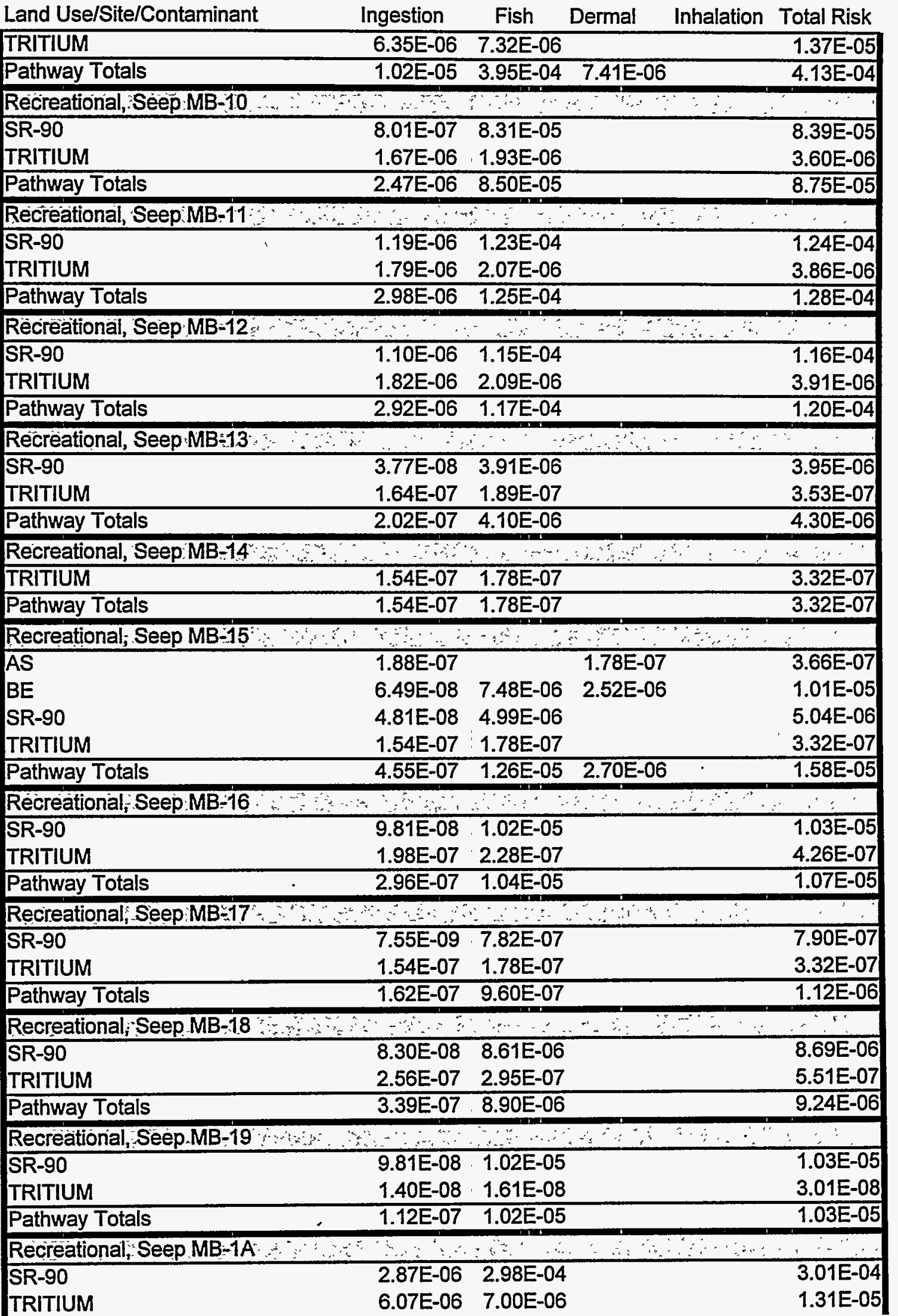




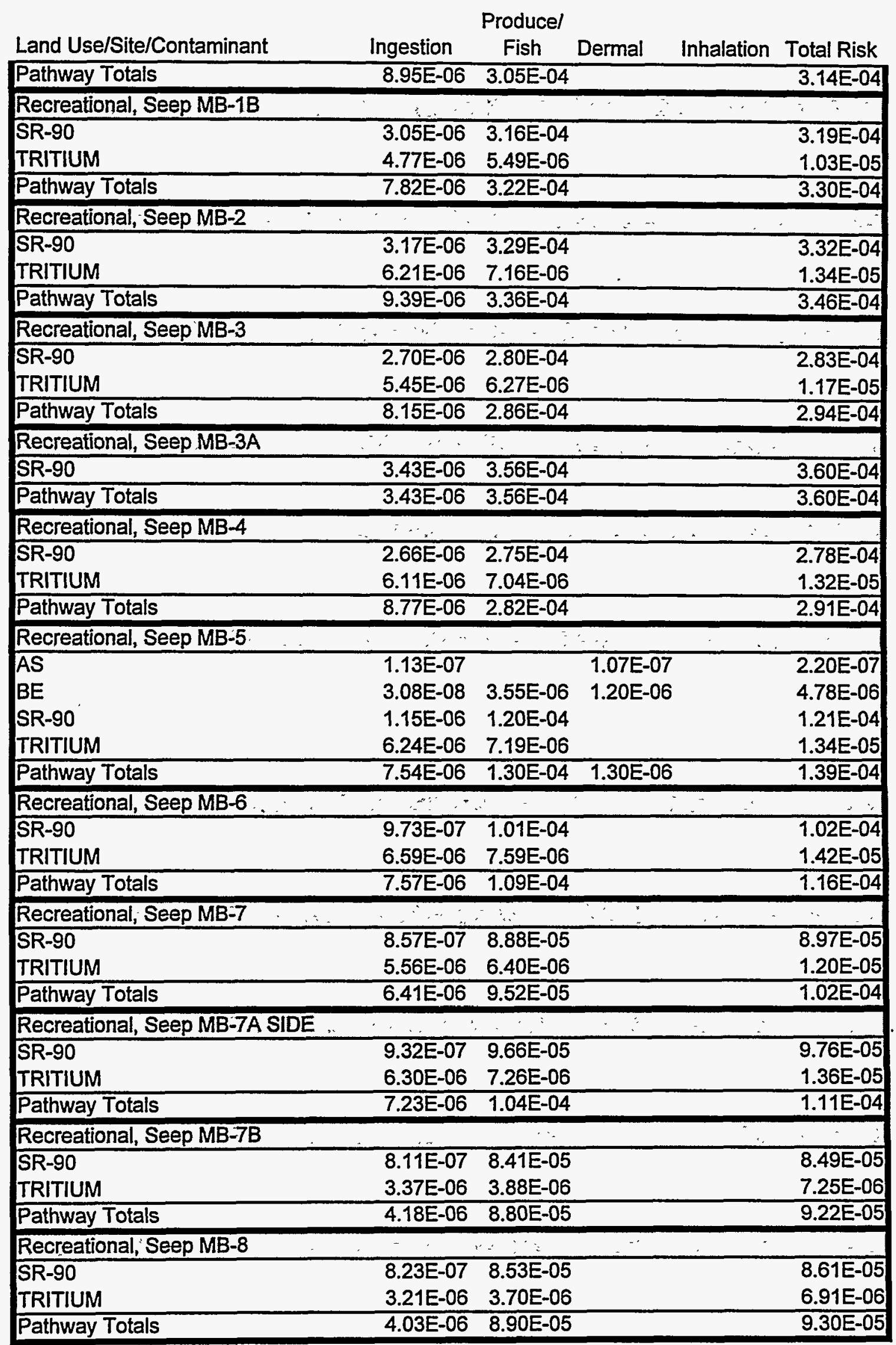


Produce/

\begin{tabular}{|c|c|c|c|c|}
\hline Land Use/Site/Contaminant & Ingestion & Fish & Inhalation & Total Risk \\
\hline Recreational, Seep MB: 9 & 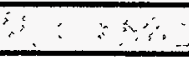 & $\because+\cdots, \cdots, \cdots$ & $\because$ & $\cdots$ \\
\hline SR-90 & $7.65 \mathrm{E}-07$ & 7.93E-05 & & $8.01 \mathrm{E}-05$ \\
\hline TRITIUM & 2.27E-06 & 2.61E-06 & & 4.88E-06 \\
\hline Pathway Totals & 3.03E-06 & $8.19 E-05$ & & $8.50 \mathrm{E}-05$ \\
\hline \multicolumn{5}{|l|}{ Recreational, Seep MBTRIB-1, } \\
\hline SR-90 & $8.30 E-08$ & 8.61E-06 & & 8.69E-06 \\
\hline TRITIUM & 9.65E-09 & 1.11E-08 & & 2.08E-08 \\
\hline Pathway Totals & $9.27 E-08$ & 8.62E-06 & & 8.71E-06 \\
\hline \multicolumn{5}{|l|}{ Recreational; Seep MBTRIB-2A } \\
\hline SR-90 & $1.28 \mathrm{E}-07$ & $1.33 \mathrm{E}-05$ & & 1.34E-05 \\
\hline TRITIUM & 3.80E-07 & 4.37E-07 & & 8.17E-07 \\
\hline Pathway Totals & $5.08 \mathrm{E}-07$ & 1.37E-05 & & $1.42 \mathrm{E}-05$ \\
\hline Recreational; Seep MBTRIB=2B & $\therefore$ & $\therefore \because \ldots$ & $\because$ & $\therefore$ \\
\hline SR-90 & $2.64 \mathrm{E}-08$ & 2.74E-06 & & 2.76E-06 \\
\hline TRITIUM & 7.60E-09 & 8.75E-09 & & 1.64E-08 \\
\hline Pathway Totals & $3.40 \mathrm{E}-08$ & $2.75 \mathrm{E}-06$ & & $2.78 \mathrm{E}-06$ \\
\hline \multicolumn{5}{|l|}{ Recreational, Seep MBTRIB $=3$} \\
\hline CHLOROFORM & $1.38 \mathrm{E}-09$ & $3.10 \mathrm{E}-08$ & $2.38 \mathrm{E}-08$ & 5.63E-08 \\
\hline CS-137 & $1.00 \mathrm{E}-08$ & 2.31E-05 & & 2.32E-05 \\
\hline SR-90 & 2.88E-07 & 2.98E-05 & & 3.01E-05 \\
\hline TRITIUM & 1.45E-08 & 1.67E-08 & & 3.12E-08 \\
\hline Pathway Totals & 3.13E-07 & $5.30 \mathrm{E}-05$ & $2.38 E-08$ & 5.33E-05 \\
\hline \multicolumn{5}{|l|}{ Recreational,'Seep'MBWEIR: } \\
\hline AS & $1.28 \mathrm{E}-07$ & & 1.21E-07 & $2.49 E-07$ \\
\hline BE & 8.11E-08 & $9.35 \mathrm{E}-06$ & 3.15E-06 & 1.26E-05 \\
\hline PU-238 & $3.98 E-09$ & 1.38E-07 & & 1.42E-07 \\
\hline TH-228 & 2.03E-08 & 1.31E-05 & & 1.31E-05 \\
\hline U-234 & 4.77E-09 & 5.49E-08 & & 5.97E-08 \\
\hline CS-137 & 9.11E-09 & 2.10E-05 & & 2.10E-05 \\
\hline SR-90 & 2.71E-06 & 2.81E-04 & & 2.84E-04 \\
\hline TRITIUM & 5.73E-06 & $6.60 E-06$ & & $1.23 E-05$ \\
\hline Pathway Totals & 8.69E-06 & $3.32 E-04$ & 3.27E-06 & $3.44 \mathrm{E}-04$ \\
\hline \multicolumn{5}{|l|}{ Recreational, Seep MID:DRAIN } \\
\hline AS & 4.53E-08 & & $4.29 E-08$ & $8.82 \mathrm{E}-08$ \\
\hline BE & 4.87E-08 & 5.61E-06 & 1.89E-06 & 7.55E-06 \\
\hline VINYL CHLORIDE & 3.59E-08 & 2.82E-07 & $1.02 E-07$ & 4.19E-07 \\
\hline SR-90 & 7.83E-06 & 8.12E-04 & & 8.20E-04 \\
\hline TRITIUM & 3.92E-05 & 4.51E-05 & & 8.43E-05 \\
\hline Pathway Totals & 4.71E-05 & $8.63 \mathrm{E}-04$ & 2.03E-06 & $9.12 \mathrm{E}-04$ \\
\hline \multicolumn{5}{|c|}{ Recreational; Seep MV-1 } \\
\hline$\overline{A S}$ & $1.30 \mathrm{E}-07$ & & $1.23 E-07$ & 2.53E-07 \\
\hline SR-90 & $1.52 \mathrm{E}-07$ & 1.58E-05 & & 1.59E-05 \\
\hline TRITIUM & 8.78E-09 & 1.01E-08 & & 1.89E-08 \\
\hline Pathway Totals & 2.91E-07 & $1.58 \mathrm{E}-05$ & 1.23E-07 & $1.62 \mathrm{E}-05$ \\
\hline \multicolumn{5}{|l|}{ Recreational, Seep:MV 3} \\
\hline SR-90 & -08 & -06 & & \\
\hline
\end{tabular}




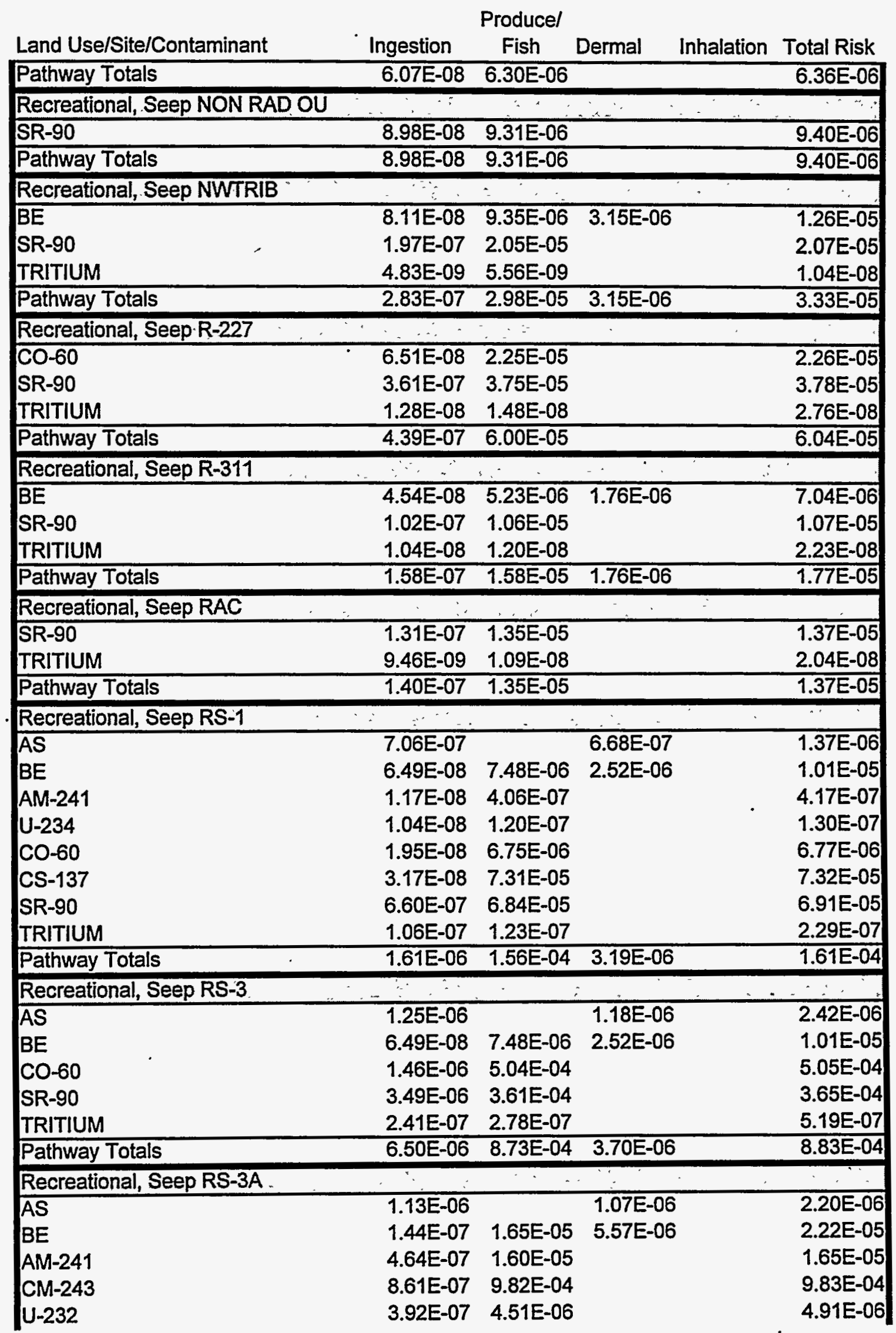


Producel

\begin{tabular}{|c|c|c|c|c|}
\hline Land Use/Site/Contaminant & Ingestion & Fish Dermal & Inhalation & Total Risk \\
\hline $\mathrm{U}-234$ & 4.47E-06 & $5.14 E-05$ & & 5.59E-05 \\
\hline$U-235$ & 1.97E-08 & 2.50E-06 & & 2.52E-06 \\
\hline$U-238$ & 2.69E-07 & 4.02E-05 & & $4.05 E-05$ \\
\hline $\operatorname{co-60}$ & 1.23E-06 & 4.25E-04 & & 4.26E-04 \\
\hline SR-90 & 4.08E-06 & 4.23E-04 & & 4.27E-04 \\
\hline TRITIUM & 2.18E-07 & 2.52E-07 & & 4.70E-07 \\
\hline Pathway Totals & 1.33E-05 & 1.96E-03 6.64E-06 & & 1.98E-03 \\
\hline \multicolumn{5}{|l|}{ Recreational; Seep, RS-3B } \\
\hline PU-238 & 4.58E-09 & $1.58 E-07$ & & 1.63E-07 \\
\hline U-232 & 3.09E-08 & 3.55E-07 & & 3.86E-07 \\
\hline U-234 & 4.02E-07 & 4.63E-06 & & 5.03E-06 \\
\hline$U-238$ & 2.78E-08 & 4.16E-06 & & 4.19E-06 \\
\hline CO-60 & $1.68 \mathrm{E}-07$ & 5.81E-05 & & 5.83E-05 \\
\hline CS-137 & 1.77E-08 & 4.07E-05 & & 4.08E-05 \\
\hline SR-90 & $1.75 E-07$ & 1.81E-05 & & 1.83E-05 \\
\hline TRITIUM & 8.29E-08 & 9.55E-08 & & 1.78E-07 \\
\hline Pathway Totals & $9.08 E-07$ & $1.26 \mathrm{E}-04$ & & 1.27E-04 \\
\hline \multicolumn{5}{|c|}{ Recreational; Seep SPD } \\
\hline AS & $1.25 \mathrm{E}-07$ & 1.18E-07 & & 2.42E-07 \\
\hline BE & 2.27E-08 & $2.62 E-06 \quad 8.82 E-07$ & & $3.52 E-06$ \\
\hline SR-90 & $2.48 \mathrm{E}-04$ & 2.54E-02 & & $2.56 \mathrm{E}-02$ \\
\hline TRITIUM & 5.47E-05 & $6.30 E-05$ & & 1.18E-04 \\
\hline Pathway Totals & 3.03E-04 & 2.54E-02 9.99E-07 & & $2.57 \mathrm{E}-02$ \\
\hline \multicolumn{5}{|l|}{ Recreational, Seep SW2 $=1$. } \\
\hline $\mathrm{BE}$ & $6.49 \mathrm{E}-08$ & $7.48 \mathrm{E}-06 \quad 2.52 \mathrm{E}-06$ & & 1.01E-05 \\
\hline CS-137 & 6.83E-09 & $1.58 E-05$ & & $1.58 E-05$ \\
\hline SR-90 & 1.38E-06 & $1.43 E-04$ & & $1.44 E-04$ \\
\hline TRITIUM & 5.49E-08 & 6.33E-08 & & 1.18E-07 \\
\hline Pathway Totals & 1.50E-06 & $1.66 \mathrm{E}-04 \quad 2.52 \mathrm{E}-06$ & & $1.70 \mathrm{E}-04$ \\
\hline \multicolumn{5}{|l|}{ Recreational, Seep SW2-2: } \\
\hline $\mathrm{BE}$ & $9.74 \mathrm{E}-08$ & $1.12 \mathrm{E}-05 \quad 3.78 \mathrm{E}-06$ & & 1.51E-05 \\
\hline CS-137 & 7.68E-09 & 1.77E-05 & & 1.77E-05 \\
\hline SR-90 & $2.80 \mathrm{E}-06$ & 2.90E-04 & & 2.93E-04 \\
\hline TRITIUM & $2.41 E-08$ & $2.78 \mathrm{E}-08$ & & 5.19E-08 \\
\hline Pathway Totals & 2.93E-06 & $3.19 \mathrm{E}-04 \quad 3.78 \mathrm{E}-06$ & & $3.26 \mathrm{E}-04$ \\
\hline \multicolumn{5}{|l|}{ Recreational, Seep SW2-3 } \\
\hline $\mathrm{BE}$ & $8.11 \mathrm{E}-08$ & $9.35 \mathrm{E}-06 \quad 3.15 \mathrm{E}-06$ & & $1.26 \mathrm{E}-05$ \\
\hline SR-90 & 7.51E-08 & 7.79E-06 & & 7.86E-06 \\
\hline TRITIUM & $3.38 \mathrm{E}-08$ & 3.89E-08 & & 7.27E-08 \\
\hline Pathway Totals & $1.90 \mathrm{E}-07$ & $1.72 \mathrm{E}-05 \quad 3.15 \mathrm{E}-06$ & & $2.05 E-05$ \\
\hline \multicolumn{5}{|l|}{ Recreational, Seep SW2-4 } \\
\hline$\overline{A S}$ & 1.70E-07 & 1.61E-07 & & 3.31E-07 \\
\hline $\mathrm{CO}-60$ & 5.57E-09 & $1.92 E-06$ & & 1.93E-06 \\
\hline CS -137 & $6.48 E-08$ & $1.50 \mathrm{E}-04$ & & $1.50 E-04$ \\
\hline SR-90 & 1.34E-06 & 1.39E-04 & & 1.40E-04 \\
\hline TRITIUM & 5.97E-06 & 6.88E-06 & & $1.28 \mathrm{E}-05$ \\
\hline
\end{tabular}


Producel

\begin{tabular}{|c|c|c|c|c|}
\hline Land Use/Site/Contaminant & Ingestion & Fish & Dermal & Inhalation Total Risk \\
\hline Pathway Totals & $7.55 \mathrm{E}-06$ & $2.97 E-04$ & 1.61E-07 & $3.05 \mathrm{E}-04$ \\
\hline \multicolumn{5}{|l|}{ Recreational,'Seep SW2-5. } \\
\hline$\overline{B E}$ & $2.76 \mathrm{E}-08$ & $3.18 E-06$ & 1.07E-06 & $4.28 E-06$ \\
\hline SR-90 & 5.23E-04 & 5.28E-02 & & $5.33 E-02$ \\
\hline TRITIUM & 5.30E-05 & $6.11 E-05$ & & $1.14 E-04$ \\
\hline Pathway Totals & $5.76 E-04$ & $5.29 E-02$ & 1.07E-06 & 5.34E-02 \\
\hline \multicolumn{5}{|l|}{ Recreational, Seep SW2-6 } \\
\hline AS & $5.66 \mathrm{E}-08$ & & $5.36 \mathrm{E}-08$ & $1.10 \mathrm{E}-07$ \\
\hline$B E$ & 2.76E-08 & 3.18E-06 & 1.07E-06 & 4.28E-06 \\
\hline SR-90 & 1.93E-03 & 1.81E-01 & & $1.83 E-01$ \\
\hline TRITIUM & 1.37E-05 & 1.57E-05 & & 2.94E-05 \\
\hline Pathway Totals & 1.94E-03 & 1.81E-01 & $1.12 E-06$ & $1.83 E-01$ \\
\hline \multicolumn{5}{|l|}{ Recreational, Seep SW2-7. } \\
\hline AS & 7.93E-08 & & $7.50 \mathrm{E}-08$ & $1.54 \mathrm{E}-07$ \\
\hline$B E$ & 4.71E-08 & 5.42E-06 & $1.83 E-06$ & 7.29E-06 \\
\hline SR-90 & 9.11E-04 & $9.02 E-02$ & & $9.10 \mathrm{E}-02$ \\
\hline TRITIUM & $1.31 E-05$ & $1.51 \mathrm{E}-05$ & & 2.81E-05 \\
\hline Pathway Totals & $9.25 E-04$ & $9.02 E-02$ & $1.90 \mathrm{E}-06$ & $9.10 E-02$ \\
\hline \multicolumn{5}{|l|}{ Recreational, Seep SW4-1 } \\
\hline$\overline{A S}$ & $3.51 E-07$ & & $3.32 E-07$ & $6.83 E-07$ \\
\hline$B E$ & $1.30 E-07$ & $1.50 E-05$ & 5.04E-06 & 2.01E-05 \\
\hline 1,1-DICHLOROETHENE & $1.13 E-08$ & $1.79 E-07$ & 3.91E-08 & 2.30E-07 \\
\hline TRICHLOROETHENE & 3.74E-09 & 1.69E-07 & $1.55 E-07$ & 3.27E-07 \\
\hline VINYL CHLORIDE & $9.84 \mathrm{E}-07$ & 7.73E-06 & 2.79E-06 & 1.15E-05 \\
\hline TH-228 & $1.48 \mathrm{E}-08$ & $9.56 \mathrm{E}-06$ & & 9.57E-06 \\
\hline U-234 & $1.45 \mathrm{E}-08$ & 1.67E-07 & & 1.82E-07 \\
\hline U-238 & $1.02 E-08$ & 1.52E-06 & & 1.53E-06 \\
\hline SR-90 & 2.14E-05 & $2.22 E-03$ & & 2.24E-03 \\
\hline TRITIUM & 5.69E-06 & $6.56 \mathrm{E}-06$ & & 1.23E-05 \\
\hline Pathway Totals & $2.86 \mathrm{E}-05$ & $2.26 \mathrm{E}-03$ & $8.35 \mathrm{E}-06$ & $2.30 \mathrm{E}-03$ \\
\hline \multicolumn{5}{|l|}{ Recreational, Seep SW4-2 } \\
\hline$\overline{B E}$ & $1.02 \mathrm{E}-07$ & $1.18 \mathrm{E}-05$ & $3.96 E-06$ & $1.58 \mathrm{E}-05$ \\
\hline 1,1-DICHLOROETHENE & 4.53E-08 & 7.17E-07 & $1.56 \mathrm{E}-07$ & 9.19E-07 \\
\hline BENZENE & 3.28E-09 & 8.79E-08 & 2.76E-08 & 1.19E-07 \\
\hline TETRACHLOROETHENE & 5.89E-09 & 3.78E-07 & 8.45E-07 & 1.23E-06 \\
\hline TRICHLOROETHENE & $3.32 E-09$ & $1.50 \mathrm{E}-07$ & 1.37E-07 & 2.91E-07 \\
\hline VINYL CHLORIDE & 4.52E-06 & $3.55 \mathrm{E}-05$ & $1.28 E-05$ & 5.28E-05 \\
\hline TH-228 & 2.03E-08 & 1.31E-05 & & 1.31E-05 \\
\hline$U-234$ & $1.25 E-08$ & 1.44E-07 & & 1.57E-07 \\
\hline CS-137 & $1.30 \mathrm{E}-06$ & 3.01E-03 & & 3.01E-03 \\
\hline SR-90 & 5.06E-05 & $5.24 \mathrm{E}-03$ & & 5.29E-03 \\
\hline TRITIUM & $1.03 \mathrm{E}-07$ & 1.19E-07 & & 2.22E-07 \\
\hline Pathway Totals & $5.67 E-05$ & $8.31 E-03$ & 1.79E-05 & 8.39E-03 \\
\hline \multicolumn{5}{|l|}{ Recreational, Seep SW5-1 } \\
\hline$\overline{\mathrm{AS}}$ & $1.98 \mathrm{E}-07$ & & $1.88 \mathrm{E}-07$ & 3.86E-07 \\
\hline BE & 1.30E-07 & 1.50E-05 & 5.04E-06 & 2.01E-05 \\
\hline
\end{tabular}




\begin{tabular}{|c|c|c|c|c|c|}
\hline & & Producel & & & \\
\hline Land Use/Site/Contaminant & Ingestion & Fish & Dermal & Inhalation & Total Risk \\
\hline TRICHLOROETHENE & $8.30 \mathrm{E}-10$ & $3.76 E-08$ & $3.44 \mathrm{E}-08$ & & $7.28 E-08$ \\
\hline VINYL CHLORIDE & 1.43E-07 & 1.13E-06 & 4.06E-07 & & $1.68 E-06$ \\
\hline SR-90 & 4.34E-07 & 4.50E-05 & & & 4.54E-05 \\
\hline TC-99 & 5.90E-09 & $1.36 \mathrm{E}-07$ & & & $1.42 E-07$ \\
\hline TRITIUM & $3.42 E-06$ & 3.94E-06 & & & 7.36E-06 \\
\hline$U-233 / 234$ & 1.26E-08 & $1.45 \mathrm{E}-07$ & & & $1.58 E-07$ \\
\hline U-238 & 1.13E-08 & 1.69E-06 & & & 1.70E-06 \\
\hline Pathway Totals & 4.36E-06 & 6.70E-05 & 5.67E-06 & & $7.70 E-05$ \\
\hline Recreational, Seep SW5:11 & 1 & $\cdots$ & & & $\therefore \quad$. \\
\hline $\mathrm{BE}$ & 6.49E-08 & $7.48 \mathrm{E}-06$ & 2.52E-06 & & 1.01E-05 \\
\hline C-14 & $3.55 E-08$ & & & & $3.55 E-08$ \\
\hline $\mathrm{CA}-45$ & 2.05E-06 & & & & 2.05E-06 \\
\hline SR-90 & 4.46E-03 & 3.70E-01 & & & 3.73E-01 \\
\hline TC-99 & $1.49 \mathrm{E}-07$ & 3.44E-06 & & & $3.59 E-06$ \\
\hline TH-228 & 4.52E-09 & 2.92E-06 & & & 2.92E-06 \\
\hline TRITIUM & 4.70E-04 & 5.41E-04 & & & 1.01E-03 \\
\hline$U-233 / 234$ & 1.14E-06 & $1.31 E-05$ & & & $1.43 E-05$ \\
\hline $\mathrm{U}-238$ & 6.82E-09 & $1.02 E-06$ & & & 1.03E-06 \\
\hline Pathway Totals & 4.93E-03 & 3.70E-01 & $2.52 E-06$ & & 3.74E-01 \\
\hline Recreational, Seep_SW5-2. & $\because x^{n}$ & $\therefore$ & & 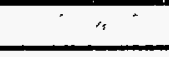 & - \\
\hline $\mathrm{BE}$ & $1.14 \mathrm{E}-07$ & $1.31 \mathrm{E}-05$ & 4.41E-06 & & $1.76 \mathrm{E}-05$ \\
\hline CHLOROFORM & $4.60 E-10$ & $1.03 E-08$ & 7.95E-09 & & $1.88 \mathrm{E}-08$ \\
\hline TRICHLOROETHENE & 3.16E-08 & $1.43 E-06$ & 1.31E-06 & & 2.76E-06 \\
\hline $\mathrm{C}-14$ & 6.81E-09 & & & & 6.81E-09 \\
\hline co-60 & $4.04 \mathrm{E}-08$ & $1.40 E-05$ & & & $1.40 E-05$ \\
\hline CS-137 & $5.64 E-08$ & $1.30 E-04$ & & & 1.30E-04 \\
\hline RA-228 & 4.55E-07 & 2.62E-05 & & & 2.67E-05 \\
\hline SR-90 & $9.68 \mathrm{E}-07$ & $1.00 E-04$ & & & 1.01E-04 \\
\hline TRITIUM & $1.54 \mathrm{E}-07$ & $1.78 \mathrm{E}-07$ & & & 3.32E-07 \\
\hline Pathway Totals & 1.83E-06 & 2.85E-04 & 5.72E-06 & & 2.93E-04 \\
\hline Recreational, Sëep SW5-3 & $\because \quad \cdots$ & $\therefore$ & & 4 & \\
\hline $\mathrm{BE}$ & $6.49 E-08$ & $7.48 E-06$ & $2.52 E-06$ & & 1.01E-05 \\
\hline CHLOROFORM & $4.60 \mathrm{E}-10$ & $1.03 E-08$ & 7.95E-09 & & $1.88 E-08$ \\
\hline TRICHLOROETHENE & 7.06E-09 & 3.19E-07 & 2.92E-07 & & $6.18 \mathrm{E}-07$ \\
\hline C-14 & 4.38E-08 & & & & 4.38E-08 \\
\hline$C A-45$ & 1.64E-08 & & & & 1.64E-08 \\
\hline CS-137 & 4.69E-09 & $1.08 E-05$ & & & 1.08E-05 \\
\hline$K-40$ & 1.27E-07 & & & & 1.27E-07 \\
\hline SR-90 & 7.53E-06 & 7.81E-04 & & & 7.88E-04 \\
\hline TC-99 & $2.00 \mathrm{E}-08$ & 4.61E-07 & & & 4.81E-07 \\
\hline TRITIUM & 4.73E-05 & 5.45E-05 & & & 1.02E-04 \\
\hline Pathway Totals & 5.51E-05 & 8.54E-04 & $2.82 E-06$ & & $9.12 \mathrm{E}-04$ \\
\hline Recreational, Seep SW5:4 & 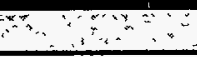 & $\therefore \cdots$ & & & - \\
\hline$\overline{A S}$ & $1.70 \mathrm{E}-07$ & & 1.61E-07 & & 3.31E-07 \\
\hline $\mathrm{BE}$ & 6.49E-08 & 7.48E-06 & 2.52E-06 & & 1.01E-05 \\
\hline$A M-241$ & 4.61E-08 & 1.59E-06 & & & 1.64E-06 \\
\hline CM-243 & 2.57E-07 & 2.93E-04 & & & 2.93E-04 \\
\hline
\end{tabular}


Producel

\begin{tabular}{|c|c|c|c|c|c|}
\hline Land Use/Site/Contaminant & Ingestion & Fish & Dermal & Inhalation & Total Risk \\
\hline PU-238 & 8.96E-09 & $3.10 \mathrm{E}-07$ & & & $3.19 \mathrm{E}-07$ \\
\hline TH-228 & 1.06E-08 & 6.84E-06 & & & 6.85E-06 \\
\hline C-14 & 2.02E-08 & & & & 2.02E-08 \\
\hline CA-45 & 1.20E-06 & & & & 1.20E-06 \\
\hline SR-90 & $1.74 \mathrm{E}-03$ & 1.65E-01 & & & 1.66E-01 \\
\hline TC-99 & 2.00E-07 & 4.62E-06 & & & 4.82E-06 \\
\hline TRITIUM & 2.95E-05 & $3.40 \mathrm{E}-05$ & & & $6.36 \mathrm{E}-05$ \\
\hline Pathway Totals & 1.77E-03 & $1.65 \mathrm{E}-01$ & $2.68 \mathrm{E}-06$ & & $1.67 \mathrm{E}-01$ \\
\hline \multicolumn{6}{|l|}{ Recreational, Seep SW5-5 } \\
\hline$\overline{\mathrm{BE}}$ & $7.79 E-08$ & 8.97E-06 & 3.02E-06 & & 1.21E-05 \\
\hline TRICHLOROETHENE & 1.25E-09 & 5.63E-08 & $5.15 E-08$ & & 1.09E-07 \\
\hline VINYL CHLORIDE & 1.15E-06 & $9.02 E-06$ & $3.25 E-06$ & & 1.34E-05 \\
\hline C-14 & 2.92E-08 & & & & 2.92E-08 \\
\hline SR-90 & 4.83E-06 & $5.00 \mathrm{E}-04$ & & & $5.05 E-04$ \\
\hline TC-99 & 3.73E-09 & 8.60E-08 & & & 8.97E-08 \\
\hline TH-228 & $3.74 E-09$ & 2.41E-06 & & & $2.42 E-06$ \\
\hline TRITIUM & 5.46E-05 & 6.29E-05 & & & 1.18E-04 \\
\hline$U-233 / 234$ & 5.99E-09 & $6.91 E-08$ & & & $7.50 E-08$ \\
\hline Pathway Totals & 6.07E-05 & $5.84 \mathrm{E}-04$ & $6.32 \mathrm{E}-06$ & & $6.51 E-04$ \\
\hline \multicolumn{6}{|l|}{ Recreational, Seep SW5-6 } \\
\hline $\mathrm{BE}$ & $4.87 \mathrm{E}-08$ & $5.61 \mathrm{E}-06$ & $1.89 \mathrm{E}-06$ & & $7.55 \mathrm{E}-06$ \\
\hline 1,2-DICHLOROPROPANE & 2.57E-09 & $5.76 \mathrm{E}-08$ & 1.35E-08 & & 7.37E-08 \\
\hline TRICHLOROETHENE & 2.08E-09 & 9.39E-08 & 8.59E-08 & & $1.82 E-07$ \\
\hline VINYL CHLORIDE & $5.74 E-07$ & 4.51E-06 & $1.62 E-06$ & & $6.71 E-06$ \\
\hline AM-241 & 7.13E-07 & 2.46E-05 & & & 2.54E-05 \\
\hline C-14 & 3.89E-08 & & & & 3.89E-08 \\
\hline RA-226 & 5.59E-09 & 2.96E-06 & & & 2.97E-06 \\
\hline SR-90 & 1.61E-04 & $1.65 E-02$ & & & 1.67E-02 \\
\hline TRITIUM & 5.16E-05 & $5.95 E-05$ & & & 1.11E-04 \\
\hline Pathway Totals & 2.14E-04 & $1.66 \mathrm{E}-02$ & 3.61E-06 & & $1.68 \mathrm{E}-02$ \\
\hline \multicolumn{6}{|l|}{ Recreational, Seep SW5-7 } \\
\hline$\overline{A S}$ & 1.70E-07 & & 1.61E-07 & & 3.31E-07 \\
\hline$B E$ & 4.87E-08 & 5.61E-06 & $1.89 E-06$ & & 7.55E-06 \\
\hline CS-137 & 8.19E-08 & 1.89E-04 & & & 1.89E-04 \\
\hline SR-90 & 1.76E-05 & 1.82E-03 & & & $1.84 \mathrm{E}-03$ \\
\hline TRITIUM & 6.11E-04 & 7.04E-04 & & & 1.32E-03 \\
\hline Pathway Totals & $6.29 \mathrm{E}-04$ & $2.72 E-03$ & 2.05E-06 & & $3.35 \mathrm{E}-03$ \\
\hline \multicolumn{6}{|l|}{ Recreational, Seep SW5-8 } \\
\hline ALPHA-BHC & $9.51 E-08$ & $5.94 \mathrm{E}-05$ & 7.16E-07 & & $6.02 E-05$ \\
\hline BETA-BHC & 4.62E-09 & 3.44E-06 & 4.37E-08 & & $3.48 E-06$ \\
\hline DICHLOROBENZENE,1,4- & 6.34E-09 & 1.65E-06 & $1.70 \mathrm{E}-07$ & & 1.83E-06 \\
\hline $\mathrm{C}-14$ & 1.04E-08 & & & & $1.04 E-08$ \\
\hline$C A-45$ & 6.27E-09 & & & & 6.27E-09 \\
\hline CS-137 & 1.62E-08 & 3.74E-05 & & & 3.74E-05 \\
\hline RA-228 & 2.51E-07 & $1.45 \mathrm{E}-05$ & & & 1.47E-05 \\
\hline SR-90 & 1.11E-06 & 1.15E-04 & & & 1.16E-04 \\
\hline TRITIUM & $1.72 E-04$ & 1.99E-04 & & & 3.71E-04 \\
\hline
\end{tabular}


Produce/

\begin{tabular}{|c|c|c|c|c|c|}
\hline Land Use/Site/Contaminant & Ingestion & Fish & Dermal & Inhalation & Total Risk \\
\hline Pathway Totals & 1.74E-04 & 4.30E-04 & 9.29E-07 & & $6.05 E-04$ \\
\hline \multicolumn{6}{|c|}{ Rëcreational, Seep:SW5-9 } \\
\hline$\widehat{A S}$ & 1.70E-07 & & $1.61 \mathrm{E}-07$ & & 3.31E-07 \\
\hline$B E$ & 6.49E-08 & $7.48 \mathrm{E}-06$ & $2.52 E-06$ & & 1.01E-05 \\
\hline DICHLOROBENZENE,1,4- & $6.34 E-09$ & $1.65 \mathrm{E}-06$ & $1.70 \mathrm{E}-07$ & & 1.83E-06 \\
\hline TRICHLOROETHENE & 2.49E-09 & 1.13E-07 & 1.03E-07 & & 2.18E-07 \\
\hline VINYL CHLORIDE & 1.43E-07 & 1.13E-06 & 4.06E-07 & & 1.68E-06 \\
\hline C-14 & 1.95E-08 & & & & $1.95 E-08$ \\
\hline CS-137 & 3.85E-08 & 8.88E-05 & & & 8.88E-05 \\
\hline SR-90 & 2.65E-06 & 2.74E-04 & & & 2.77E-04 \\
\hline TRITIUM & 1.97E-04 & 2.27E-04 & & & 4.24E-04 \\
\hline Pathway Totals & $2.00 \mathrm{E}-04$ & $6.00 \mathrm{E}-04$ & $3.36 \mathrm{E}-06$ & & $8.04 E-04$ \\
\hline \multicolumn{6}{|l|}{ Recreational, Séep:SW6:-1 } \\
\hline$\overline{\mathrm{BE}}$ & $3.25 \mathrm{E}-08$ & $3.74 \mathrm{E}-06$ & $1.26 \mathrm{E}-06$ & & 5.03E-06 \\
\hline $\mathrm{CO}-60$ & 3.49E-08 & 1.21E-05 & & & 1.21E-05 \\
\hline CS-137 & 2.92E-08 & $6.75 E-05$ & & & $6.75 E-05$ \\
\hline SR-90 & 3.77E-08 & 3.91E-06 & & & 3.95E-06 \\
\hline TRITIUM & 1.07E-06 & 1.23E-06 & & & 2.30E-06 \\
\hline Pathway Totals & 1.20E-06 & 8.84E-05 & 1.26E-06 & & 9.09E-05 \\
\hline \multicolumn{6}{|l|}{ Recreational, Seep SW6-2 } \\
\hline AS & $1.13 E-07$ & & 1.07E-07 & & $2.20 E-07$ \\
\hline TRITIUM & 7.89E-06 & 9.09E-06 & & & 1.70E-05 \\
\hline Pathway Totals & $8.00 \mathrm{E}-06$ & $9.09 \mathrm{E}-06$ & 1.07E-07 & & 1.72E-05 \\
\hline \multicolumn{6}{|c|}{ Recreational, Seep SW7-1, } \\
\hline$\overline{\mathrm{BE}}$ & $6.49 E-08$ & $7.48 \mathrm{E}-06$ & $2.52 E-06$ & & 1.01E-05 \\
\hline SR-90 & 2.63E-07 & 2.72E-05 & & & 2.75E-05 \\
\hline TRITIUM & 1.31E-07 & 1.51E-07 & & & 2.81E-07 \\
\hline Pathway Totals & $4.58 \mathrm{E}-07$ & $3.49 \mathrm{E}-05$ & $2.52 \mathrm{E}-06$ & & 3.78E-05 \\
\hline \multicolumn{6}{|l|}{ Recreational,-Seep SW7-2 } \\
\hline $\mathrm{BE}$ & $6.49 E-08$ & $7.48 E-06$ & $2.52 \mathrm{E}-06$ & & $1.01 \mathrm{E}-05$ \\
\hline CO-60 & 1.99E-06 & 6.89E-04 & & & 6.91E-04 \\
\hline CS-137 & 3.75E-08 & 8.66E-05 & & & 8.67E-05 \\
\hline SR-90 & 1.09E-07 & 1.13E-05 & & & 1.14E-05 \\
\hline TRITIUM & 4.08E-08 & 4.69E-08 & & & 8.77E-08 \\
\hline Pathway Totals & $2.24 \mathrm{E}-06$ & $7.94 \mathrm{E}-04$ & $2.52 \mathrm{E}-06$ & & $7.99 E-04$ \\
\hline \multicolumn{6}{|c|}{ Recreational, Seep:SW7-3 } \\
\hline AS & $2.00 \mathrm{E}-07$ & & $1.90 \mathrm{E}-07$ & & 3.90E-07 \\
\hline $\mathrm{BE}$ & 8.11E-08 & $9.35 E-06$ & $3.15 \mathrm{E}-06$ & & 1.26E-05 \\
\hline AM-241 & 2.08E-08 & 7.19E-07 & & & 7.40E-07 \\
\hline CM-243 & 4.80E-08 & 5.47E-05 & & & 5.48E-05 \\
\hline TH-228 & 1.72E-08 & 1.11E-05 & & & 1.11E-05 \\
\hline U-232 & 1.23E-06 & 1.42E-05 & & & $1.54 \mathrm{E}-05$ \\
\hline$U-234$ & 1.24E-05 & 1.43E-04 & & & 1.55E-04 \\
\hline U-235 & 4.76E-08 & 6.03E-06 & & & $6.08 \mathrm{E}-06$ \\
\hline U-238 & 4.23E-07 & 6.33E-05 & & & 6.37E-05 \\
\hline$c 0-60$ & 4.42E-06 & 1.53E-03 & & & $1.53 E-03$ \\
\hline
\end{tabular}




\begin{tabular}{|c|c|c|c|c|c|}
\hline & & Produce/ & & & \\
\hline Land Use/Site/Contaminant & Ingestion & Fish & Dermal & Inhalation & Total Risk \\
\hline SR-90 & 2.57E-07 & 2.67E-05 & & & 2.69E-05 \\
\hline TRITIUM & 1.38E-07 & $1.59 \mathrm{E}-07$ & & & 2.97E-07 \\
\hline Pathway Totals & $1.93 \mathrm{E}-05$ & $1.86 \mathrm{E}-03$ & $3.34 \mathrm{E}-06$ & & $1.88 \mathrm{E}-03$ \\
\hline Recreational, Seep SW7-4 & $\therefore$ & & & & \\
\hline$\overline{\mathrm{BE}}$ & $8.11 E-08$ & $9.35 E-06$ & 3.15E-06 & & $1.26 \mathrm{E}-05$ \\
\hline co-60 & 2.11E-07 & 7.28E-05 & & & 7.30E-05 \\
\hline CS-137 & 2.44E-08 & 5.64E-05 & & & 5.64E-05 \\
\hline SR-90 & 1.89E-07 & 1.96E-05 & & & 1.97E-05 \\
\hline TRITIUM & 2.27E-07 & 2.61E-07 & & & 4.88E-07 \\
\hline Pathway Totals & $7.32 E-07$ & $1.58 \mathrm{E}-04$ & $3.15 \mathrm{E}-06$ & & $1.62 \mathrm{E}-04$ \\
\hline Recreational, Seep SW7-5 & $\because$ & & & & \\
\hline $\mathrm{BE}$ & 1.59E-07 & $1.83 E-05$ & 6.17E-06 & & 2.46E-05 \\
\hline METHYLENE CHLORIDE & 8.49E-09 & $5.60 E-08$ & 1.56E-08 & & 8.01E-08 \\
\hline CO-60 & $1.04 E-05$ & $3.59 E-03$ & & & 3.60E-03 \\
\hline SR-90 & $7.55 E-08$ & 7.82E-06 & & & 7.90E-06 \\
\hline TRITIUM & 4.25E-07 & 4.89E-07 & & & 9.14E-07 \\
\hline Pathway Totals & 1.11E-05 & $3.62 \mathrm{E}-03$ & $6.18 E-06$ & & $3.64 E-03$ \\
\hline Recreational, Seep SW7-6 & & & & & \\
\hline$\overline{B E}$ & 3.25E-08 & $3.74 E-06$ & $1.26 \mathrm{E}-06$ & & 5.03E-06 \\
\hline CS -137 & 7.21E-07 & 1.66E-03 & & & 1.66E-03 \\
\hline SR-90 & 4.34E-06 & 4.50E-04 & & & 4.54E-04 \\
\hline TRITIUM & $1.76 E-08$ & 2.03E-08 & & & 3.79E-08 \\
\hline Pathway Totals & 5.11E-06 & $2.12 E-03$ & $1.26 \mathrm{E}-06$ & & $2.12 E-03$ \\
\hline Recreational, Seep SW7-7 & & & & & \\
\hline$\overline{\mathrm{BE}}$ & $3.25 E-08$ & 3.74E-06 & 1.26E-06 & & 5.03E-06 \\
\hline CO-60 & 2.39E-07 & 8.25E-05 & & & 8.28E-05 \\
\hline CS-137 & $2.59 E-08$ & 5.97E-05 & & & 5.98E-05 \\
\hline SR-90 & 1.81E-07 & 1.88E-05 & & & $1.90 E-05$ \\
\hline TRITIUM & 1.64E-07 & 1.89E-07 & & & $3.53 E-07$ \\
\hline Pathway Totals & $6.42 E-07$ & 1.65E-04 & $1.26 \mathrm{E}-06$ & & 1.67E-04 \\
\hline Recreational, Seep SW7-8 & & & & & \\
\hline$\overline{\mathrm{BE}}$ & $3.25 E-08$ & $3.74 E-06$ & $1.26 E-06$ & & 5.03E-06 \\
\hline SR-90 & 1.31E-07 & 1.36E-05 & & & 1.37E-05 \\
\hline TRITIUM & 3.99E-08 & 4.59E-08 & & & 8.58E-08 \\
\hline Pathway Totals & 2.04E-07 & 1.74E-05 & 1.26E-06 & & $1.89 \mathrm{E}-05$ \\
\hline Recreational, Seep SW9-1 & $\because$ & $\therefore$ & & & \\
\hline CHLOROFORM & 1.15E-09 & $2.59 E-08$ & 1.99E-08 & & 4.69E-08 \\
\hline SR-90 & 3.33E-06 & 3.45E-04 & & & $3.49 E-04$ \\
\hline TRITIUM & $1.31 E-08$ & $1.51 \mathrm{E}-08$ & & & 2.83E-08 \\
\hline Pathway Totals & 3.35E-06 & $3.45 \mathrm{E}-04$ & $1.99 \mathrm{E}-08$ & & $3.49 \mathrm{E}-04$ \\
\hline Recreational, Seep SW9-2 & & & & & \\
\hline CHLOROFORM & $1.38 \mathrm{E}-10$ & $3.10 \mathrm{E}-09$ & $2.38 \mathrm{E}-09$ & & 5.63E-09 \\
\hline SR-90 & 7.02E-07 & 7.28E-05 & & & 7.35E-05 \\
\hline TRITIUM & 4.34E-09 & 5.00E-09 & & & 9.35E-09 \\
\hline Pathway Totals & 7.06E-07 & $7.28 \mathrm{E}-05$ & $2.38 \mathrm{E}-09$ & & $7.35 \mathrm{E}-05$ \\
\hline ecreational, Seep W4TF & & & & & \\
\hline
\end{tabular}


Produce/

\begin{tabular}{|c|c|c|c|c|}
\hline Land Use/Site/Contaminant & Ingestion & Fish & Inhalation & Total Risk \\
\hline SR-90 & 5.01E-05 & $5.20 E-03$ & & 5.25E-03 \\
\hline TRITIUM & 7.37E-05 & 8.49E-05 & & $1.59 \mathrm{E}-04$ \\
\hline Pathway Totals & $1.24 \mathrm{E}-04$ & $5.28 \mathrm{E}-03$ & & $5.41 \mathrm{E}-03$ \\
\hline \multicolumn{5}{|c|}{ Recreational, Seep W4TRIB-10, } \\
\hline SR-90 & 3.02E-05 & $3.13 E-03$ & & $3.16 \mathrm{E}-03$ \\
\hline TRITIUM & 8.45E-05 & 9.74E-05 & & 1.82E-04 \\
\hline Pathway Totals & 1.15E-04 & 3.23E-03 & & $3.35 \mathrm{E}-03$ \\
\hline \multicolumn{5}{|l|}{ Recreational, Seep W4TRIB-11 } \\
\hline$\overline{A S}$ & 3.11E-08 & & $2.95 E-08$ & $6.06 \mathrm{E}-08$ \\
\hline $\mathrm{BE}$ & 3.25E-08 & 3.74E-06 & 1.26E-06 & $5.03 E-06$ \\
\hline VINYL CHLORIDE & 1.43E-08 & 1.13E-07 & 4.06E-08 & 1.68E-07 \\
\hline CS-137 & 2.33E-07 & $5.38 E-04$ & & 5.38E-04 \\
\hline SR-90 & 4.71E-05 & $4.88 E-03$ & & 4.93E-03 \\
\hline TRITIUM & 9.45E-05 & 1.09E-04 & & 2.03E-04 \\
\hline Pathway Totals & $1.42 E-04$ & $5.53 \mathrm{E}-03$ & 1.33E-06 & $5.68 \mathrm{E}-03$ \\
\hline \multicolumn{5}{|l|}{ Recreational, ${ }^{\prime}$ Seep W4TRIB=12 } \\
\hline SR-90 & $2.29 E-05$ & 2.37E-03 & & $2.39 \mathrm{E}-03$ \\
\hline TRITIUM & 8.84E-07 & $1.02 \mathrm{E}-06$ & & $1.90 \mathrm{E}-06$ \\
\hline Pathway Totals & $2.38 \mathrm{E}-05$ & $2.37 \mathrm{E}-03$ & & $2.40 \mathrm{E}-03$ \\
\hline \multicolumn{5}{|l|}{ Recreational, Seep W4TRIB-2 } \\
\hline SR-90 & 5.21E-05 & $5.40 \mathrm{E}-03$ & & $5.45 \mathrm{E}-03$ \\
\hline TRITIUM & 7.69E-05 & 8.86E-05 & & 1.66E-04 \\
\hline Pathway Totals & 1.29E-04 & $5.49 \mathrm{E}-03$ & & $5.62 E-03$ \\
\hline \multicolumn{5}{|l|}{ Recreational ${ }_{r}$ Seep W4TRIB-3 } \\
\hline SR-90 & 3.35E-05 & $3.48 E-03$ & & 3.51E-03 \\
\hline TRITIUM & 8.41E-05 & $9.69 \mathrm{E}-05$ & & 1.81E-04 \\
\hline Pathway Totals & $1.18 \mathrm{E}-04$ & 3.57E-03 & & 3.69E-03 \\
\hline \multicolumn{5}{|c|}{ Recreational, Seep W4TRIB-4 } \\
\hline CS-137 & 5.22E-08 & $1.20 \mathrm{E}-04$ & & $1.20 \mathrm{E}-04$ \\
\hline SR-90 & 3.11E-05 & $3.22 \mathrm{E}-03$ & & $3.25 E-03$ \\
\hline TRITIUM & 8.74E-05 & $1.01 E-04$ & & $1.88 \mathrm{E}-04$ \\
\hline Pathway Totals & 1.19E-04 & $3.44 \mathrm{E}-03$ & & $3.56 \mathrm{E}-03$ \\
\hline \multicolumn{5}{|c|}{ Recreational, Seep W4TRIB $5 \ldots$} \\
\hline SR-90 & $3.65 \mathrm{E}-05$ & $3.78 \mathrm{E}-03$ & & $3.82 \mathrm{E}-03$ \\
\hline TRITIUM & 5.39E-05 & 6.21E-05 & & $1.16 \mathrm{E}-04$ \\
\hline Pathway Totals & 9.03E-05 & $3.84 \mathrm{E}-03$ & & 3.93E-03 \\
\hline \multicolumn{5}{|l|}{ Recreational; Seep:W4TRIB=6 } \\
\hline SR-90 & $2.84 E-05$ & $2.94 \mathrm{E}-03$ & & 2.97E-03 \\
\hline TRITIUM & 1.03E-04 & 1.19E-04 & & 2.22E-04 \\
\hline Pathway Totals & $1.31 E-04$ & 3.06E-03 & & $3.19 \mathrm{E}-03$ \\
\hline \multicolumn{5}{|l|}{ Recreational, Seep W4TRIB-7 } \\
\hline SR-90 & $6.90 E-05$ & $7.16 \mathrm{E}-03$ & & 7.23E-03 \\
\hline TRITIUM & 1.46E-04 & $1.68 \mathrm{E}-04$ & & 3.14E-04 \\
\hline Pathway Totals & $2.15 E-04$ & $7.33 E-03$ & & $7.54 \mathrm{E}-03$ \\
\hline \multicolumn{5}{|c|}{ Recreational, Seep W4TRIB:8 } \\
\hline SR-90 & 2.77E-05 & $E-03$ & & \\
\hline
\end{tabular}




\begin{tabular}{|c|c|c|c|c|c|}
\hline Land Use/Site/Contaminant & Inqestion & $\begin{array}{c}\text { Produce/ } \\
\text { Fish }\end{array}$ & Dermal & Inhalation & Total Risk \\
\hline TRITIUM & $1.03 E-04$ & $1.19 \mathrm{E}-04$ & & & $2.22 E-04$ \\
\hline Pathway Totals & 1.31E-04 & $2.99 \mathrm{E}-03$ & & & $3.12 \mathrm{E}-03$ \\
\hline Recreational, Seep W4TRIB-9 & & $\because$ & 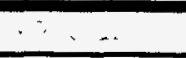 & $\therefore$ & \\
\hline SR-90 & $2.76 E-05$ & $2.87 E-03$ & & & $2.89 E-03$ \\
\hline TRITIUM & $1.08 E-04$ & 1.25E-04 & & & 2.33E-04 \\
\hline Pathway Totals & $1.36 \mathrm{E}-04$ & $2.99 \mathrm{E}-03$ & & & $3.13 E-03$ \\
\hline \multicolumn{6}{|l|}{ Recreational, Seep W6MS3 } \\
\hline SR-90 & $1.06 E-06$ & $1.10 \mathrm{E}-04$ & & & 1.11E-04 \\
\hline TRITIUM & 1.12E-05 & $1.29 \mathrm{E}-05$ & & & $2.40 \mathrm{E}-05$ \\
\hline Pathway Totals & $1.22 \mathrm{E}-05$ & $1.22 \mathrm{E}-04$ & & & $1.35 \mathrm{E}-04$ \\
\hline \multicolumn{6}{|l|}{ Recreational, Seep WAG4 MS1 } \\
\hline$\overline{B E}$ & $1.26 \mathrm{E}-07$ & 1.45E-05 & 4.89E-06 & & 1.95E-05 \\
\hline VINYL CHLORIDE & 1.43E-08 & 1.13E-07 & 4.06E-08 & & $1.68 \mathrm{E}-07$ \\
\hline TH-228 & $5.46 \mathrm{E}-08$ & $3.52 E-05$ & & & 3.53E-05 \\
\hline U-234 & 8.72E-08 & $1.00 \mathrm{E}-06$ & & & $1.09 \mathrm{E}-06$ \\
\hline$U-238$ & $5.44 E-08$ & 8.15E-06 & & & $8.20 E-06$ \\
\hline SR-90 & 4.03E-05 & 4.18E-03 & & & $4.22 E-03$ \\
\hline TRITIUM & 5.93E-05 & 6.83E-05 & & & 1.28E-04 \\
\hline Pathway Totals & $1.00 \mathrm{E}-04$ & $4.31 E-03$ & 4.93E-06 & & 4.42E-03 \\
\hline \multicolumn{6}{|l|}{ Recreational, Seep WAG4 T2A } \\
\hline$\overline{\mathrm{BE}}$ & 8.11E-08 & $9.35 \mathrm{E}-06$ & $3.15 E-06$ & & 1.26E-05 \\
\hline TRICHLOROETHENE & $8.30 \mathrm{E}-10$ & $3.76 \mathrm{E}-08$ & 3.44E-08 & & 7.28E-08 \\
\hline VINYL CHLORIDE & 7.17E-08 & $5.64 \mathrm{E}-07$ & 2.03E-07 & & 8.38E-07 \\
\hline CS-137 & 5.49E-07 & 1.27E-03 & & & $1.27 E-03$ \\
\hline SR-90 & 3.04E-05 & 3.15E-03 & & & 3.18E-03 \\
\hline TRITIUM & 4.57E-05 & 5.26E-05 & & & 9.83E-05 \\
\hline Pathway Totals & $7.68 \mathrm{E}-05$ & 4.48E-03 & $3.39 \mathrm{E}-06$ & & $4.56 \mathrm{E}-03$ \\
\hline \multicolumn{6}{|l|}{ Recreational, Seep WAG6 MS1. } \\
\hline $\mathrm{BE}$ & $9.74 E-08$ & $1.12 \mathrm{E}-05$ & $3.78 \mathrm{E}-06$ & & 1.51E-05 \\
\hline SR-90 & 2.49E-07 & $2.58 E-05$ & & & 2.61E-05 \\
\hline TRITIUM & 1.85E-06 & 2.13E-06 & & & $3.98 \mathrm{E}-06$ \\
\hline Pathway Totals & $2.19 E-06$ & $3.92 E-05$ & $3.78 E-06$ & & $4.51 \mathrm{E}-05$ \\
\hline \multicolumn{6}{|l|}{ Recreational, Seep WAG6 MS1-1 } \\
\hline$\overline{A S}$ & 2.26E-07 & & 2.14E-07 & & 4.41E-07 \\
\hline SR-90 & 8.30E-08 & 8.61E-06 & & & 8.69E-06 \\
\hline TRITIUM & 2.34E-06 & 2.70E-06 & & & $5.04 \mathrm{E}-06$ \\
\hline Pathway Totals & $2.65 \mathrm{E}-06$ & $1.13 E-05$ & $2.14 E-07$ & & $1.42 \mathrm{E}-05$ \\
\hline \multicolumn{6}{|l|}{ Recreational, Seep WAG6 MS2 } \\
\hline$\overline{\mathrm{BE}}$ & 8.11E-08 & $9.35 E-06$ & $3.15 E-06$ & & $1.26 \mathrm{E}-05$ \\
\hline 1,1,2-TRICHLOROETHANE & 2.15E-09 & 4.83E-08 & 8.66E-09 & & 5.91E-08 \\
\hline 1,2-DICHLOROETHANE & 3.43E-09 & $3.22 E-08$ & 7.06E-09 & & 4.27E-08 \\
\hline 1,2-DICHLOROPROPANE & 2.57E-09 & 5.76E-08 & 1.35E-08 & & 7.37E-08 \\
\hline BENZENE & 1.09E-09 & 2.93E-08 & 9.19E-09 & & 3.96E-08 \\
\hline CARBON TETRACHLORIDE & 4.91E-09 & 4.47E-07 & 6.44E-08 & & 5.16E-07 \\
\hline CHLOROFORM & 2.30E-10 & 5.17E-09 & 3.97E-09 & & 9.38E-09 \\
\hline DIBROMOCHLOROMETHANE & 3.17E-09 & 1.01E-07 & 8.00E-09 & & 1.12E-07 \\
\hline
\end{tabular}


Producel

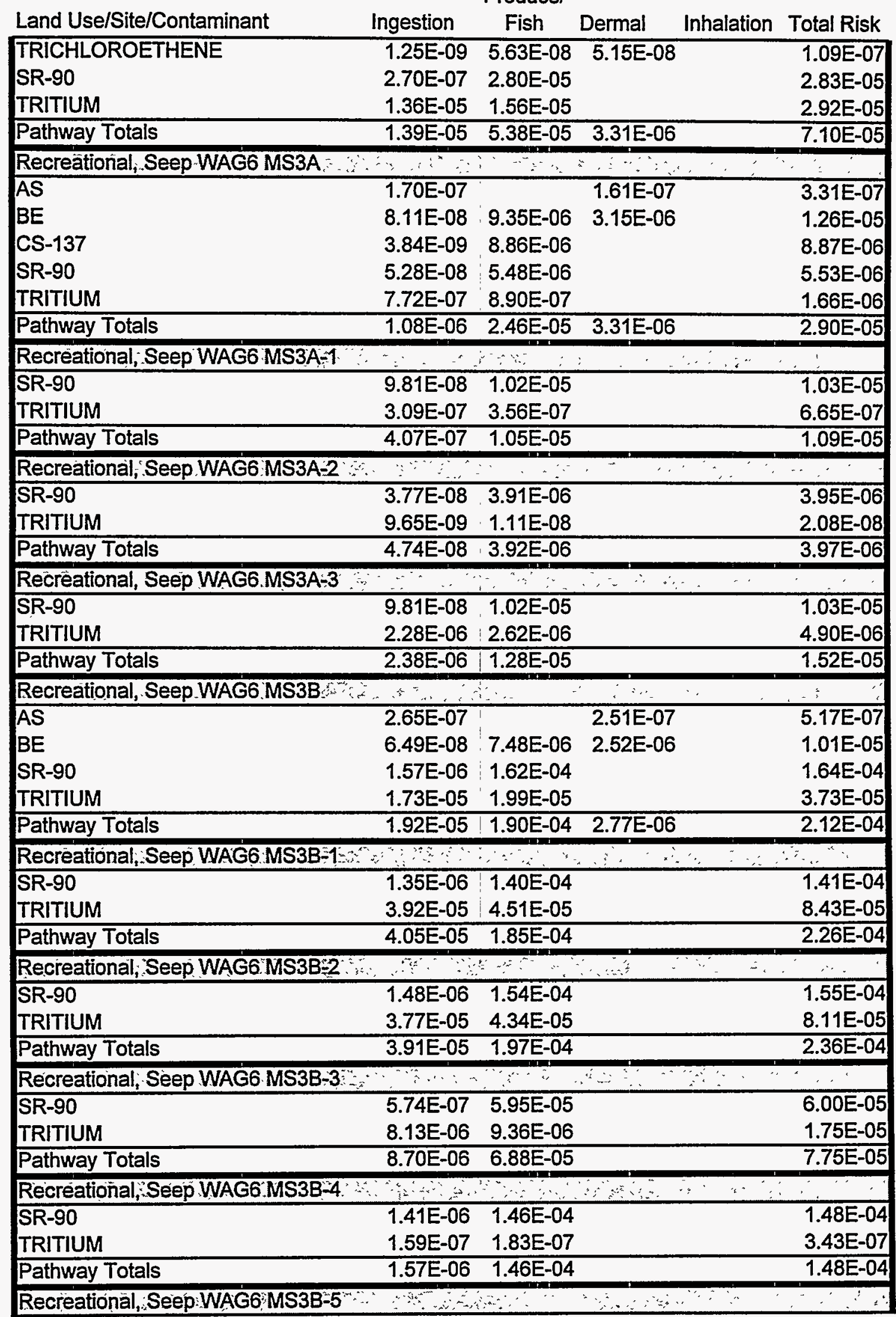




\begin{tabular}{|c|c|c|c|c|}
\hline & & Producel & & \\
\hline Land Use/Site/Contaminant & Ingestion & Fish Dermal & Inhalation & Total Risk \\
\hline SR-90 & $6.19 \mathrm{E}-07$ & $6.42 \mathrm{E}-05$ & & $6.48 E-05$ \\
\hline TRITIUM & 1.21E-07 & 1.39E-07 & & 2.60E-07 \\
\hline Pathway Totals & 7.39E-07 & $6.43 \mathrm{E}-05$ & & $6.50 \mathrm{E}-05$ \\
\hline Recreational, Seep WAG6 MS3B-6 & 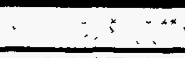 & & & \\
\hline SR-90 & $1.31 \mathrm{E}-06$ & $1.35 \mathrm{E}-04$ & & 1.37E-04 \\
\hline TRITIUM & 6.03E-07 & 6.95E-07 & & 1.30E-06 \\
\hline Pathway Totals & 1.91E-06 & $1.36 \mathrm{E}-04$ & & $1.38 \mathrm{E}-04$ \\
\hline Recreational, Seep.WC-1 & & & & \\
\hline CS-137 & $1.04 \mathrm{E}-07$ & $2.39 \mathrm{E}-04$ & & $2.39 E-04$ \\
\hline SR-90 & 1.38E-06 & 1.43E-04 & & 1.44E-04 \\
\hline TRITIUM & 9.16E-07 & $1.06 \mathrm{E}-06$ & & 1.97E-06 \\
\hline Pathway Totals & $2.40 E-06$ & $3.83 E-04$ & & $3.86 \mathrm{E}-04$ \\
\hline Recreational, Seep WC-10 & & & & \\
\hline SR-90 & 4.67E-07 & $4.84 E-05$ & & $4.89 \mathrm{E}-05$ \\
\hline TRITIUM & 2.05E-07 & 2.37E-07 & & 4.42E-07 \\
\hline Pathway Totals & $6.72 E-07$ & $4.86 \mathrm{E}-05$ & & 4.93E-05 \\
\hline Recreational, Seep WC-11 & & & & \\
\hline SR-90 & 5.62E-07 & 5.83E-05 & & 5.88E-05 \\
\hline TRITIUM & 2.15E-07 & 2.47E-07 & & 4.62E-07 \\
\hline Pathway Totals & 7.77E-07 & $5.85 E-05$ & & 5.93E-05 \\
\hline Recreational, Seep WC-12 & & & & \\
\hline SR-90 & $6.64 E-07$ & $6.88 \mathrm{E}-05$ & & 6.95E-05 \\
\hline TRITIUM & 2.25E-07 & $2.59 \mathrm{E}-07$ & & 4.83E-07 \\
\hline Pathway Totals & $8.89 E-07$ & $6.91 \mathrm{E}-05$ & & $7.00 \mathrm{E}-05$ \\
\hline Recreational, Seep WC-13 & & & & \\
\hline SR-90 & 5.57E-07 & 5.77E-05 & & 5.83E-05 \\
\hline TRITIUM & 1.91E-07 & $2.20 \mathrm{E}-07$ & & 4.10E-07 \\
\hline Pathway Totals & $7.48 \mathrm{E}-07$ & $5.80 \mathrm{E}-05$ & & 5.87E-05 \\
\hline Recreational, Seep WC-14 & & & & \\
\hline SR-90 & $8.15 \mathrm{E}-07$ & 8.45E-05 & & $8.53 E-05$ \\
\hline TRITIUM & 2.27E-07 & 2.61E-07 & & 4.88E-07 \\
\hline Pathway Totals & $1.04 \mathrm{E}-06$ & $8.48 E-05$ & & $8.58 \mathrm{E}-05$ \\
\hline Recreational, Seep WC-15 & & & & \\
\hline SR-90 & 7.28E-07 & 7.55E-05 & & 7.62E-05 \\
\hline TRITIUM & 1.16E-07 & 1.33E-07 & & 2.49E-07 \\
\hline Pathway Totals & 8.44E-07 & $7.56 \mathrm{E}-05$ & & 7.65E-05 \\
\hline Recreational, Seep WC-16 & 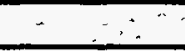 & & & \\
\hline SR-90 & $5.74 E-07$ & 5.95E-05 & & $6.00 \mathrm{E}-05$ \\
\hline TRITIUM & 1.93E-08 & $2.22 \mathrm{E}-08$ & & 4.15E-08 \\
\hline Pathway Totals & 5.93E-07 & $5.95 \mathrm{E}-05$ & & $6.01 \mathrm{E}-05$ \\
\hline Recreational, Seep WC-17 & & & & \\
\hline SR-90 & 4.44E-07 & 4.60E-05 & & $4.64 \mathrm{E}-05$ \\
\hline TRITIUM & $6.05 E-08$ & 6.97E-08 & & 1.30E-07 \\
\hline Pathway Totals & 5.04E-07 & $4.61 \mathrm{E}-05$ & & 4.66E-05 \\
\hline - & & & & \\
\hline-9 & & & & $E-05$ \\
\hline
\end{tabular}




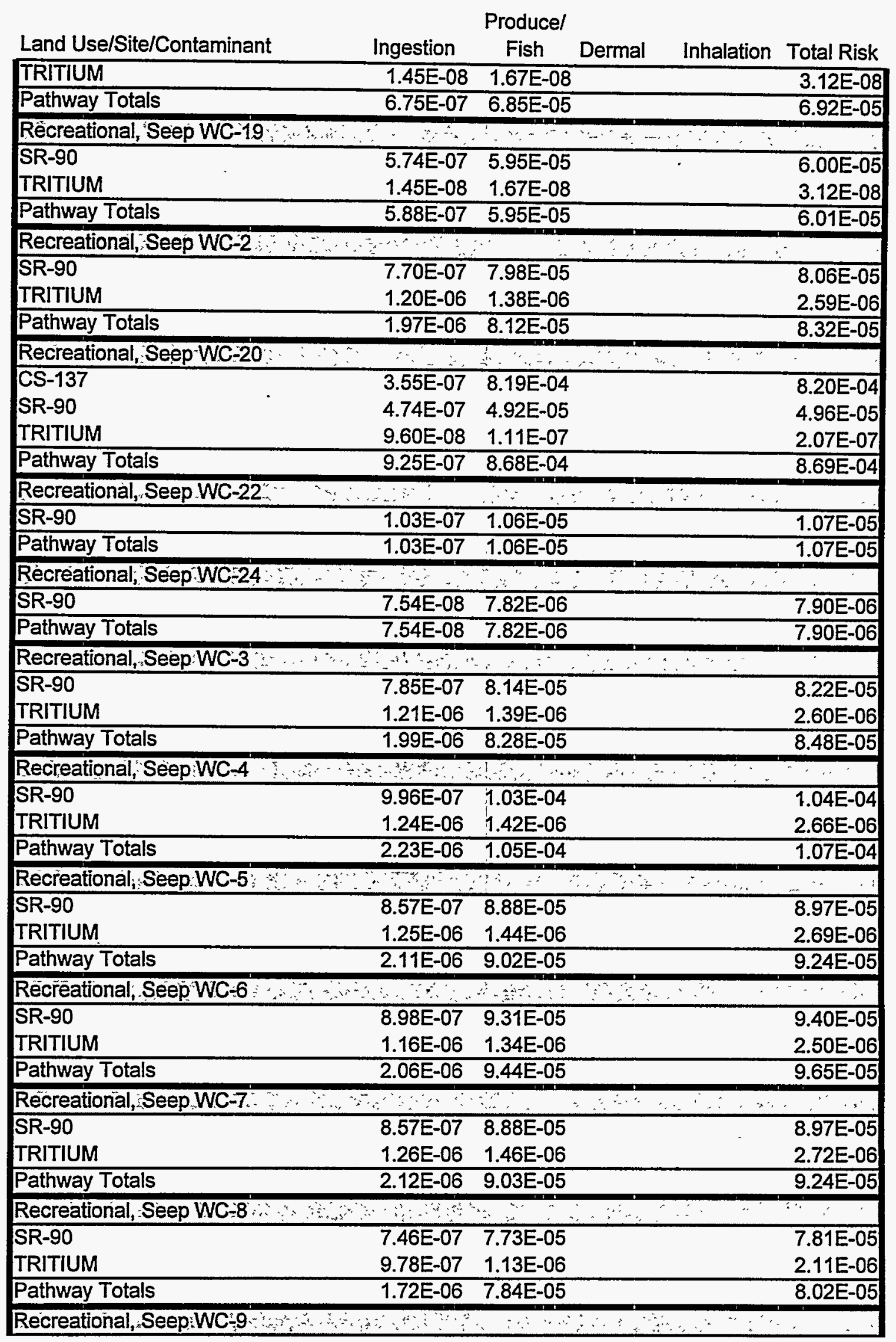


Producel

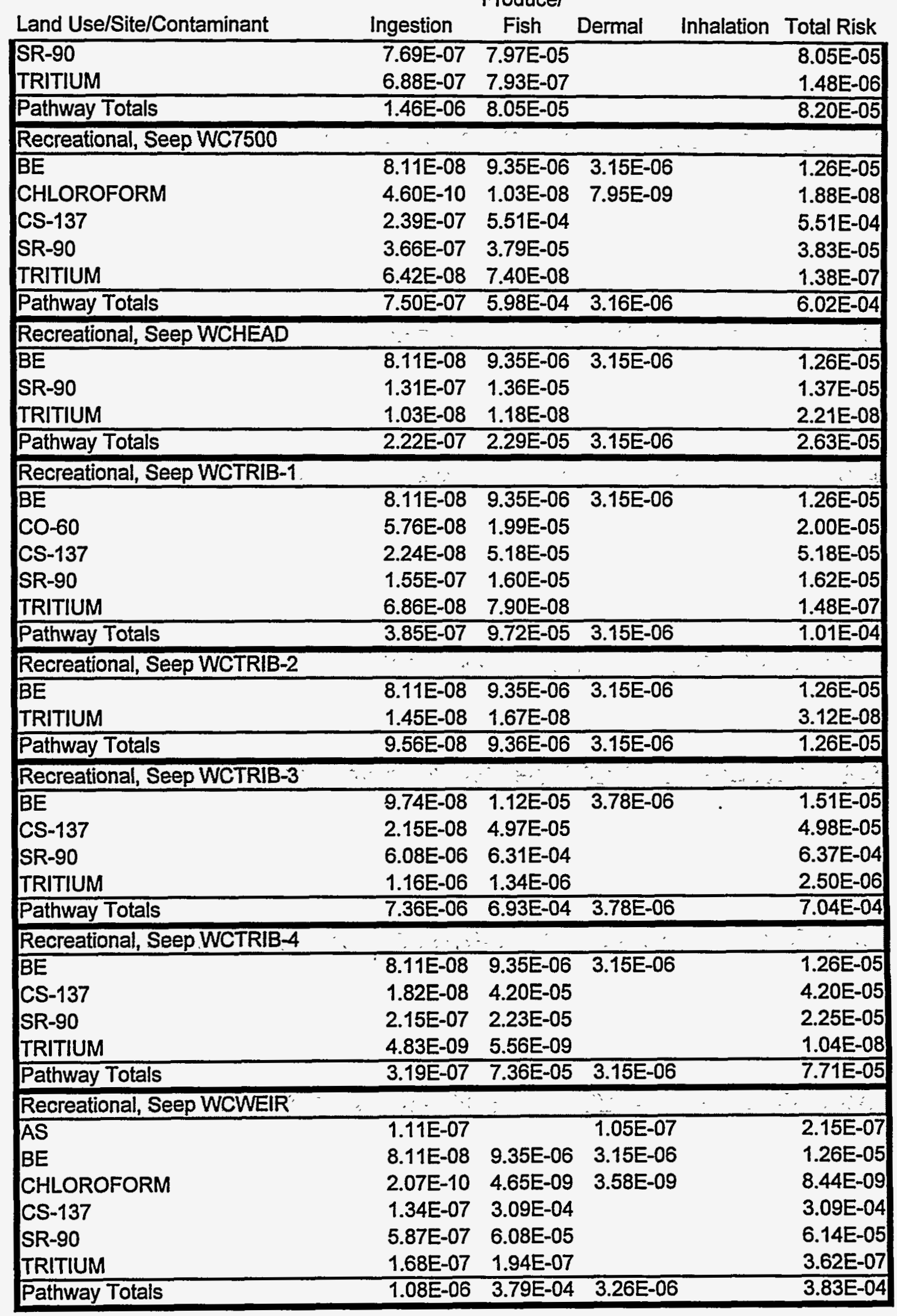




\begin{tabular}{|c|c|c|c|c|c|}
\hline Land Use/Site/Contaminant & Ingestion & $\begin{array}{l}\text { Producel } \\
\text { Fish }\end{array}$ & Dermal & Inhalation & Total Risk \\
\hline Recréational, Seep WEST SEEP & $\therefore \therefore \therefore$ & $\because$ & 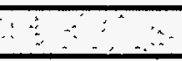 & $\therefore$ & $\because$ \\
\hline AS & $3.40 \mathrm{E}-08$ & & 3.22E-08 & & $6.61 \mathrm{E}-08$ \\
\hline$B E$ & $6.49 E-08$ & $7.48 \mathrm{E}-06$ & 2.52E-06 & & $1.01 E-05$ \\
\hline $\mathrm{CO}-60$ & 3.79E-08 & 1.31E-05 & & & 1.31E-05 \\
\hline SR-90 & 6.21E-07 & 6.44E-05 & & & $6.50 E-05$ \\
\hline TRITIUM & 2.26E-07 & 2.61E-07 & & & 4.87E-07 \\
\hline Pathway Totals & 9.84E-07 & $8.52 E-05$ & $2.55 \mathrm{E}-06$ & & $8.87 \mathrm{E}-05$ \\
\hline Recreational; Seep:WOCET: & $\because$ & $\because$ & & & \\
\hline SR-90 & 8.98E-08 & 9.31E-06 & & & $9.40 \mathrm{E}-06$ \\
\hline TRITIUM & 5.55E-09 & 6.39E-09 & & & 1.19E-08 \\
\hline Pathway Totals & $9.54 E-08$ & $9.32 E-06$ & & & 9.41E-06 \\
\hline Recreational, Seep WOD : & $\therefore \quad \cdots$ & $\because \cdots$ & $\cdots$ & & \\
\hline$\overline{A S}$ & $3.40 \mathrm{E}-08$ & & $3.22 E-08$ & & $6.61 E-08$ \\
\hline $\mathrm{BE}$ & 8.11E-08 & $9.35 \mathrm{E}-06$ & 3.15E-06 & & 1.26E-05 \\
\hline CHLOROFORM & $9.21 E-11$ & 2.07E-09 & 1.59E-09 & & $3.75 \mathrm{E}-09$ \\
\hline CS-137 & $1.24 \mathrm{E}-07$ & 2.86E-04 & & & 2.86E-04 \\
\hline SR-90 & 7.74E-07 & 8.02E-05 & & & 8.10E-05 \\
\hline TRITIUM & 8.77E-07 & 1.01E-06 & & & 1.89E-06 \\
\hline Pathway Totals & 1.89E-06 & $3.76 \mathrm{E}-04$ & 3.18E-06 & & 3.81E-04 \\
\hline Recreational, Sëep WS-1 & $\therefore \times$ & 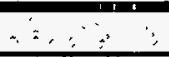 & $\because$ & & $\because$ \\
\hline SR-90 & $6.73 E-07$ & 6.97E-05 & & & 7.04E-05 \\
\hline TRITIUM & 1.14E-07 & $1.32 E-07$ & & & 2.46E-07 \\
\hline Pathway Totals & 7.87E-07 & $6.99 \mathrm{E}-05$ & & & 7.07E-05 \\
\hline \multicolumn{6}{|l|}{ Recreational, Seep WS-2 } \\
\hline CO-60 & $1.23 \mathrm{E}-07$ & $4.25 E-05$ & & & $4.26 \mathrm{E}-05$ \\
\hline SR-90 & 2.13E-06 & 2.21E-04 & & & 2.23E-04 \\
\hline TRITIUM & 1.68E-07 & $1.93 E-07$ & & & 3.61E-07 \\
\hline Pathway Totals & $2.42 E-06$ & $2.64 E-04$ & & & $2.66 \mathrm{E}-04$ \\
\hline \multicolumn{6}{|l|}{ Recreational, Seep WS:3 } \\
\hline SR-90 & 8.60E-07 & 8.91E-05 & & & $9.00 E-05$ \\
\hline TRITIUM & 5.29E-08 & $6.09 \mathrm{E}-08$ & & & 1.14E-07 \\
\hline Pathway Totals & $9.13 E-07$ & $8.92 E-05$ & & & 9.01E-05 \\
\hline \multicolumn{6}{|l|}{ Recreational, Seep WSTRIB=1: } \\
\hline$\overline{\mathrm{BE}}$ & 4.87E-08 & 5.61E-06 & $1.89 E-06$ & & $7.55 \mathrm{E}-06$ \\
\hline $\mathrm{CO}-60$ & 5.26E-08 & 1.82E-05 & & & 1.82E-05 \\
\hline CS-137 & 9.81E-09 & 2.27E-05 & & & 2.27E-05 \\
\hline SR-90 & 8.63E-07 & 8.95E-05 & & & 9.04E-05 \\
\hline TRITIUM & 2.12E-07 & 2.44E-07 & & & 4.55E-07 \\
\hline Pathway Totals & 1.19E-06 & $1.36 \mathrm{E}-04$ & 1.89E-06 & & 1.39E-04 \\
\hline \multicolumn{6}{|c|}{ Résidential, Seep,05:SP014, } \\
\hline 1,1-DICHLOROETHENE & $7.05 \mathrm{E}-05$ & & $1.52 \mathrm{E}-06$ & $7.05 \mathrm{E}-04$ & $7.76 \mathrm{E}-04$ \\
\hline 1,2-DICHLOROETHANE & 6.41E-06 & & 8.24E-08 & 3.21E-05 & 3.85E-05 \\
\hline BENZENE & 6.81E-07 & & $3.58 E-08$ & 3.41E-06 & $4.12 E-06$ \\
\hline CHLOROFORM & 1.43E-07 & & 1.55E-08 & 9.51E-06 & 9.67E-06 \\
\hline TETRACHLOROETHENE & 1.77E-05 & & 1.59E-05 & $3.41 E-06$ & $3.70 E-05$ \\
\hline TRICHLOROETHENE & 1.15E-05 & & 2.97E-06 & 3.14E-05 & $4.58 E-05$ \\
\hline
\end{tabular}




\begin{tabular}{|c|c|c|c|c|c|}
\hline Land Use/Site/Contaminant & Ingestion & $\begin{array}{l}\text { roduce } \\
\text { Fish }\end{array}$ & Dermal & Inhalation & Total Risk \\
\hline VINYL CHLORIDE & $1.63 E-03$ & & $2.88 \mathrm{E}-05$ & $1.29 \mathrm{E}-03$ & $2.94 \mathrm{E}-03$ \\
\hline$C-14$ & 1.97E-05 & & & & $1.97 E-05$ \\
\hline SR-90 & 7.16E-04 & & & & 7.16E-04 \\
\hline TC-99 & $2.60 \mathrm{E}-06$ & & & & 2.60E-06 \\
\hline TRITIUM & 3.41E-03 & & & 5.34E-04 & $3.95 E-03$ \\
\hline$U-233 / 234$ & $1.03 E-06$ & & & & 1.03E-06 \\
\hline Pathway Totals & 5.89E-03 & & $4.93 \mathrm{E}-05$ & $2.60 E-03$ & $8.54 \mathrm{E}-03$ \\
\hline \multicolumn{6}{|l|}{ Residential, Seep 05. SP015 } \\
\hline TRICHLOROETHENE & $2.58 \mathrm{E}-07$ & & $6.68 \mathrm{E}-08$ & 7.05E-07 & $1.03 \mathrm{E}-06$ \\
\hline VINYL CHLORIDE & 4.46E-05 & & 7.90E-07 & $3.52 E-05$ & 8.06E-05 \\
\hline RA-226 & $3.85 E-06$ & & & & 3.85E-06 \\
\hline RA-228 & $5.73 E-04$ & & & & 5.73E-04 \\
\hline SR-90 & 2.82E-04 & & & & 2.82E-04 \\
\hline TH-234 & 4.46E-04 & & & & $4.46 E-04$ \\
\hline TRITIUM & 4.65E-04 & & & 7.29E-05 & 5.38E-04 \\
\hline U-233/234 & $1.03 E-03$ & & & & 1.03E-03 \\
\hline$U-235$ & 7.99E-05 & & & & 7.99E-05 \\
\hline$U-238$ & 2.47E-03 & & & & 2.47E-03 \\
\hline Pathway Totals & 5.39E-03 & & 8.57E-07 & $1.09 E-04$ & $5.50 E-03$ \\
\hline \multicolumn{6}{|l|}{ Residential, Seep 05.SP016 } \\
\hline SR-90 & 3.40E-06 & & & & $3.40 E-06$ \\
\hline TRITIUM & $1.95 \mathrm{E}-06$ & & & 3.05E-07 & 2.26E-06 \\
\hline Pathway Totals & $5.35 \mathrm{E}-06$ & & & 3.05E-07 & 5.66E-06 \\
\hline \multicolumn{6}{|l|}{ Residential, Seep 05.SP017 } \\
\hline AS & $6.34 E-05$ & & $3.75 \mathrm{E}-07$ & & $6.38 \mathrm{E}-05$ \\
\hline VINYL CHLORIDE & 4.46E-05 & & 7.90E-07 & 3.52E-05 & 8.06E-05 \\
\hline C-14 & 3.03E-06 & & & & $3.03 E-06$ \\
\hline CS-137 & 8.23E-06 & & & & 8.23E-06 \\
\hline SR-90 & $3.68 E-03$ & & & & $3.68 \mathrm{E}-03$ \\
\hline TC-99 & 1.19E-05 & & & & 1.19E-05 \\
\hline TRITIUM & 8.39E-03 & & & $1.31 E-03$ & $9.70 E-03$ \\
\hline Pathway Totals & $1.21 E-02$ & & 1.17E-06 & $1.35 E-03$ & 1.35E-02 \\
\hline \multicolumn{6}{|l|}{ Residential, Seep 05.SW001 } \\
\hline$\overline{P B-212}$ & 8.00E-06 & & & & 8.00E-06 \\
\hline PU-238 & 1.69E-06 & & & & 1.69E-06 \\
\hline SR-90 & 3.51E-05 & & & & 3.51E-05 \\
\hline TH-228 & 2.78E-06 & & & & 2.78E-06 \\
\hline TH-230 & 3.58E-06 & & & & $3.58 E-06$ \\
\hline TRITIUM & $1.60 \mathrm{E}-04$ & & & 2.50E-05 & $1.85 E-04$ \\
\hline$U-233 / 234$ & 4.44E-05 & & & & 4.44E-05 \\
\hline$U-235$ & 1.68E-06 & & & & $1.68 \mathrm{E}-06$ \\
\hline$U-235 / 236$ & 2.43E-06 & & & & 2.43E-06 \\
\hline$U-238$ & $9.86 \mathrm{E}-05$ & & & & 9.86E-05 \\
\hline Pathway Totals & 3.58E-04 & & & $2.50 E-05$ & $3.83 E-04$ \\
\hline \multicolumn{6}{|l|}{ Residential, Seep 05. SW002 } \\
\hline$\overline{A S}$ & $2.16 E-05$ & & & & $2.18 \mathrm{E}-0$ \\
\hline
\end{tabular}




\begin{tabular}{|c|c|c|c|c|c|}
\hline \multirow{2}{*}{ Land Use/Site/Contaminant } & \multicolumn{3}{|c|}{ Producel } & \multirow{2}{*}{ Inhalation } & \multirow{2}{*}{ Total Risk } \\
\hline & ingestion & risn & Dermal & & \\
\hline BIS(2-ETHYLHEXYL) PHTHALATE & $9.86 \mathrm{E}-07$ & & $2.95 \mathrm{E}-07$ & & 1.28E-06 \\
\hline$A M-241$ & 6.41E-05 & & & & 6.41E-05 \\
\hline C-14 & 6.48E-06 & & & & $6.48 E-06$ \\
\hline PU-238 & 1.18E-04 & & & & 1.18E-04 \\
\hline PU-239/240 & $1.32 E-06$ & & & & 1.32E-06 \\
\hline RA-226 & $1.50 \mathrm{E}-06$ & & & & 1.50E-06 \\
\hline RA-228 & 8.41E-03 & & & & 8.41E-03 \\
\hline SR-90 & 2.92E-03 & & & & 2.92E-03 \\
\hline TC-99 & 1.11E-06 & & & & 1.11E-06 \\
\hline TH-228 & 5.76E-06 & & & & 5.76E-06 \\
\hline TH-230 & 6.87E-06 & & & & $6.87 E-06$ \\
\hline TRITIUM & 1.61E-02 & & & 2.54E-03 & $1.86 \mathrm{E}-02$ \\
\hline$U-233 / 234$ & 5.50E-06 & & & & 5.50E-06 \\
\hline U-238 & 1.14E-06 & & & & 1.14E-06 \\
\hline Pathway Totals & $2.74 \mathrm{E}-02$ & & 4.23E-07 & $2.54 E-03$ & 2.99E-02 \\
\hline \multicolumn{6}{|c|}{ Résidential, Seep 05.SW003 } \\
\hline RA-226 & 1.35E-06 & & & & $1.35 \mathrm{E}-06$ \\
\hline SR-90 & 5.62E-05 & & & & 5.62E-05 \\
\hline TH-228 & 2.50E-06 & & & & 2.50E-06 \\
\hline TRITIUM & 4.03E-06 & & & $6.30 \mathrm{E}-07$ & 4.66E-06 \\
\hline Pathway Totals & $6.41 \mathrm{E}-05$ & & & $6.30 \mathrm{E}-07$ & 6.47E-05 \\
\hline \multicolumn{6}{|l|}{ Residential; Seep 05.SW004: } \\
\hline AM-241 & 3.55E-05 & & & & 3.55E-05 \\
\hline $\mathrm{CA}-45$ & 4.20E-05 & & & & 4.20E-05 \\
\hline CM-243/244 & 2.76E-06 & & & & 2.76E-06 \\
\hline SR-90 & $1.64 \mathrm{E}-03$ & & & & 1.64E-03 \\
\hline TH-228 & 8.10E-06 & & & & 8.10E-06 \\
\hline TH-230 & 7.04E-06 & & & & 7.04E-06 \\
\hline TH-232 & 2.14E-06 & & & & 2.14E-06 \\
\hline TRITIUM & 1.19E-06 & & & 1.87E-07 & 1.38E-06 \\
\hline Pathway Totals & 1.74E-03 & & & 1.87E-07 & 1.74E-03 \\
\hline Residential, Seep 05.SW005 & $\because y+\ldots$ & & & $\therefore$ & m \\
\hline BIS(2-ETHYLHEXYL) PHTHALATE & 5.92E-06 & & 1.77E-06 & & $7.69 \mathrm{E}-06$ \\
\hline RA-228 & 2.66E-05 & & & & 2.66E-05 \\
\hline SR-90 & 4.05E-05 & & & & 4.05E-05 \\
\hline TH-228 & 5.01E-06 & & & & 5.01E-06 \\
\hline TH-230 & 6.49E-06 & & & & $6.49 \mathrm{E}-06$ \\
\hline TH-232 & $1.20 \mathrm{E}-06$ & & & & 1.20E-06 \\
\hline TRITIUM & 3.35E-05 & & & 5.24E-06 & 3.87E-05 \\
\hline U-238 & 1.21E-06 & & & & 1.21E-06 \\
\hline Pathway Totals & $1.20 E-04$ & & 1.77E-06 & 5.24E-06 & 1.27E-04 \\
\hline \multicolumn{6}{|c|}{ Residential, Seep 05:SW006 } \\
\hline AM-241 & 3.93E-05 & & & & 3.93E-05 \\
\hline C-14 & 2.18E-05 & & & & 2.18E-05 \\
\hline $\mathrm{CA}-45$ & 7.21E-06 & & & & 7.21E-06 \\
\hline CM-243/244 & 1.29E-06 & & & & 1.29E-06 \\
\hline PU-238 & 2.59E-05 & & & & 2.59E-05 \\
\hline
\end{tabular}




\begin{tabular}{|c|c|c|c|c|c|}
\hline \multirow[b]{2}{*}{ Land Use/Site/Contaminant } & \multicolumn{3}{|c|}{ Producel } & \multirow[b]{2}{*}{ Inhalation } & \multirow[b]{2}{*}{ Total Risk } \\
\hline & Ingestion & & Dermal & & \\
\hline SR-90 & $7.43 E-04$ & & & & 7.43E-04 \\
\hline TH-228 & 5.89E-06 & & & & 5.89E-06 \\
\hline TH-230 & 2.55E-06 & & & & 2.55E-06 \\
\hline TRITIUM & $1.98 E-03$ & & & $3.10 \mathrm{E}-04$ & 2.29E-03 \\
\hline $\mathrm{U}-238$ & $1.48 \mathrm{E}-06$ & & & & $1.48 E-06$ \\
\hline Pathway Totals & $2.83 E-03$ & & & $3.10 \mathrm{E}-04$ & $3.14 E-03$ \\
\hline \multicolumn{6}{|l|}{ Residential, Seep 5NNT } \\
\hline $\mathrm{BE}$ & $2.02 E-05$ & & $4.90 E-06$ & & 2.51E-05 \\
\hline METHYLENE CHLORIDE & $1.14 E-06$ & & $1.31 E-08$ & 1.26E-06 & 2.41E-06 \\
\hline SR-90 & 2.11E-05 & & & & 2.11E-05 \\
\hline TRITIUM & 3.00E-06 & & & 4.70E-07 & 3.47E-06 \\
\hline Pathway Totals & 4.55E-05 & & 4.91E-06 & 1.73E-06 & $5.21 \mathrm{E}-05$ \\
\hline \multicolumn{6}{|l|}{ Residential, Seep 5NST } \\
\hline$\overline{B E}$ & 3.03E-05 & & 7.35E-06 & & 3.76E-05 \\
\hline SR-90 & $9.04 E-05$ & & & & 9.04E-05 \\
\hline TRITIUM & 1.16E-04 & & & 1.81E-05 & $1.34 E-04$ \\
\hline Pathway Totals & $2.36 E-04$ & & $7.35 \mathrm{E}-06$ & 1.81E-05 & $2.62 \mathrm{E}-04$ \\
\hline \multicolumn{6}{|l|}{ Residential, Seep 5NW-1 } \\
\hline$\overline{\mathrm{BE}}$ & $2.52 E-05$ & & $6.12 E-06$ & & 3.14E-05 \\
\hline SR-90 & 2.11E-05 & & & & 2.11E-05 \\
\hline TRITIUM & 6.01E-06 & & & 9.41E-07 & $6.95 E-06$ \\
\hline Pathway Totals & 5.24E-05 & & $6.12 \mathrm{E}-06$ & $9.41 \mathrm{E}-07$ & 5.94E-05 \\
\hline \multicolumn{6}{|l|}{ Residential, Seep 5NW:2 } \\
\hline$\overline{B E}$ & 2.52E-05 & & $6.12 \mathrm{E}-06$ & & $3.14 \mathrm{E}-05$ \\
\hline CS-137 & 1.68E-05 & & & & $1.68 \mathrm{E}-05$ \\
\hline SR-90 & $1.64 \mathrm{E}-05$ & & & & $1.64 E-05$ \\
\hline TH-232 & 2.00E-05 & & & & 2.00E-05 \\
\hline TRITIUM & 2.85E-05 & & & 4.47E-06 & 3.30E-05 \\
\hline$U-238$ & 1.26E-06 & & & & 1.26E-06 \\
\hline Pathway Totals & $1.08 \mathrm{E}-04$ & & $6.12 \mathrm{E}-06$ & 4.47E-06 & $1.19 E-04$ \\
\hline \multicolumn{6}{|l|}{ Residential, Seep BTT } \\
\hline$\overline{B E}$ & 3.07E-05 & & 7.44E-06 & & 3.81E-05 \\
\hline PU-239 & $2.32 E-06$ & & & & 2.32E-06 \\
\hline TH-228 & $1.55 \mathrm{E}-05$ & & & & 1.55E-05 \\
\hline U-232 & 5.25E-06 & & & & 5.25E-06 \\
\hline$U-234$ & 2.02E-04 & & & & 2.02E-04 \\
\hline U-235 & 6.89E-06 & & & & $6.89 E-06$ \\
\hline$U-238$ & 1.46E-04 & & & & $1.46 E-04$ \\
\hline CS-137 & 4.01E-04 & & & & 4.01E-04 \\
\hline SR-90 & 2.74E-02 & & & & 2.74E-02 \\
\hline TRITIUM & 5.34E-05 & & & 8.36E-06 & 6.17E-05 \\
\hline Pathway Totals & 2.82E-02 & & 7.44E-06 & 8.36E-06 & $2.82 E-02$ \\
\hline \multicolumn{6}{|l|}{ Residential, Seep EAST SEEP } \\
\hline AS & 6.11E-05 & & 3.61E-07 & & $6.14 \mathrm{E}-05$ \\
\hline$B E$ & 2.52E-05 & & 6.12E-06 & & 3.14E-05 \\
\hline CO-60 & 7.16E-05 & & & & 7.16E-05 \\
\hline
\end{tabular}




\begin{tabular}{|c|c|c|c|c|c|}
\hline \multirow[b]{2}{*}{ Land Use/Site/Contaminant } & \multicolumn{3}{|c|}{ Produce/ } & \multirow[b]{2}{*}{ Inhalation } & \multirow[b]{2}{*}{ Total Risk } \\
\hline & Ingestion & Fish & Dermal & & \\
\hline SR-90 & 4.62E-05 & & & & $4.62 \mathrm{E}-05$ \\
\hline TRITIUM & 4.50E-05 & & & 7.05E-06 & 5.21E-05 \\
\hline Pathway Totals & $2.49 E-04$ & & $6.48 \mathrm{E}-06$ & 7.05E-06 & $2.63 E-04$ \\
\hline Residential, Seep FG-1 & $\because \ldots$ & & & & . \\
\hline SR-90 & $4.80 \mathrm{E}-04$ & & & & $4.80 \mathrm{E}-04$ \\
\hline Pathway Totals & $4.80 E-04$ & & & & $4.80 E-04$ \\
\hline \multicolumn{6}{|c|}{ Residential; Seep'FIFTH CREEK } \\
\hline CS-137 & 1.53E-06 & & & & $1.53 E-06$ \\
\hline SR-90 & $1.14 \mathrm{E}-04$ & & & & 1.14E-04 \\
\hline TRITIUM & 1.05E-05 & & & 1.65E-06 & 1.22E-05 \\
\hline Pathway Totals & $1.26 \mathrm{E}-04$ & & & 1.65E-06 & $1.28 \mathrm{E}-04$ \\
\hline \multicolumn{6}{|c|}{ Residential; Seèp-FIRST CREEK } \\
\hline $\mathrm{BE}$ & $6.56 \mathrm{E}-06$ & & $1.59 E-06$ & & $8.16 \mathrm{E}-06$ \\
\hline CHLOROFORM & 2.86E-08 & & 3.09E-09 & $1.90 \mathrm{E}-06$ & 1.93E-06 \\
\hline SR-90 & 4.40E-04 & & & & 4.40E-04 \\
\hline TRITIUM & 2.86E-06 & & & 4.47E-07 & $3.30 \mathrm{E}-06$ \\
\hline Pathway Totals & 4.49E-04 & & 1.59E-06 & $2.35 E-06$ & 4.53E-04 \\
\hline \multicolumn{6}{|c|}{ Residential, Seep FRENCHLDR S } \\
\hline 1,1-DICHLOROETHENE & 1.41E-06 & & 3.04E-08 & 1.41E-05 & $1.55 \mathrm{E}-05$ \\
\hline 1,2-DICHLOROETHANE & 6.41E-07 & & 8.24E-09 & 3.21E-06 & $3.85 \mathrm{E}-06$ \\
\hline CHLOROFORM & 2.86E-08 & & 3.09E-09 & $1.90 \mathrm{E}-06$ & 1.93E-06 \\
\hline TETRACHLOROETHENE & 6.04E-05 & & 5.42E-05 & 1.16E-05 & 1.26E-04 \\
\hline TRICHLOROETHENE & 1.29E-04 & & 3.34E-05 & 3.52E-04 & 5.15E-04 \\
\hline VINYL CHLORIDE & 4.46E-05 & & 7.90E-07 & 3.52E-05 & 8.06E-05 \\
\hline Pathway Totals & $2.36 \mathrm{E}-04$ & & 8.85E-05 & 4.18E-04 & $7.43 \mathrm{E}-04$ \\
\hline \multicolumn{6}{|c|}{ Residential, Seep FRENCH'DRAIN,$\ldots \ldots$} \\
\hline SR-90 & 7.04E-06 & & & & 7.04E-06 \\
\hline TRITIUM & 8.76E-03 & & & 1.37E-03 & 1.01E-02 \\
\hline Pathway Totals & 8.77E-03 & & & 1.37E-03 & 1.01E-02 \\
\hline \multicolumn{6}{|c|}{ Residential, Seep HRT 10 , } \\
\hline SR-90 & 4.30E-04 & & & & $4.30 \mathrm{E}-04$ \\
\hline Pathway Totals & 4.30E-04 & & & & 4.30E-04 \\
\hline \multicolumn{6}{|c|}{ Residential, Seep HRT-1A } \\
\hline SR-90 & 1.45E-03 & & & & 1.45E-03 \\
\hline TRITIUM & 2.84E-03 & & & 4.44E-04 & $3.28 \mathrm{E}-03$ \\
\hline Pathway Totals & 4.29E-03 & & & 4.44E-04 & 4.73E-03 \\
\hline \multicolumn{6}{|c|}{ Residential, Seep HRT-1B } \\
\hline SR-90 & 8:81E-04 & & & & 8.81E-04 \\
\hline TRITIUM & 2.48E-03 & & & 3.88E-04 & 2.86E-03 \\
\hline Pathway Totals & 3.36E-03 & & & 3.88E-04 & 3.74E-03 \\
\hline \multicolumn{6}{|c|}{ Residential; Seep HRT-1C, } \\
\hline SR-90 & 2.73E-03 & & & & $2.73 \mathrm{E}-03$ \\
\hline TRITIUM & 4.68E-03 & & & 7.33E-04 & 5.41E-03 \\
\hline Pathway Totals & 7.41E-03 & & & 7.33E-04 & $8.14 \mathrm{E}-03$ \\
\hline \multicolumn{6}{|c|}{ Residential, Seep HRT-1D, } \\
\hline SR-90 & 2. & & & & \\
\hline
\end{tabular}




\begin{tabular}{|c|c|c|c|c|c|}
\hline Land Use/Site/Contaminant & Ingestion & $\begin{array}{l}\text { Produce } \\
\text { Fish }\end{array}$ & Dermal & Inhalation & Total Risk \\
\hline TRITIUM & 9.17E-03 & & & $1.44 \mathrm{E}-03$ & $1.05 E-02$ \\
\hline Pathway Totals & 1.12E-02 & & & $1.44 E-03$ & $1.26 \mathrm{E}-02$ \\
\hline \multicolumn{6}{|l|}{ Residential, Seep HRT-2 } \\
\hline SR-90 & 1.69E-03 & & & & $1.69 \mathrm{E}-03$ \\
\hline TRITIUM & 2.81E-03 & & & 4.40E-04 & $3.25 \mathrm{E}-03$ \\
\hline Pathway Totals & 4.50E-03 & & & $4.40 \mathrm{E}-04$ & $4.94 \mathrm{E}-03$ \\
\hline \multicolumn{6}{|l|}{ Residential, Seep HRT-2A } \\
\hline SR-90 & $2.32 E-03$ & & & & $2.32 \mathrm{E}-03$ \\
\hline TRITIUM & 2.29E-03 & & & $3.59 \mathrm{E}-04$ & 2.65E-03 \\
\hline Pathway Totals & 4.61E-03 & & & 3.59E-04 & 4.97E-03 \\
\hline \multicolumn{6}{|l|}{ Residential, Seep HRT-3 } \\
\hline AS & $9.69 \mathrm{E}-06$ & & $5.73 E-08$ & & $9.74 \mathrm{E}-06$ \\
\hline $\mathrm{BE}$ & 1.41E-05 & & 3.43E-06 & & $1.76 \mathrm{E}-05$ \\
\hline SR-90 & 1.46E-03 & & & & $1.46 \mathrm{E}-03$ \\
\hline TRITIUM & 1.93E-06 & & & $3.02 E-07$ & 2.23E-06 \\
\hline Pathway Totals & 1.49E-03 & & $3.49 E-06$ & $3.02 \mathrm{E}-07$ & $1.49 \mathrm{E}-03$ \\
\hline \multicolumn{6}{|l|}{ Residential, Seep HRT-4 } \\
\hline SR-90 & $1.48 E-03$ & & & & $1.48 \mathrm{E}-03$ \\
\hline TRITIUM & $1.50 E-06$ & & & 2.35E-07 & $1.74 E-06$ \\
\hline Pathway Totals & $1.48 \mathrm{E}-03$ & & & $2.35 \mathrm{E}-07$ & $1.48 \mathrm{E}-03$ \\
\hline \multicolumn{6}{|l|}{ Residential, Seep HRT-5 } \\
\hline SR-90 & $2.11 \mathrm{E}-03$ & & & & $2.11 \mathrm{E}-03$ \\
\hline Pathway Totals & 2.11E-03 & & & & $2.11 \mathrm{E}-03$ \\
\hline \multicolumn{6}{|l|}{ Residential, Seep HRT-6 } \\
\hline SR-90 & 1.41E-03 & & & & 1.41E-03 \\
\hline Pathway Totals & $1.41 \mathrm{E}-03$ & & & & $1.41 \mathrm{E}-03$ \\
\hline \multicolumn{6}{|l|}{ Residential, Seep HRT-7 } \\
\hline SR-90 & $9.20 \mathrm{E}-04$ & & & & $9.20 \mathrm{E}-04$ \\
\hline Pathway Totals & $9.20 E-04$ & & & & $9.20 E-04$ \\
\hline \multicolumn{6}{|l|}{ Residential, Seep HRT-8 } \\
\hline SR-90 & $5.20 \mathrm{E}-03$ & & & & $5.20 \mathrm{E}-03$ \\
\hline Pathway Totals & $5.20 \mathrm{E}-03$ & & & & $5.20 \mathrm{E}-03$ \\
\hline \multicolumn{6}{|l|}{ Residential, Seep HRT-9 } \\
\hline SR-90 & $2.30 E-03$ & & & & $2.30 E-03$ \\
\hline Pathway Totals & $2.30 \mathrm{E}-03$ & & & & 2.30E-03 \\
\hline \multicolumn{6}{|l|}{ Residential, Seep MB-1 } \\
\hline AS & $3.17 \mathrm{E}-05$ & & $1.88 \mathrm{E}-07$ & & 3.19E-05 \\
\hline $\mathrm{BE}$ & 5.86E-05 & & 1.42E-05 & & 7.29E-05 \\
\hline SR-90 & 1.10E-03 & & & & $1.10 E-03$ \\
\hline TRITIUM & 1.98E-03 & & & 3.09E-04 & 2.29E-03 \\
\hline Pathway Totals & $3.16 \mathrm{E}-03$ & & 1.44E-05 & 3.09E-04 & $3.49 E-03$ \\
\hline \multicolumn{6}{|l|}{ Residential, Seep MB-10 } \\
\hline SR-90 & $2.49 E-04$ & & & & $2.49 \mathrm{E}-04$ \\
\hline TRITIUM & 5.20 E- 04 & & & 8.15E-05 & $6.02 E-04$ \\
\hline Pathway Totals & $7.70 \mathrm{E}-04$ & & & $8.15 E-05$ & 8.51E-04 \\
\hline Residential, Seep MB-11 & & & & & \\
\hline
\end{tabular}




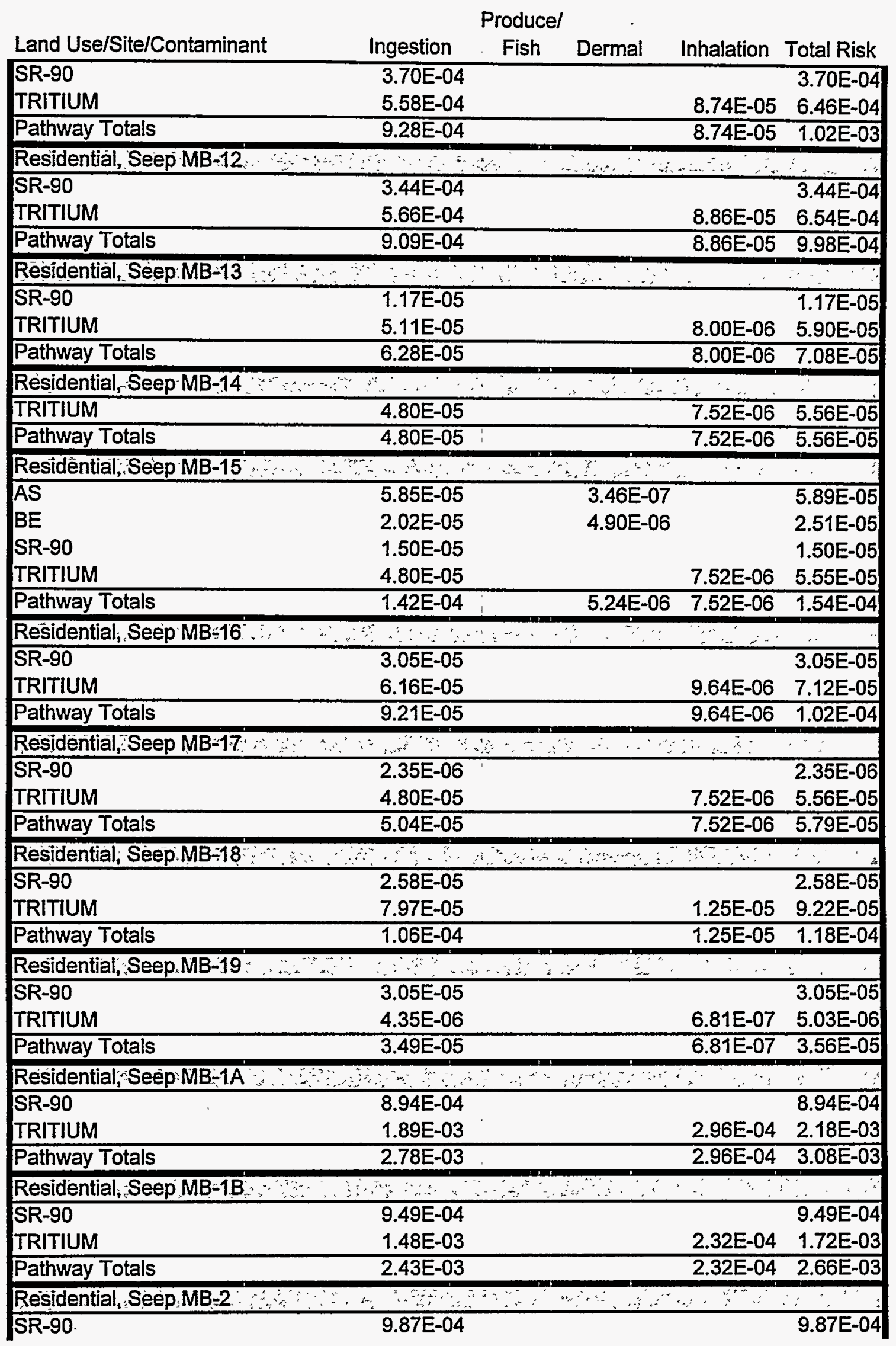




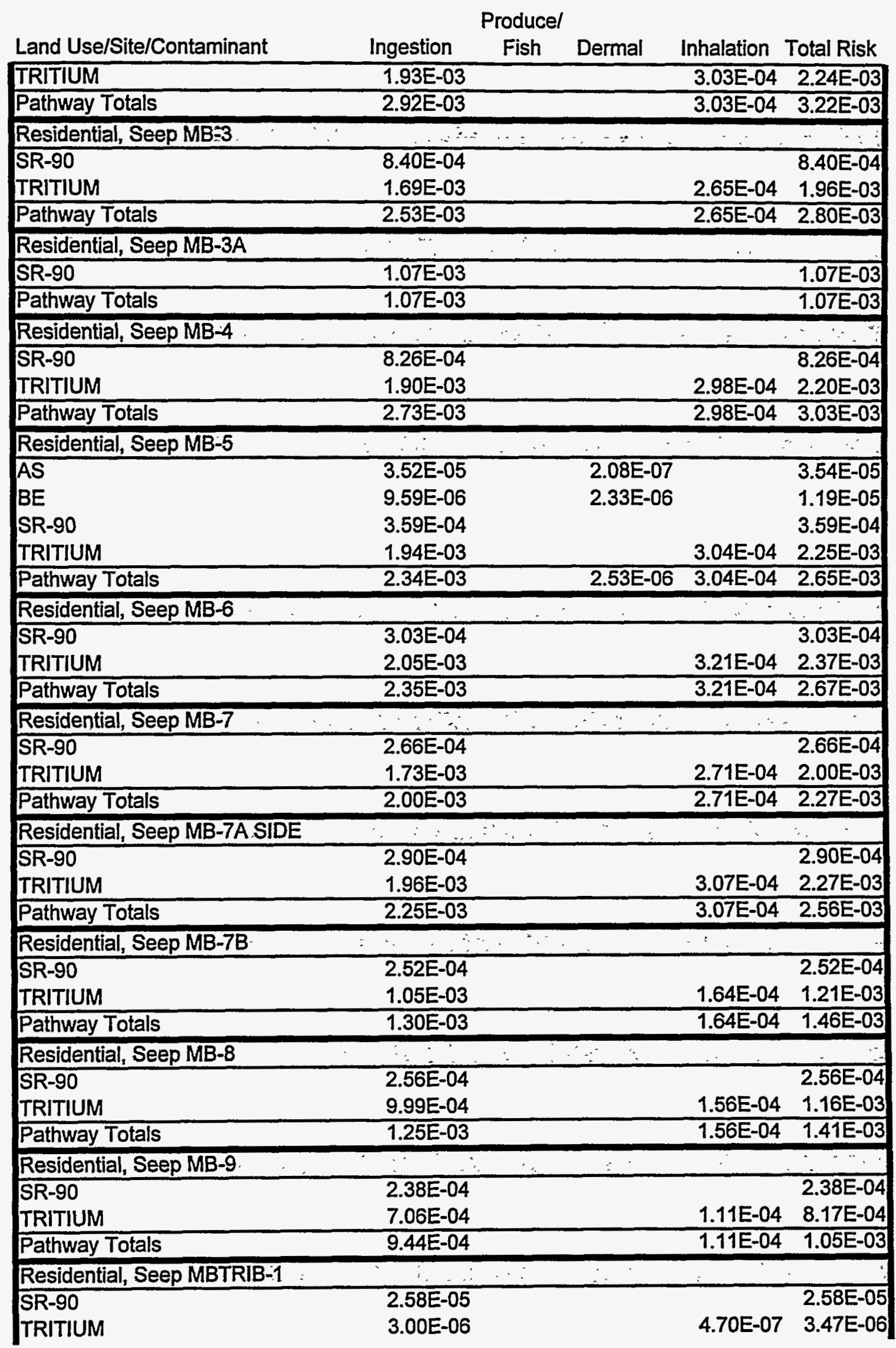




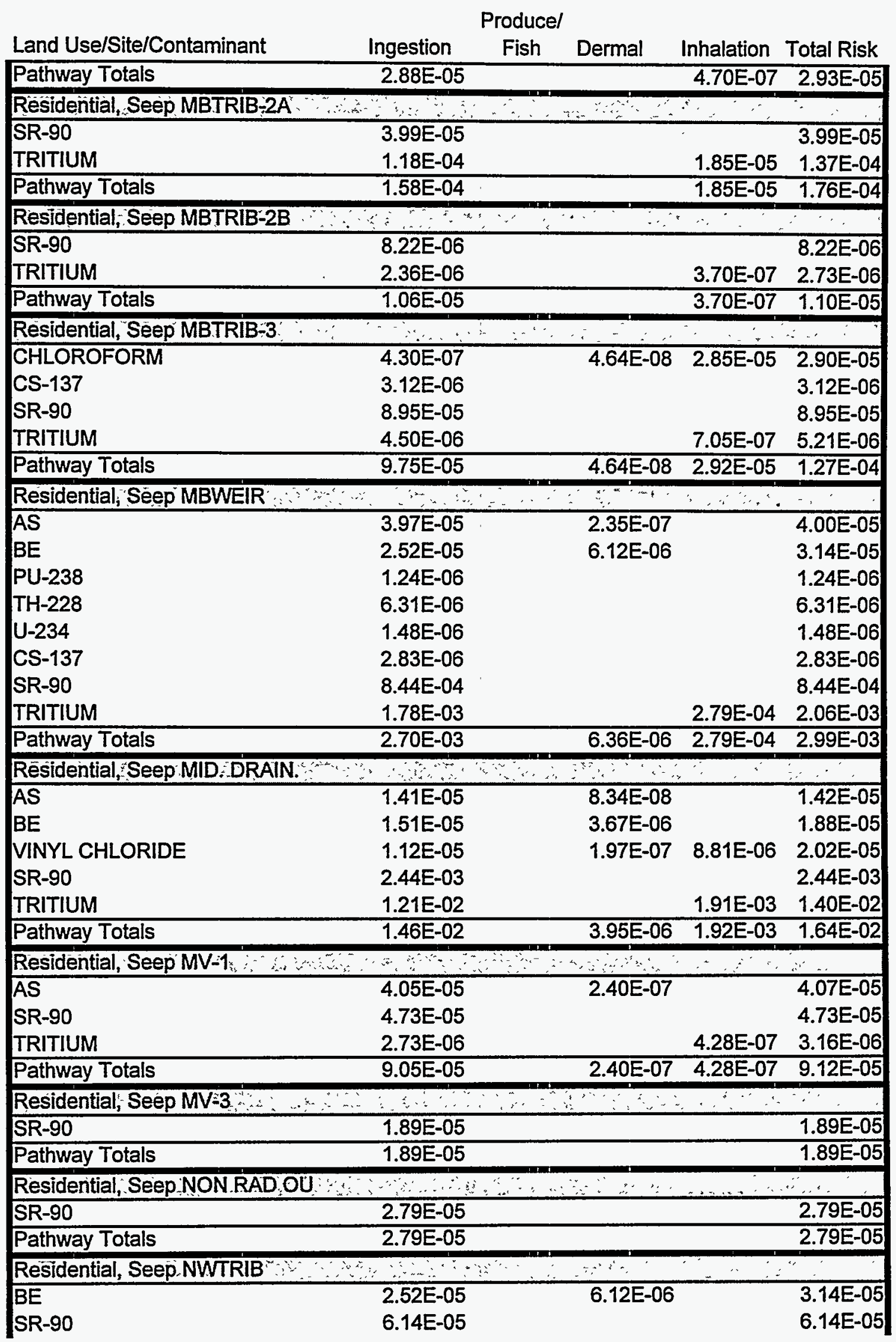




\begin{tabular}{|c|c|c|c|c|c|}
\hline \multirow{2}{*}{ Land Use/Site/Contaminant } & \multicolumn{3}{|c|}{ Producel } & \multirow{2}{*}{ Inhalation } & \multirow[b]{2}{*}{ Total Risk } \\
\hline & Ingestion & Fish & Dermal & & \\
\hline TRITIUM & 1.50E-06 & & & $2.35 \mathrm{E}-07$ & $\overline{1.74 \mathrm{E}-06}$ \\
\hline Pathway Totals & $8.82 \mathrm{E}-05$ & & $6.12 E-06$ & $2.35 \mathrm{E}-07$ & $9.45 \mathrm{E}-05$ \\
\hline \multicolumn{6}{|l|}{ Residential, Seep R-227 } \\
\hline $\mathrm{CO}-60$ & $2.03 E-05$ & & & & $2.03 \mathrm{E}-05$ \\
\hline SR-90 & 1.12E-04 & & & & $1.12 E-04$ \\
\hline TRITIUM & 3.99E-06 & & & $6.26 \mathrm{E}-07$ & 4.62E-06 \\
\hline Pathway Totals & 1.37E-04 & & & $6.26 \mathrm{E}-07$ & 1.37E-04 \\
\hline \multicolumn{6}{|l|}{ Residential, Seep R-311 } \\
\hline$\overline{\mathrm{BE}}$ & $1.41 \mathrm{E}-05$ & & $3.43 E-06$ & & $1.76 \mathrm{E}-05$ \\
\hline SR-90 & 3.17E-05 & & & & 3.17E-05 \\
\hline TRITIUM & 3.23E-06 & & & 5.06E-07 & $3.73 E-06$ \\
\hline Pathway Totals & 4.91E-05 & & $3.43 E-06$ & 5.06E-07 & $5.30 \mathrm{E}-05$ \\
\hline \multicolumn{6}{|l|}{ Residential, Seep RAC } \\
\hline SR-90 & 4.06E-05 & & & & $4.06 E-05$ \\
\hline TRITIUM & 2.94E-06 & & & 4.61E-07 & $3.40 E-06$ \\
\hline Pathway Totals & 4.36E-05 & & & 4.61E-07 & $4.40 \mathrm{E}-05$ \\
\hline \multicolumn{6}{|l|}{ Residential, Seep RS-1 } \\
\hline$\overline{A S}$ & $2.20 \mathrm{E}-04$ & & $1.30 \mathrm{E}-06$ & & 2.21E-04 \\
\hline$B E$ & 2.02E-05 & & 4.90E-06 & & 2.51E-05 \\
\hline AM-241 & 3.65E-06 & & & & 3.65E-06 \\
\hline U-234 & 3.24E-06 & & & & 3.24E-06 \\
\hline CO-60 & 6.07E-06 & & & & 6.07E-06 \\
\hline CS-137 & 9.86E-06 & & & & $9.86 E-06$ \\
\hline SR-90 & 2.05E-04 & & & & 2.05E-04 \\
\hline TRITIUM & 3.31E-05 & & & 5.19E-06 & 3.83E-05 \\
\hline Pathway Totals & 5.01E-04 & & $6.20 \mathrm{E}-06$ & 5.19E-06 & 5.12E-04 \\
\hline \multicolumn{6}{|l|}{ Residential, Seep'RS-3 } \\
\hline AS & 3.87E-04 & & 2.29E-06 & & 3.90E-04 \\
\hline BE & 2.02E-05 & & 4.90E-06 & & 2.51E-05 \\
\hline CO-60 & 4.53E-04 & & & & 4.53E-04 \\
\hline SR-90 & $1.08 E-03$ & & & & 1.08E-03 \\
\hline TRITIUM & 7.51E-05 & & & $1.18 E-05$ & 8.68E-05 \\
\hline Pathway Totals & $2.02 E-03$ & & $7.19 \mathrm{E}-06$ & $1.18 \mathrm{E}-05$ & $2.04 E-03$ \\
\hline \multicolumn{6}{|l|}{ Residential, Seep RS-3A } \\
\hline$\widehat{A S}$ & $3.52 E-04$ & & 2.08E-06 & & $3.54 \mathrm{E}-04$ \\
\hline BE & 4.46E-05 & & 1.08E-05 & & 5.55E-05 \\
\hline AM-241 & 1.44E-04 & & & & 1.44E-04 \\
\hline CM-243 & 2.68E-04 & & & & 2.68E-04 \\
\hline U-232 & $1.22 E-04$ & & & . & 1.22E-04 \\
\hline U-234 & 1.39E-03 & & & & 1.39E-03 \\
\hline U-235 & $6.14 E-06$ & & & & $6.14 \mathrm{E}-06$ \\
\hline U-238 & 8.36E-05 & & & & 8.36E-05 \\
\hline CO-60 & 3.82E-04 & & & & 3.82E-04 \\
\hline SR-90 & 1.27E-03 & & & & 1.27E-03 \\
\hline TRITIUM & 6.79E-05 & & & $1.06 E-05$ & 7.86E-05 \\
\hline Pathway Totals & 4.13E-03 & & $1.29 E-05$ & $1.06 \mathrm{E}-05$ & $4.15 \mathrm{E}-03$ \\
\hline
\end{tabular}




\begin{tabular}{|c|c|c|c|c|c|}
\hline \multirow[b]{2}{*}{ Land Use/Site/Contaminant } & \multicolumn{3}{|c|}{ Producel } & \multirow[b]{2}{*}{ Inhalation } & \multirow[b]{2}{*}{ Total Risk } \\
\hline & Ingestion & Fish & Dermal & & \\
\hline \multicolumn{6}{|l|}{ Residential, Seep RS-3B } \\
\hline PU-238 & 1.42E-06 & & & & 1.42E-06 \\
\hline U-232 & $9.60 E-06$ & & & & $9.60 \mathrm{E}-06$ \\
\hline U-234 & $1.25 \mathrm{E}-04$ & & & & $1.25 \mathrm{E}-04$ \\
\hline U-238 & 8.65E-06 & & & & 8.65E-06 \\
\hline co-60 & 5.23E-05 & & & & 5.23E-05 \\
\hline CS-137 & 5.49E-06 & & & & 5.49E-06 \\
\hline SR-90 & 5.44E-05 & & & & 5.44E-05 \\
\hline TRITIUM & $2.58 \mathrm{E}-05$ & & & 4.04E-06 & 2.98E-05 \\
\hline Pathway Totals & 2.83E-04 & & & 4.04E-06 & 2.87E-04 \\
\hline \multicolumn{6}{|l|}{ Residential, Seep SPD } \\
\hline AS & 3.87E-05 & & $2.29 \mathrm{E}-07$ & & $3.90 \mathrm{E}-05$ \\
\hline $\mathrm{BE}$ & 7.07E-06 & & 1.71E-06 & & 8.78E-06 \\
\hline SR-90 & 7.42E-02 & & & & 7.42E-02 \\
\hline TRITIUM & 1.69E-02 & & & 2.66E-03 & 1.95E-02 \\
\hline Pathway Totals & $8.98 \mathrm{E}-02$ & & 1.94E-06 & $2.66 \mathrm{E}-03$ & 9.22E-02 \\
\hline \multicolumn{6}{|l|}{ Residential Seep SW2-1 } \\
\hline $\mathrm{BE}$ & 2.02E-05 & & $4.90 \mathrm{E}-06$ & & 2.51E-05 \\
\hline CS-137 & 2.12E-06 & & & & 2.12E-06 \\
\hline SR-90 & $4.28 \mathrm{E}-04$ & & & & 4.28E-04 \\
\hline TRITIUM & 1.71E-05 & & & 2.68E-06 & $1.98 E-05$ \\
\hline Pathway Totals & $4.68 \mathrm{E}-04$ & & $4.90 \mathrm{E}-06$ & $2.68 \mathrm{E}-06$ & 4.75E-04 \\
\hline \multicolumn{6}{|l|}{ Residential, Seep SW2-2 } \\
\hline$\overline{B E}$ & 3.03E-05 & & 7.35E-06 & & 3.76E-05 \\
\hline CS-137 & 2.39E-06 & & & & 2.39E-06 \\
\hline SR-90 & 8.71E-04 & & & & 8.71E-04 \\
\hline TRITIUM & 7.51E-06 & & & 1.18E-06 & $8.68 \mathrm{E}-06$ \\
\hline Pathway Totals & 9.11E-04 & & $7.35 \mathrm{E}-06$ & 1.18E-06 & $9.20 E-04$ \\
\hline \multicolumn{6}{|c|}{ Residential, Seêp SW2-3, } \\
\hline $\mathrm{BE}$ & 2.52E-05 & & $6.12 E-06$ & & 3.14E-05 \\
\hline SR-90 & 2.34E-05 & & & & 2.34E-05 \\
\hline TRITIUM & $1.05 \mathrm{E}-05$ & & & $1.65 \mathrm{E}-06$ & $1.22 \mathrm{E}-05$ \\
\hline Pathway Totals & 5.91E-05 & & $6.12 \mathrm{E}-06$ & 1.65E-06 & $6.69 \mathrm{E}-05$ \\
\hline \multicolumn{6}{|l|}{ Residential, Seep:SW2-4: } \\
\hline$\overline{A S}$ & 5.28E-05 & & $3.13 \mathrm{E}-07$ & & $5.32 \mathrm{E}-05$ \\
\hline $\mathrm{CO}-60$ & 1.73E-06 & & & & 1.73E-06 \\
\hline CS-137 & 2.02E-05 & & & & 2.02E-05 \\
\hline SR-90 & 4.17E-04 & & & & 4.17E-04 \\
\hline TRITIUM & $1.86 \mathrm{E}-03$ & & & 2.91E-04 & 2.15E-03 \\
\hline Pathway Totals & 2.35E-03 & & $3.13 \mathrm{E}-07$ & 2.91E-04 & $2.64 \mathrm{E}-03$ \\
\hline \multicolumn{6}{|l|}{ Residential, Seep SW2-5, } \\
\hline$\overline{B E}$ & 8.58E-06 & & 2.08E-06 & & 1.07E-05 \\
\hline SR-90 & $1.50 E-01$ & & & & $1.50 \mathrm{E}-01$ \\
\hline TRITIUM & $1.64 E-02$ & & & 2.58E-03 & $1.89 \mathrm{E}-02$ \\
\hline Pathway Totals & $1.64 \mathrm{E}-01$ & & 2.08E-06 & $2.58 \mathrm{E}-03$ & $1.66 \mathrm{E}-01$ \\
\hline 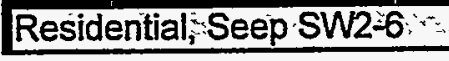 & $\cdots$ & & & & \\
\hline
\end{tabular}




\begin{tabular}{|c|c|c|c|c|c|}
\hline & & Produce & & & \\
\hline Land Use/Site/Contaminant & Ingestion & & Dermal & Inhalation & Total Risk \\
\hline$\overline{A S}$ & 1.76E-05 & & $1.04 \mathrm{E}-07$ & & 1.77E-05 \\
\hline $\mathrm{BE}$ & 8.58E-06 & & 2.08E-06 & & 1.07E-05 \\
\hline SR-90 & 4.51E-01 & & & & 4.51E-01 \\
\hline TRITIUM & 4.25E-03 & & & $6.65 \mathrm{E}-04$ & 4.91E-03 \\
\hline Pathway Totals & $4.53 \mathrm{E}-01$ & & 2.19E-06 & $6.65 \mathrm{E}-04$ & $4.54 \mathrm{E}-01$ \\
\hline \multicolumn{6}{|l|}{ Residential, Seep SW2-7 } \\
\hline AS & $2.47 E-05$ & & 1.46E-07 & & $2.48 \mathrm{E}-05$ \\
\hline$B E$ & $1.46 E-05$ & & $3.55 E-06$ & & 1.82E-05 \\
\hline SR-90 & 2.47E-01 & & & & 2.47E-01 \\
\hline TRITIUM & 4.07E-03 & & & 6.37E-04 & 4.71E-03 \\
\hline Pathway Totals & $2.50 \mathrm{E}-01$ & & $3.70 \mathrm{E}-06$ & $6.37 E-04$ & 2.50E-01 \\
\hline \multicolumn{6}{|l|}{ Residential, Seep SW4-1 } \\
\hline$\overline{A S}$ & 1.09E-04 & & $6.46 \mathrm{E}-07$ & & $1.10 \mathrm{E}-04$ \\
\hline BE & 4.04E-05 & & $9.79 E-06$ & & 5.02E-05 \\
\hline 1,1-DICHLOROETHENE & 3.52E-06 & & $7.60 \mathrm{E}-08$ & $3.52 E-05$ & $3.88 \mathrm{E}-05$ \\
\hline TRICHLOROETHENE & $1.16 \mathrm{E}-06$ & & 3.01E-07 & 3.17E-06 & 4.63E-06 \\
\hline VINYL CHLORIDE & $3.06 E-04$ & & 5.42E-06 & 2.42E-04 & 5.53E-04 \\
\hline TH-228 & 4.61E-06 & & & & 4.61E-06 \\
\hline$U-234$ & 4.52E-06 & & & & 4.52E-06 \\
\hline U-238 & 3.16E-06 & & & & $3.16 \mathrm{E}-06$ \\
\hline SR-90 & 6.67E-03 & & & & 6.67E-03 \\
\hline TRITIUM & 1.77E-03 & & & 2.77E-04 & 2.05E-03 \\
\hline Pathway Totals & 8.91E-03 & & $1.62 \mathrm{E}-05$ & $5.57 \mathrm{E}-04$ & $9.48 \mathrm{E}-03$ \\
\hline \multicolumn{6}{|l|}{ Residential, Seep SW4-2 } \\
\hline$\overline{B E}$ & $3.18 E-05$ & & 7.71E-06 & & 3.95E-05 \\
\hline 1,1-DICHLOROETHENE & 1.41E-05 & & $3.04 \mathrm{E}-07$ & 1.41E-04 & $1.55 E-04$ \\
\hline BENZENE & $1.02 E-06$ & & 5.36E-08 & 5.11E-06 & $6.18 \mathrm{E}-06$ \\
\hline TETRACHLOROETHENE & 1.83E-06 & & $1.64 \mathrm{E}-06$ & $3.52 E-07$ & $3.83 E-06$ \\
\hline TRICHLOROETHENE & 1.03E-06 & & 2.67E-07 & 2.82E-06 & 4.12E-06 \\
\hline VINYL CHLORIDE & 1.41E-03 & & 2.49E-05 & 1.11E-03 & 2.54E-03 \\
\hline TH-228 & 6.31E-06 & & & & 6.31E-06 \\
\hline U-234 & $3.90 \mathrm{E}-06$ & & & & 3.90E-06 \\
\hline CS-137 & 4.05E-04 & & & & 4.05E-04 \\
\hline SR-90 & $1.56 E-02$ & & & & $1.56 \mathrm{E}-02$ \\
\hline TRITIUM & -3.21E-05 & & & 5.02E-06 & 3.71E-05 \\
\hline Pathway Totals & $1.75 \mathrm{E}-02$ & & $3.49 \mathrm{E}-05$ & $1.26 \mathrm{E}-03$ & $1.88 \mathrm{E}-02$ \\
\hline \multicolumn{6}{|l|}{ Residential, Seep SW5-1 } \\
\hline AS & $6.16 \mathrm{E}-05$ & & 3.65E-07 & & $6.20 \mathrm{E}-05$ \\
\hline BE & 4.04E-05 & & $9.79 E-06$ & $\cdot$ & 5.02E-05 \\
\hline TRICHLOROETHENE & 2.58E-07 & & 6.68E-08 & 7.05E-07 & $1.03 E-06$ \\
\hline VINYL CHLORIDE & 4.46E-05 & & 7.90E-07 & $3.52 E-05$ & 8.06E-05 \\
\hline SR-90 & 1.35E-04 & & & & 1.35E-04 \\
\hline TC-99 & 1.83E-06 & & & & 1.83E-06 \\
\hline TRITIUM & $1.06 E-03$ & & & 1.67E-04 & 1.23E-03 \\
\hline$U-233 / 234$ & 3.92E-06 & & & & 3.92E-06 \\
\hline$U-238$ & 3.52E-06 & & & & 3.52E-06 \\
\hline
\end{tabular}




\begin{tabular}{|c|c|c|c|c|c|}
\hline Land Use/Site/Contaminant & Ingestion & $\begin{array}{l}\text { Produce/ } \\
\text { Fish }\end{array}$ & Dermal & Inhalation & Total Risk \\
\hline Pathway Totals & 1.36E-03 & & $1.10 \mathrm{E}-05$ & $2.03 E-04$ & 1.57E-03 \\
\hline Résidential, Seep:SW5-11 & $\therefore$ & & $\therefore \because$ & $\therefore$ & $\therefore x$ \\
\hline$\overline{\mathrm{BE}}$ & $2.02 E-05$ & & $4.90 \mathrm{E}-06$ & & $2.51 E-05$ \\
\hline C-14 & 1.10E-05 & & & & $1.10 \mathrm{E}-05$ \\
\hline $\mathrm{CA}-45$ & 6.36E-04 & & & & $6.36 \mathrm{E}-04$ \\
\hline SR-90 & 7.50E-01 & & & & 7.50E-01 \\
\hline TC-99 & 4.65E-05 & & & & 4.65E-05 \\
\hline TH-228 & $1.41 \mathrm{E}-06$ & & & & 1.41E-06 \\
\hline TRITIUM & 1.36E-01 & & & 2.26E-02 & $1.56 \mathrm{E}-01$ \\
\hline$U-233 / 234$ & 3.54E-04 & & & & 3.54E-04 \\
\hline U-238 & 2.12E-06 & & & & 2.12E-06 \\
\hline Pathway Totals & $7.84 \mathrm{E}-01$ & & 4.90E-06 & $2.26 \mathrm{E}-02$ & $7.89 \mathrm{E}-01$ \\
\hline \multicolumn{6}{|l|}{ Residential; Seep SW5-2 } \\
\hline $\mathrm{BE}$ & $3.53 E-05$ & & 8.57E-06 & & $4.39 E-05$ \\
\hline CHLOROFORM & 1.43E-07 & & 1.55E-08 & 9.51E-06 & 9.67E-06 \\
\hline TRICHLOROETHENE & 9.82E-06 & & 2.54E-06 & 2.68E-05 & 3.91E-05 \\
\hline C-14 & 2.12E-06 & & & & 2.12E-06 \\
\hline Co-60 & 1.26E-05 & & & & $1.26 \mathrm{E}-05$ \\
\hline CS-137 & 1.75E-05 & & & & 1.75E-05 \\
\hline RA-228 & $1.42 E-04$ & & & & 1.42E-04 \\
\hline SR-90 & $3.01 \mathrm{E}-04$ & & & & 3.01E-04 \\
\hline TRITIUM & $4.80 \mathrm{E}-05$ & & & 7.52E-06 & 5.56E-05 \\
\hline Pathway Totals & $5.68 \mathrm{E}-04$ & & 1.11E-05 & $4.38 \mathrm{E}-05$ & $6.23 E-04$ \\
\hline \multicolumn{6}{|l|}{ Residential, Seep SW5-3 } \\
\hline $\mathrm{BE}$ & $2.02 E-05$ & & $4.90 E-06$ & & 2.51E-05 \\
\hline CHLOROFORM & 1.43E-07 & & 1.55E-08 & 9.51E-06 & 9.67E-06 \\
\hline TRICHLOROETHENE & 2.20E-06 & & 5.68E-07 & 5.99E-06 & 8.75E-06 \\
\hline C-14 & $1.36 \mathrm{E}-05$ & & & & 1.36E-05 \\
\hline$C A-45$ & 5.09E-06 & & & & 5.09E-06 \\
\hline CS-137 & $1.46 \mathrm{E}-06$ & & & & 1.46E-06 \\
\hline$K-40$ & 3.94E-05 & & & & 3.94E-05 \\
\hline SR-90 & 2.34E-03 & & & & 2.34E-03 \\
\hline TC-99 & $6.23 E-06$ & & & & $6.23 E-06$ \\
\hline TRITIUM & $1.46 \mathrm{E}-02$ & & & 2.30E-03 & 1.69E-02 \\
\hline Pathway Totals & 1.70E-02 & & $5.48 \mathrm{E}-06$ & $2.32 E-03$ & 1.93E-02 \\
\hline \multicolumn{6}{|c|}{ Residential, Seep SW5-4 } \\
\hline AS & 5.28E-05 & & 3.13E-07 & & $5.32 E-05$ \\
\hline BE & 2.02E-05 & & 4.90E-06 & & 2.51E-05 \\
\hline AM-241 & 1.43E-05 & & & & 1.43E-05 \\
\hline CM-243 & 7.99E-05 & & & & 7.99E-05 \\
\hline PU-238 & 2.79E-06 & & & & 2.79E-06 \\
\hline TH-228 & 3.30E-06 & & & & 3.30E-06 \\
\hline C-14 & $6.27 E-06$ & & & & 6.27E-06 \\
\hline $\mathrm{CA}-45$ & 3.73E-04 & & & & 3.73E-04 \\
\hline SR-90 & 4.18E-01 & & & & 4.18E-01 \\
\hline TC-99 & 6.23E-05 & & & & 6.23E-05 \\
\hline TRITIUM & 9.19E-03 & & & $1.44 E-03$ & 1.06E-02 \\
\hline
\end{tabular}




\begin{tabular}{|c|c|c|c|c|c|}
\hline & & roduce & & & \\
\hline Land Use/Site/Contaminant & Ingestion & Fish & Dermal & Inhalation & Total Risk \\
\hline Pathway Totals & $4.23 \mathrm{E}-01$ & & 5.21E-06 & $1.44 \mathrm{E}-03$ & 4.24E-01 \\
\hline Residential, Seep SW5-5 & & & & - & \\
\hline $\mathrm{BE}$ & $2.42 E-05$ & & 5.88E-06 & & 3.01E-05 \\
\hline TRICHLOROETHENE & 3.87E-07 & & $1.00 E-07$ & $1.06 \mathrm{E}-06$ & $1.54 \mathrm{E}-06$ \\
\hline VINYL CHLORIDE & 3.57E-04 & & 6.32E-06 & 2.82E-04 & $6.45 E-04$ \\
\hline C-14 & 9.08E-06 & & & & $9.08 \mathrm{E}-06$ \\
\hline SR-90 & $1.50 \mathrm{E}-03$ & & & & $1.50 \mathrm{E}-03$ \\
\hline TC-99 & $1.16 \mathrm{E}-06$ & & & & 1.16E-06 \\
\hline TH-228 & 1.16E-06 & & & & 1.16E-06 \\
\hline TRITIUM & 1.69E-02 & & & 2.66E-03 & 1.95E-02 \\
\hline $\mathrm{U}-233 / 234$ & $1.86 \mathrm{E}-06$ & & & & $1.86 E-06$ \\
\hline Pathway Totals & $1.87 \mathrm{E}-02$ & & $1.23 E-05$ & $2.94 \mathrm{E}-03$ & $2.16 E-02$ \\
\hline Residential, Seep SW5-6 & & & & & \\
\hline$\overline{\mathrm{BE}}$ & 1.51E-05 & & 3.67E-06 & & $1.88 \mathrm{E}-05$ \\
\hline 1,2-DICHLOROPROPANE & 7.98E-07 & & 2.62E-08 & & 8.25E-07 \\
\hline TRICHLOROETHENE & $6.46 \mathrm{E}-07$ & & 1.67E-07 & $1.76 \mathrm{E}-06$ & 2.57E-06 \\
\hline VINYL CHLORIDE & $1.78 \mathrm{E}-04$ & & 3.16E-06 & 1.41E-04 & 3.23E-04 \\
\hline AM-241 & 2.22E-04 & & & & 2.22E-04 \\
\hline C-14 & 1.21E-05 & & & & 1.21E-05 \\
\hline RA-226 & 1.74E-06 & & & & $1.74 E-06$ \\
\hline SR-90 & 4.87E-02 & & & & 4.87E-02 \\
\hline TRITIUM & $1.59 \mathrm{E}-02$ & & & 2.52E-03 & 1.84E-02 \\
\hline Pathway Totals & $6.43 E-02$ & & $7.03 E-06$ & 2.66E-03 & 6.68E-02 \\
\hline Residential, Seep SW5-7. & & & & $\ldots$ & \\
\hline AS & $5.28 \mathrm{E}-05$ & & $3.13 E-07$ & & 5.32E-05 \\
\hline $\mathrm{BE}$ & 1.51E-05 & & 3.67E-06 & & 1.88E-05 \\
\hline CS-137 & 2.55E-05 & & & & 2.55E-05 \\
\hline SR-90 & 5.47E-03 & & & & 5.47E-03 \\
\hline TRITIUM & $1.73 \mathrm{E}-01$ & & & 2.94E-02 & $1.98 E-01$ \\
\hline Pathway Totals & $1.78 \mathrm{E}-01$ & & 3.99E-06 & $2.94 \mathrm{E}-02$ & 2.02E-01 \\
\hline Residential; Seep SW5-8 & & & & & \\
\hline ALPHA-BHC & $2.96 \mathrm{E}-05$ & & 1.39E-06 & & 3.10E-05 \\
\hline BETA-BHC & 1.44E-06 & & 8.50E-08 & & 1.52E-06 \\
\hline DICHLOROBENZENE,1,4- & 1.97E-06 & & 3.30E-07 & & 2.30E-06 \\
\hline C-14 & 3.24E-06 & & & & $3.24 \mathrm{E}-06$ \\
\hline $\mathrm{CA}-45$ & 1.95E-06 & & & & $1.95 \mathrm{E}-06$ \\
\hline CS-137 & 5.04E-06 & & & & $5.04 E-06$ \\
\hline RA-228 & 7.81E-05 & & & & 7.81E-05 \\
\hline SR-90 & $3.45 E-04$ & & & & $3.45 E-04$ \\
\hline TRITIUM & $5.22 \mathrm{E}-02$ & & & $8.40 E-03$ & 6.02E-02 \\
\hline Pathway Totals & 5.27E-02 & & 1.81E-06 & $8.40 \mathrm{E}-0 \overline{3}$ & $6.06 \mathrm{E}-02$ \\
\hline Residential,.Seep SW5-9 & $\therefore$ & & & & \\
\hline AS & $5.28 E-05$ & & 3.13E-07 & & $5.32 \mathrm{E}-05$ \\
\hline$B E$ & 2.02E-05 & & 4.90E-06 & & 2.51E-05 \\
\hline DICHLOROBENZENE,1,4- & 1.97E-06 & & 3.30E-07 & & $2.30 \mathrm{E}-06$ \\
\hline TRICHLOROETHENE & 7.75E-07 & & $2.00 \mathrm{E}-07$ & 2.11E-06 & 3.09E-06 \\
\hline
\end{tabular}




\begin{tabular}{|c|c|c|c|c|c|}
\hline & & Produce/ & & & \\
\hline Land Use/Site/Contaminant & Ingestion & Fish & Dermal & Inhalation & Total Risk \\
\hline VINYL CHLORIDE & $4.46 E-05$ & & $7.90 \mathrm{E}-07$ & 3.52E-05 & $8.06 \mathrm{E}-05$ \\
\hline C-14 & 6.06E-06 & & & & $6.06 \mathrm{E}-06$ \\
\hline CS-137 & $1.20 \mathrm{E}-05$ & & & & $1.20 \mathrm{E}-05$ \\
\hline SR-90 & 8.23E-04 & & & & 8.23E-04 \\
\hline TRITIUM & 5.94E-02 & & & $9.59 \mathrm{E}-03$ & $6.84 E-02$ \\
\hline Pathway Totals & $6.03 E-02$ & & $6.53 \mathrm{E}-06$ & $9.63 \mathrm{E}-03$ & 6.93E-02 \\
\hline Residential, Seep SW6-1. & $\therefore \therefore$ & & & & \\
\hline $\mathrm{BE}$ & $1.01 E-05$ & & $2.45 E-06$ & & $1.25 \mathrm{E}-05$ \\
\hline $\mathrm{CO}-60$ & $1.09 E-05$ & & & & 1.09E-05 \\
\hline CS-137 & 9.09E-06 & & & & $9.09 E-06$ \\
\hline SR-90 & 1.17E-05 & & & & 1.17E-05 \\
\hline TRITIUM & 3.32E-04 & & & 5.20E-05 & 3.84E-04 \\
\hline Pathway Totals & 3.74E-04 & & $2.45 \mathrm{E}-06$ & $5.20 \mathrm{E}-05$ & $4.28 \mathrm{E}-04$ \\
\hline Residential, Seep SW6-2 : & $\therefore$ & & & $\div$ & - \\
\hline AS & 3.52E-05 & & $2.08 \mathrm{E}-07$ & & $3.54 \mathrm{E}-05$ \\
\hline TRITIUM & $2.45 \mathrm{E}-03$ & & & 3.84E-04 & 2.84E-03 \\
\hline Pathway Totals & $2.49 E-03$ & & 2.08E-07 & 3.84E-04 & 2.87E-03 \\
\hline Residential,Seep SW7-1. & 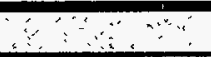 & & & & \\
\hline$\overline{\mathrm{BE}}$ & $2.02 E-05$ & & 4.90E-06 & & 2.51E-05 \\
\hline SR-90 & 8.17E-05 & & & & 8.17E-05 \\
\hline TRITIUM & 4.07E-05 & & & $6.37 \mathrm{E}-06$ & 4.71E-05 \\
\hline Pathway Totals & $1.43 E-04$ & & $4.90 \mathrm{E}-06$ & 6.37E-06 & $1.54 \mathrm{E}-04$ \\
\hline Residential, Seep.SW7-2 & $=$ & $\therefore$ & & & \\
\hline $\mathrm{BE}$ & $2.02 \mathrm{E}-05$ & & 4.90E-06 & & 2.51E-05 \\
\hline CO-60 & $6.20 \mathrm{E}-04$ & & & & $6.20 E-04$ \\
\hline CS-137 & 1.17E-05 & & & & 1.17E-05 \\
\hline SR-90 & $3.40 \mathrm{E}-05$ & & & & 3.40E-05 \\
\hline TRITIUM & 1.27E-05 & & & $1.99 E-06$ & 1.47E-05 \\
\hline Pathway Totals & $6.98 \mathrm{E}-04$ & & 4.90E-06 & 1.99E-06 & $7.05 E-04$ \\
\hline Residential, Seep SW7-3 & $\therefore \cdots \%$ & & $\therefore \quad \cdots$ & $\therefore$ & \\
\hline AS & $6.23 \mathrm{E}-05$ & & $3.69 \mathrm{E}-07$ & & 6.27E-05 \\
\hline$B E$ & 2.52E-05 & & $6.12 E-06$ & & $3.14 \mathrm{E}-05$ \\
\hline AM-241 & 6.47E-06 & & & & 6.47E-06 \\
\hline $\mathrm{CM}-243$ & $1.49 E-05$ & & & & 1.49E-05 \\
\hline TH-228 & 5.34E-06 & & & & 5.34E-06 \\
\hline$U-232$ & 3.84E-04 & & & & 3.84E-04 \\
\hline$U-234$ & 3.86E-03 & & & & 3.86E-03 \\
\hline$U-235$ & 1.48E-05 & & & & 1.48E-05 \\
\hline U-238 & $1.32 E-04$ & & & & 1.32E-04 \\
\hline $\mathrm{co}-60$ & $1.37 \mathrm{E}-03$ & & & & 1.37E-03 \\
\hline SR-90 & 8.00E-05 & & & & 8.00E-05 \\
\hline TRITIUM & 4.30E-05 & & & $6.73 E-06$ & 4.97E-05 \\
\hline Pathway Totals & $6.00 \mathrm{E}-03$ & & 6.49E-06 & $6.73 E-06$ & $6.02 \mathrm{E}-03$ \\
\hline Residential; Seep SW7-4 & $\because \div$ & & & $\because$ & \\
\hline $\mathrm{BE}$ & $2.52 \mathrm{E}-05$ & & $6.12 E-06$ & & 3.14E-05 \\
\hline cọ-60 & $6.55 \mathrm{E}-05$ & & & & $6.55 E-05$ \\
\hline
\end{tabular}




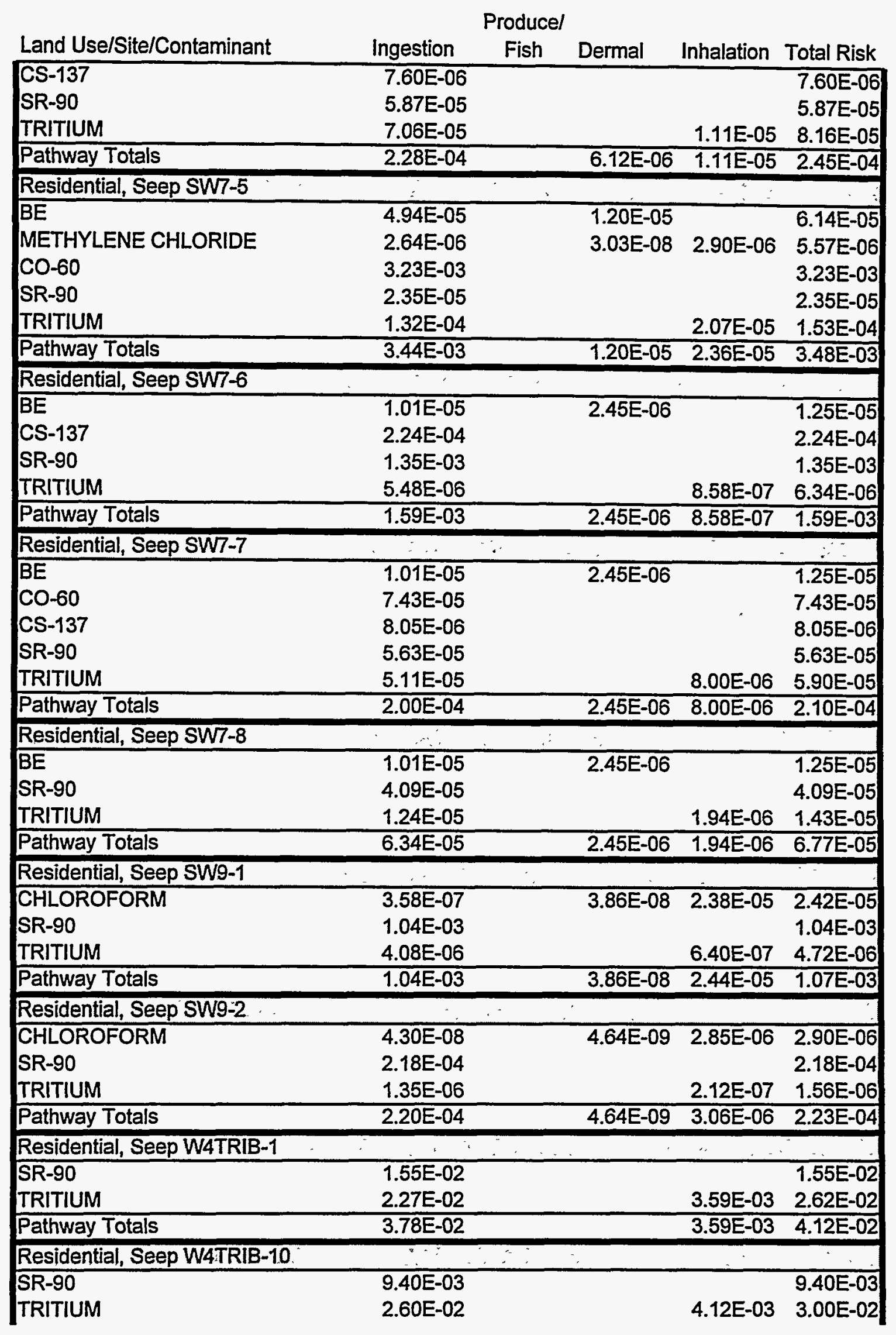


Producel

\begin{tabular}{|c|c|c|c|c|c|}
\hline Land Use/Site/Contaminant & Ingestion & Fish & Dermal & Inhalation & Total Risk \\
\hline Pathway Totals & $3.51 \mathrm{E}-02$ & & & $4.12 E-03$ & $3.90 \mathrm{E}-02$ \\
\hline \multicolumn{6}{|l|}{ Reșidential, Seep W4TRIB=11 } \\
\hline AS & $9.69 \mathrm{E}-06$ & & $5.73 E-08$ & & $9.74 E-06$ \\
\hline BE & 1.01E-05 & & 2.45E-06 & & 1.25E-05 \\
\hline VINYL CHLORIDE & 4.46E-06 & & 7.90E-08 & 3.52E-06 & 8.06E-06 \\
\hline CS -137 & $7.25 \mathrm{E}-05$ & & & & 7.25E-05 \\
\hline SR-90 & $1.45 E-02$ & & & & $1.45 E-02$ \\
\hline TRITIUM & 2.90E-02 & & & 4.61E-03 & 3.34E-02 \\
\hline Pathway Totals & $4.32 \mathrm{E}-02$ & & $2.59 \mathrm{E}-06$ & 4.61E-03 & $4.76 \mathrm{E}-02$ \\
\hline \multicolumn{6}{|l|}{ Residential, Seep W4TRIB 12} \\
\hline$\overline{\text { SR-90 }}$ & $7.11 \mathrm{E}-03$ & & & & $7.11 \mathrm{E}-03$ \\
\hline TRITIUM & 2.75E-04 & & & 4.31E-05 & $3.18 \mathrm{E}-04$ \\
\hline Pathway Totals & $7.39 \mathrm{E}-03$ & & & $4.31 \mathrm{E}-05$ & $7.43 \mathrm{E}-03$ \\
\hline \multicolumn{6}{|l|}{ Residential; Seep W4TRIB-2 } \\
\hline SR-90 & 1.61E-02 & & & & 1.61E-02 \\
\hline TRITIUM & 2.36E-02 & & & 3.75E-03 & 2.73E-02 \\
\hline Pathway Totals & 3.93E-02 & & & 3.75E-03 & 4.29E-02 \\
\hline \multicolumn{6}{|l|}{ Residential; Seep W4TRIB-3 } \\
\hline SR-90 & 1.04E-02 & & & & 1.04E-02 \\
\hline TRITIUM & 2.58E-02 & & & 4.10E-03 & 2.98E-02 \\
\hline Pathway Totals & 3.59E-02 & & & 4.10E-03 & 3.99E-02 \\
\hline \multicolumn{6}{|l|}{ Residential; Seep W4TRIB-4 } \\
\hline CS-137 & $1.62 E-05$ & & & & 1.62E-05 \\
\hline SR-90 & 9.67E-03 & & & & 9.67E-03 \\
\hline TRITIUM & $2.68 \mathrm{E}-02$ & & & 4.26E-03 & $3.10 \mathrm{E}-02$ \\
\hline Pathway Totals & $3.62 E-02$ & & & 4.26E-03 & 4.03E-02 \\
\hline \multicolumn{6}{|c|}{ Residential, Seep W4TRIB-5 } \\
\hline SR-90 & $1.13 E-02$ & & & & 1.13E-02 \\
\hline TRITIUM & 1.66E-02 & & & 2.62E-03 & $1.92 E-02$ \\
\hline Pathway Totals & 2.77E-02 & & & $2.62 E-03$ & 3.03E-02 \\
\hline \multicolumn{6}{|l|}{ Residential; Seep W4TRIB-6: } \\
\hline SR-90 & 8.83E-03 & & & & 8.83E-03 \\
\hline TRITIUM & $3.16 \mathrm{E}-02$ & & & $5.02 E-03$ & 3.64E-02 \\
\hline Pathway Totals & $4.01 \mathrm{E}-02$ & & & $5.02 \mathrm{E}-03$ & 4.49E-02 \\
\hline \multicolumn{6}{|l|}{ Residential, Seep W4TRIB:7 } \\
\hline SR-90 & $2.13 E-02$ & & & & $2.13 \mathrm{E}-02$ \\
\hline TRITIUM & 4.44E-02 & & & 7.11E-03 & $5.12 \mathrm{E}-02$ \\
\hline Pathway Totals & 6.47E-02 & & & $7.11 \mathrm{E}-03$ & $7.13 \mathrm{E}-02$ \\
\hline \multicolumn{6}{|c|}{ Residential, Seep W4TRIB-8 } \\
\hline SR-90 & $8.62 E-03$ & & & & 8.62E-03 \\
\hline TRITIUM & 3.17E-02 & & & 5.04E-03 & 3.65E-02 \\
\hline Pathway Totals & $4.00 \mathrm{E}-02$ & & & $5.04 E-03$ & $4.48 \mathrm{E}-02$ \\
\hline \multicolumn{6}{|l|}{ Residential $;$ Seep W4TRIB-9: } \\
\hline SR-90 & $8.60 E-03$ & & & & $8.60 \mathrm{E}-03$ \\
\hline TRITIUM & 3.32E-02 & & & 5.28E-03 & 3.83E-02 \\
\hline Pathway Totals & 4.14E-02 & & & $5.28 \mathrm{E}-03$ & 4.65E-02 \\
\hline
\end{tabular}




\begin{tabular}{|c|c|c|c|c|c|}
\hline Land Use/Site/Contaminant & Ingestion & $\begin{array}{c}\text { Producel } \\
\text { Fish } \\
\end{array}$ & Dermal & Inhalation & Total Risk \\
\hline Residential, Seep W6MS3 & $\approx$ & & & & \\
\hline SR-90 & $3.29 \mathrm{E}-04$ & & & & $3.29 \mathrm{E}-04$ \\
\hline TRITIUM & 3.47E-03 & & & 5.44E-04 & 4.02E-03 \\
\hline Pathway Totals & $3.80 \mathrm{E}-03$ & & & 5.44E-04 & $4.35 \mathrm{E}-03$ \\
\hline \multicolumn{6}{|l|}{ Residential, Seep WAG4 MS1 } \\
\hline$\overline{B E}$ & $3.92 \mathrm{E}-05$ & & $9.51 E-06$ & & 4.87E-05 \\
\hline VINYL CHLORIDE & 4.46E-06 & & 7.90E-08 & $3.52 E-06$ & 8.06E-06 \\
\hline TH-228 & $1.70 \mathrm{E}-05$ & & & & $1.70 \mathrm{E}-05$ \\
\hline$U-234$ & 2.71E-05 & & & & 2.71E-05 \\
\hline U-238 & $1.69 \mathrm{E}-05$ & & & & 1.69E-05 \\
\hline SR-90 & $1.25 E-02$ & & & & $1.25 E-02$ \\
\hline TRITIUM & 1.83E-02 & & & 2.89E-03 & 2.11E-02 \\
\hline Pathway Totals & 3.06E-02 & & $9.59 E-06$ & 2.89E-03 & $3.34 \mathrm{E}-02$ \\
\hline \multicolumn{6}{|l|}{ Residential, Seep WAG4 T2A } \\
\hline $\mathrm{BE}$ & $2.52 \mathrm{E}-05$ & & $6.12 E-06$ & & $3.14 \mathrm{E}-05$ \\
\hline TRICHLOROETHENE & $2.58 E-07$ & & $6.68 \mathrm{E}-08$ & 7.05E-07 & 1.03E-06 \\
\hline VINYL CHLORIDE & 2.23E-05 & & $3.95 \mathrm{E}-07$ & 1.76E-05 & 4.03E-05 \\
\hline CS-137 & 1.71E-04 & & & & 1.71E-04 \\
\hline SR-90 & $9.45 E-03$ & & & & $9.45 \mathrm{E}-03$ \\
\hline TRITIUM & 1.41E-02 & & & $2.22 E-03$ & 1.63E-02 \\
\hline Pathway Totals & $2.36 \mathrm{E}-02$ & & $6.58 \mathrm{E}-06$ & $2.24 \mathrm{E}-03$ & $2.58 \mathrm{E}-02$ \\
\hline \multicolumn{6}{|l|}{ Residential, Seep WAG6 MS1 } \\
\hline$\overline{B E}$ & 3.03E-05 & & $7.35 E-06$ & & $3.76 \mathrm{E}-05$ \\
\hline SR-90 & $7.75 E-05$ & & & & 7.75E-05 \\
\hline TRITIUM & 5.75E-04 & & & $9.01 E-05$ & 6.65E-04 \\
\hline Pathway Totals & $6.83 \mathrm{E}-04$ & & $7.35 \mathrm{E}-06$ & 9.01E-05 & $7.80 E-04$ \\
\hline \multicolumn{6}{|l|}{ Residential, Seep WAG6.MS1-1 } \\
\hline$\overline{A S}$ & 7.05E-05 & & 4.17E-07 & & $7.09 \mathrm{E}-05$ \\
\hline SR-90 & 2.58E-05 & & & & 2.58E-05 \\
\hline TRITIUM & 7.28E-04 & & & 1.14E-04 & 8.42E-04 \\
\hline Pathway Totals & $8.25 E-04$ & & 4.17E-07 & $1.14 E-04$ & $9.39 \mathrm{E}-04$ \\
\hline \multicolumn{6}{|l|}{ Residential, Seep WAG6 MS2 } \\
\hline$B E$ & $2.52 E-05$ & & $6.12 E-06$ & & $3.14 \mathrm{E}-05$ \\
\hline 1,1,2-TRICHLOROETHANE & 6.69E-07 & & $1.68 E-08$ & 3.35E-06 & 4.03E-06 \\
\hline 1,2-DICHLOROETHANE & 1.07E-06 & & 1.37E-08 & 5.34E-06 & $6.42 E-06$ \\
\hline 1,2-DICHLOROPROPANE & 7.98E-07 & & $2.62 E-08$ & & 8.25E-07 \\
\hline BENZENE & 3.41E-07 & & 1.79E-08 & 1.70E-06 & 2.06E-06 \\
\hline CARBON TETRACHLORIDE & 1.53E-06 & & $1.25 E-07$ & 3.11E-06 & 4.76E-06 \\
\hline CHLOROFORM & 7.16E-08 & & 7.73E-09 & 4.76E-06 & 4.83E-06 \\
\hline DIBROMOCHLOROMETHANE & 9.86E-07 & & $1.55 E-08$ & & $1.00 \mathrm{E}-06$ \\
\hline TRICHLOROETHENE & 3.87E-07 & & $1.00 E-07$ & $1.06 \mathrm{E}-06$ & $1.54 \mathrm{E}-06$ \\
\hline SR-90 & 8.40E-05 & & & & 8.40E-05 \\
\hline TRITIUM & 4.22E-03 & & & 6.61E-04 & 4.89E-03 \\
\hline Pathway Totals & 4.34E-03 & & $6.45 \mathrm{E}-06$ & $6.81 E-04$ & $5.03 E-03$ \\
\hline \multicolumn{6}{|l|}{ Residential, Seep WAG6 MS3A } \\
\hline AS & $5.28 E-05$ & & -07 & & $5.32 E-05$ \\
\hline
\end{tabular}




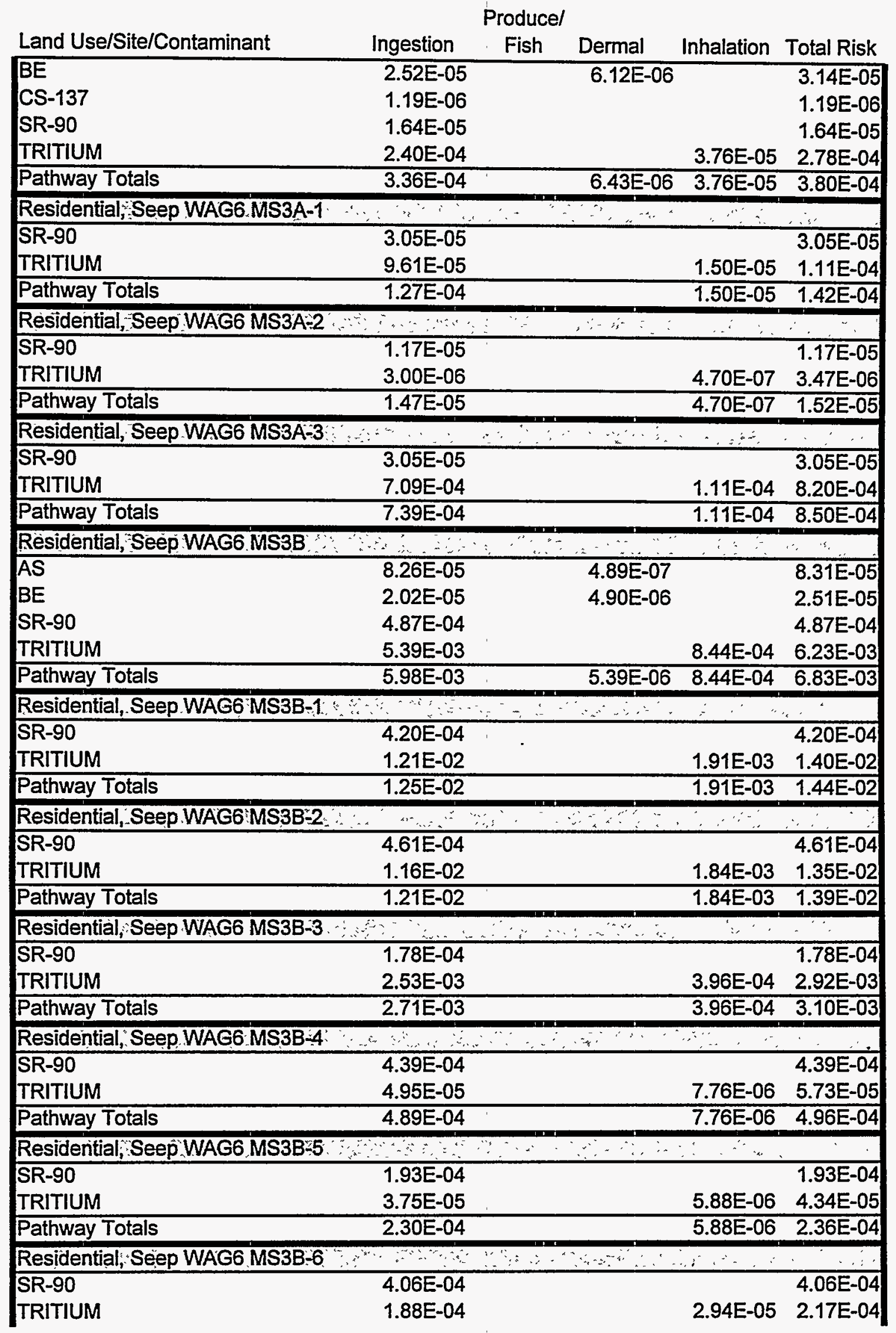




\begin{tabular}{|c|c|c|c|c|}
\hline Land Use/Site/Contaminant & Ingestion & $\begin{array}{l}\text { Producel } \\
\text { Fish Dermal }\end{array}$ & Inhalation & Total Risk \\
\hline Pathway Totals & $5.94 E-04$ & & $2.94 \mathrm{E}-05$ & $6.23 \mathrm{E}-04$ \\
\hline \multicolumn{5}{|l|}{ Residential, Seep WC-1 } \\
\hline CS-137 & $3.23 \mathrm{E}-05$ & & & 3.23E-05 \\
\hline SR-90 & 4.28E-04 & & & 4.28E-04 \\
\hline TRITIUM & 2.85E-04 & & 4.47E-05 & 3.30E-04 \\
\hline Pathway Totals & $7.46 \mathrm{E}-04$ & & 4.47E-05 & 7.90E-04 \\
\hline \multicolumn{5}{|l|}{ Residential, Seep WC-10 } \\
\hline SR-90 & 1.45E-04 & & & $1.45 E-04$ \\
\hline TRITIUM & $6.39 \mathrm{E}-05$ & & 1.00E-05 & $7.39 \mathrm{E}-05$ \\
\hline Pathway Totals & $2.09 \mathrm{E}-04$ & & $1.00 \mathrm{E}-05$ & $2.19 \mathrm{E}-04$ \\
\hline \multicolumn{5}{|l|}{ Residential, Seep WC-11 } \\
\hline SR-90 & $1.75 \mathrm{E}-04$ & & & $1.75 \mathrm{E}-04$ \\
\hline TRITIUM & $6.68 \mathrm{E}-05$ & & $1.05 \mathrm{E}-05$ & 7.72E-05 \\
\hline Pathway Totals & $2.42 E-04$ & & 1.05E-05 & $2.52 \mathrm{E}-04$ \\
\hline \multicolumn{5}{|l|}{ Residential, Seep WC-12 } \\
\hline SR-90 & $2.07 E-04$ & & & 2.07E-04 \\
\hline TRITIUM & $6.99 E-05$ & & $1.09 E-05$ & 8.08E-05 \\
\hline Pathway Totals & $2.76 \mathrm{E}-04$ & & 1.09E-05 & 2.87E-04 \\
\hline \multicolumn{5}{|l|}{ Residential, Seep WC-13 } \\
\hline SR-90 & $1.73 E-04$ & & & $1.73 \mathrm{E}-04$ \\
\hline TRITIUM & 5.93E-05 & & $9.29 E-06$ & $6.86 \mathrm{E}-05$ \\
\hline Pathway Totals & $2.33 E-04$ & & $9.29 E-06$ & $2.42 E-04$ \\
\hline \multicolumn{5}{|l|}{ Residential, Seep WC-14 } \\
\hline SR-90 & $2.54 \mathrm{E}-04$ & & & $2.54 E-04$ \\
\hline TRITIUM & 7.06E-05 & & 1.11E-05 & 8.16E-05 \\
\hline Pathway Totals & $3.24 \mathrm{E}-04$ & & 1.11E-05 & $3.35 E-04$ \\
\hline \multicolumn{5}{|l|}{ Residential, Seep WC-15 } \\
\hline SR-90 & $2.27 \mathrm{E}-04$ & & & 2.27E-04 \\
\hline TRITIUM & $3.60 \mathrm{E}-05$ & & 5.64E-06 & 4.17E-05 \\
\hline Pathway Totals & $2.63 \mathrm{E}-04$ & & $5.64 \mathrm{E}-06$ & $2.68 \mathrm{E}-04$ \\
\hline \multicolumn{5}{|l|}{ Residential, Seep WC-16 } \\
\hline SR-90 & $1.78 \mathrm{E}-04$ & & & $1.78 E-04$ \\
\hline TRITIUM & 6.01E-06 & & 9.41E-07 & $6.95 E-06$ \\
\hline Pathway Totals & 1.84E-04 & & $9.41 \mathrm{E}-07$ & $1.85 \mathrm{E}-04$ \\
\hline \multicolumn{5}{|l|}{ Residential, Seep WC-17 } \\
\hline SR-90 & $1.38 \mathrm{E}-04$ & & & $1.38 E-04$ \\
\hline TRITIUM & $1.88 \mathrm{E}-05$ & & 2.95E-06 & 2.18E-05 \\
\hline Pathway Totals & 1.57E-04 & & 2.95E-06 & $1.60 \mathrm{E}-04$ \\
\hline \multicolumn{5}{|l|}{ Residential, Seep WC $=18$} \\
\hline SR-90 & $2.05 E-04$ & & & 2.05E-04 \\
\hline TRITIUM & $4.50 \mathrm{E}-06$ & . & 7.05E-07 & 5.21E-06 \\
\hline Pathway Totals & $2.10 \mathrm{E}-04$ & & $7.05 \mathrm{E}-07$ & $2.11 E-04$ \\
\hline \multicolumn{5}{|l|}{ Residential, Seep WC-19 } \\
\hline SR-90 & $1.78 \mathrm{E}-04$ & & & $1.78 \mathrm{E}-04$ \\
\hline TRITIUM & $4.50 \mathrm{E}-06$ & & 7.05E-07 & 5.21E-06 \\
\hline Pathway Totals & $1.83 \mathrm{E}-04$ & & 7.05E-07 & 1.84E-04 \\
\hline
\end{tabular}


Producel

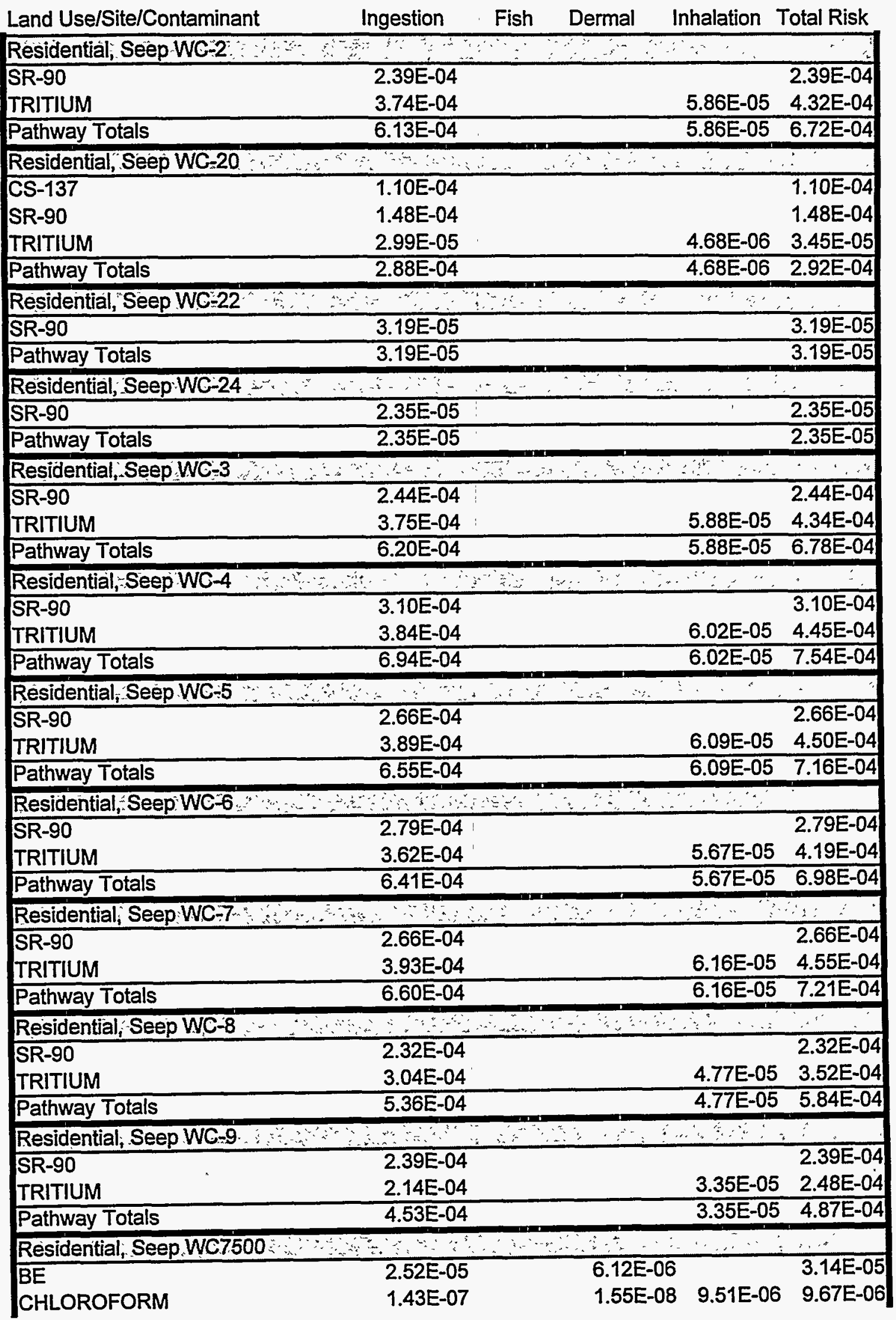




\begin{tabular}{|c|c|c|c|c|c|}
\hline Land Use/Site/Contaminant & Ingestion & $\begin{array}{c}\text { Producel } \\
\text { Fish }\end{array}$ & Dermal & Inhalation & Total Risk \\
\hline CS-137 & $7.42 E-05$ & & & & $7.42 \mathrm{E}-05$ \\
\hline SR-90 & 1.14E-04 & & & & 1.14E-04 \\
\hline TRITIUM & 2.00E-05 & & & 3.13E-06 & 2.31E-05 \\
\hline Pathway Totals & $2.33 \mathrm{E}-04$ & & $6.14 \mathrm{E}-06$ & $1.26 \mathrm{E}-05$ & $2.52 \mathrm{E}-04$ \\
\hline \multicolumn{6}{|l|}{ Residential, Seep WCHEAD } \\
\hline$\overline{B E}$ & $2.52 E-05$ & & $6.12 E-06$ & & $3.14 E-05$ \\
\hline SR-90 & 4.07E-05 & & & & 4.07E-05 \\
\hline TRITIUM & 3.19E-06 & & & 5.00E-07 & 3.69E-06 \\
\hline Pathway Totals & $6.92 E-05$ & & $6.12 E-06$ & $5.00 \mathrm{E}-07$ & $7.58 \mathrm{E}-05$ \\
\hline \multicolumn{6}{|l|}{ Residential, Seep WCTRIB $=1$} \\
\hline $\mathrm{BE}$ & $2.52 E-05$ & & $6.12 E-06$ & & 3.14E-05 \\
\hline $\operatorname{co-60}$ & 1.79E-05 & & & & 1.79E-05 \\
\hline CS-137 & 6.98E-06 & & & & $6.98 E-06$ \\
\hline SR-90 & 4.81E-05 & & & & 4.81E-05 \\
\hline TRITIUM & 2.13E-05 & & & 3.34E-06 & 2.47E-05 \\
\hline Pathway Totals & $1.20 \mathrm{E}-04$ & & $6.12 \mathrm{E}-06$ & $3.34 E-06$ & $1.29 E-04$ \\
\hline \multicolumn{6}{|l|}{ Residential, Seep WCTRIB-2 } \\
\hline$\overline{B E}$ & 2.52E-05 & & $6.12 \mathrm{E}-06$ & & 3.14E-05 \\
\hline TRITIUM & $4.50 \mathrm{E}-06$ & & & 7.05E-07 & 5.21E-06 \\
\hline Pathway Totals & 2.97E-05 & & $6.12 E-06$ & 7.05E-07 & $3.66 \mathrm{E}-05$ \\
\hline \multicolumn{6}{|l|}{ Residential, Seep WCTRIB-3 } \\
\hline$\overline{B E}$ & 3.03E-05 & & $7.35 E-06$ & & $3.76 \mathrm{E}-05$ \\
\hline CS-137 & 6.70E-06 & & & & $6.70 E-06$ \\
\hline SR-90 & 1.89E-03 & & & & 1.89E-03 \\
\hline TRITIUM & 3.62E-04 & & & 5.67E-05 & 4.19E-04 \\
\hline Pathway Totals & $2.29 \mathrm{E}-03$ & & 7.35E-06 & $5.67 \mathrm{E}-05$ & $2.35 E-03$ \\
\hline \multicolumn{6}{|l|}{ Residential, Seep WCTRIB-4 } \\
\hline$\overline{\mathrm{BE}}$ & 2.52E-05 & & 6.12E-06 & & 3.14E-05 \\
\hline CS-137 & 5.66E-06 & & & & 5.66E-06 \\
\hline SR-90 & 6.69E-05 & & & & 6.69E-05 \\
\hline TRITIUM & 1.50E-06 & & & 2.35E-07 & $1.74 E-06$ \\
\hline Pathway Totals & $9.93 \mathrm{E}-05$ & & $6.12 \mathrm{E}-06$ & 2.35E-07 & 1.06E-04 \\
\hline \multicolumn{6}{|l|}{ Residential, Seep WCWEIR } \\
\hline AS & $3.44 \mathrm{E}-05$ & & 2.04E-07 & & $3.46 \mathrm{E}-05$ \\
\hline$B E$ & 2.52E-05 & & $6.12 E-06$ & & 3.14E-05 \\
\hline CHLOROFORM & $6.45 E-08$ & & $6.96 E-09$ & $4.28 E-06$ & 4.35E-06 \\
\hline CS-137 & 4.16E-05 & & & & 4.16E-05 \\
\hline SR-90 & 1.83E-04 & & & & 1.83E-04 \\
\hline TRITIUM & $5.24 \mathrm{E}-05$ & & & 8.20E-06 & 6.06E-05 \\
\hline Pathway Totals & $3.36 E-04$ & & $6.33 \mathrm{E}-06$ & 1.25E-05 & 3.55E-04 \\
\hline \multicolumn{6}{|l|}{ Residential, Seep WEST SEEP } \\
\hline$\widehat{A S}$ & 1.06E-05 & & $6.25 E-08$ & & 1.06E-05 \\
\hline $\mathrm{BE}$ & 2.02E-05 & & $4.90 E-06$ & & 2.51E-05 \\
\hline $\mathrm{co}-60$ & $1.18 \mathrm{E}-05$ & & & & 1.18E-05 \\
\hline SR-90 & 1.93E-04 & & & & $1.93 E-04$ \\
\hline TRITIUM & 7.04E-05 & & & 1.10E-05 & $8.14 E-05$ \\
\hline
\end{tabular}




\begin{tabular}{|c|c|c|c|c|c|}
\hline Land Use/Site/Contaminant & Ingestion & $\begin{array}{l}\text { roduce/ } \\
\text { Fish }\end{array}$ & Dermal & Inhalation & Total Risk \\
\hline Pathway Totals & 3.06E-04 & & 4.96E-06 & $1.10 \mathrm{E}-05$ & $3.22 E-04$ \\
\hline Residential Seep WOCET & $\therefore \therefore$ & & & & . \\
\hline SR-90 & $2.79 \mathrm{E}-05$ & & & & 2.79E-05 \\
\hline TRITIUM & 1.73E-06 & & & 2.70E-07 & 2.00E-06 \\
\hline Pathway Totals & 2.97E-05 & & & $2.70 \mathrm{E}-07$ & 2.99E-05 \\
\hline Residential: Seep WOD & & & & $\cdots$ & \\
\hline$\overline{A S}$ & 1.06E-05 & & $6.25 E-08$ & & 1.06E-05 \\
\hline BE & 2.52E-05 & & 6.12E-06 & & $3.14 \mathrm{E}-05$ \\
\hline CHLOROFORM & 2.86E-08 & & 3.09E-09 & $1.90 E-06$ & 1.93E-06 \\
\hline CS-137 & 3.85E-05 & & & & 3.85E-05 \\
\hline SR-90 & 2.41E-04 & & & & 2.41E-04 \\
\hline TRITIUM & 2.73E-04 & & & 4.28E-05 & $3.16 \mathrm{E}-04$ \\
\hline Pathway Totals & $5.88 E-04$ & & 6.19E-06 & 4.47E-05 & $6.39 E-04$ \\
\hline Residential, Seep WS 1 . & 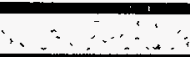 & & & & \\
\hline SR-90 & $2.09 \mathrm{E}-04$ & & & & 2.09E-04 \\
\hline TRITIUM & $3.56 \mathrm{E}-05$ & & & 5.57E-06 & 4.11E-05 \\
\hline Pathway Totals & $2.45 \mathrm{E}-04$ & & & 5.57E-06 & $2.50 \mathrm{E}-04$ \\
\hline Residential;,Seep WS-2 & 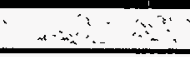 & & $\because \because \therefore$ & 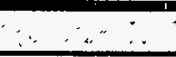 & \\
\hline $\mathrm{CO}-60$ & $3.82 E-05$ & & & & 3.82E-05 \\
\hline SR-90 & $6.63 E-04$ & & & & $6.63 E-04$ \\
\hline TRITIUM & 5.21E-05 & & & 8.16E-06 & $6.03 E-05$ \\
\hline Pathway Totals & 7.53E-04 & & & $8.16 \mathrm{E}-06$ & $7.62 \mathrm{E}-04$ \\
\hline Residential, Seep WS 3 & & & & $\because \because$ & $\therefore$ \\
\hline SR-90 & $2.68 E-04$ & & & & 2.68E-04 \\
\hline TRITIUM & $1.65 \mathrm{E}-05$ & & & $2.58 \mathrm{E}-06$ & $1.90 \mathrm{E}-05$ \\
\hline Pathway Totals & $2.84 E-04$ & & & $2.58 E-06$ & 2.87E-04 \\
\hline Rèsidential, Seep WSTRIB 1 & & & & $\because$ & \\
\hline $\mathrm{BE}$ & $1.51 \mathrm{E}-05$ & & 3.67E-06 & & $1.88 \mathrm{E}-05$ \\
\hline $\mathrm{CO}-60$ & 1.64E-05 & & & & 1.64E-05 \\
\hline CS-137 & 3.05E-06 & & & & 3.05E-06 \\
\hline SR-90 & 2.69E-04 & & & & 2.69E-04 \\
\hline TRITIUM & $6.58 \mathrm{E}-05$ & & & $1.03 \mathrm{E}-05$ & 7.61E-05 \\
\hline Pathway Totals & 3.69E-04 & & 3.67E-06 & $1.03 \mathrm{E}-05$ & 3.83E-04 \\
\hline
\end{tabular}




\section{APPENDIX F}

NONCARCINOGENIC HAZARD TABLES FOR THE SEEPS TASK DATA USED IN THE WAG 2 ASSESSMENT 
Produce/

\begin{tabular}{|c|c|c|c|c|c|}
\hline Land Use/Site/Contaminant & Ingestion & Fish & Dermal & Inhalation & Total HI \\
\hline \multicolumn{6}{|l|}{ Recreational, Seep 05.SP014 } \\
\hline$\overline{M N}$ & $2.20 \mathrm{E}-03$ & $1.00 \mathrm{E}+00$ & $2.10 \mathrm{E}-02$ & & $1.02 E+00$ \\
\hline 1,1-DICHLOROETHENE & $9.80 E-05$ & $1.50 \mathrm{E}-03$ & $3.40 \mathrm{E}-04$ & & $1.98 E-03$ \\
\hline 1,2-DICHLOROETHENE (TOTAL) & 8.30E-03 & $1.30 \mathrm{E}-02$ & $4.30 E-03$ & & 2.57E-02 \\
\hline CHLOROFORM & $1.80 \mathrm{E}-05$ & 4.00E-04 & $3.00 E-04$ & & 7.17E-04 \\
\hline TETRACHLOROETHENE & 2.60E-04 & $1.60 \mathrm{E}-02$ & 3.70E-02 & & 5.33E-02 \\
\hline Pathway Totals & $1.10 \mathrm{E}-02$ & $1.00 \mathrm{E}+00$ & $6.30 \mathrm{E}-02$ & & $1.10 \mathrm{E}+00$ \\
\hline \multicolumn{6}{|l|}{ Recreational, Seep 05:SP015 } \\
\hline FLUORIDE & $9.10 E-04$ & & $3.60 \mathrm{E}-04$ & & $1.27 \mathrm{E}-03$ \\
\hline MN & $1.50 \mathrm{E}-02$ & $6.90 \mathrm{E}+00$ & $1.40 E-01$ & & $7.03 E+00$ \\
\hline $\mathrm{NI}$ & 1.40E-03 & 1.70E-01 & 2.10E-03 & & 1.70E-01 \\
\hline SE & $6.30 \mathrm{E}-04$ & & 5.50E-04 & & 1.18E-03 \\
\hline Pathway Totals & $1.80 \mathrm{E}-02$ & $7.00 \mathrm{E}+00$ & $1.50 \mathrm{E}-01$ & & $7.20 \mathrm{E}+00$ \\
\hline \multicolumn{6}{|l|}{ Recreational, Seep 05.SP016 } \\
\hline CR & $3.00 \mathrm{E}-04$ & $7.00 \mathrm{E}-02$ & 5.90E-03 & & $\overline{7.60 E-02}$ \\
\hline $\mathrm{MN}$ & 1.90E-03 & 8.90E-01 & $1.90 \mathrm{E}-02$ & & 9.08E-01 \\
\hline Pathway Totals & $2.20 \mathrm{E}-03$ & $9.60 \mathrm{E}-01$ & $2.50 \mathrm{E}-02$ & & $9.84 \mathrm{E}-01$ \\
\hline \multicolumn{6}{|l|}{ Recreational, Seep 05.SP017 } \\
\hline AS & 1.10E-03 & & 1.00E-03 & & 2.06E-03 \\
\hline MN & $1.90 \mathrm{E}-02$ & $8.60 \mathrm{E}+00$ & 1.80E-01 & & $8.84 E+00$ \\
\hline SB & $6.10 E-03$ & 7.00E-01 & $1.20 E-01$ & & 8.27E-01 \\
\hline Pathway Totals & $2.60 \mathrm{E}-02$ & $9.30 \mathrm{E}+00$ & $3.00 \mathrm{E}-01$ & & $9.66 \mathrm{E}+00$ \\
\hline \multirow{2}{*}{\multicolumn{6}{|c|}{$\begin{array}{l}\text { Recreational, Seep 05.SW001 } \\
\text { Pathway Totals }\end{array}$}} \\
\hline & & & & & \\
\hline \multicolumn{6}{|l|}{ Recreational, Seep 05. SW002 } \\
\hline$\overline{A S}$ & $3.60 \mathrm{E}-04$ & & $3.40 E-04$ & & $7.02 E-04$ \\
\hline $\mathrm{MN}$ & 5.70E-03 & 2.60E+00 & 5.50E-02 & & $2.69 E+00$ \\
\hline BIS(2-ETHYLHEXYL) PHTHALATE & 2.60E-05 & $9.50 E-02$ & 1.30E-03 & & $9.62 E-02$ \\
\hline Pathway Totals & $6.10 \mathrm{E}-03$ & $2.70 E+00$ & $5.70 \mathrm{E}-02$ & & $2.78 E+00$ \\
\hline \multicolumn{6}{|l|}{ Recreational, Seep 05.SW003 } \\
\hline$\overline{M N}$ & $5.00 \mathrm{E}-04$ & $2.30 \mathrm{E}-01$ & 4.80E-03 & & 2.36E-01 \\
\hline Pathway Totals & 5.00E-04 & 2.30E-01 & 4.80E-03 & & $2.36 \mathrm{E}-01$ \\
\hline \multicolumn{6}{|l|}{ Recreational, Seep 05.SW004 } \\
\hline FLUORIDE & 7.70E-04 & & 3.10E-04 & & $1.08 \mathrm{E}-03$ \\
\hline Pathway Totals & $7.70 \mathrm{E}-04$ & & 3.10E-04 & & 1.08E-03 \\
\hline \multicolumn{6}{|l|}{ Recreational, Seep 05.SW005 } \\
\hline FLUORIDE & $2.60 E-03$ & & 1.10E-03 & & 3.70E-03 \\
\hline BIS(2-ETHYLHEXYL) PHTHALATE & $1.60 E-04$ & 5.70E-01 & 7.60E-03 & & 5.77E-01 \\
\hline Pathway Totals & 2.80E-03 & $5.70 \mathrm{E}-01$ & $8.60 \mathrm{E}-03$ & & 5.81E-01 \\
\hline \multicolumn{6}{|l|}{ Recreational, Seep 05.SW006 } \\
\hline FLUORIDE & $2.00 \mathrm{E}-03$ & & $.7 .90 \mathrm{E}-04$ & & 2.77E-03 \\
\hline Pathway Totals & $2.00 E-03$ & & $7.90 \mathrm{E}-04$ & & 2.77E-03 \\
\hline \multicolumn{6}{|l|}{ Recreational, Seep 5NNT } \\
\hline $\mathrm{BE}$ & 7.00E-06 & 8.10E-04 & 2.70E-04 & & $1.09 E-03$ \\
\hline FLUORIDE & 5.90E-04 & & 2.30E-04 & & 8.22E-04 \\
\hline V & 3.00E-04 & $3.50 \mathrm{E}-03$ & $1.20 \mathrm{E}-02$ & & $1.56 \mathrm{E}-02$ \\
\hline
\end{tabular}




\begin{tabular}{|c|c|c|c|c|c|}
\hline Land Use/Site/Contaminant & Ingestion & $\begin{array}{c}\text { Producel } \\
\text { Fish }\end{array}$ & Dermal & Inhalation & Total HI \\
\hline CARBON DISULFIDE & $1.20 \mathrm{E}-04$ & $3.90 \mathrm{E}-03$ & $1.80 E-03$ & & $5.88 \mathrm{E}-03$ \\
\hline METHYLENE CHLORIDE & 1.90E-05 & 1.30E-04 & $3.50 \mathrm{E}-05$ & & $1.80 \mathrm{E}-04$ \\
\hline Pathway Totals & 1.00E-03 & $8.40 \mathrm{E}-03$ & $1.40 \mathrm{E}-02$ & & $2.36 \mathrm{E}-02$ \\
\hline \multicolumn{6}{|l|}{ Recreational:'Seep 5NST } \\
\hline$\overline{B E}$ & $1.10 \mathrm{E}-05$ & $1.20 \mathrm{E}-03$ & 4.10E-04 & & 1.64E-03 \\
\hline$M N$ & 3.10E-04 & 1.40E-01 & $3.00 E-03$ & & $1.47 \mathrm{E}-01$ \\
\hline V & 4.10E-04 & $4.70 \mathrm{E}-03$ & $1.60 \mathrm{E}-02$ & & 2.08E-02 \\
\hline Pathway Totals & $7.30 \mathrm{E}-04$ & $1.50 \mathrm{E}-01$ & 1.90E-02 & & $1.69 \mathrm{E}-01$ \\
\hline \multicolumn{6}{|l|}{ Recreational, Seep $5 \mathrm{NW}-1$} \\
\hline $\mathrm{BE}$ & 8.80E-06 & $1.00 \mathrm{E}-03$ & $3.40 \mathrm{E}-04$ & & $1.36 \mathrm{E}-03$ \\
\hline MN & $1.70 \mathrm{E}-03$ & 8.00E-01 & 1.70E-02 & & $8.20 \mathrm{E}-01$ \\
\hline V & $3.40 \mathrm{E}-04$ & $3.90 E-03$ & 1.30E-02 & & $1.75 E-02$ \\
\hline Pathway Totals & $2.10 E-03$ & $8.10 \mathrm{E}-01$ & $3.00 \mathrm{E}-02$ & & $8.39 \mathrm{E}-01$ \\
\hline \multicolumn{6}{|l|}{ Recreational, Seep 5NW-2. } \\
\hline $\mathrm{BE}$ & $8.80 \mathrm{E}-06$ & $1.00 \mathrm{E}-03$ & $3.40 E-04$ & & $1.36 \mathrm{E}-03$ \\
\hline MN & $1.00 \mathrm{E}-02$ & $4.60 E+00$ & $9.80 E-02$ & & $4.74 E+00$ \\
\hline V & 3.20E-04 & 3.70E-03 & $1.20 \mathrm{E}-02$ & & 1.63E-02 \\
\hline Pathway Totals & 1.00E-02 & $4.60 E+00$ & 1.10E-01 & & $4.76 E+00$ \\
\hline \multicolumn{6}{|c|}{ Recreational, Seep BTT } \\
\hline $\mathrm{BA}$ & $3.90 \mathrm{E}-04$ & $1.80 \mathrm{E}-03$ & $2.20 E-03$ & & $4.35 \mathrm{E}-03$ \\
\hline$B E$ & 1.10E-05 & 1.20E-03 & 4.20E-04 & & 1.66E-03 \\
\hline FLUORIDE & $3.80 E-04$ & & 1.50E-04 & & 5.34E-04 \\
\hline MO & $1.80 \mathrm{E}-03$ & $2.10 \mathrm{E}-02$ & $1.80 E-03$ & & 2.42E-02 \\
\hline Pathway Totals & $2.60 \mathrm{E}-03$ & $2.40 \mathrm{E}-02$ & 4.60E-03 & & 3.07E-02 \\
\hline \multicolumn{6}{|l|}{ Recreational,-Seep EAST SEEP } \\
\hline$\overline{A S}$ & 1.00E-03 & & $9.60 \mathrm{E}-04$ & & $1.98 \mathrm{E}-03$ \\
\hline BE & 8.80E-06 & $1.00 E-03$ & 3.40E-04 & & 1.36E-03 \\
\hline CR & $4.50 E-04$ & $1.00 E-01$ & 8.80E-03 & & 1.14E-01 \\
\hline FLUORIDE & $1.80 \mathrm{E}-03$ & & 7.00E-04 & & 2.47E-03 \\
\hline MN & 7.30E-04 & $3.40 E-01$ & 7.10E-03 & & $3.46 E-01$ \\
\hline NITRATE & $1.00 \mathrm{E}-03$ & & 8.10E-04 & & $1.86 \mathrm{E}-03$ \\
\hline Pathway Totals & $5.00 \mathrm{E}-03$ & $4.40 \mathrm{E}-01$ & $1.90 E-02$ & & $4.68 E-01$ \\
\hline \multirow{2}{*}{\multicolumn{6}{|c|}{$\begin{array}{l}\text { Recreational; Seep FC-1 } \\
\text { Pathway Totals }\end{array}$}} \\
\hline & & & & & \\
\hline \multicolumn{6}{|c|}{ Recreational, Seep FIFTH CREEK } \\
\hline \multicolumn{6}{|c|}{ Pathway Totals } \\
\hline \multicolumn{6}{|c|}{ Recreátional, Seep FIRST CREEK } \\
\hline$\overline{B E}$ & $2.30 \mathrm{E}-06$ & $2.60 E-04$ & $8.90 E-05$ & & 3.55E-04 \\
\hline FLUORIDE & $1.50 E-03$ & & 5.90E-04 & & 2.05E-03 \\
\hline CHLOROFORM & $3.50 E-06$ & $7.90 E-05$ & $6.10 E-05$ & & 1.43E-04 \\
\hline Pathway Totals & $1.50 \mathrm{E}-03$ & $3.40 \mathrm{E}-04$ & $7.40 \mathrm{E}-04$ & & 2.55E-03 \\
\hline \multicolumn{6}{|c|}{ Recreational, Seep FRENCH DR S } \\
\hline 1,1-DICHLOROETHENE & $2.00 \mathrm{E}-06$ & $3.10 \mathrm{E}-05$ & $6.80 E-06$ & & 3.97E-05 \\
\hline CHLOROFORM & 3.50E-06 & $7.90 \mathrm{E}-05$ & $6.10 E-05$ & & 1.43E-04 \\
\hline CIS-1,2-DICHLOROE & $1.80 \mathrm{E}-03$ & $3.50 \mathrm{E}-02$ & 7.20E-03 & & 4.39E-02 \\
\hline TETRACHLOROETHENE & $8.70 E-04$ & $5.60 \mathrm{E}-02$ & 1.30E-01 & & $1.82 \mathrm{E}-01$ \\
\hline
\end{tabular}


Producel

Land Use/Site/Contaminant

Ingestion

Fish

Dermal Inhalation Total $\mathrm{HI}$

Pathway Totals

2.70E-03

9.10E-02 1.30E-01

2.26E-01

Recreational, Seep FRENCH DRAIN

NITRATE

Pathway Totals

4.70E-04

$4.70 \mathrm{E}-04$

3.60E-04

3.60E-04

8.31E-04

Recreational, Seep HRT-10

Pathway Totals

Recreational, Seep HRT-1A

Pathway Totals

Recreational, Seep HRT-1B

Pathway Totals

Recreational, Seep HRT-1C

Pathway Totals

Recreational, Seep HRT-1D

Pathway Totals

Recreational, Seep HRT-2

Pathway Totals

Recreational, Seep HRT-2A

Pathway Totals

Recreational, Seep HRT-3

AS

BE

FLUORIDE

1.60E-04

1.50E-04

3.14E-04

4.90E-06 5.70E-04 1.90E-04

7.64E-04

$S B$

7.30E-04

2.90E-04

1.03E-03

Pathway Totals

4.20E-03 4.80E-01 8.20E-02

5.70E-01

Recreational, Seep HRT-4

5.10E-03 $4.80 \mathrm{E}-01 \quad 8.20 \mathrm{E}-02$

5.72E-01

Pathway Totals

Recreational, Seep HRT-5

Pathway Totals

Recreational, Seep HRT-6

Pathway Totals

Recreational, Seep.HRT-7

Pathway Totals

Recreational, Seep HRT-8

Pathway Totals

Recreational, Seep HRT-9

Pathway Totals

Recreational, Seep MB-1

AS

BE

5.30E-04

5.00E-04

1.03E-03

Pathway Totals

2.00E-05

5.50E-04

2.40E-03

7.90E-04

3.17E-03

Recreational, Seep MB-10

Pathway Totals

Recreational, Seep MB-11

Pathway Totals

Recreational, Seep MB-12 


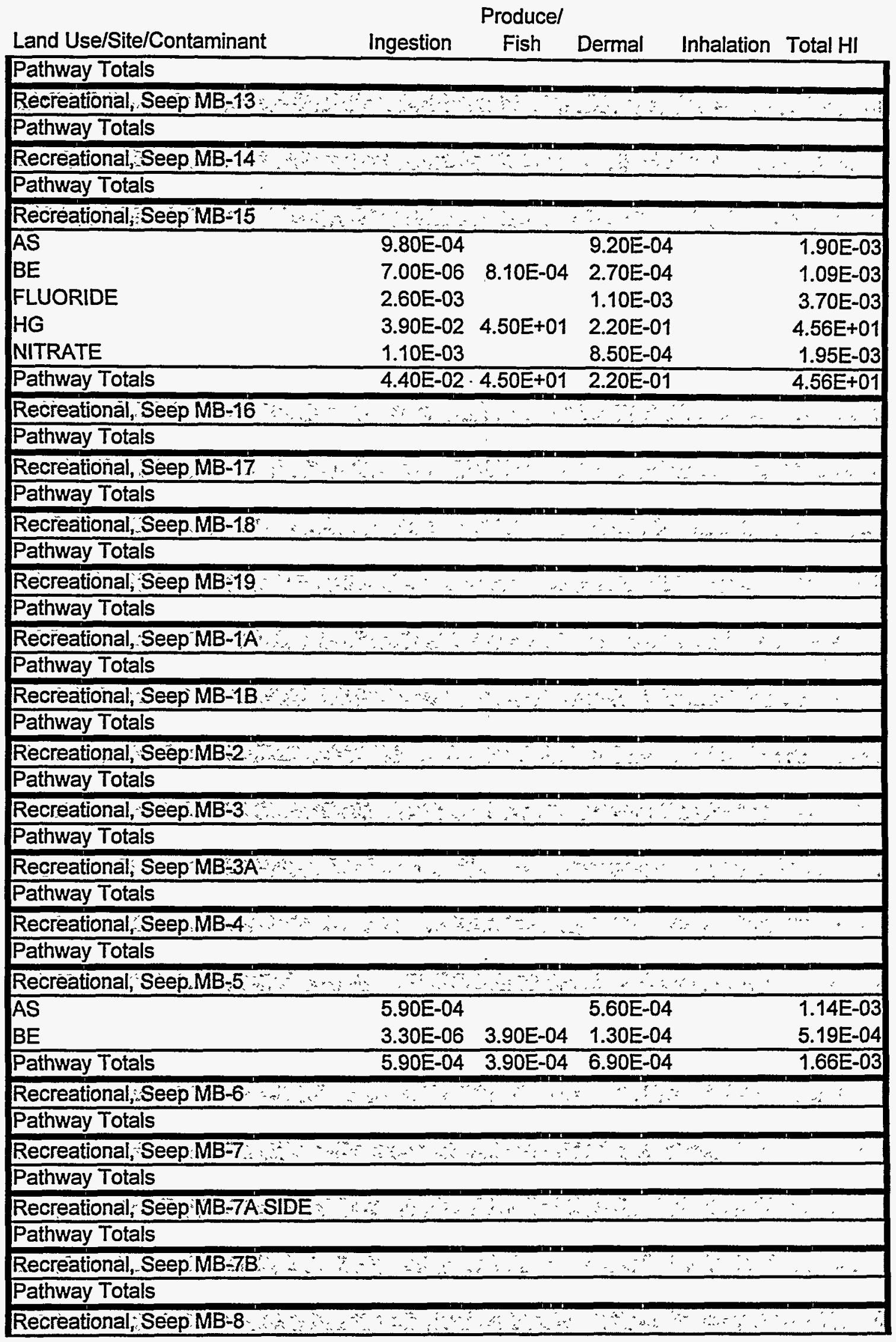


Producel

\begin{tabular}{|c|c|c|c|c|}
\hline Land Use/Site/Contaminant & Ingestion & Fish & Inhalation & Total HI \\
\hline \multicolumn{5}{|l|}{ Pathway Totals } \\
\hline \multicolumn{5}{|l|}{ Recreational, Seep MB-9. } \\
\hline \multicolumn{5}{|l|}{ Pathway Totals } \\
\hline \multicolumn{5}{|l|}{ Recreational, Seep MBTRIB-1. } \\
\hline \multicolumn{5}{|l|}{ Pathway Totals } \\
\hline \multicolumn{5}{|l|}{ Recreational, Seep MBTRIB-2A. } \\
\hline \multicolumn{5}{|l|}{ Pathway Totals } \\
\hline \multicolumn{5}{|l|}{ Recreational, Seep MBTRIB-2B } \\
\hline \multicolumn{5}{|l|}{ Pathway Totals } \\
\hline \multicolumn{5}{|l|}{ Recreational, Seep MBTRIB-3 } \\
\hline MN & $9.50 \mathrm{E}-04$ & $4.40 \mathrm{E}-01$ & $9.20 E-03$ & $4.49 E-01$ \\
\hline CHLOROFORM & $5.30 \mathrm{E}-05$ & $1.20 E-03$ & $9.10 E-04$ & 2.15E-03 \\
\hline Pathway Totals & $1.00 \mathrm{E}-03$ & $4.40 \mathrm{E}-01$ & $1.00 \mathrm{E}-02$ & $4.51 E-01$ \\
\hline \multicolumn{5}{|l|}{ Recreational, Seep MBWEIR } \\
\hline$\overline{A S}$ & $6.60 \mathrm{E}-04$ & & $6.30 E-04$ & $1.29 E-03$ \\
\hline$B E$ & 8.80E-06 & $1.00 E-03$ & 3.40E-04 & $1.36 \mathrm{E}-03$ \\
\hline FLUORIDE & $1.90 E-03$ & & 7.60E-04 & 2.65E-03 \\
\hline MN & $3.40 \mathrm{E}-04$ & $1.50 E-01$ & 3.30E-03 & $1.58 \mathrm{E}-01$ \\
\hline NITRATE & 9.90E-04 & & 7.70E-04 & 1.75E-03 \\
\hline SB & 4.20E-03 & 4.80E-01 & $8.20 E-02$ & 5.70E-01 \\
\hline Pathway Totals & 8.10E-03 & $6.40 \mathrm{E}-01$ & 8.70E-02 & $7.35 \mathrm{E}-01$ \\
\hline \multicolumn{5}{|l|}{ Recreational, Seep MID. DRAIN. } \\
\hline AS & $2.30 E-04$ & & $2.20 \mathrm{E}-04$ & 4.57E-04 \\
\hline BE & 5.30E-06 & $6.10 E-04$ & 2.10E-04 & 8.19E-04 \\
\hline MN & 6.20E-03 & $2.80 E+00$ & $6.00 \mathrm{E}-02$ & $2.90 E+00$ \\
\hline Pathway Totals & $6.40 \mathrm{E}-03$ & $2.80 E+00$ & $6.00 \mathrm{E}-02$ & $2.90 E+00$ \\
\hline \multicolumn{5}{|l|}{ Recreational, Seep.MV-1 } \\
\hline$\overline{\mathrm{AS}}$ & $6.80 E-04$ & & $6.40 E-04$ & 1.31E-03 \\
\hline MN & 7.50E-03 & $3.50 E+00$ & 7.30E-02 & $3.55 E+00$ \\
\hline Pathway Totals & $8.20 \mathrm{E}-03$ & $3.50 E+00$ & $7.40 \mathrm{E}-02$ & $3.55 E+00$ \\
\hline \multicolumn{5}{|l|}{ Recreational, Seep MV-3 } \\
\hline \multicolumn{5}{|l|}{ Pathway Totals } \\
\hline \multicolumn{5}{|l|}{ Recreational, Seep NON RAD OU } \\
\hline \multicolumn{5}{|l|}{ Pathway Totals } \\
\hline \multicolumn{5}{|l|}{ Recreational, Seep NWTRIB } \\
\hline $\mathrm{BE}$ & $8.80 E-06$ & $1.00 \mathrm{E}-03$ & $3.40 \mathrm{E}-04$ & $1.36 \mathrm{E}-03$ \\
\hline FLUORIDE & 7.30E-04 & & 2.90E-04 & 1.03E-03 \\
\hline $\mathrm{v}$ & 3.10E-04 & 3.60E-03 & 1.20E-02 & 1.59E-02 \\
\hline Pathway Totals & $1.10 \mathrm{E}-03$ & $4.60 \mathrm{E}-03$ & $1.30 \mathrm{E}-02$ & $1.83 \mathrm{E}-02$ \\
\hline \multicolumn{5}{|l|}{ Recreational, Seep R-227. } \\
\hline \multicolumn{5}{|l|}{ Pathway Totals } \\
\hline \multicolumn{5}{|l|}{ Recreational, Seep R-311 } \\
\hline $\mathrm{BE}$ & $4.90 \mathrm{E}-06$ & $5.70 \mathrm{E}-04$ & $1.90 \mathrm{E}-04$ & $7.64 \mathrm{E}-04$ \\
\hline $\mathrm{CD}$ & 3.30E-04 & 7.70E-02 & $1.30 \mathrm{E}-02$ & 8.98E-02 \\
\hline Pathway Totals & $3.40 \mathrm{E}-04$ & $7.70 E-02$ & $1.30 \mathrm{E}-02$ & $9.06 \mathrm{E}-02$ \\
\hline
\end{tabular}




\begin{tabular}{|c|c|c|c|c|c|}
\hline Land Use/Site/Contaminant & Ingestion & $\begin{array}{c}\text { Producel } \\
\text { Fish }\end{array}$ & Dermal & Inhalation & Total HI \\
\hline \multicolumn{6}{|l|}{ Recireational; Seep RAC } \\
\hline$\overline{\mathrm{MN}}$ & $2.80 \mathrm{E}-03$ & $1.30 E+00$ & $2.70 E-02$ & & $1.30 \mathrm{E}+00$ \\
\hline Pathway Totals & $2.80 E-03$ & $1.30 E+00$ & $2.70 \mathrm{E}-02$ & & $1.30 \mathrm{E}+00$ \\
\hline \multicolumn{6}{|l|}{ Recreational, Seep RS-1 } \\
\hline AS & $3.70 E-03$ & & $3.50 E-03$ & & $7.12 E-03$ \\
\hline$B E$ & 7.00E-06 & 8.10E-04 & 2.70E-04 & & $1.09 E-03$ \\
\hline MN & 1.20E-02 & $5.50 \mathrm{E}+00$ & 1.20E-01 & & $5.64 E+00$ \\
\hline Pathway Totals & $1.60 \mathrm{E}-02$ & $5.50 E+00$ & $1.20 \mathrm{E}-01$ & & $5.65 E+00$ \\
\hline \multicolumn{6}{|l|}{ Recreational, Seep RS-3 } \\
\hline AS & $6.50 \mathrm{E}-03$ & & $6.10 \mathrm{E}-03$ & & 1.26E-02 \\
\hline$B E$ & 7.00E-06 & 8.10E-04 & 2.70E-04 & & $1.09 E-03$ \\
\hline CR & $1.10 E-03$ & 2.60E-01 & 2.20E-02 & & 2.83E-01 \\
\hline FLUORIDE & 1.60E-02 & & $6.50 E-03$ & & 2.26E-02 \\
\hline MO & $7.20 E-04$ & 8.30E-03 & 7.40E-04 & & $9.78 \mathrm{E}-03$ \\
\hline NI & 4.00E-04 & 4.60E-02 & 5.80E-04 & & 4.71E-02 \\
\hline NITRATE & $4.20 E-03$ & & 3.30E-03 & & 7.53E-03 \\
\hline SB & $1.80 \mathrm{E}-03$ & 2.00E-01 & $3.40 E-02$ & & 2.39E-01 \\
\hline V & $3.20 \mathrm{E}-04$ & 3.70E-03 & 1.20E-02 & & 1.63E-02 \\
\hline Pathway Totals & $3.10 \mathrm{E}-02$ & $5.20 \mathrm{E}-01$ & $8.60 \mathrm{E}-02$ & & $6.39 E-01$ \\
\hline \multicolumn{6}{|l|}{ Recreational, SeepRS-3A } \\
\hline$\overline{A S}$ & $5.90 E-03$ & & 5.60E-03 & & 1.14E-02 \\
\hline$B E$ & 1.60E-05 & 1.80E-03 & 6.00E-04 & & 2.41E-03 \\
\hline CD & 3.00E-04 & 7.00E-02 & 1.20E-02 & & 8.15E-02 \\
\hline CR & 1.50E-03 & 3.40E-01 & 2.90E-02 & & $3.70 E-01$ \\
\hline N & $6.30 \mathrm{E}-04$ & 2.90E-01 & $6.10 \mathrm{E}-03$ & & $.2 .95 E-01$ \\
\hline MO & $9.10 E-04$ & 1.10E-02 & 9.30E-04 & & 1.24E-02 \\
\hline NI & $4.50 E-04$ & 5.20E-02 & 6.50E-04 & & 5.34E-02 \\
\hline V & 3.40E-04 & 3.90E-03 & $1.30 E-02$ & & $1.72 \mathrm{E}-02$ \\
\hline Pathway Totals & $1.00 \mathrm{E}-02$ & $7.70 \mathrm{E}-01$ & 6.70E-02 & & $8.44 \mathrm{E}-01$ \\
\hline \multicolumn{6}{|c|}{ Recreational, Seep $R S-3 B$} \\
\hline CARBON DISULFIDE & $2.30 \mathrm{E}-04$ & 7.30E-03 & $3.40 \mathrm{E}-03$ & & 1.09E-02 \\
\hline Pathway Totals & $2.30 E-04$ & $7.30 \mathrm{E}-03$ & $3.40 \mathrm{E}-03$ & & 1.09E-02 \\
\hline \multicolumn{6}{|c|}{ Recreatiōnal; Seep:SPD } \\
\hline AS & $6.50 E-04$ & & 6.10E-04 & & $1.26 \mathrm{E}-03$ \\
\hline $\mathrm{BA}$ & 5.10E-04 & 2.30E-03 & 2.80E-03 & & 5.65E-03 \\
\hline$B E$ & 2.50E-06 & 2.80E-04 & $9.60 \mathrm{E}-05$ & & 3.82E-04 \\
\hline MN & $9.20 E-03$ & $4.20 E+00$ & 8.90E-02 & & $4.32 E+00$ \\
\hline Pathway Totals & 1.00E-02 & $4.20 E+00$ & $9.20 \mathrm{E}-02$ & & $4.33 E+00$ \\
\hline \multicolumn{6}{|l|}{ Recreational, Seep SW2-1 } \\
\hline$B E$ & 7.00E-06 & 8.10E-04 & 2.70E-04 & & 1.09E-03 \\
\hline MN & 3.80E-03 & $1.70 E+00$ & 3.70E-02 & & $1.79 E+00$ \\
\hline N DISULFIDE & 1.10E-04 & 3.40E-03 & $1.60 \mathrm{E}-03$ & & $5.04 E-03$ \\
\hline Pathway Totals & $3.90 E-03$ & $1.80 E+00$ & $3.90 \mathrm{E}-02$ & & $1.79 \mathrm{E}+00$ \\
\hline \multicolumn{6}{|l|}{ Recreational; Seep SW2:2 } \\
\hline & 1.10E-05 & $1.20 \mathrm{E}-03$ & $4.10 E-04$ & & $1.64 \mathrm{E}-03$ \\
\hline FLUORIDE & 4.10E-04 & & 1.60E-04 & & $5.75 \mathrm{E}-0$ \\
\hline
\end{tabular}




\begin{tabular}{|c|c|c|c|c|c|}
\hline & & Produce/ & & & \\
\hline Land Use/Site/Contaminant & Ingestion & Fish & Dermal & Inhalation & Total HI \\
\hline MN & $1.90 \mathrm{E}-03$ & $8.60 \mathrm{E}-01$ & $1.80 \mathrm{E}-02$ & & 8.77E-01 \\
\hline V & 3.80E-04 & $4.40 E-03$ & $1.50 \mathrm{E}-02$ & & $1.95 E-02$ \\
\hline Pathway Totals & $2.70 \mathrm{E}-03$ & $8.60 E-01$ & $3.30 E-02$ & & $8.99 \mathrm{E}-01$ \\
\hline Recreational, Seep SW2-3 & $\therefore$ & & & & \\
\hline$\overline{B E}$ & $8.80 \mathrm{E}-06$ & $1.00 \mathrm{E}-03$ & 3.40E-04 & & $1.36 \mathrm{E}-03$ \\
\hline V & $3.20 \mathrm{E}-04$ & 3.60E-03 & $1.20 \mathrm{E}-02$ & & $1.62 E-02$ \\
\hline Pathway Totals & $3.20 \mathrm{E}-04$ & $4.70 \mathrm{E}-03$ & $1.30 \mathrm{E}-02$ & & $1.76 \mathrm{E}-02$ \\
\hline Recreational, Seep SW2-4 & & & & & \\
\hline AS & 8.80E-04 & & 8.30E-04 & & 1.71E-03 \\
\hline MN & 2.00E-02 & $9.20 \mathrm{E}+00$ & $1.90 \mathrm{E}-01$ & & $9.43 E+00$ \\
\hline Pathway Totals & $2.10 \mathrm{E}-02$ & $9.20 E+00$ & $1.90 \mathrm{E}-01$ & & $9.43 E+00$ \\
\hline Recreational, Seep SW2-5 & & & & & \\
\hline$\overline{\mathrm{BA}}$ & $3.80 \mathrm{E}-04$ & $1.80 \mathrm{E}-03$ & $2.10 \mathrm{E}-03$ & & 4.29E-03 \\
\hline $\mathrm{BE}$ & $3.00 \mathrm{E}-06$ & $3.40 \mathrm{E}-04$ & $1.20 \mathrm{E}-04$ & & $4.64 E-04$ \\
\hline MN & $2.30 \mathrm{E}-03$ & $1.10 E+00$ & 2.30E-02 & & $1.11 E+00$ \\
\hline CARBON DISULFIDE & $2.10 \mathrm{E}-04$ & $6.70 \mathrm{E}-03$ & $3.10 \mathrm{E}-03$ & & 1.01E-02 \\
\hline Pathway Totals & $2.90 \mathrm{E}-03$ & $1.10 \mathrm{E}+00$ & $2.80 \mathrm{E}-02$ & & $1.12 \mathrm{E}+00$ \\
\hline Recreational, Seep SW2-6 & & & & & \\
\hline$\overline{A S}$ & $2.90 \mathrm{E}-04$ & & $2.80 \mathrm{E}-04$ & & 5.71E-04 \\
\hline $\mathrm{BE}$ & $3.00 \mathrm{E}-06$ & $3.40 \mathrm{E}-04$ & $1.20 \mathrm{E}-04$ & & $4.64 \mathrm{E}-04$ \\
\hline MN & 2.60E-03 & $1.20 E+00$ & 2.50E-02 & & $1.21 E+00$ \\
\hline Pathway Totals & $2.90 \mathrm{E}-03$ & $1.20 \mathrm{E}+00$ & $2.50 \mathrm{E}-02$ & & $1.21 \mathrm{E}+00$ \\
\hline Recreational, Seep SW2-7 & & & & & \\
\hline$\overline{\mathrm{AS}}$ & $4.10 \mathrm{E}-04$ & & 3.90E-04 & & $8.00 E-04$ \\
\hline $\mathrm{BE}$ & 5.10E-06 & $5.90 \mathrm{E}-04$ & 2.00E-04 & & 7.92E-04 \\
\hline MN & $3.60 \mathrm{E}-03$ & $1.70 E+00$ & $3.50 \mathrm{E}-02$ & & $1.69 \mathrm{E}+00$ \\
\hline Pathway Totals & 4.00E-03 & $1.70 E+00$ & $3.50 \mathrm{E}-02$ & & $1.69 E+00$ \\
\hline Recreational, Seep SW4-1 & & & & & \\
\hline AS & $1.80 \mathrm{E}-03$ & & 1.70E-03 & & 3.54E-03 \\
\hline$B A$ & 6.70E-04 & $3.10 E-03$ & 3.70E-03 & & 7.49E-03 \\
\hline $\mathrm{BE}$ & $1.40 E-05$ & $1.60 \mathrm{E}-03$ & 5.50E-04 & & 2.18E-03 \\
\hline FLUORIDE & 2.30E-02 & & 9.20E-03 & & 3.23E-02 \\
\hline MN & 7.00E-03 & $3.20 E+00$ & $6.80 E-02$ & & $3.28 E+00$ \\
\hline SB & $9.40 \mathrm{E}-03$ & $1.10 \mathrm{E}+00$ & 1.80E-01 & & $1.28 E+00$ \\
\hline V & $2.80 \mathrm{E}-04$ & $3.30 E-03$ & 1.10E-02 & & $1.45 \mathrm{E}-02$ \\
\hline 1,1-DICHLOROETHENE & 4.90E-06 & $7.70 \mathrm{E}-05$ & 1.70E-05 & & 9.92E-05 \\
\hline CIS-1,2-DICHLOROETHENE & 4.40E-04 & 8.30E-03 & 1.70E-03 & & 1.05E-02 \\
\hline Pathway Totals & $4.30 \mathrm{E}-02$ & $4.30 \mathrm{E}+00$ & $2.80 \mathrm{E}-01$ & & $4.63 E+00$ \\
\hline Recreational, Seep SW4-2 & & & 6 & & \\
\hline $\mathrm{BA}$ & 5.50E-04 & 2.50E-03 & $3.10 \mathrm{E}-03$ & & $6.14 E-03$ \\
\hline $\mathrm{BE}$ & 1.10E-05 & 1.30E-03 & 4.30E-04 & & 1.72E-03 \\
\hline$M N$ & 1.90E-03 & 8.90E-01 & 1.90E-02 & & 9.15E-01 \\
\hline $\mathrm{NI}$ & 3.70E-02 & $4.30 E+00$ & 5.30E-02 & & 4.37E+00 \\
\hline 1,1-DICHLOROETHENE & 2.00E-05 & 3.10E-04 & $6.80 \mathrm{E}-05$ & & 3.97E-04 \\
\hline CIS-1,2-DICHLOROETHENE & $6.40 \mathrm{E}-04$ & $1.20 \mathrm{E}-02$ & 2.50E-03 & & 1.53E-02 \\
\hline TETRACHLOROETHENE & 2.60E-05 & 1.70E-03 & $3.80 \mathrm{E}-03$ & & 5.51E-03 \\
\hline
\end{tabular}


Producel

\begin{tabular}{|c|c|c|c|c|c|}
\hline Land Use/Site/Contaminant & Ingestion & Fish & Dermal & Inhalation & Total HI \\
\hline Pathway Totals & 4.00E-02 & $5.20 \mathrm{E}+00$ & $8.20 E-02$ & & $5.31 \mathrm{E}+00$ \\
\hline \multicolumn{6}{|l|}{ Recreationnal; Seep SW5 1 , } \\
\hline$\overline{A S}$ & $1.00 \mathrm{E}-03$ & & $9.70 \mathrm{E}-04$ & & $2.00 \mathrm{E}-03$ \\
\hline$B E$ & 1.40E-05 & 1.60E-03 & 5.50E-04 & & 2.18E-03 \\
\hline FLUORIDE & 4.70E-04 & & 1.90E-04 & & $6.58 E-04$ \\
\hline $\mathrm{MN}$ & $1.00 E-02$ & $4.70 \mathrm{E}+00$ & 9.90E-02 & & $4.81 E+00$ \\
\hline V & $3.60 E-04$ & $4.20 \mathrm{E}-03$ & $1.40 E-02$ & & 1.85E-02 \\
\hline Pathway Totals & $1.20 \mathrm{E}-02$ & $4.70 \mathrm{E}+00$ & $1.10 \mathrm{E}-01$ & & $4.84 E+00$ \\
\hline \multicolumn{6}{|l|}{ Recreational;, Seep SW5-11 } \\
\hline$\overline{\mathrm{BE}}$ & $7.00 \mathrm{E}-06$ & $8.10 \mathrm{E}-04$ & $2.70 E-04$ & & $1.09 \mathrm{E}-03$ \\
\hline MN & $8.80 \mathrm{E}-04$ & 4.10E-01 & 8.50E-03 & & 4.15E-01 \\
\hline Pathway Totals & $8.90 \mathrm{E}-04$ & $4.10 \mathrm{E}-01$ & $8.80 \mathrm{E}-03$ & & 4.16E-01 \\
\hline \multicolumn{6}{|l|}{ Recreational; Seep SW5-2 $\therefore$} \\
\hline $\mathrm{BE}$ & 1.20E-05 & $1.40 \mathrm{E}-03$ & $4.80 \mathrm{E}-04$ & & 1.91E-03 \\
\hline V & $3.90 E-04$ & $4.50 E-03$ & $1.50 E-02$ & & 2.02E-02 \\
\hline 1,2-DICHLOROETHENE (TOTAL) & $1.80 E-03$ & 2.80E-03 & $9.10 E-04$ & & $5.44 \mathrm{E}-03$ \\
\hline CHLOROFORM & $1.80 \mathrm{E}-05$ & 4.00E-04 & $3.00 \mathrm{E}-04$ & & 7.17E-04 \\
\hline Pathway Totals & $2.20 E-03$ & $9.10 \mathrm{E}-03$ & $1.70 \mathrm{E}-02$ & & $2.83 \mathrm{E}-02$ \\
\hline \multicolumn{6}{|l|}{ Recréational, Seep SW5:3 } \\
\hline $\mathrm{BE}$ & $7.00 E-06$ & $8.10 \mathrm{E}-04$ & $2.70 \mathrm{E}-04$ & & 1.09E-03 \\
\hline FLUORIDE & $2.30 \mathrm{E}-02$ & & $9.40 E-03$ & & $3.29 E-02$ \\
\hline $\mathrm{MN}$ & 5.50E-04 & $2.50 E-01$ & 5.30E-03 & & 2.59E-01 \\
\hline CHLOROFORM & $1.80 E-05$ & 4.00E-04 & 3.00E-04 & & 7.17E-04 \\
\hline Pathway Totals & $2.40 \mathrm{E}-02$ & $2.50 \mathrm{E}-01$ & $1.50 E-02$ & & 2.94E-01 \\
\hline \multicolumn{6}{|l|}{ Recreational Seep SW5-4 } \\
\hline AS & $8.80 E-04$ & & $8.30 E-04$ & & 1.71E-03 \\
\hline$B E$ & 7.00E-06 & 8.10E-04 & 2.70E-04 & & $1.09 \mathrm{E}-03$ \\
\hline CD & $3.60 \mathrm{E}-04$ & $8.20 E-02$ & 1.40E-02 & & 9.64E-02 \\
\hline MN & $5.00 \mathrm{E}-03$ & $2.30 E+00$ & $4.80 \mathrm{E}-02$ & & $2.34 E+\dot{0} 0$ \\
\hline SB & 2.20E-03 & $2.50 \mathrm{E}-01$ & $4.30 \mathrm{E}-02$ & & 2.99E-01 \\
\hline Pathway Totals & $8.40 \mathrm{E}-03$ & $2.60 \mathrm{E}+00$ & $1.10 \mathrm{E}-01$ & & $2.74 \mathrm{E}+00$ \\
\hline Recreational, Seep SW5-5 & $x+2$ & $\therefore$ & & & \\
\hline$\overline{B E}$ & 8.50E-06 & $9.70 \mathrm{E}-04$ & 3.30E-04 & & 1.31E-03 \\
\hline MN & 8.50E-03 & $3.90 \mathrm{E}+00$ & $8.20 E-02$ & & $3.99 \mathrm{E}+00$ \\
\hline Pathway Totals & $8.50 \mathrm{E}-03$ & $3.90 \mathrm{E}+00$ & $8.30 E-02$ & & $4.00 \mathrm{E}+00$ \\
\hline \multicolumn{6}{|l|}{ Recreational; Seep SW5:6 } \\
\hline B & 5.10E-04 & & $2.20 E-04$ & & 7.31E-04 \\
\hline BE & 5.30E-06 & 6.10E-04 & 2.10E-04 & & 8.19E-04 \\
\hline MN & 1.50E-02 & 7.10E+00 & 1.50E-01 & & $7.23 E+00$ \\
\hline 1,2-DICHLOROET! & $3.20 \mathrm{E}-04$ & 5.10E-04 & 1.70E-04 & & 9.98E-04 \\
\hline Pathway Totals & $1.60 \mathrm{E}-02$ & $7.10 \mathrm{E}+00$ & $1.50 \mathrm{E}-01$ & & $7.24 \mathrm{E}+00$ \\
\hline \multicolumn{6}{|c|}{ Recreationals:Seep SW5-7 } \\
\hline$\overline{\mathrm{AS}}$ & $8.80 \mathrm{E}-04$ & & $8.30 \mathrm{E}-04$ & & 1.71E-03 \\
\hline B & 5.40E-04 & & 2.30E-04 & & 7.69E-04 \\
\hline BA & $3.50 E-04$ & $1.60 \mathrm{E}-03$ & 1.90E-03 & & 3.86E-03 \\
\hline & 5.30E-06 & $6.10 \mathrm{E}-04$ & 2.10E-04 & & 8.19E-04 \\
\hline
\end{tabular}


Produce/

\begin{tabular}{|c|c|c|c|c|c|}
\hline Land Use/Site/Contaminant & Ingestion & Fish & Dermal & Inhalation & Total HI \\
\hline $\mathrm{MN}$ & $1.70 \mathrm{E}-02$ & $7.70 \mathrm{E}+00$ & $1.60 \mathrm{E}-01$ & & $7.85 E+00$ \\
\hline Pathway Totals & 1.80E-02 & $7.70 \mathrm{E}+00$ & 1.60E-01 & & $7.86 E+00$ \\
\hline \multicolumn{6}{|l|}{ Recreational, Seep SW5-8 } \\
\hline $\bar{B}$ & $6.80 \mathrm{E}-04$ & & $2.90 E-04$ & & $9.79 E-04$ \\
\hline$B A$ & $3.50 \mathrm{E}-04$ & $1.60 \mathrm{E}-03$ & $1.90 \mathrm{E}-03$ & & $3.86 E-03$ \\
\hline MN & $9.30 \mathrm{E}-03$ & $4.30 E+00$ & $9.00 E-02$ & & $4.37 E+00$ \\
\hline Pathway Totals & $1.00 \mathrm{E}-02$ & $4.30 E+00$ & $9.20 \mathrm{E}-02$ & & $4.37 E+00$ \\
\hline \multicolumn{6}{|l|}{ Recreational, Seep SW5-9 } \\
\hline$\overline{A S}$ & $8.80 \mathrm{E}-04$ & & 8.30E-04 & & 1.71E-03 \\
\hline B & $9.20 \mathrm{E}-04$ & & 4.00E-04 & & 1.31E-03 \\
\hline$B A$ & $3.40 E-04$ & $1.60 E-03$ & $1.90 E-03$ & & $3.80 E-03$ \\
\hline$B E$ & 7.00E-06 & 8.10E-04 & 2.70E-04 & & $1.09 E-03$ \\
\hline MN & $9.50 E-03$ & $4.40 E+00$ & 9.20E-02 & & $4.47 E+00$ \\
\hline BENZENE, 1,2,4-TRICHLORO- & 2.10E-04 & 1.60E-01 & 8.50E-03 & & 1.66E-01 \\
\hline Pathway Totals & $1.20 \mathrm{E}-02$ & $4.50 E+00$ & $1.00 \mathrm{E}-01$ & & $4.64 E+00$ \\
\hline \multicolumn{6}{|l|}{ Recreational, Seep SW6-1 } \\
\hline$\overline{B E}$ & $3.50 \mathrm{E}-06$ & 4.10E-04 & 1.40E-04 & & $5.46 \mathrm{E}-04$ \\
\hline $\mathrm{MN}$ & $5.70 \mathrm{E}-03$ & $2.60 E+00$ & 5.50E-02 & & 2.67E+00 \\
\hline Pathway Totals & 5.70E-03 & $2.60 E+00$ & $5.50 \mathrm{E}-02$ & & $2.67 E+00$ \\
\hline \multicolumn{6}{|l|}{ Recreational, Seep SW6-2 } \\
\hline$\overline{A S}$ & $5.90 \mathrm{E}-04$ & & $5.60 \mathrm{E}-04$ & & $1.14 \mathrm{E}-03$ \\
\hline MN & 3.30E-03 & $1.50 E \div 00$ & 3.20E-02 & & 1.57E+00 \\
\hline SB & $1.30 \mathrm{E}-03$ & $1.50 \mathrm{E}-01$ & 2.60E-02 & & 1.79E-01 \\
\hline Pathway Totals & 5.20E-03 & $1.70 \mathrm{E}+00$ & 5.80E-02 & & $1.75 E+00$ \\
\hline \multicolumn{6}{|l|}{ Recreational, Seep SW7-1 } \\
\hline$\overline{B E}$ & $7.00 \mathrm{E}-06$ & $8.10 \mathrm{E}-04$ & $2.70 \mathrm{E}-04$ & & $1.09 \mathrm{E}-03$ \\
\hline MN & $1.20 E-02$ & $5.60 E+00$ & 1.20E-01 & & $5.69 E+00$ \\
\hline CARBON DISULFIDE & $3.60 \mathrm{E}-04$ & $1.20 \mathrm{E}-02$ & 5.30E-03 & & $1.72 E-02$ \\
\hline Pathway Totals & $1.20 \mathrm{E}-02$ & $5.60 \mathrm{E}+00$ & $1.20 \mathrm{E}-01$ & & $5.71 E+00$ \\
\hline \multicolumn{6}{|l|}{ Recreational, Seep SW7-2 } \\
\hline$\overline{B E}$ & $7.00 \mathrm{E}-06$ & $8.10 E-04$ & $2.70 E-04$ & & $1.09 E-03$ \\
\hline MN & $4.00 \mathrm{E}-04$ & $1.80 E-01$ & $3.90 E-03$ & & 1.89E-01 \\
\hline NITRATE & $1.50 \mathrm{E}-03$ & & $1.20 \mathrm{E}-03$ & & $2.64 \mathrm{E}-03$ \\
\hline Pathway Totals & $1.90 \mathrm{E}-03$ & $1.90 \mathrm{E}-01$ & $5.30 \mathrm{E}-03$ & & $1.92 \mathrm{E}-01$ \\
\hline \multicolumn{6}{|l|}{ Recreational, Seep SW7-3 } \\
\hline AS & 1.00E-03 & & $9.80 E-04$ & & $2.02 \mathrm{E}-03$ \\
\hline $\mathrm{BE}$ & 8.80E-06 & $1.00 E-03$ & $3.40 E-04$ & & 1.36E-03 \\
\hline$\overline{C R}$ & $1.20 E-03$ & 2.70E-01 & 2.30E-02 & & 2.93E-01 \\
\hline FLUORIDE & 5.10E-03 & & 2.10E-03 & & 7.19E-03 \\
\hline NITRATE & 1.10E-03 & & 8.50E-04 & & 1.95E-03 \\
\hline Pathway Totals & $8.50 \mathrm{E}-03$ & $2.70 \mathrm{E}-01$ & $2.70 \mathrm{E}-02$ & & $3.05 \mathrm{E}-01$ \\
\hline \multicolumn{6}{|l|}{ Recreational, Seep SW7-4 } \\
\hline $\mathrm{BE}$ & $8.80 E-06$ & $1.00 \mathrm{E}-03$ & $3.40 E-04$ & & 1.36E-03 \\
\hline MN & 1.40E-02 & $6.40 E+00$ & $1.40 E-01$ & & $6.58 \mathrm{E}+00$ \\
\hline NITRATE & 6.60E-04 & & 5.10E-04 & & 1.17E-03 \\
\hline$V$ & 3.10E-04 & $3.60 \mathrm{E}-03$ & 1.20E-02 & & $1.60 \mathrm{E}-02$ \\
\hline
\end{tabular}




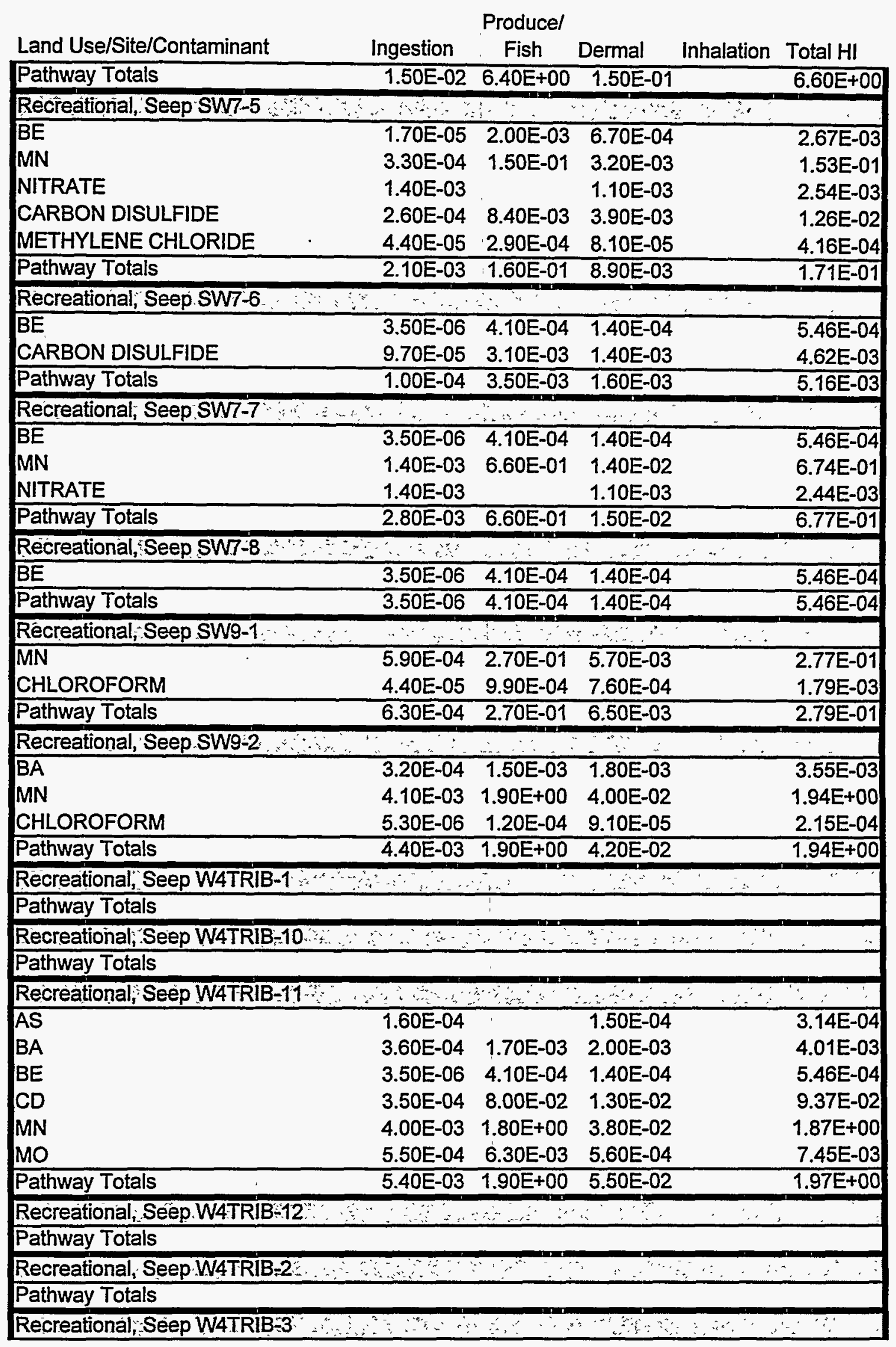


Produce/

\begin{tabular}{|c|c|c|c|c|c|}
\hline Land Use/Site/Contaminant & Ingestion & Fish & Dermal & Inhalation & Total HI \\
\hline \multicolumn{6}{|l|}{ Pathway Totals } \\
\hline \multicolumn{6}{|l|}{ Recreational, Seep W4TRIB-4 } \\
\hline \multicolumn{6}{|l|}{ Pathway Totals } \\
\hline \multicolumn{6}{|l|}{ Recreational, Seep W4TRIB-5 } \\
\hline$\overline{M N}$ & $3.40 \mathrm{E}-04$ & $1.60 \mathrm{E}-01$ & $3.30 \mathrm{E}-03$ & & 1.59E-01 \\
\hline Pathway Totals & $3.40 \mathrm{E}-04$ & $1.60 \mathrm{E}-01$ & $3.30 \mathrm{E}-03$ & & $1.59 \mathrm{E}-01$ \\
\hline \multicolumn{6}{|l|}{ Recreational, Seep W4TRIB-6 } \\
\hline \multicolumn{6}{|l|}{ Pathway Totals } \\
\hline \multicolumn{6}{|l|}{ Recreational, Seep W4TRIB-7 } \\
\hline$B$ & $4.00 E-04$ & & $1.70 \mathrm{E}-04$ & & 5.74E-04 \\
\hline MN & 7.00E-03 & $3.20 E+00$ & $6.80 \mathrm{E}-02$ & & $3.28 E+00$ \\
\hline Pathway Totals & $7.40 \mathrm{E}-03$ & $3.20 \mathrm{E}+00$ & $6.80 \mathrm{E}-02$ & & $3.28 E+00$ \\
\hline \multicolumn{6}{|l|}{ Recreational, Seep W4TRIB-8 } \\
\hline \multicolumn{6}{|l|}{ Pathway Totals } \\
\hline \multicolumn{6}{|l|}{ Recreational, Seep W4TRIB-9 } \\
\hline \multicolumn{6}{|l|}{ Pathway Totals } \\
\hline \multicolumn{6}{|l|}{ Recreational, Seep W6MS3 } \\
\hline \multicolumn{6}{|l|}{ Pathway Totals } \\
\hline \multicolumn{6}{|l|}{ Recreational, Seep WAG4 MS1 } \\
\hline $\mathrm{BE}$ & $1.40 \mathrm{E}-05$ & $1.60 \mathrm{E}-03$ & 5.30E-04 & & $2.12 E-03$ \\
\hline MN & 1.80E-03 & 8.30E-01 & $1.70 \mathrm{E}-02$ & & $8.45 E-01$ \\
\hline Pathway Totals & $1.80 \mathrm{E}-03$ & $8.30 \mathrm{E}-01$ & $1.80 \mathrm{E}-02$ & & 8.47E-01 \\
\hline \multicolumn{6}{|l|}{ Recreational, Seep WAG4 T2A } \\
\hline$\overline{B E}$ & $8.80 \mathrm{E}-06$ & $1.00 \mathrm{E}-03$ & $3.40 E-04$ & & 1.36E-03 \\
\hline FLUORIDE & $1.50 E-03$ & & $5.90 E-04$ & & 2.05E-03 \\
\hline$M N$ & $4.00 E-04$ & $1.80 \mathrm{E}-01$ & 3.90E-03 & & 1.87E-01 \\
\hline V & $3.00 \mathrm{E}-04$ & $3.40 \mathrm{E}-03$ & 1.10E-02 & & 1.51E-02 \\
\hline Pathway Totals & $2.20 \mathrm{E}-03$ & $1.90 \mathrm{E}-01$ & $1.60 \mathrm{E}-02$ & & 2.06E-01 \\
\hline \multicolumn{6}{|l|}{ Recreational, Seep WAG6 MS1 } \\
\hline$\overline{\mathrm{BE}}$ & $1.10 \mathrm{E}-05$ & $1.20 \mathrm{E}-03$ & $4.10 E-04$ & & $1.64 \mathrm{E}-03$ \\
\hline MN & $7.40 \mathrm{E}-03$ & $3.40 E+00$ & $7.20 \mathrm{E}-02$ & & $3.50 \mathrm{E}+00$ \\
\hline V & 3.40E-04 & 4.00E-03 & $1.30 \mathrm{E}-02$ & & 1.77E-02 \\
\hline CARBON DISULFIDE & 4.10E-04 & $1.30 \mathrm{E}-02$ & $6.00 \mathrm{E}-03$ & & $1.93 \mathrm{E}-02$ \\
\hline Pathway Totals & $8.20 E-03$ & $3.40 E+00$ & $9.20 \mathrm{E}-02$ & & $3.54 E+00$ \\
\hline \multicolumn{6}{|l|}{ Recreational, Seep WAG6 MS1-1 } \\
\hline AS & $1.20 \mathrm{E}-03$ & & $1.10 \mathrm{E}-03$ & & $2.29 \mathrm{E}-03$ \\
\hline MN & 2.30E-02 & $1.10 E+01$ & 2.20E-01 & & $1.09 E+01$ \\
\hline MO & 4.90E-04 & $5.70 \mathrm{E}-03$ & 5.00E-04 & & $6.68 E-03$ \\
\hline SB & 1.30E-03 & $1.50 \mathrm{E}-01$ & $2.60 E-02$ & & $1.79 E-01$ \\
\hline Pathway Totals & $2.60 \mathrm{E}-02$ & $1.10 \mathrm{E}+01$ & $2.50 \mathrm{E}-01$ & & $1.10 \mathrm{E}+01$ \\
\hline \multicolumn{6}{|l|}{ Recreational, Seep WAG6 MS2 } \\
\hline$\overline{B E}$ & $8.80 \mathrm{E}-06$ & $1.00 \mathrm{E}-03$ & $3.40 \mathrm{E}-04$ & & 1.36E-03 \\
\hline SB & 1.10E-03 & $1.30 \mathrm{E}-01$ & 2.10E-02 & & 1.49E-01 \\
\hline V & 2.90E-04 & 3.30E-03 & 1.10E-02 & & 1.47E-02 \\
\hline 1,1,2-TRICHLOROETHANE & 2.20E-05 & 4.90E-04 & 8.90E-05 & & 6.05E-04 \\
\hline CARBON TETRACHLORIDE & $1.30 \mathrm{E}-04$ & 1.10E-02 & $1.70 \mathrm{E}-03$ & & $1.32 E-02$ \\
\hline
\end{tabular}


Produce/

\begin{tabular}{|c|c|c|c|c|c|}
\hline Land Use/Site/Contaminant & Ingestion & Fish & Dermal & Inhalation & Total HI \\
\hline CHLOROFORM & 8.80E-06 & 2.00E-04 & $1.50 \mathrm{E}-04$ & & $3.59 E-04$ \\
\hline DIBROMOCHLOROMETHANE & 4.40E-06 & 1.40E-04 & $1.10 \mathrm{E}-05$ & & 1.56E-04 \\
\hline Pathway Totals & $1.60 \mathrm{E}-03$ & $1.40 \mathrm{E}-01$ & $3.50 \mathrm{E}-02$ & & $1.80 \mathrm{E}-01$ \\
\hline Recreational, Seep WAG6 MS3A & & & & & \\
\hline AS & $8.80 E-04$ & & $8.30 \mathrm{E}-04$ & & 1.71E-03 \\
\hline$B E$ & 8.80E-06 & $1.00 \mathrm{E}-03$ & 3.40E-04 & & 1.36E-03 \\
\hline FLUORIDE & 4.40E-04 & & 1.80E-04 & & 6.16E-04 \\
\hline MN & 1.10E-02 & $5.20 \mathrm{E}+00$ & 1.10E-01 & & $5.29 E+00$ \\
\hline Pathway Totals & 1.30E-02 & $5.20 E+00$ & $1.10 \mathrm{E}-01$ & & $5.29 E+00$ \\
\hline
\end{tabular}

Recreational, Seep WAG6 MS3A=1

Pathway Totals

Recreational, Seep.WAG6 MS3A-2

Pathway Totals

Recreational, Seep WAG6:MS3A-3

Pathway Totals

Recreational; :Seep WAG6:MS3B

\begin{tabular}{|lrrrr|}
\hline AS & $1.40 \mathrm{E}-03$ & & $1.30 \mathrm{E}-03$ & $2.68 \mathrm{E}-03$ \\
$\mathrm{BE}$ & $7.00 \mathrm{E}-06$ & $8.10 \mathrm{E}-04$ & $2.70 \mathrm{E}-04$ & $1.09 \mathrm{E}-03$ \\
$\mathrm{CR}$ & $5.90 \mathrm{E}-04$ & $1.40 \mathrm{E}-01$ & $1.10 \mathrm{E}-02$ & $1.48 \mathrm{E}-01$ \\
MN & $3.80 \mathrm{E}-03$ & $1.80 \mathrm{E}+00$ & $3.70 \mathrm{E}-02$ & $1.81 \mathrm{E}+00$ \\
\hline Pathway Totals & $5.80 \mathrm{E}-03$ & $1.90 \mathrm{E}+00$ & $5.00 \mathrm{E}-02$ & $1.96 \mathrm{E}+00$ \\
\hline
\end{tabular}

Recreational, Seep WAG6 MS3B-1:

Pathway Totals

Recreational; Seep WAG6. MS3B-2 :

Pathway Totals

Recreational, Seep.WAG6:MS3B $=3^{*}$

Pathway Totals

Recreational, Seep.WAG6 MS3B-4

Pathway Totals

Recreational; Seep WAG6 MS3B-5

Pathway Totals

Recreational;:Seep WAG6'MS3B=6

Pathway Totals

Recreational Seep WC-1

Pathway Totals

Recreational; Seep:WC-10

Pathway Totals

Recreational, Seep:WG-11:

Pathway Totals

Recreational Seep:WC-12

Pathway Totals

Recreational, Seep WC-13

Pathway Totals

Recreational,; Seep WC-14

Pathway Totals 
Producel

Land Use/Site/Contaminant

Ingestion

Fish

Dermal Inhalation Total HI

Recreational, Seep WC-15

Pathway Totals

Recreational, Seep WC-16

Pathway Totals

Recreational, Seep WC-17

Pathway Totals

Recreational, Seep.WC-18

Pathway Totals

Recreational, Seep WC-19

Pathway Totals

Recreational, Seep WC-2

Pathway Totals

Recreational, Seep WC-20

Pathway Totals

Recreational, Seep WC-22

Pathway Totals

Recreational, Seep WC-24

Pathway Totals

Recreational, Seep WC-3

Pathway Totals

Recreational, Seep WC-4

Pathway Totals

Recreational, Seep WC-5

Pathway Totals

Recreational, Seep WC-6

Pathway Totals

Recreational, Seep WC-7

Pathway Totals

Recreational, Seep WC-8

Pathway Totals

Recreational, Seep WC-9

Pathway Totals

Recreational, Seep WC7500

BE

FLUORIDE

8.80E-06

$1.00 \mathrm{E}-03$

3.40E-04

$5.90 \mathrm{E}-04$

1.36E-03

NITRATE

4.60E-04

3.50E-04

2.05E-03

CHLOROFORM

1.80E-05 4.00E-04 3.00E-04

8.11E-04

Pathway Totals

2.00E-03

$1.40 \mathrm{E}-03 \quad 1.60 \mathrm{E}-03$

7.17E-04

Recreational, Seep WCHEAD

BE

NITRATE

8.80E-06 1.00E-03 3.40E-04

4.30E-04 - 3.30E-04

4.95E-03

$\mathrm{V}$

3.20E-04 3.70E-03 1.30E-02

Pathway Totals

7.60E-04 4.80E-03 1.30E-02

1.36E-03

7.62E-04

Recreational, Seep WCTRIB"-1

BE

$\therefore$

8.80E-06 $1.00 \mathrm{E}-03 \quad 3.40 \mathrm{E}-04$

1.67E-02

$1.88 \mathrm{E}-02$ 


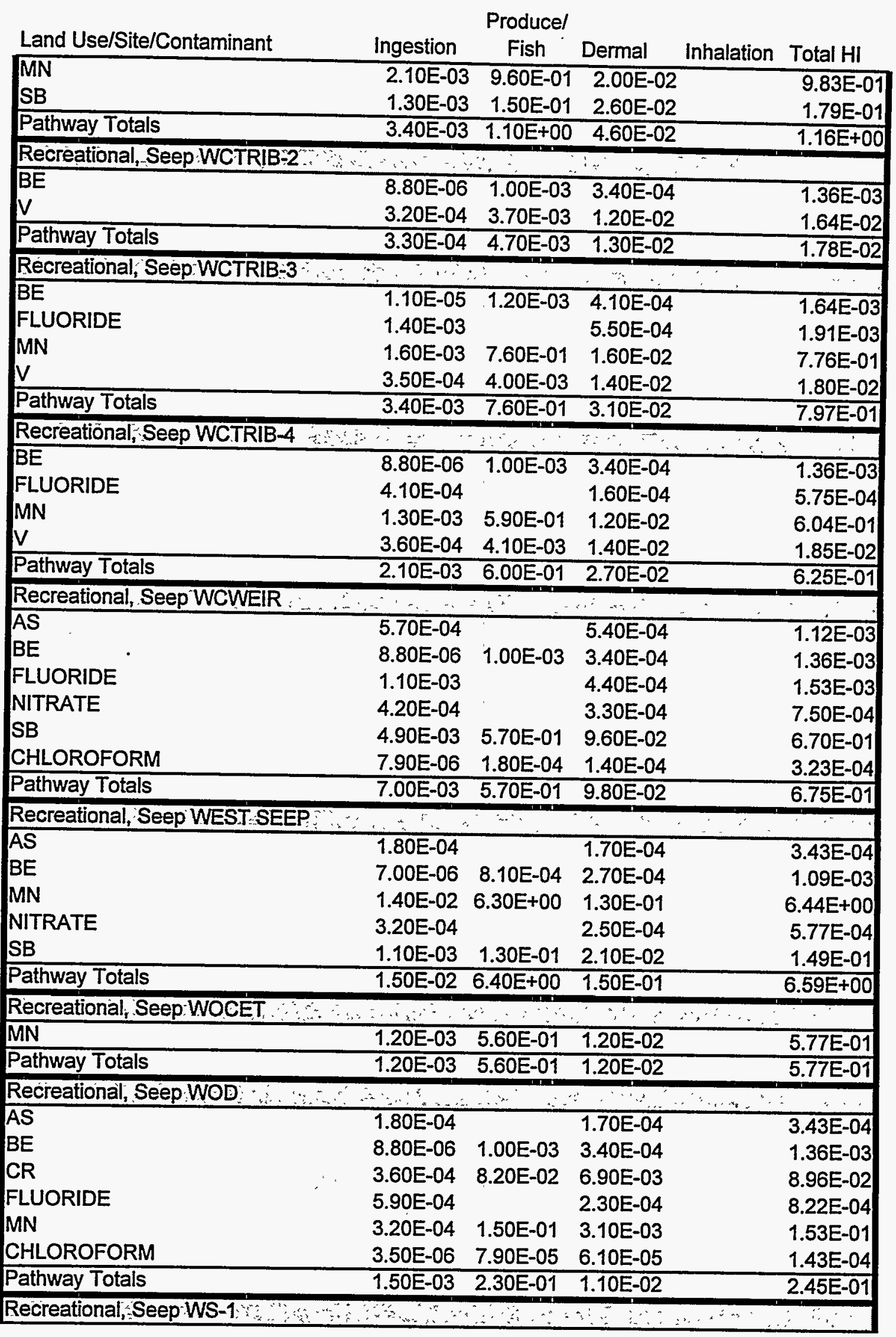




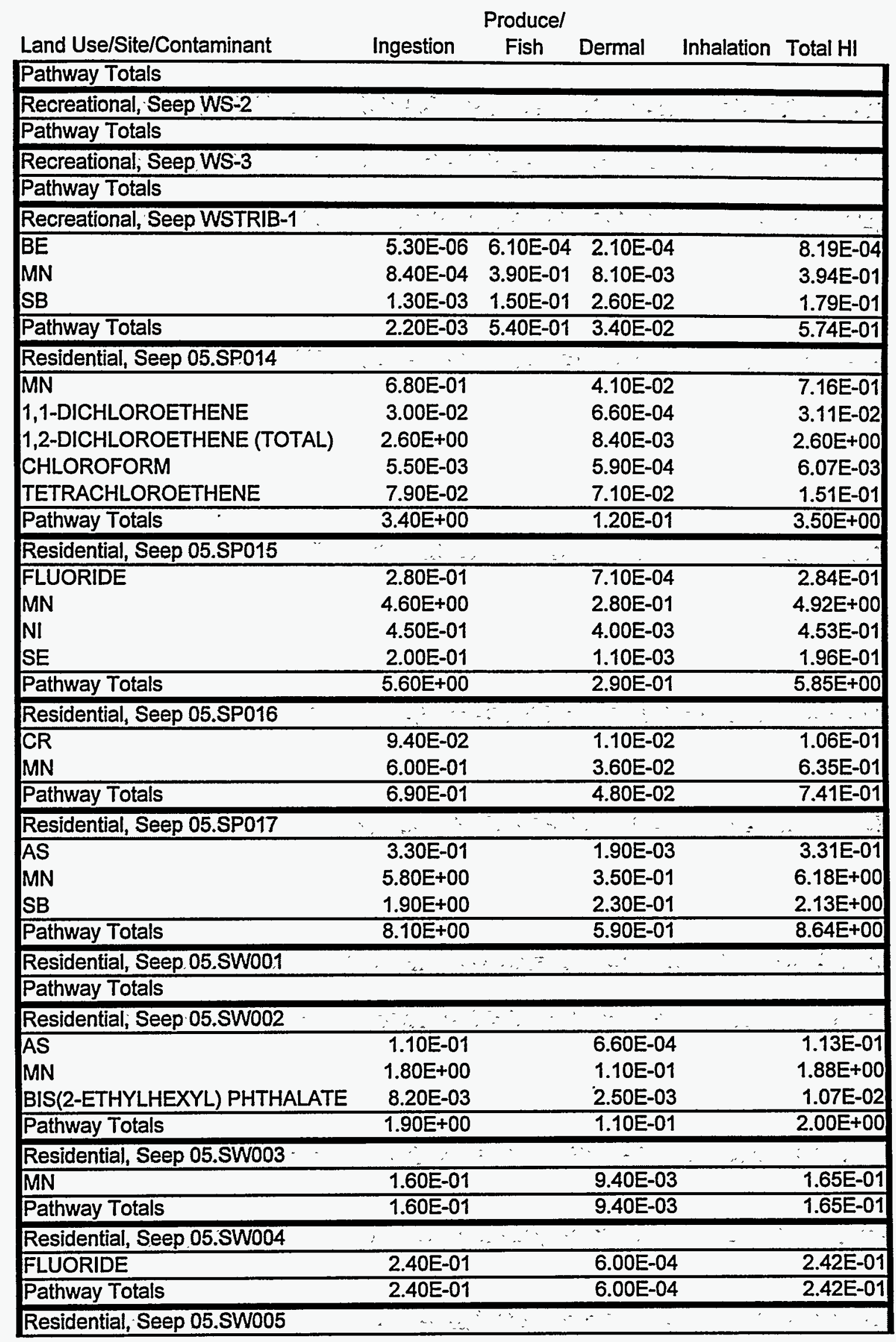




\begin{tabular}{|c|c|c|c|c|c|}
\hline Land Use/Site/Contaminant & Ingestion & $\begin{array}{c}\text { Produce } \\
\text { Fish }\end{array}$ & Dermal & Inhalation & Total HI \\
\hline FLUORIDE & $8.20 \mathrm{E}-01$ & & $2.10 \mathrm{E}-03$ & & $8.24 \mathrm{E}-01$ \\
\hline BIS(2-ETHYLHEXYL) PHTHALATE & 4.90E-02 & & 1.50E-02 & & $6.40 \mathrm{E}-02$ \\
\hline Pathway Totals & 8.70E-01 & & $1.70 \mathrm{E}-02$ & & $8.88 \mathrm{E}-01$ \\
\hline Residential; Seep 05.SW006 & & & & & \\
\hline FLUORIDE & 6.20 E-01 & & $1.50 \mathrm{E}-03$ & & $6.18 \mathrm{E}-01$ \\
\hline Pathway Totals & $6.20 E-01$ & & 1.50E-03 & & $6.18 \mathrm{E}-01$ \\
\hline Residential, Seep 5NNT: & & & $\therefore: \cdots$ & & \\
\hline $\mathrm{BE}$ & $2.20 \mathrm{E}-03$ & & 5.30E-04 & & $2.72 \mathrm{E}-03$ \\
\hline FLUORIDE & $1.80 \mathrm{E}-01$ & & 4.60E-04 & & 1.83E-01 \\
\hline V & $9.50 E-02$ & & 2.30E-02 & & 1.18E-01 \\
\hline CARBON DISULFIDE & 3.80E-02 & & 3.50E-03 & $9.60 E-02$ & 1.38E-01 \\
\hline METHYLENE CHLORIDE & $5.90 \mathrm{E}-03$ & & $6.80 \mathrm{E}-05$ & 2.10E-03 & 8.08E-03 \\
\hline Pathway Totals & $3.20 \mathrm{E}-01$ & & 2.80E-02 & $9.80 \mathrm{E}-02$ & 4.49E-01 \\
\hline Residential; Seep 5NST: & $\because$ & & $\because:$ & & \\
\hline$\overline{B E}$ & $3.30 \mathrm{E}-03$ & & $8.00 E-04$ & & $4.08 \mathrm{E}-03$ \\
\hline MN & $9.70 E-02$ & & 5.90E-03 & & 1.03E-01 \\
\hline V & $1.30 \mathrm{E}-01$ & & 3.10E-02 & & 1.57E-01 \\
\hline Pathway Totals & $2.30 \mathrm{E}-01$ & & $3.70 \mathrm{E}-02$ & & $2.63 E-01$ \\
\hline Residential, Seep 5NW-1, & $\therefore \therefore \cdots$ & & $\therefore \therefore$ & & \\
\hline$\overline{\mathrm{BE}}$ & 2.70E-03 & & 6.60E-04 & & $3.40 E-03$ \\
\hline MN & 5.40E-01 & & 3.30E-02 & & 5.74E-01 \\
\hline V & 1.10E-01 & & 2.60E-02 & & 1.32E-01 \\
\hline Pathway Totals & 6.50E-01 & & 5.90E-02 & & $7.09 E-01$ \\
\hline Residential, Seep.5NW-2 & $\therefore$ & & & & \\
\hline$\overline{\mathrm{BE}}$ & $2.70 \mathrm{E}-03$ & & $6.60 \mathrm{E}-04$ & & $3.40 \mathrm{E}-03$ \\
\hline MN & $3.10 E+00$ & & 1.90E-01 & & $3.32 E+00$ \\
\hline V & $9.90 \mathrm{E}-02$ & & 2.40E-02 & & 1.23E-01 \\
\hline Pathway Totals & $3.20 E+00$ & & $2.10 \mathrm{E}-01$ & & $3.45 E+00$ \\
\hline Residential, Seep BTT & 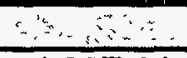 & & $\because$ & $\because$. & $\therefore$ \\
\hline$\overline{B A}$ & $1.20 \mathrm{E}-01$ & & $4.20 \mathrm{E}-03$ & & $1.26 E-01$ \\
\hline BE & 3.30E-03 & & 8.10E-04 & & 4.14E-03 \\
\hline FLUORIDE & $1.20 \mathrm{E}-01$ & & 3.00E-04 & & 1.19E-01 \\
\hline MO & 5.60E-01 & & $3.50 E-03$ & & 5.59E-01 \\
\hline Pathway Totals & $8.00 \mathrm{E}-01$ & & 8.90E-03 & & $8.08 E-01$ \\
\hline Residential, Seep.EAST SEEP & & & $\ldots$ & $\therefore$ & $\because$ \\
\hline$\overline{A S}$ & $3.20 \mathrm{E}-01$ & & 1.90E-03 & & $\overline{3.19 E-01}$ \\
\hline$B E$ & 2.70E-03 & & 6.60E-04 & & $3.40 \mathrm{E}-03$ \\
\hline CR & 1.40E-01 & & 1.70E-02 & & $1.59 \mathrm{E}-01$ \\
\hline FLUORIDE & 5.50E-01 & & $1.40 E-03$ & & 5.49E-01 \\
\hline MN & 2.30E-01 & & $1.40 \mathrm{E}-02$ & & 2.42E-01 \\
\hline NITRATE & 3.30E-01 & & $1.60 \mathrm{E}-03$ & & 3.27E-01 \\
\hline Pathway Totals & $1.60 \mathrm{E}+00$ & & $3.60 \mathrm{E}-02$ & & $1.60 \mathrm{E}+00$ \\
\hline Residential, Seep:FC-1 & $\because x$ & & $\therefore$ & & \\
\hline Pathway Totals & & & & & \\
\hline Sidential, Seep FIFTH CREEK" & $\because>+>$ & & & & \\
\hline
\end{tabular}




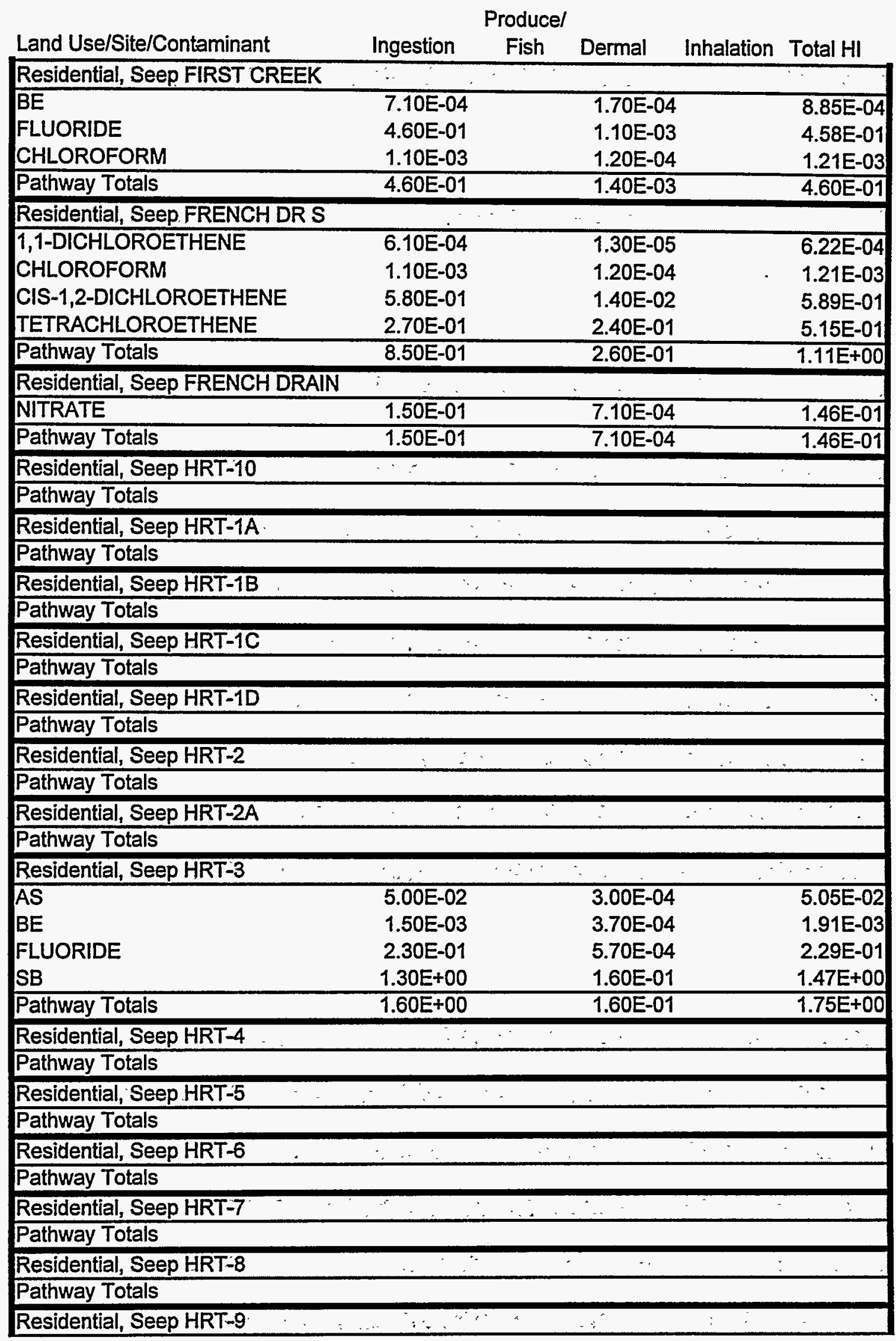




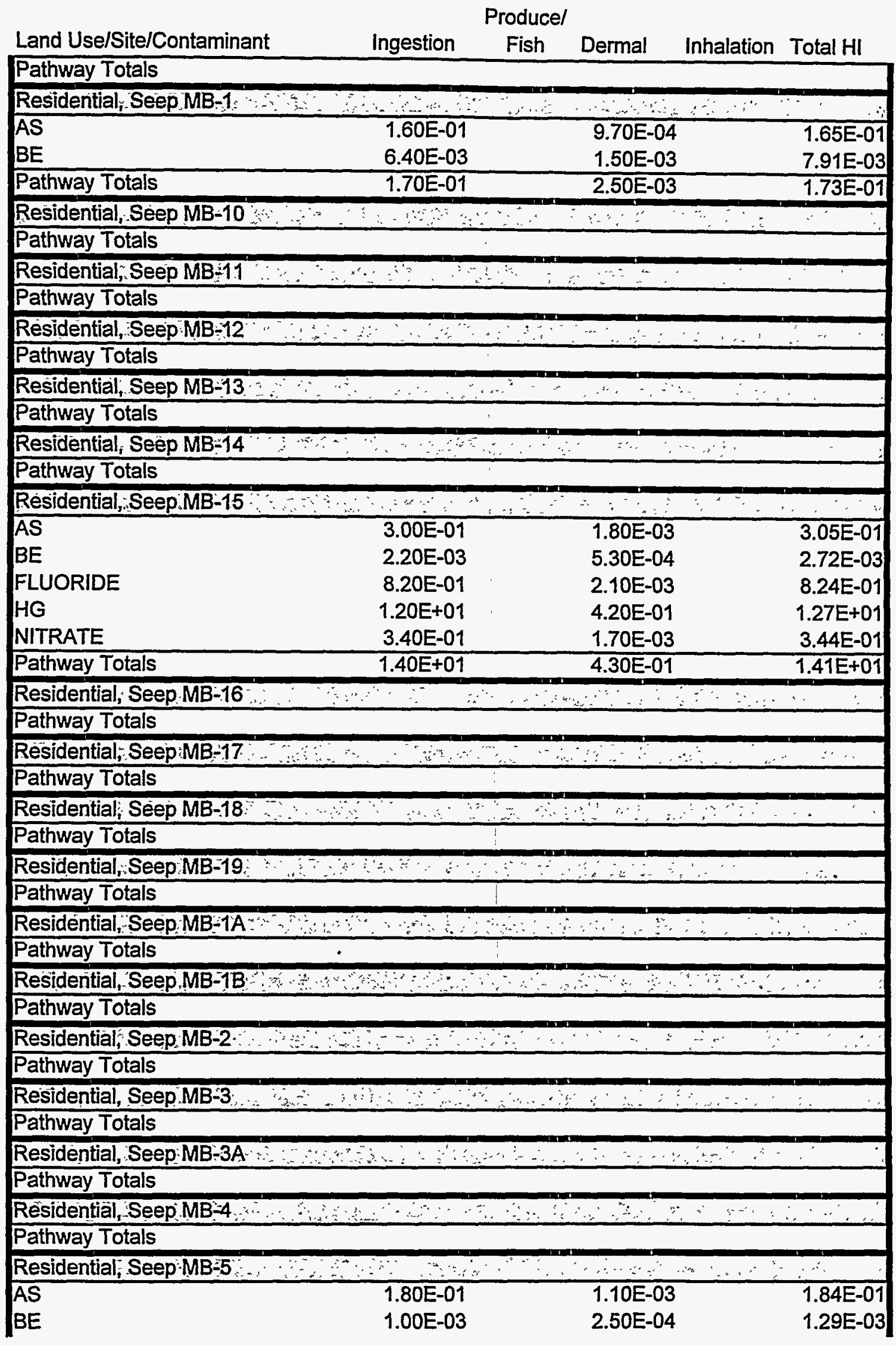




\begin{tabular}{|c|c|c|c|c|c|}
\hline & & roduce & & & \\
\hline Land Use/Site/Contaminant & Ingestion & Fish & Dermal & Inhalation & Total HI \\
\hline Pathway Totals & 1.80E-01 & & $1.30 \mathrm{E}-03$ & & 1.85E-01 \\
\hline Residential, Seep MB-6 & & & & & \\
\hline Pathway Totals & & & & & \\
\hline Residential, Seep MB-7. & & & & & \\
\hline Pathway Totals & & & & & \\
\hline Residential, Seep MB-7A SIDE & & & & & \\
\hline Pathway Totals & & & & & \\
\hline Residential, Seep MB-7B & & & & & \\
\hline Pathway Totals & & & & & \\
\hline Residential, Seep MB-8 & & & & & \\
\hline Pathway Totals & & & & & \\
\hline Residential, Seep MB-9 & & & & & \\
\hline Pathway Totals & & & & & \\
\hline Residential, Seep MBTRIB-1 & & & & & \\
\hline Pathway Totals & & & & & \\
\hline Residential, Seep MBTRIB-2A & & & & & \\
\hline Pathway Totals & & & & & \\
\hline Residential, Seep MBTRIB-2B & & & & & \\
\hline Pathway Totals & & & & & \\
\hline Residential, Seep MBTRIB-3 & & & & & \\
\hline MN & 3.00E-01 & & $1.80 \mathrm{E}-02$ & & 3.14E-01 \\
\hline CHLOROFORM & $1.60 \mathrm{E}-02$ & & 1.80E-03 & & 1.82E-02 \\
\hline Pathway Totals & 3.10E-01 & & $2.00 E-02$ & & $3.33 E-01$ \\
\hline Residential, Seep MBWEIR & & & & & \\
\hline AS & 2.10E-01 & & $1.20 E-03$ & & 2.07E-01 \\
\hline$B E$ & 2.70E-03 & & 6.60E-04 & & $3.40 E-03$ \\
\hline FLUORIDE & 5.90E-01 & & 1.50E-03 & & 5.90E-01 \\
\hline MN & $1.00 \mathrm{E}-01$ & & 6.30E-03 & & 1.11E-01 \\
\hline NITRATE & 3.10E-01 & & $1.50 E-03$ & & 3.08E-01 \\
\hline SB & $1.30 \mathrm{E}+00$ & & 1.60E-01 & & $1.47 E+00$ \\
\hline Pathway Totals & $2.50 E+00$ & & 1.70E-01 & & $2.69 E+00$ \\
\hline Residential, Seep MID..DRAIN. & $\therefore$ & & & & \\
\hline AS & 7.30E-02 & & 4.30E-04 & & 7.35E-02 \\
\hline BE & 1.60E-03 & & 4.00E-04 & & 2.04E-03 \\
\hline MN & $1.90 \mathrm{E}+00$ & & 1.20E-01 & & $2.03 E+00$ \\
\hline Pathway Totals & $2.00 E+00$ & & 1.20E-01 & & 2.11E+00 \\
\hline Residential, Seep MV-1 & 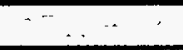 & $=$ & & & \\
\hline AS & $2.10 \mathrm{E}-01$ & & $1.20 \mathrm{E}-03$ & & 2.11E-01 \\
\hline MN & 2.30E+00 & & $1.40 \mathrm{E}-01$ & & $2.48 E+00$ \\
\hline Pathway Totals & $2.60 E+00$ & & $1.40 \mathrm{E}-01$ & & $2.70 E+00$ \\
\hline Residential, Seep MV-3 & & & & & \\
\hline Pathway Totals & & & & & \\
\hline Residential, Seep NON RAD OU & $=$ & & & & \\
\hline Pathway Totals & & & & & \\
\hline esidential, Seep NWTRIB & & & & & \\
\hline
\end{tabular}




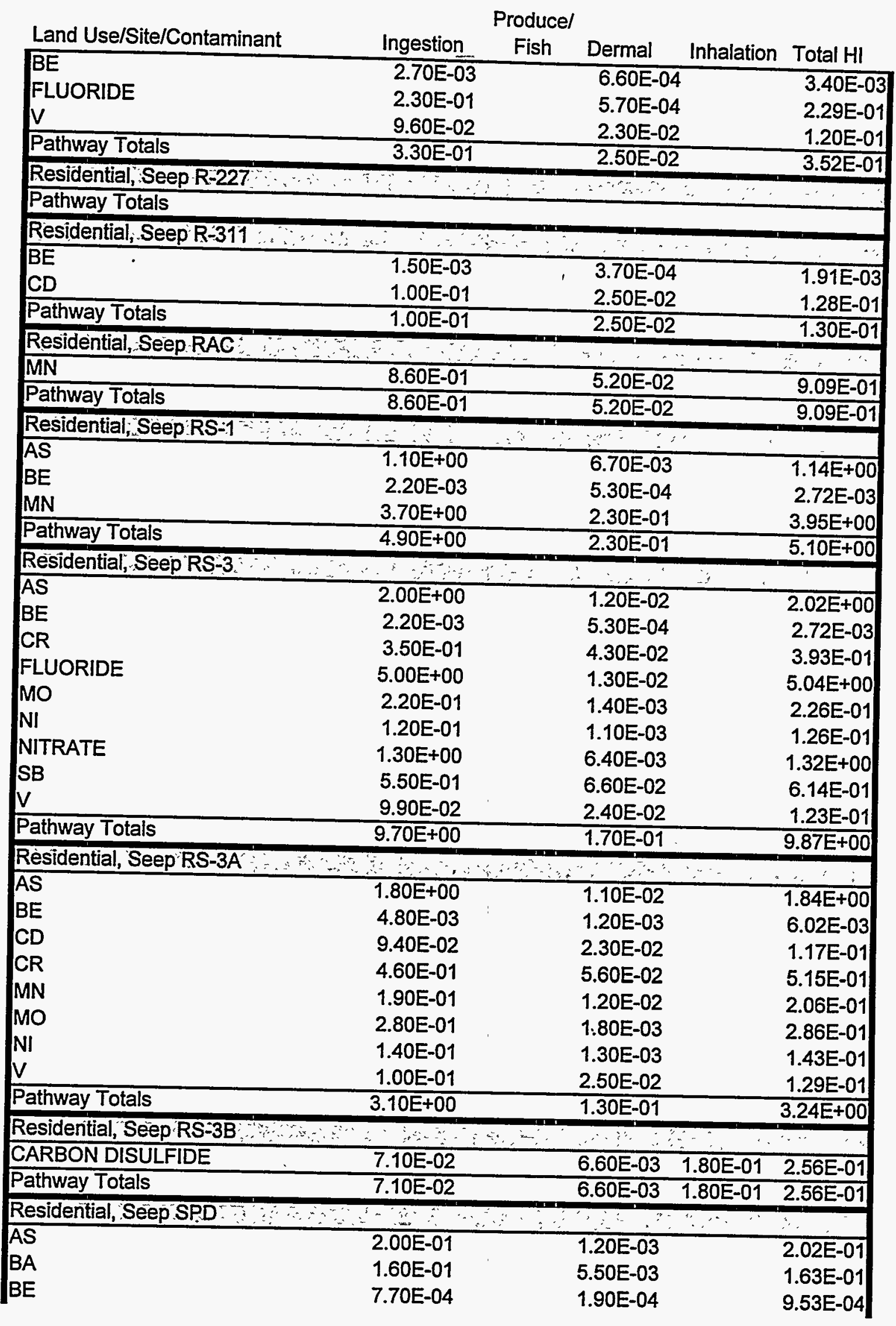


Producel

\begin{tabular}{|c|c|c|c|c|c|}
\hline Land Use/Site/Contaminant & Ingestion & Fish & Dermal & Inhalation & Total HI \\
\hline$\overline{\mathrm{MN}}$ & $2.90 \mathrm{E}+00$ & & $1.70 \mathrm{E}-01$ & & $3.03 E+00$ \\
\hline Pathway Totals & $3.20 \mathrm{E}+00$ & & $1.80 \mathrm{E}-01$ & & $3.39 E+00$ \\
\hline \multicolumn{6}{|l|}{ Residential, Seep SW2-1 } \\
\hline$\overline{\mathrm{BE}}$ & $2.20 \mathrm{E}-03$ & & $5.30 E-04$ & & $2.72 E-03$ \\
\hline MN & $1.20 E+00$ & & 7.20E-02 & & $1.25 \mathrm{E}+00$ \\
\hline CARBON DISULFIDE & $3.30 \mathrm{E}-02$ & & $3.00 \mathrm{E}-03$ & 8.20E-02 & $1.18 \mathrm{E}-01$ \\
\hline Pathway Totals & $1.20 E+00$ & & $7.50 \mathrm{E}-02$ & $8.20 E-02$ & $1.37 \mathrm{E}+00$ \\
\hline \multicolumn{6}{|l|}{ Residential, Seep SW2-2 } \\
\hline $\mathrm{BE}$ & 3.30E-03 & & $8.00 E-04$ & & $4.08 \mathrm{E}-03$ \\
\hline FLUORIDE & 1.30 E-01 & & $3.20 E-04$ & & $1.28 E-01$ \\
\hline MN & $5.80 E-01$ & & $3.50 \mathrm{E}-02$ & & $6.14 E-01$ \\
\hline V & $1.20 \mathrm{E}-01$ & & $2.90 \mathrm{E}-02$ & & 1.47E-01 \\
\hline Pathway Totals & $8.30 \mathrm{E}-01$ & & 6.50E-02 & & 8.93E-01 \\
\hline \multicolumn{6}{|l|}{ Residential, Seep SW2-3 } \\
\hline$\overline{B E}$ & $2.70 \mathrm{E}-03$ & & $6.60 \mathrm{E}-04$ & & $3.40 \mathrm{E}-03$ \\
\hline V & $9.80 \mathrm{E}-02$ & & $2.40 E-02$ & & $1.22 E-01$ \\
\hline Pathway Totals & $1.00 \mathrm{E}-01$ & & $2.40 \mathrm{E}-02$ & & 1.25E-01 \\
\hline \multicolumn{6}{|l|}{ Residential, Seep SW2-4 } \\
\hline$\overline{A S}$ & $2.70 \mathrm{E}-01$ & & $1.60 E-03$ & & $2.76 E-01$ \\
\hline $\mathrm{MN}$ & $6.20 E+00$ & & $3.80 E-01$ & & $6.60 E+00$ \\
\hline Pathway Totals & $6.50 \mathrm{E}+00$ & & $3.80 \mathrm{E}-01$ & & $6.88 \mathrm{E}+00$ \\
\hline \multicolumn{6}{|l|}{ Residential, Seep SW2-5 } \\
\hline $\mathrm{BA}$ & 1.20E-01 & & 4.10E-03. & & 1.24E-01 \\
\hline BE & $9.30 \mathrm{E}-04$ & & $2.30 \mathrm{E}-04$ & & 1.16E-03 \\
\hline MN & 7.30E-01 & & 4.40E-02 & & 7.74E-01 \\
\hline CARBON DISULFIDE & $6.60 \mathrm{E}-02$ & & $6.10 \mathrm{E}-03$ & $1.60 \mathrm{E}-01$ & 2.36E-01 \\
\hline Pathway Totals & $9.20 \mathrm{E}-01$ & & 5.50E-02 & 1.60E-01 & $1.14 E+00$ \\
\hline \multicolumn{6}{|l|}{ Residential, Seep SW2-6 } \\
\hline$\overline{\mathrm{AS}}$ & $9.10 \mathrm{E}-02$ & & $5.40 E-04$ & & $9.19 E-02$ \\
\hline $\mathrm{BE}$ & $9.30 \mathrm{E}-04$ & & 2.30E-04 & & 1.16E-03 \\
\hline MN & 8.00E-01 & & 4.80E-02 & & 8.47E-01 \\
\hline Pathway Totals & $8.90 \mathrm{E}-01$ & & $4.90 \mathrm{E}-02$ & & $9.40 \mathrm{E}-01$ \\
\hline \multicolumn{6}{|l|}{ Residential, Seep SW2-7 } \\
\hline AS & $1.30 \mathrm{E}-01$ & & $7.60 \mathrm{E}-04$ & & $1.29 E-01$ \\
\hline $\mathrm{BE}$ & $1.60 \mathrm{E}-03$ & & 3.90E-04 & & 1.97E-03 \\
\hline MN & $1.10 \mathrm{E}+00$ & & $6.80 \mathrm{E}-02$ & & $1.18 \mathrm{E}+00$ \\
\hline Pathway Totals & $1.20 E+00$ & & $6.90 \mathrm{E}-02$ & & $1.31 E+00$ \\
\hline \multicolumn{6}{|l|}{ Residential, Seep.SW4-1 } \\
\hline$\overline{A S}$ & $5.70 \mathrm{E}-01$ & & 3.30E-03 & & $5.70 \mathrm{E}-01$ \\
\hline$B A$ & 2.10E-01 & & 7.20E-03 & & 2.16E-01 \\
\hline$B E$ & $4.40 E-03$ & & 1.10E-03 & & $5.45 \mathrm{E}-03$ \\
\hline FLUORIDE & $7.20 E+00$ & & $1.80 \mathrm{E}-02$ & & $7.19 E+00$ \\
\hline MN & $2.20 \mathrm{E}+00$ & & 1.30E-01 & & $2.30 E+00$ \\
\hline SB & $2.90 \mathrm{E}+00$ & & $3.60 E-01$ & & $3.28 E+00$ \\
\hline V & $8.80 E-02$ & & 2.10E-02 & & 1.10E-01 \\
\hline 1,1-DICHLOROETHENE & $1.50 E-03$ & & 3.30E-05 & & $1.55 E-03$ \\
\hline
\end{tabular}




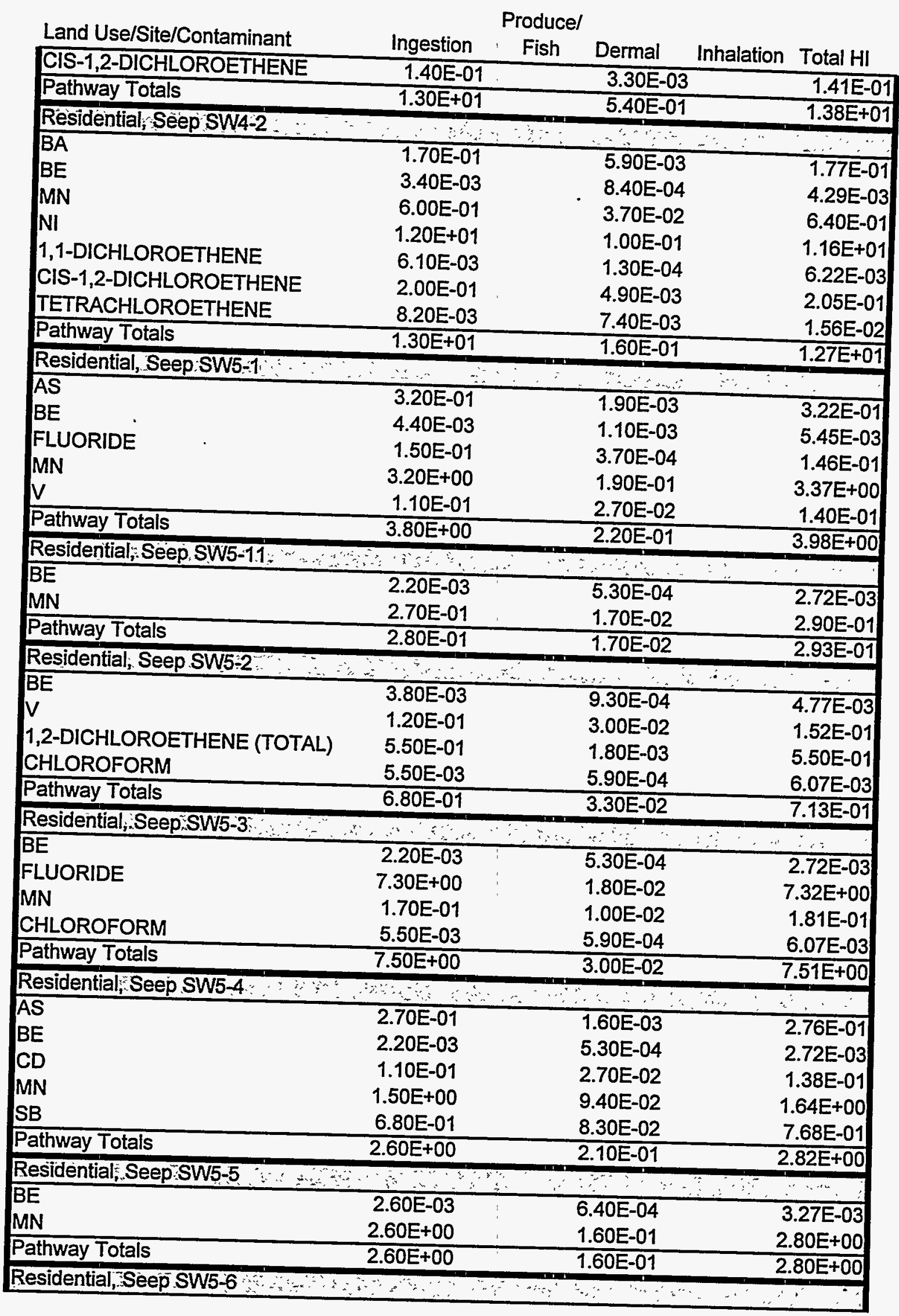




\begin{tabular}{|c|c|c|c|c|c|}
\hline & & du & & & \\
\hline Land Use/Site/Contaminant & Ingestion & Fish & Dermal & Inhalation & Total HI \\
\hline $\bar{B}$ & $1.60 E-01$ & & 4.30E-04 & & 1.59E-01 \\
\hline $\mathrm{BE}$ & 1.60E-03 & & $4.00 E-04$ & & 2.04E-03 \\
\hline $\mathrm{MN}$ & $4.80 \mathrm{E}+00$ & & 2.90E-01 & & $5.06 E+00$ \\
\hline 1,2-DICHLOROETHENE (TOTAL) & 1.00E-01 & & $3.30 E-04$ & & 1.01E-01 \\
\hline 1,2-DICHLOROPROPANE & & & & 1.20E-01 & $1.20 \mathrm{E}-01$ \\
\hline Pathway Totals & $5.00 E+00$ & & 2.90E-01 & $1.20 E-01$ & $5.44 \mathrm{E}+00$ \\
\hline Residential, Seep SW5-7 & & & & & \\
\hline AS & $2.70 \mathrm{E}-01$ & & 1.60E-03 & & 2.76E-01 \\
\hline B & 1.70E-01 & & $4.50 E-04$ & & $1.68 E-01$ \\
\hline BA & 1.10E-01 & & 3.70E-03 & & 1.11E-01 \\
\hline BE & 1.60E-03 & & $4.00 E-04$ & & 2.04E-03 \\
\hline MN & $5.20 \mathrm{E}+00$ & & $3.10 \mathrm{E}-01$ & & $5.50 E+00$ \\
\hline Pathway Totals & $5.70 \mathrm{E}+00$ & & $3.20 E-01$ & & $6.05 \mathrm{E}+00$ \\
\hline Residential, Seep SW5-8 & & & . & & \\
\hline $\bar{B}$ & $2.10 E-01$ & & $5.70 \mathrm{E}-04$ & & $2.13 E-01$ \\
\hline BA & 1.10E-01 & & 3.70E-03 & & 1.11E-01 \\
\hline MN & $2.90 E+00$ & & $1.70 E-01$ & & $3.06 E+00$ \\
\hline DICHLOROBENZENE,1,4- & & & & $4.20 E-03$ & 4.20E-03 \\
\hline Pathway Totals & $3.20 E+00$ & & 1.80E-01 & $4.20 E-03$ & $3.39 E+00$ \\
\hline Residential, Seep SW5-9 & & & & & \\
\hline AS & 2.70E-01 & & $1.60 \mathrm{E}-03$ & & $2.76 E-01$ \\
\hline B & 2.90E-01 & & 7.70E-04 & & 2.86E-01 \\
\hline BA & $1.10 E-01$ & & $3.70 E-03$ & & 1.10E-01 \\
\hline BE & 2.20E-03 & & 5.30E-04 & & 2.72E-03 \\
\hline MN & $2.90 E+00$ & & $1.80 E-01$ & & $3.13 E+00$ \\
\hline BENZENE, 1,2,4-TRICHLORO- & $6.60 E-02$ & & 1.60E-02 & 5.80E-02 & 1.40E-01 \\
\hline DICHLOROBENZENE,1,4- & & & & 4.20E-03 & 4.20E-03 \\
\hline Pathway Totals & $3.70 \mathrm{E}+00$ & & $2.00 \mathrm{E}-01$ & $6.20 \mathrm{E}-02$ & $3.94 \mathrm{E}+00$ \\
\hline Residential, Seep SW6-1 & & & & & \\
\hline$\overline{\mathrm{BE}}$ & $1.10 \mathrm{E}-03$ & & $2.70 E-04$ & & $1.36 \mathrm{E}-03$ \\
\hline MN & $1.80 \mathrm{E}+00$ & & 1.10E-01 & & 1.87E+00 \\
\hline Pathway Totals & $1.80 \mathrm{E}+00$ & & $1.10 E-01$ & & $1.87 E+00$ \\
\hline Residential, Seep SW6-2 & & & & & \\
\hline$\overline{A S}$ & 1.80E-01 & & 1.10E-03 & & $1.84 \mathrm{E}-01$ \\
\hline$M N$ & 1.00E+00 & & 6.30E-02 & & 1.10E+00 \\
\hline$S B$ & 4.10E-01 & & 5.00E-02 & & 4.61E-01 \\
\hline Pathway Totals & $1.60 \mathrm{E}+00$ & & 1.10E-01 & & $1.74 E+00$ \\
\hline Residential,.Seep SW7-1 & & & & & \\
\hline $\mathrm{BE}$ & $2.20 \mathrm{E}-03$ & & 5.30E-04 & & 2.72E-03 \\
\hline MN & $3.80 \mathrm{E}+00$ & & 2.30E-01 & & $3.99 E+00$ \\
\hline CARBON DISULFIDE & 1.10E-01 & & $1.00 \mathrm{E}-02$ & 2.80E-01 & 4.04E-01 \\
\hline Pathway Totals & $3.90 \mathrm{E}+00$ & & $2.40 \mathrm{E}-01$ & $2.80 \mathrm{E}-01$ & $4.39 \mathrm{E}+00$ \\
\hline Residential, Seep SW7:-2 & & & & & \\
\hline$\overline{\mathrm{BE}}$ & 2.20E-03 & & 5.30E-04 & & $2.72 E-03$ \\
\hline MN & 1.20E-01 & & $7.50 E-03$ & & 1.32E-01 \\
\hline NITRATE & $4.60 \mathrm{E}-01$ & & 2.20E-03 & & 4.65E-01 \\
\hline
\end{tabular}




\begin{tabular}{|c|c|c|c|c|c|}
\hline Land Use/Site/Contaminant & Ingestion & $\begin{array}{l}\text { roduce/ } \\
\text { Fish }\end{array}$ & Dermal & Inhalation & Total HI \\
\hline Pathway Totals & 5.90E-01 & & $1.00 \mathrm{E}-02$ & & 5.99E-01 \\
\hline \multicolumn{6}{|l|}{ Rêsidential, Seep SW7-3: : : } \\
\hline AS & $3.20 \mathrm{E}-01$ & & 1.90E-03 & & $3.25 E-01$ \\
\hline$B E$ & 2.70E-03 & & $6.60 \mathrm{E}-04$ & & $3.40 E-03$ \\
\hline CR & 3.60E-01 & & 4.40E-02 & & 4.07E-01 \\
\hline FLUORIDE & $1.60 \mathrm{E}+00$ & & 4.00E-03 & & $1.60 E+00$ \\
\hline NITRATE & 3.40E-01 & & $1.70 E-03$ & & 3.44E-01 \\
\hline Pathway Totals & $2.60 \mathrm{E}+00$ & & $5.20 \mathrm{E}-02$ & & $2.68 E+00$ \\
\hline \multicolumn{6}{|l|}{ Residential, Seep SW7-4: } \\
\hline$\overline{B E}$ & $2.70 \mathrm{E}-03$ & & $6.60 \mathrm{E}-04$ & & $3.40 \mathrm{E}-03$ \\
\hline MN & $4.30 \mathrm{E}+00$ & & 2.60E-01 & & 4.61E+00 \\
\hline NITRATE & 2.10E-01 & & $1.00 \mathrm{E}-03$ & & 2.06E-01 \\
\hline V & $9.70 \mathrm{E}-02$ & & $2.40 \mathrm{E}-02$ & & 1.21E-01 \\
\hline Pathway Totals & $4.60 \mathrm{E}+00$ & & $2.90 \mathrm{E}-01$ & & $4.94 E+00$ \\
\hline \multicolumn{6}{|l|}{ Rêsidential, Seep SW7:5 } \\
\hline$\overline{\mathrm{BE}}$ & $5.40 \mathrm{E}-03$ & & $1.30 \mathrm{E}-03$ & & $6.67 \mathrm{E}-03$ \\
\hline MN & 1.00E-01 & & $6.10 \mathrm{E}-03$ & & 1.07E-01 \\
\hline NITRATE & 4.50E-01 & & 2.20E-03 & & 4.47E-01 \\
\hline CARBON DISULFIDE & $8.20 E-02$ & & 7.60E-03 & 2.10E-01 & 2.95E-01 \\
\hline METHYLENE CHLORIDE & $1.40 \mathrm{E}-02$ & & $1.60 \mathrm{E}-04$ & 4.80E-03 & 1.87E-02 \\
\hline Pathway Totals & $6.50 \mathrm{E}-01$ & & 1.70E-02 & $2.10 \mathrm{E}-01$ & 8.75E-01 \\
\hline \multicolumn{6}{|l|}{ Residèntial ${ }_{\text {, Seép SW7-6 }}$} \\
\hline $\mathrm{BE}$ & $1.10 \mathrm{E}-03$ & & $2.70 \mathrm{E}-04$ & & $1.36 \mathrm{E}-03$ \\
\hline CARBON DISULFIDE & 3.00E-02 & & $2.80 \mathrm{E}-03$ & 7.50E-02 & 1.08E-01 \\
\hline Pathway Totals & $3.10 \mathrm{E}-02$ & & $3.00 \mathrm{E}-03$ & $7.50 \mathrm{E}-02$ & 1.10E-01 \\
\hline \multicolumn{6}{|c|}{ Residential, Seep SW7:7 } \\
\hline $\mathrm{BE}$ & 1.10E-03 & & 2.70E-04 & & $1.36 \mathrm{E}-03$ \\
\hline MN & $4.40 \mathrm{E}-01$ & & 2.70E-02 & & 4.71E-01 \\
\hline NITRATE & 4.30E-01 & & 2.10E-03 & & 4.30E-01 \\
\hline Pathway Totals & 8.70E-01 & & 2.90E-02 & & 9.03E-01 \\
\hline Residential, Seep SW7:-8 & $x^{2}+x^{2}+4$ & & $\therefore+\cdots$ & & $y$ \\
\hline $\mathrm{BE}$ & 1.10E-03 & & $2.70 \mathrm{E}-04$ & & 1.36E-03 \\
\hline Pathway Totals & 1.10E-03 & & $2.70 \mathrm{E}-04$ & & $1.36 \mathrm{E}-03$ \\
\hline \multicolumn{6}{|c|}{ Residential, SeepSW9-1 } \\
\hline$\overline{M N}$ & $1.80 \mathrm{E}-01$ & & 1.10E-02 & & 1.94E-01 \\
\hline CHLOROFORM & $1.40 \mathrm{E}-02$ & & 1.50E-03 & & 1.52E-02 \\
\hline Pathway Totals & 2.00E-01 & & 1.30E-02 & & 2.09E-01 \\
\hline \multicolumn{6}{|l|}{ Residential, Seep SW9-2 } \\
\hline$\overline{\mathrm{BA}}$ & 9.90E-02 & & $3.40 \mathrm{E}-03$ & & $1.02 \mathrm{E}-01$ \\
\hline $\mathrm{MN}$ & $1.30 E+00$ & & 7.80E-02 & & 1.36E+00 \\
\hline CHLOROFORM & 1.60E-03 & & 1.80E-04 & & 1.82E-03 \\
\hline Pathway Totals & $1.40 \mathrm{E}+00$ & & 8.10E-02 & & $1.46 \mathrm{E}+00$ \\
\hline \multirow{2}{*}{\multicolumn{6}{|c|}{$\begin{array}{l}\text { Residential, Seep W4TRIB } \\
\text { Pathway Totals } \\
\text { Residential Seep W4TRIB: }\end{array}$}} \\
\hline & & & & & \\
\hline$\frac{\text { Residential, Seep W4TRIB }}{\text { Pathway Totals }}$ & & & & & \\
\hline
\end{tabular}


Produce/

\begin{tabular}{|c|c|c|c|c|}
\hline Land Use/Site/Contaminant & Ingestion & Fish & Inhalation & Total HI \\
\hline Residential, Seep W4TRIB-11. & & & $\because \because$ & $\because$ \\
\hline AS & $5.00 \mathrm{E}-02$ & & $3.00 E-04$ & $5.05 \mathrm{E}-02$ \\
\hline$B A$ & $1.10 \mathrm{E}-01$ & & $3.90 E-03$ & 1.16E-01 \\
\hline$B E$ & $1.10 \mathrm{E}-03$ & & 2.70E-04 & 1.36E-03 \\
\hline$C D$ & 1.10E-01 & & 2.60E-02 & $1.34 E-01$ \\
\hline MN & $1.20 \mathrm{E}+00$ & & $7.50 E-02$ & $1.31 E+00$ \\
\hline MO & 1.70E-01 & & 1.10E-03 & $1.72 E-01$ \\
\hline Pathway Totals & $1.70 \mathrm{E}+00$ & & $1.10 \mathrm{E}-01$ & $1.78 \mathrm{E}+00$ \\
\hline \multicolumn{5}{|l|}{ Residential, Seep W4TRIB-12 } \\
\hline \multicolumn{5}{|l|}{ Pathway Totals } \\
\hline \multicolumn{5}{|l|}{ Residential, Seep.W4TRIB-2 } \\
\hline \multicolumn{5}{|l|}{ Pathway Totals } \\
\hline \multirow{2}{*}{\multicolumn{5}{|c|}{$\begin{array}{l}\text { Residential; Seep W4TRIB-3 } \\
\text { Pathway Totals }\end{array}$}} \\
\hline & & & & \\
\hline \multicolumn{5}{|l|}{ Residential, Seep W4TRIB-4 } \\
\hline \multicolumn{5}{|l|}{ Pathway Totals } \\
\hline \multicolumn{5}{|l|}{ Residential, Seep W4TRIB-5 } \\
\hline $\mathrm{MN}$ & $1.00 \mathrm{E}-01$ & & $6.40 \mathrm{E}-03$ & 1.11E-01 \\
\hline Pathway Totals & $1.00 \mathrm{E}-01$ & & $6.40 E-03$ & 1.11E-01 \\
\hline \multicolumn{5}{|l|}{ Residential, Seep W4TRIB-6 } \\
\hline \multicolumn{5}{|l|}{ Pathway Totals } \\
\hline \multicolumn{5}{|l|}{ Residential, Seep W4TRIB-7 } \\
\hline$B$ & $1.20 \mathrm{E}-01$ & & $3.40 \mathrm{E}-04$ & 1.25E-01 \\
\hline MN & $2.20 \mathrm{E}+00$ & & 1.30E-01 & $2.30 E+00$ \\
\hline Pathway Totals & $2.30 \mathrm{E}+00$ & & $1.30 \mathrm{E}-01$ & $2.42 E+00$ \\
\hline \multicolumn{5}{|l|}{ Residential, Seep W4TRIB-8 } \\
\hline \multicolumn{5}{|l|}{ Pathway Totals } \\
\hline \multicolumn{5}{|l|}{ Residential, Seep.W4TRIB-9 } \\
\hline \multicolumn{5}{|l|}{ Pathway Totals } \\
\hline \multicolumn{5}{|l|}{ Residential, Seep W6MS3 } \\
\hline \multicolumn{5}{|l|}{ Pathway Totals } \\
\hline \multicolumn{5}{|l|}{ Residential, Seep WAG4 MS1 } \\
\hline$\overline{B E}$ & $4.30 \mathrm{E}-03$ & & $1.00 \mathrm{E}-03$ & $5.29 E-03$ \\
\hline MN & $5.60 \mathrm{E}-01$ & & $3.40 E-02$ & 5.91E-01 \\
\hline Pathway Totals & $5.60 \mathrm{E}-01$ & & $3.50 \mathrm{E}-02$ & $5.97 E-01$ \\
\hline \multicolumn{5}{|l|}{ Residential, Seep WAG4 T2A } \\
\hline$\overline{\mathrm{BE}}$ & 2.70E-03 & & $6.60 E-04$ & $3.40 \mathrm{E}-03$ \\
\hline FLUORIDE & 4.60E-01 & & $1.10 E-03$ & 4.58E-01 \\
\hline MN & $1.20 E-01$ & & $7.50 \mathrm{E}-03$ & 1.31E-01 \\
\hline $\mathbf{v}$ & $9.20 \mathrm{E}-02$ & & 2.20E-02 & 1.14E-01 \\
\hline Pathway Totals & $6.70 \mathrm{E}-01$ & & $3.20 \mathrm{E}-02$ & $7.06 \mathrm{E}-01$ \\
\hline \multicolumn{5}{|c|}{ Residential, Seep WAG6 MS1 } \\
\hline $\mathrm{BE}$ & $3.30 \mathrm{E}-03$ & & $8.00 \mathrm{E}-04$ & $4.08 E-03$ \\
\hline MN & $2.30 E+00$ & & $1.40 E-01$ & $2.45 E+00$ \\
\hline V & 1.10E-01 & & 2.60E-02 & 1.33E-01 \\
\hline
\end{tabular}




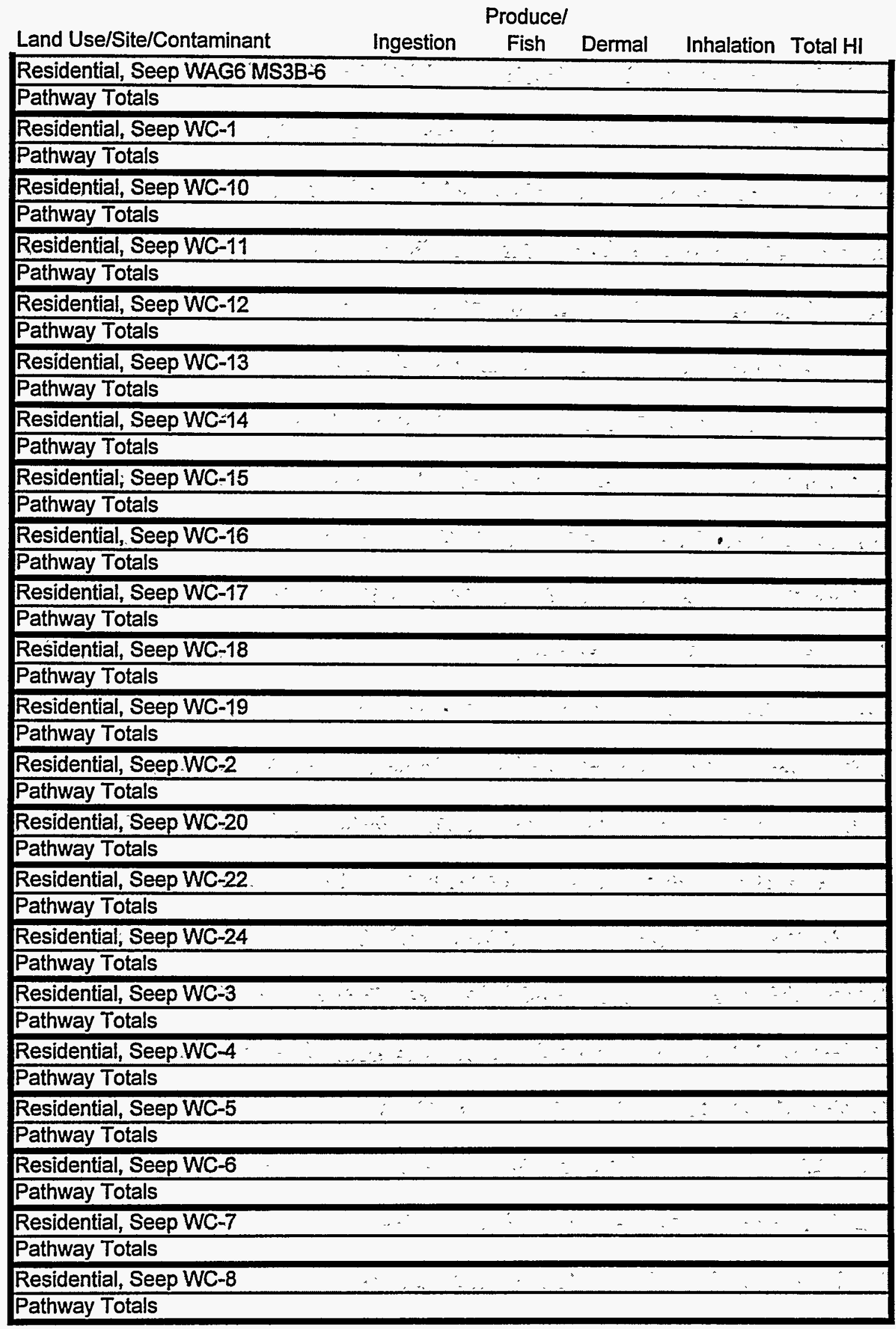




\begin{tabular}{|c|c|c|c|c|c|}
\hline Land Use/Site/Contaminant & Ingestion & $\begin{array}{c}\text { Produce/ } \\
\text { Fish }\end{array}$ & Dermal & Inhalation & Total HI \\
\hline \multirow{2}{*}{\multicolumn{6}{|c|}{$\begin{array}{l}\text { Residential Seep We } 9 \text { Sathway Totals } \\
\text { Pathen }\end{array}$}} \\
\hline & & & & & \\
\hline \multicolumn{6}{|l|}{ Residential, Seep WC7500 } \\
\hline $\mathrm{BE}$ & 2.70E-03 & & $6.60 \mathrm{E}-04$ & & $3.40 \mathrm{E}-03$ \\
\hline FLUORIDE & 4.60E-01 & & 1.10E-03 & & 4.58E-01 \\
\hline NITRATE & $1.40 \mathrm{E}-01$ & & $6.90 E-04$ & & 1.43E-01 \\
\hline CHLOROFORM & $5.50 \mathrm{E}-03$ & & $5.90 E-04$ & & 6.07E-03 \\
\hline Pathway Totals & $6.10 \mathrm{E}-01$ & & $3.10 \mathrm{E}-03$ & & 6.10E-01 \\
\hline \multicolumn{6}{|l|}{ Résidential, Seep WCHEAD } \\
\hline$\overline{B E}$ & $2.70 \mathrm{E}-03$ & & $6.60 \mathrm{E}-04$ & & $3.40 \mathrm{E}-03$ \\
\hline NITRATE & $1.30 E-01$ & & 6.50E-04 & & 1.34E-01 \\
\hline $\mathrm{V}$ & $1.00 \mathrm{E}-01$ & & 2.40E-02 & & $1.25 E-01$ \\
\hline Pathway Totals & $2.40 \mathrm{E}-01$ & & $2.60 E-02$ & & $2.63 \mathrm{E}-01$ \\
\hline \multicolumn{6}{|l|}{ Residential Seep WCTRIB-1: } \\
\hline$\overline{B E}$ & $2.70 \mathrm{E}-03$ & & $6.60 \mathrm{E}-04$ & & $3.40 \mathrm{E}-03$ \\
\hline MN & $6.50 \mathrm{E}-01$ & & 3.90E-02 & & $6.88 \mathrm{E}-01$ \\
\hline SB & 4.10E-01 & & 5.00E-02 & & 4.61E-01 \\
\hline Pathway Totals & $1.10 \mathrm{E}+00$ & & $9.00 \mathrm{E}-02$ & & $1.15 \mathrm{E}+00$ \\
\hline \multicolumn{6}{|l|}{ Residential, Seep WCTRIB-2 } \\
\hline+2 & $2.70 \mathrm{E}-03$ & & $6.60 \mathrm{E}-04$ & & $3.40 \mathrm{E}-03$ \\
\hline$\underline{V}$ & $9.90 \mathrm{E}-02$ & & 2.40E-02 & & $1.24 E-01$ \\
\hline Pathway Totals & $1.00 \mathrm{E}-01$ & & $2.50 \mathrm{E}-02$ & & 1.27E-01 \\
\hline \multicolumn{6}{|l|}{ Residential; Seep WGTRIB=3" } \\
\hline BE & $3.30 \mathrm{E}-03$ & & $8.00 E-04$ & & $4.08 \mathrm{E}-03$ \\
\hline FLUORIDE & $4.20 \mathrm{E}-01$ & & 1.10E-03 & & 4.26E-01 \\
\hline MN & 5.10E-01 & & 3.10E-02 & & 5.43E-01 \\
\hline V & 1.10E-01 & & 2.60E-02 & & 1.36E-01 \\
\hline Pathway Totals & $1.00 \mathrm{E}+00$ & & 5.90E-02 & & $1.11 \mathrm{E}+00$ \\
\hline \multicolumn{6}{|l|}{ Residential; Seep WCTRIB 4 ? } \\
\hline $\mathrm{BE}$ & $2.70 \mathrm{E}-03$ & & $6.60 \mathrm{E}-04$ & & $3.40 \mathrm{E}-03$ \\
\hline FLUORIDE & 1.30E-01 & & $3.20 E-04$ & & $1.28 \mathrm{E}-01$ \\
\hline MN & 4.00E-01 & & 2.40E-02 & & 4.23E-01 \\
\hline $\mathrm{V}$ & 1.10E-01 & & 2.70E-02 & & 1.39E-01 \\
\hline Pathway Totals & $6.40 \mathrm{E}-01$ & & $5.20 \mathrm{E}-02$ & & $6.93 \mathrm{E}-01$ \\
\hline \multicolumn{6}{|l|}{ Residential; Seep WCWEIR } \\
\hline AS & $1.80 \mathrm{E}-01$ & & 1.10E-03 & & 1.79E-01 \\
\hline$B E$ & $2.70 E-03$ & & $6.60 E-04$ & & $3.40 \mathrm{E}-03$ \\
\hline FLUORIDE & $3.40 E-01$ & & 8.50E-04 & & 3.40E-01 \\
\hline NITRATE & $1.30 E-01$ & . & 6.40E-04 & & 1.32E-01 \\
\hline SB & $1.50 E+00$ & & 1.90E-01 & & $1.72 E+00$ \\
\hline CHLOROFORM & $2.50 \mathrm{E}-03$ & & 2.70E-04 & & $2.73 \mathrm{E}-03$ \\
\hline Pathway Totals & $2.20 \mathrm{E}+00$ & & 1.90E-01 & & $2.38 E+00$ \\
\hline \multicolumn{6}{|l|}{ Residential, Seep WEST:SEEP } \\
\hline AS & $5.50 \mathrm{E}-02$ & & $3.20 \mathrm{E}-04$ & & $5.51 \mathrm{E}-02$ \\
\hline$B E$ & $2.20 \mathrm{E}-03$ & & 5.30E-04 & & 2.72E-03 \\
\hline MN & $4.20 \mathrm{E}+00$ & & 2.60E-01 & & $4.50 E+00$ \\
\hline
\end{tabular}




\begin{tabular}{|c|c|c|c|c|c|}
\hline Land Use/Site/Contaminant & Ingestion & $\begin{array}{l}\text { Jroduce/ } \\
\text { Fish }\end{array}$ & Dermal & Inhalation & Total HI \\
\hline NITRATE & $1.00 E-01$ & & $4.90 E-04$ & & $1.02 \mathrm{E}-01$ \\
\hline SB & 3.40E-01 & & 4.20E-02 & & 3.84E-01 \\
\hline Pathway Totals & $4.70 \mathrm{E}+00$ & & $3.00 \mathrm{E}-01$ & & $5.05 E+00$ \\
\hline \multicolumn{6}{|l|}{ Residential, Seep WOCET } \\
\hline$\overline{\mathrm{MN}}$ & 3.80E-01 & & $2.30 \mathrm{E}-02$ & & $4.04 \mathrm{E}-01$ \\
\hline Pathway Totals & $3.80 \mathrm{E}-01$ & & $2.30 E-02$ & & $4.04 \mathrm{E}-01$ \\
\hline Residential, Seep WOD & & & $\therefore$ & & \\
\hline$\overline{A S}$ & 5.50E-02 & & $3.20 \mathrm{E}-04$ & & 5.51E-02 \\
\hline$B E$ & 2.70E-03 & & $6.60 \mathrm{E}-04$ & & 3.40E-03 \\
\hline CR & 1.10E-01 & & 1.30E-02 & & 1.25E-01 \\
\hline FLUORIDE & $1.80 E-01$ & & 4.60E-04 & & 1.83E-01 \\
\hline MN & 1.00E-01 & & $6.10 \mathrm{E}-03$ & & 1.07E-01 \\
\hline CHLOROFORM & 1.10E-03 & & $1.20 E-04$ & & 1.21E-03 \\
\hline Pathway Totals & 4.50E-01 & & $2.10 \mathrm{E}-02$ & & 4.75E-01 \\
\hline \multicolumn{6}{|l|}{ Residential, Seep WS-1 } \\
\hline \multicolumn{6}{|l|}{ Pathway Totals } \\
\hline \multicolumn{6}{|l|}{ Residential, Seep WS-2 } \\
\hline \multicolumn{6}{|l|}{ Pathway Totals } \\
\hline \multirow{2}{*}{\multicolumn{6}{|c|}{$\frac{\text { Residential, Seep WS-3 }}{\text { Pathway Totals }}$}} \\
\hline & & & & & \\
\hline \multicolumn{6}{|l|}{ Residential, Seep WSTRIB-1 } \\
\hline$\overline{\mathrm{BE}}$ & $1.60 \mathrm{E}-03$ & & $4.00 E-04$ & & $2.04 \mathrm{E}-03$ \\
\hline MN & 2.60E-01 & & $1.60 \mathrm{E}-02$ & & 2.76E-01 \\
\hline SB & 4.10E-01 & & $5.00 \mathrm{E}-02$ & & 4.61E-01 \\
\hline Pathway Totals & $6.70 \mathrm{E}-01$ & & 6.60E-02 & & $7.39 \mathrm{E}-01$ \\
\hline
\end{tabular}


F-32 


\section{APPENDIX G}

SURFACE WATER RISK RESULT COMPARISON FOR ${ }^{90}$ Sr DATA WITH CHAIN-OF-CUSTODY PROBLEMS 

G-3

\begin{tabular}{|c|c|c|c|c|c|c|}
\hline Surface Water & \multicolumn{2}{|c|}{$\begin{array}{l}\text { Include COC Data } \\
\text { SR_90 Risk Total Risk }\end{array}$} & \multicolumn{2}{|c|}{\begin{tabular}{|l|} 
Exclude COC Data \\
SR_90 Risk Total Risk
\end{tabular}} & \multicolumn{2}{|c|}{$\begin{array}{l}\% \text { Difference (Exclude/lnclude) } \\
\text { Sr_90 Risk Total Risk }\end{array}$} \\
\hline $05 . S P 014$ & 7.20E-04 & $8.50 E-03$ & $7.20 E-04$ & 8.50E-03 & 100.0 & 100.0 \\
\hline 05.SP015 & 2.80E-0.4 & 5.50E-03 & 2.80E-04 & $5.50 \mathrm{E}-03$ & 100.0 & 100.0 \\
\hline 05.SP016 & $3.40 E-06$ & 5.70E-06 & 3.40E-06 & $5.70 E-06$ & 100.0 & 100.0 \\
\hline $05 . S P 017$ & 3.70E-03 & 1.30E-02 & 3.70E-03 & 1.30E-02 & 100.0 & 100.0 \\
\hline 05.SW001 & $3.50 E-05$ & $3.80 E-04$ & $3.50 E-05$ & $3.80 \mathrm{E}-04$ & 100.0 & 100.0 \\
\hline 05.SW0O2 & $2.90 \mathrm{E}-03$ & $3.00 \mathrm{E}-02$ & 2.90E-03 & $3.00 \mathrm{E}-02$ & 100.0 & 100.0 \\
\hline 05.SW003 & 5.60E-05 & $6.50 \mathrm{E}-05$ & 5.60E-05 & 6.50E-05 & 100.0 & 100.0 \\
\hline 05.SW004 & 1.60E-03 & 1.70E-03 & $1.60 \mathrm{E}-03$ & $1.70 E-03$ & 100.0 & 100.0 \\
\hline 05.SW005 & 4.00E-05 & 1.30E-04 & 4.00E-05 & 1.30E-04 & 100.0 & 100.0 \\
\hline 05.SW006 & 7.40E-04 & $3.10 E-03$ & $7.40 \mathrm{E}-04$ & $3.10 E-03$ & 100.0 & 100.0 \\
\hline $5 N N T$ & 2.10E-05 & 5.20E-05 & 2.10E-05 & 5.20E-05 & 100.0 & 100.0 \\
\hline $5 \mathrm{NST}$ & $9.00 \mathrm{E}-05$ & 2.60E-04 & $9.00 E-05$ & 2.60E-04 & 100.0 & 100.0 \\
\hline $5 N W-1$ & 2.10E-05 & 5.90E-05 & 2.10E-05 & $5.90 E-05$ & 100.0 & 100.0 \\
\hline $5 N W-2$ & 1.60E-05 & 1.20E-04 & $1.60 \mathrm{E}-05$ & $1.20 \mathrm{E}-04$ & 100.0 & 100.0 \\
\hline BTT & $2.70 E-02$ & $2.80 E-02$ & 3.00E-02 & $3.10 \mathrm{E}-02$ & 111.1 & 110.7 \\
\hline EAST SEEP & 4.60E-05 & 2.60E-04 & 8.00E-05 & $3.00 E-04$ & 173.9 & 115.4 \\
\hline FIFTH CREEK & 1.10E-04 & 1.30E-04 & 1.10E-04 & 1.30E-04 & 100.0 & 100.0 \\
\hline FIRST CREEK & $4.40 E-04$ & $4.50 E-04$ & $4.80 \mathrm{E}-04$ & 4.90E-04 & 109.1 & 108.9 \\
\hline FRENCH DR S & & 7.40E-04 & & 7.40E-04 & & 100.0 \\
\hline FRENCH DRAIN & 7.00E-06 & $1.00 E-02$ & 7.00E-06 & $1.00 \mathrm{E}-02$ & 100.0 & 100.0 \\
\hline HRT-10 & $4.30 E-04$ & 4.30E-04 & 4.30E-04 & 4.30E-04 & 100.0 & 100.0 \\
\hline HRT-1A & $1.50 E-03$ & 4.70E-03 & 1.30E-03 & 4.60E-03 & 86.7 & 97.9 \\
\hline HRT-1B & 8.80E-04 & 3.70E-03 & $9.40 E-04$ & $3.80 \mathrm{E}-03$ & 106.8 & 102.7 \\
\hline HRT-1C & $2.70 E-03$ & 8.10E-03 & 2.90E-03 & 8.30E-03 & 107.4 & 102.5 \\
\hline HRT-1D & $2.00 E-03$ & 1.30E-02 & 2.60E-03 & $1.30 E-02$ & 130.0 & 100.0 \\
\hline HRT-2 & 1.70E-03 & 4.90E-03 & $1.50 E-03$ & 4.70E-03 & 88.2 & 95.9 \\
\hline HRT-2A & 2.30E-03 & $5.00 \mathrm{E}-03$ & $1.20 \mathrm{E}-03$ & $3.90 \mathrm{E}-03$ & 52.2 & 78.0 \\
\hline HRT-3 & $1.50 E-03$ & 1.50E-03 & $1.40 \mathrm{E}-03$ & $1.40 \mathrm{E}-03$ & 93.3 & 93.3 \\
\hline HRT-4 & $1.50 E-03$ & $1.50 \mathrm{E}-03$ & 1.30E-03 & $1.30 E-03$ & 86.7 & 86.7 \\
\hline HRT-5 & 2.10E-03 & $2.10 E-03$ & $1.50 E-03$ & $1.50 E-03$ & 71.4 & 71.4 \\
\hline HRT-6 & $1.40 E-03$ & $1.40 \mathrm{E}-03$ & 1.10E-03 & 1.10E-03 & 78.6 & 78.6 \\
\hline HRT-7 & 9.20E-04 & $9.20 E-04$ & $9.20 E-04$ & $9.20 E-04$ & 100.0 & 100.0 \\
\hline HRT-8 & 5.20 E-03 & 5.20E-03 & 5.20E-03 & $5.20 \mathrm{E}-03$ & 100.0 & 100.0 \\
\hline HRT-9 & 2.30E-03 & $2.30 \mathrm{E}-03$ & 2.30E-03 & 2.30E-03 & 100.0 & 100.0 \\
\hline MB-1 & 1.10E-03 & $3.50 \mathrm{E}-03$ & 1.20E-03 & $3.50 \mathrm{E}-03$ & 109.1 & 100.0 \\
\hline MB-10 & 2.50E-04 & 8.50E-04 & 2.90E-04 & 8.90E-04 & 116.0 & 104.7 \\
\hline MB-11 & $3.70 E-04$ & $1.00 \mathrm{E}-03$ & $3.50 E-04$ & $9.90 E-04$ & 94.6 & 99.0 \\
\hline$M B-12$ & $3.40 \mathrm{E}-04$ & $1.00 \mathrm{E}-03$ & 3.00 E-04 & $9.50 E-04$ & 88.2 & 95.0 \\
\hline MB-13 & 1.20E-05 & 7.10E-05 & $1.20 \mathrm{E}-05$ & 7.10E-05 & 100.0 & 100.0 \\
\hline MB-14 & & 5.60E-05 & & $5.60 \mathrm{E}-05$ & & 100.0 \\
\hline MB-15 & 1.50E-05 & 1.50E-04 & $1.50 E-05$ & $1.50 \mathrm{E}-04$ & 100.0 & 100.0 \\
\hline MB-16 & 3.10E-05 & $1.00 E-04$ & $3.10 E-05$ & $1.00 E-04$ & 100.0 & 100.0 \\
\hline MB-17 & 2.30E-06 & $5.80 E-05$ & 2.30E-06 & $5.80 E-05$ & 100.0 & 100.0 \\
\hline MB-18 & 2.60E-05 & 1.20E-04 & 2.60E-05 & $1.20 \mathrm{E}-04$ & 100.0 & 100.0 \\
\hline MB-19 & 3.10E-05 & $3.60 E-05$ & 3.10E-05 & $3.60 \mathrm{E}-05$ & 100.0 & 100.0 \\
\hline$M B-1 A$ & $8.90 E-04$ & $3.10 \mathrm{E}-03$ & $1.00 E-03$ & $3.20 E-03$ & 112.4 & 103.2 \\
\hline MB-1B & 9.50E-04 & $2.70 \mathrm{E}-03$ & $6.80 \mathrm{E}-04$ & $2.40 \mathrm{E}-03$ & 71.6 & 88.9 \\
\hline MB-2 & 9.90E-04 & $3.20 \mathrm{E}-03$ & $7.00 \mathrm{E}-04$ & $2.90 E-03$ & 70.7 & 90.6 \\
\hline MB-3 & 8.40E-04 & 2.80E-03 & $9.50 \mathrm{E}-04$ & 2.90E-03 & 113.1 & 103.6 \\
\hline MB-3A & 1.10E-03 & 1.10E-03 & 1.10E-03 & $1.10 E-03$ & 100.0 & 100.0 \\
\hline MB-4 & 8.30E-04 & 3.00E-03 & $1.00 \mathrm{E}-03$ & $3.20 E-03$ & 120.5 & 106.7 \\
\hline MB-5 & $3.60 E-04$ & 2.70E-03 & $3.80 E-04$ & $2.70 E-03$ & 105.6 & 100.0 \\
\hline MB-6 & 3.00E-04 & 2.70E-03 & $3.00 E-04$ & $2.70 E-03$ & 100.0 & 100.0 \\
\hline MB-7 & 2.70E-04 & 2.30E-03 & 2.70E-04 & 2.30E-03 & 100.0 & 100.0 \\
\hline MB-7A SIDE & 2.90E-04 & 2.60E-03 & 2.90E-04 & 2.60E-03 & 100.0 & 100.0 \\
\hline MB-7B & 2.50E-04 & $1.50 E-03$ & 2.40E-04 & 1.50E-03 & 96.0 & 100.0 \\
\hline MB-8 & 2.60E-04 & $1.40 E-03$ & 2.50E-04 & $1.40 \mathrm{E}-03$ & 96.2 & 100.0 \\
\hline MB-9 & 2.40E-04 & 1.10E-03 & $2.60 \mathrm{E}-04$ & 1.10E-03 & 108.3 & 100.0 \\
\hline MBTRIB-1 & 2.60E-05 & 2.90E-05 & 2.60E-05 & 2.90E-05 & 100.0 & 100.0 \\
\hline
\end{tabular}


G-4 \begin{tabular}{l|l|l|l|l}
\cline { 2 - 5 } Surface Water & $\begin{array}{l}\text { Include COC Data } \\
\text { SR_90 Risk Total Risk }\end{array}$ & $\begin{array}{l}\text { Exclude COC Data } \\
\text { SR_90 Risk Total Risk }\end{array}$ & $\begin{array}{l}\text { \% Difference (Exclude/lnclu } \\
\text { Sr_90 Risk Total Risk }\end{array}$
\end{tabular}

\begin{tabular}{|c|c|c|c|c|c|c|}
\hline MBTRIB-2A & $4.00 \mathrm{E}-05$ & $1.80 E-04$ & $4.00 \mathrm{E}-05$ & $1.80 E-04$ & 100.0 & 100.0 \\
\hline MBTRIB-2B & $8.20 E-06$ & 1.10E-05 & 8.20E-06 & $1.10 E-05$ & 100.0 & 100.0 \\
\hline MBTRIB-3 & $8.90 E-05$ & $1.30 E-04$ & $6.70 \mathrm{E}-05$ & 1.00E-04 & 75.3 & 76.9 \\
\hline MBWEIR & $8.40 E-04$ & $3.00 E-03$ & $8.30 E-04$ & $3.00 E-03$ & 98.8 & 100.0 \\
\hline MID. DRAIN. & 2.40E-03 & $1.60 E-02$ & 2.40E-03 & 1.60E-02 & 100.0 & 100.0 \\
\hline MV-1 & 4.70E-05 & 9.10E-05 & & $4.40 E-05$ & & 48.4 \\
\hline NWTRIB & 6.10E-05 & 9.50E-05 & $9.40 E-05$ & 1.30E-04 & 154.1 & 136.8 \\
\hline$R-227$ & $1.10 E-04$ & $1.40 \mathrm{E}-04$ & $2.00 E-05$ & $4.50 E-05$ & 18.2 & 32.1 \\
\hline R-311 & $3.20 E-05$ & 5.30E-05 & $3.20 \mathrm{E}-05$ & 5.30E-05 & 100.0 & 100.0 \\
\hline RAC & 4.10E-05 & 4.40E-05 & 2.10E-06 & $5.50 E-06$ & 5.1 & 12.5 \\
\hline RS-1 & 2.10E-04 & 5.10E-04 & $2.20 E-04$ & $5.20 E-04$ & 104.8 & 102.0 \\
\hline RS-3 & 1.10E-03 & 2.00E-03 & 1.10E-03 & 2.00E-03 & 100.0 & 100.0 \\
\hline RS-3A & $1.30 E-03$ & 4.20E-03 & 1.10E-05 & $2.90 E-03$ & 0.8 & 69.0 \\
\hline RS-3B & 5.40E-05 & 2.90E-04 & 5.00E-05 & $2.80 E-04$ & 92.6 & 96.6 \\
\hline SPD & 7.40E-02 & $9.20 E-02$ & $7.40 E-02$ & $9.20 E-02$ & 100.0 & 100.0 \\
\hline SW2-1 & 4.30E-04 & 4.80E-04 & $4.30 \mathrm{E}-04$ & $4.80 E-04$ & 100.0 & 100.0 \\
\hline SW2-2 & 8.70E-04 & $9.20 E-04$ & 8.70E-04 & $9.20 E-04$ & 100.0 & 100.0 \\
\hline SW2-3 & $2.30 E-05$ & 6.70E-05 & $1.20 \mathrm{E}-05$ & 5.50E-05 & 52.2 & 82.1 \\
\hline SW2-4 & $4.20 \mathrm{E}-04$ & $2.60 \mathrm{E}-03$ & 3.70E-04 & $2.60 \mathrm{E}-03$ & 88.1 & 100.0 \\
\hline SW2-5 & 1.50E-01 & 1.70E-01 & $1.60 \mathrm{E}-01$ & $1.80 \mathrm{E}-01$ & 106.7 & 105.9 \\
\hline SW2-6 & 4.50E-01 & $4.50 \mathrm{E}-01$ & $4.50 \mathrm{E}-01$ & $4.50 E-01$ & 100.0 & 100.0 \\
\hline SW2-7 & 2.50E-01 & $2.50 E-01$ & $2.70 E-01$ & 2.70E-01 & 108.0 & 108.0 \\
\hline SW4-1 & 6.70E-03 & $9.50 \mathrm{E}-03$ & $6.70 \mathrm{E}-03$ & $9.50 E-03$ & 100.0 & 100.0 \\
\hline SW4-2 & 1.60E-02 & $1.90 E-02$ & $1.70 E-02$ & $2.00 \mathrm{E}-02$ & 106.3 & 105.3 \\
\hline SW5-1 & 1.30E-04 & 1.60E-03 & $1.30 E-04$ & $1.60 \mathrm{E}-03$ & 100.0 & 100.0 \\
\hline SW5-11 & 7.50E-01 & 7.90E-01 & 7.50E-01 & 7.90E-01 & 100.0 & 100.0 \\
\hline SW5-2 & $3.00 E-04$ & $6.20 \mathrm{E}-04$ & $3.10 \mathrm{E}-04$ & 6.30E-04 & 103.3 & 101.6 \\
\hline SW5-3 & 2.30E-03 & $1.90 E-02$ & 2.30E-03 & $1.90 E-02$ & 100.0 & 100.0 \\
\hline SW5-4 & 4.20E-01 & 4.20E-01 & 4.30E-01 & 4.30E-01 & 102.4 & 102.4 \\
\hline SW5-5 & 1.50E-03 & 2.20E-02 & $1.50 E-03$ & 2.20E-02 & 100.0 & 100.0 \\
\hline sw5-6 & 4.90E-02 & $6.70 E-02$ & 4.90E-02 & $6.70 \mathrm{E}-02$ & 100.0 & 100.0 \\
\hline SW5-7 & 5.50E-03 & $2.00 E-01$ & 5.50E-03 & 2.00E-01 & 100.0 & 100.0 \\
\hline SW5-8 & $3.50 E-04$ & $6.10 E-02$ & 3.50E-04 & $6.10 \mathrm{E}-02$ & 100.0 & 100.0 \\
\hline SW5-9 & 8.20E-04 & $6.90 \mathrm{E}-02$ & 8.20E-04 & $6.90 \mathrm{E}-02$ & 100.0 & 100.0 \\
\hline SW6-1 & 1.20E-05 & 4.30E-04 & $1.20 E-05$ & $4.30 E-04$ & 100.0 & 100.0 \\
\hline SW6-2 & & $2.90 E-03$ & & $2.90 E-03$ & & 100.0 \\
\hline SW7-1 & $8.20 E-05$ & $1.50 E-04$ & 5.20E-05 & $1.20 E-04$ & 63.4 & 80.0 \\
\hline SW7-2 & $3.40 E-05$ & $7.10 E-04$ & $4.70 E-05$ & 7.20E-04 & 138.2 & 101.4 \\
\hline SW7-3 & 8.00E-05 & 6.00E-03 & $7.40 E-05$ & $6.00 E-03$ & 92.5 & 100.0 \\
\hline sw7-4 & 5.90E-05 & 2.40E-04 & 5.90E-05 & 2.40E-04 & 100.0 & 100.0 \\
\hline SW7-5 & 2.30E-05 & $3.50 E-03$ & & $3.50 E-03$ & & 100.0 \\
\hline SW7-6 & $1.30 \mathrm{E}-03$ & $1.60 \mathrm{E}-03$ & $1.20 \mathrm{E}-03$ & $1.50 E-03$ & 92.3 & 93.8 \\
\hline SW7-7 & 5.60E-05 & $2.10 E-04$ & 5.60E-05 & 2.10E-04 & 100.0 & 100.0 \\
\hline SW7-8 & 4.10E-05 & $6.80 E-05$ & 2.30E-06 & 2.90E-05 & 5.6 & 42.6 \\
\hline SW9-1 & 1.00E-03 & 1.10E-03 & $1.20 E-03$ & $1.30 \mathrm{E}-03$ & 120.0 & 118.2 \\
\hline SW9-2 & 2.20E-04 & $2.20 \mathrm{E}-0.4$ & 2.40E-04 & $2.50 E-04$ & 109.1 & 113.6 \\
\hline W4TRIB-1 & $1.50 \mathrm{E}-02$ & 4.10E-02 & 1.60E-02 & 4.20E-02 & 106.7 & 102.4 \\
\hline W4TRIB-10 & $9.40 E-03$ & $3.90 \mathrm{E}-02$ & $1.00 E-02$ & 4.00E-02 & 106.4 & 102.6 \\
\hline W4TRIB-11 & 1.50E-02 & 4.80E-02 & $1.50 \mathrm{E}-02$ & $4.80 E-02$ & 100.0 & 100.0 \\
\hline W4TRIB-12 & 7.10E-03 & $7.40 \mathrm{E}-03$ & 7.80E-03 & 8.10E-03 & 109.9 & 109.5 \\
\hline W4TRIB-2 & $1.60 E-02$ & 4.30E-02 & $1.60 E-02$ & $4.30 \mathrm{E}-02$ & 100.0 & 100.0 \\
\hline W4TRIB-3 & 1.00 E-02 & $4.00 E-02$ & $1.10 \mathrm{E}-02$ & 4.10E-02 & 110.0 & 102.5 \\
\hline W4TRIB-4 & 9.70E-03 & 4.00E-02 & $1.00 E-02$ & $4.10 E-02$ & 103.1 & 102.5 \\
\hline W4TRIB-5 & 1.10E-02 & $3.00 \mathrm{E}-02$ & 1.10E-02 & 3.00E-02 & 100.0 & 100.0 \\
\hline W4TRIB-6 & $8.80 E-03$ & $4.50 E-02$ & $9.40 \mathrm{E}-03$ & 4.50E-02 & 106.8 & 100.0 \\
\hline W4TRIB-7 & 2.10E-02 & 7.10E-02 & 2.30E-02 & 7.30E-02 & 109.5 & 102.8 \\
\hline W4TRIB-8 & $8.60 E-03$ & $4.50 E-02$ & $9.20 \mathrm{E}-03$ & 4.50E-02 & 107.0 & 100.0 \\
\hline W4TRIB-9 & 8.60E-03 & $4.60 E-02$ & $9.50 \mathrm{E}-03$ & $4.70 \mathrm{E}-02$ & 110.5 & 102.2 \\
\hline W6MS3 & 3.30E-04 & 4.30E-03 & $3.30 \mathrm{E}-04$ & $4.30 E-03$ & 100.0 & 100.0 \\
\hline
\end{tabular}


G-5

\begin{tabular}{|c|c|c|c|c|c|c|}
\hline \multirow[b]{2}{*}{ Surface Water } & \multicolumn{2}{|c|}{ Include COC Data } & \multirow{2}{*}{\multicolumn{2}{|c|}{$\begin{array}{l}\text { Exclude COC Data } \\
\text { SR_90 Risk Total Risk }\end{array}$}} & \multicolumn{2}{|c|}{ \% Difference (Exclude//nclude) } \\
\hline & SR_90 Risk & Total Risk & & & Sr_90 Risk & Total Risk \\
\hline WAG4 MS1 & $1.20 \mathrm{E}-02$ & $3.30 \mathrm{E}-02$ & $1.30 \mathrm{E}-02$ & $3.40 \mathrm{E}-02$ & 108.3 & 103.0 \\
\hline WAG4 T2A & $9.50 \mathrm{E}-03$ & $2.60 \mathrm{E}-02$ & $9.40 \mathrm{E}-03$ & 2.60E-02 & 98.9 & 100.0 \\
\hline WAG6 MS1 & $7.70 E-05$ & $7.80 \mathrm{E}-04$ & 7.70E-05 & 7.80E-04 & 100.0 & 100.0 \\
\hline WAG6 MS1-1 & 2.60E-05 & $9.40 \mathrm{E}-04$ & $2.60 \mathrm{E}-05$ & $9.40 \mathrm{E}-04$ & 100.0 & 100.0 \\
\hline WAG6 MS2 & $8.40 E-05$ & 5.00E-03 & $1.60 \mathrm{E}-04$ & 5.10E-03 & 190.5 & 102.0 \\
\hline WAG6 MS3A & $1.60 \mathrm{E}-05$ & $3.80 \mathrm{E}-04$ & $1.60 \mathrm{E}-05$ & $3.80 \mathrm{E}-04$ & 100.0 & 100.0 \\
\hline WAG6 MS3A-1 & $3.10 E-05$ & $1.40 \mathrm{E}-04$ & 3.10E-05 & $1.40 \mathrm{E}-04$ & 100.0 & 100.0 \\
\hline WAG6 MS3A-2 & $1.20 \mathrm{E}-05$ & $1.50 \mathrm{E}-05$ & $1.20 E-05$ & 1.50E-05 & 100.0 & 100.0 \\
\hline WAG6 MS3A-3 & 3.10E-05 & 8.50E-04 & 3.10E-05 & 8.50E-04 & 100.0 & 100.0 \\
\hline WAG6 MS3B & $4.90 \mathrm{E}-04$ & $6.80 \mathrm{E}-03$ & $5.70 \mathrm{E}-04$ & $6.90 \mathrm{E}-03$ & 116.3 & 101.5 \\
\hline WAG6 MS3B-1 & $4.20 \mathrm{E}-04$ & $1.40 \mathrm{E}-02$ & $4.20 \mathrm{E}-04$ & $1.40 \mathrm{E}-02$ & 100.0 & 100.0 \\
\hline WAG6 MS3B-2 & $4.60 \mathrm{E}-04$ & $1.40 \mathrm{E}-02$ & 4.60E-04 & $1.40 \mathrm{E}-02$ & 100.0 & 100.0 \\
\hline WAG6 MS3B-3 & $1.80 E-04$ & 3.10E-03 & $1.80 \mathrm{E}-04$ & $3.10 \mathrm{E}-03$ & 100.0 & 100.0 \\
\hline WAG6 MS3B-4 & $4.40 E-04$ & 5.00E-04 & $4.40 E-04$ & $5.00 \mathrm{E}-04$ & 100.0 & 100.0 \\
\hline WAG6 MS3B-5 & $1.90 E-04$ & $2.40 \mathrm{E}-04$ & $1.90 E-04$ & $2.40 \mathrm{E}-0.4$ & 100.0 & 100.0 \\
\hline WAG6 MS3B-6 & 4.10E-04 & $6.20 \mathrm{E}-04$ & $4.10 E-04$ & $6.20 \mathrm{E}-04$ & 100.0 & 100.0 \\
\hline WC-1 & $4.30 \mathrm{E}-04$ & $7.90 E-04$ & 3.00E-04 & $6.60 \mathrm{E}-04$ & 69.8 & 83.5 \\
\hline WC-10 & $1.50 \mathrm{E}-04$ & $2.20 \mathrm{E}-04$ & $1.60 \mathrm{E}-04$ & $2.40 E-04$ & 106.7 & 109.1 \\
\hline WC-11 & $1.70 \mathrm{E}-04$ & $2.50 \mathrm{E}-04$ & $1.90 \mathrm{E}-04$ & $2.70 E-04$ & 111.8 & 108.0 \\
\hline WC-12 & $2.10 \mathrm{E}-04$ & 2.90E-04 & 2.30E-04 & $3.10 E-04$ & 109.5 & 106.9 \\
\hline WC-13 & $1.70 \mathrm{E}-04$ & $2.40 \mathrm{E}-04$ & 2.00E-04 & $2.70 \mathrm{E}-04$ & 117.6 & 112.5 \\
\hline WC-14 & $2.50 \mathrm{E}-04$ & $3.40 \mathrm{E}-04$ & $2.50 \mathrm{E}-04$ & $3.40 \mathrm{E}-04$ & 100.0 & 100.0 \\
\hline WC-15 & $2.30 \mathrm{E}-04$ & $2.70 \mathrm{E}-04$ & $2.30 \mathrm{E}-04$ & $2.70 \mathrm{E}-04$ & 100.0 & 100.0 \\
\hline WC-16 & $1.80 \mathrm{E}-04$ & $1.90 \mathrm{E}-04$ & $1.80 E-04$ & $1.90 \mathrm{E}-04$ & 100.0 & 100.0 \\
\hline WC-17 & $1.40 E-04$ & $1.60 \mathrm{E}-04$ & $1.60 \mathrm{E}-04$ & $1.80 E-04$ & 114.3 & 112.5 \\
\hline WC-18 & $2.10 \mathrm{E}-04$ & $2.10 E-04$ & 2.10E-04 & $2.10 \mathrm{E}-04$ & 100.0 & 100.0 \\
\hline WC-19 & $1.80 \mathrm{E}-04$ & $1.80 \mathrm{E}-04$ & 1.80E-04 & $1.80 E-04$ & 100.0 & 100.0 \\
\hline WC-2 & 2.40E-04 & $6.70 \mathrm{E}-04$ & $2.40 \mathrm{E}-04$ & $6.70 \mathrm{E}-04$ & 100.0 & 100.0 \\
\hline WC-20 & $1.50 \mathrm{E}-04$ & $2.90 \mathrm{E}-04$ & 2.30E-04 & $3.70 \mathrm{E}-04$ & 153.3 & 127.6 \\
\hline WC-24 & 2.30E-05 & 2.30E-05 & $2.80 \mathrm{E}-05$ & $2.80 \mathrm{E}-05$ & 121.7 & 121.7 \\
\hline WC-3 & $2.40 \mathrm{E}-04$ & $6.80 \mathrm{E}-04$ & 2.40E-04 & $6.80 \mathrm{E}-04$ & 100.0 & 100.0 \\
\hline WC-4 & $3.10 \mathrm{E}-04$ & $7.50 \mathrm{E}-04$ & 3.10E-04 & 7.50E-04 & 100.0 & 100.0 \\
\hline WC-5 & 2.70E-04 & $7.20 \mathrm{E}-04$ & $2.70 E-04$ & $7.20 E-04$ & 100.0 & 100.0 \\
\hline WC-6 & $2.80 E-04$ & $7.00 \mathrm{E}-04$ & $2.80 E-04$ & $7.00 \mathrm{E}-04$ & 100.0 & 100.0 \\
\hline WC-7 & $2.70 E-04$ & $7.20 E-04$ & 2.70E-04 & $7.20 E-04$ & 100.0 & 100.0 \\
\hline WC-8 & 2.30E-04 & $5.80 E-04$ & $2.40 E-04$ & $5.90 E-04$ & 104.3 & 101.7 \\
\hline WC-9 & $2.40 E-04$ & 4.90E-04 & 2.60E-04 & $5.10 \mathrm{E}-04$ & 108.3 & 104.1 \\
\hline WC7500 & 1.10E-04 & $2.50 E-04$ & $1.20 \mathrm{E}-04$ & 2.60E-04 & 109.1 & 104.0 \\
\hline WCHEAD & 4.10E-05 & 7.60E-05 & $1.20 \mathrm{E}-05$ & $4.70 \mathrm{E}-05$ & 29.3 & 61.8 \\
\hline WCTRIB-1 & $4.80 E-05$ & $1.30 E-04$ & $4.80 E-05$ & $1.30 E-04$ & 100.0 & 100.0 \\
\hline WCTRIB-2 & & $3.70 E-05$ & & $3.70 E-05$ & & 100.0 \\
\hline WCTRIB-3 & $1.90 \mathrm{E}-03$ & $2.40 \mathrm{E}-03$ & $1.90 \mathrm{E}-03$ & 2.30E-03 & 100.0 & 95.8 \\
\hline WCTRIB-4 & $6.70 \mathrm{E}-05$ & $1.10 E-04$ & $6.70 E-05$ & $1.10 E-04$ & 100.0 & 100.0 \\
\hline WCWEIR & $1.80 \mathrm{E}-04$ & $3.60 E-04$ & $2.00 \mathrm{E}-04$ & 3.70E-04 & 111.1 & 102.8 \\
\hline WEST SEEP & $1.90 \mathrm{E}-04$ & $3.20 \mathrm{E}-04$ & $1.90 \mathrm{E}-04$ & $3.20 \mathrm{E}-04$ & 100.0 & 100.0 \\
\hline WOCET & 2.80E-05 & $3.00 \mathrm{E}-05$ & & $2.00 E-06$ & & 6.7 \\
\hline WOD & $2.40 \mathrm{E}-04$ & $6.40 \mathrm{E}-04$ & $2.50 \mathrm{E}-04$ & $6.50 E-04$ & 104.2 & 101.6 \\
\hline WS-1 & $2.10 \mathrm{E}-04$ & 2.50E-04 & 2.30E-04 & $2.70 \mathrm{E}-04$ & 109.5 & 108.0 \\
\hline WS-2 & $6.60 \mathrm{E}-04$ & 7.60E-04 & 2.00E-04 & 2.90E-04 & 30.3 & 38.2 \\
\hline WS-3 & $2.70 \mathrm{E}-04$ & $2.90 E-04$ & $2.70 E-04$ & 2.90E-04 & 100.0 & 100.0 \\
\hline WSTRI & $2.70 E-04$ & $3.80 \mathrm{E}-04$ & $2.50 \mathrm{E}-04$ & $3.70 E-04$ & 92.6 & 97.4 \\
\hline
\end{tabular}


G-6 
ORNL/ER-368

\section{DISTRIBUTION}

1. A.Q. Armstrong

2. T.L. Ashwood

3. L.A. Asplund

4. J.J. Beauchamp

5. D.M. Borders

6. H.L. Boston

7. W.D. Brickeen

8. B.B. Burgoa

9. R.B. Clapp

10. M. Clauberg

11. A.H. Curtis

12. M.F.P. DeLozier

13. A.F. Diefendorf

14. C.J. Ford

15. S.B. Garland

16. D.S. Hicks

17. D.D. Huff

18. L.L. Kaiser

19. S.B. Kerr

20. R.H. Ketelle

21. E.A. Krispin

22. A.J. Kuhaida

23. D.M. Matteo

24. W.L. McCalla
25. D.E. McConnell

26. C.W. McGinn

27. P.L. Osborne

28. P.T. Owen

29. D.J. Pridmore

30-39. S.T. Purucker

40. D.E. Reichle

42. C.T. Rightmire

43. T.M. Scanlon

44. P.A. Schrandt

45. J.A. Shaakir-Ali

46. S.H. Stow

47. G.W. Suter

48. M.F. Tardiff

49. A.S. Will

50. Central Research Library

51. ER Document Management Center (U)

52. Office of Scientific and Technical Information, P.O. Box 62, Oak Ridge, TN 37831

53. G.D. Reed, University of Tennessee, Department of Civil and Environmental Engineering, 223 Perkins Hall, Knoxville, TN 37996-2010 